\title{
A Vision for Change AD Patel and the Politics of Fiji
}





\section{A Vision for Change AD Patel and the Politics of Fiji}

\section{BRIJ V LAL}

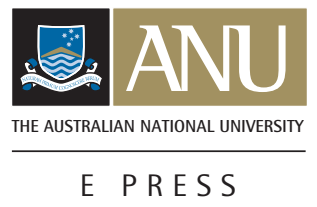




\section{ANU}

E PRESS

Published by ANU E Press

The Australian National University

Canberra ACT 0200, Australia

Email: anuepress@anu.edu.au

This title is also available online at: http://epress.anu.edu.au/

National Library of Australia Cataloguing-in-Publication entry

Author: $\quad$ Lal, Brij V.

Title: $\quad$ A vision for change : A.D. Patel and the politics of Fiji / Brij V Lal.

ISBN: $\quad 9781921666582$ (pbk.) ISBN: 9781921666599 (ebook)

Subjects: $\quad$ Patel, A. D. | q (Ambalal Dahyabhai), 1905-1969.

Fiji--Politics and government--20th century.

Fiji--History.

Dewey Number: 320.099611

All rights reserved. No part of this publication may be reproduced, stored in a retrieval system or transmitted in any form or by any means, electronic, mechanical, photocopying or otherwise, without the prior permission of the publisher.

Cover design and layout by ANU E Press

Printed by Griffin Press

This edition (C) 2011 ANU E Press 


\section{Contents}

Preface to this Edition $\ldots \ldots \ldots \ldots \ldots \ldots \ldots \ldots$ vii Prologue $\ldots \ldots \ldots \ldots \ldots \ldots \ldots \ldots \ldots \ldots \ldots$ ix

Chapter 1: Retrospect . . . . . . . . . . . 1

Chapter 2: Child of Gujarat. . . . . . . . . . . . . 17

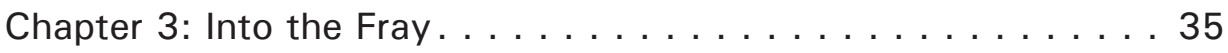

Chapter 4: Company and Kisan. . . . . . . . . . . . 57

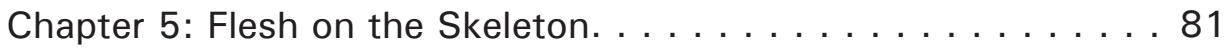

Chapter 6: Interregnum . . . . . . . . . . . 105

Chapter 7: Fire in the Cane Fields . . . . . . . . . . . . 129

Chapter 8: Towards Freedom . . . . . . . . . . . . . . 157

Chapter 9: Shaking the Foundations $\ldots \ldots \ldots \ldots 183$

Chapter 10: Independence Now . . . . . . . . . . . . . 213

Chapter 11: The End in Harness . . . . . . . . . . . . . 241

References. . . . . . . . . . . . . . . . . . 251

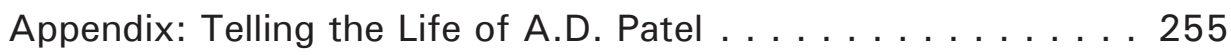

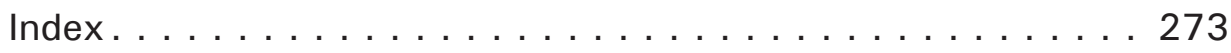





\section{Preface to this Edition}

This book was first published in 1997 after nearly a decade of interrupted research going back to the early 1980s. Minor emendations and corrections of a few errors pointed out by careful readers aside, I have resisted the temptation to revise the text substantially for several reasons. The text has a coherence and clarity of its own and any tinkering with it would not likely make much difference to its overall argument. One cannot write the same book twice, and re-writing texts wrenched out of the original context in which they were written, does not seem to me to be a particularly fruitful exercise. In any event, very little of substance has been published since on the period covered by this book to merit a re-evaluation of the original text. Ratu Sir Kamisese Mara, A.D. Patel's main political adversary for the last decade of life, published his memoirs soon after the publication of my own book, and more recently a biography of him has appeared. They offer predictable analyses and interpretations broadly anticipated in my book: Patel's obstinacy, stubborn - unwavering - commitment to deeply-held principles, the impossibility of even a limited introduction of common roll in Fiji, the proposition described by one colonial official as 'unrealistic at best, disruptive at worst.' Ten years after the book was published, I re-visited the original text and reflected on the methodological issues I had encountered and new sources I had since unearthed to assess if these might have made a material difference to the final outcome. It is included here as an Appendix. A collection of A.D. Patel's speeches and writings from the late 1920s to the late 1960s is being published simultaneously with this volume so that readers who so wish can evaluate my interpretation and analysis against the original documents. Also available now is a comprehensive collection of the most important documents from the Public Records Office at Kew Gardens, London, about the decolonisation of Fiji from 1960 to 1970. These documents throw considerable light on the official thinking in London and Suva about the critical issues facing the policy makers and the massive odds against which leaders such as A.D. Patel had to struggle. They should be compulsory reading for anyone seeking to understand the politics of the move towards Fijian independence and for the broad imperial background for this book. ${ }^{1}$

\footnotetext{
1 Additional sources: Ratu Kamisese Mara, The Pacific Way: A Memoir (Honolulu, 1997); Deryck Scarr, Tuimacilai: A Life of Ratu Sir Kamisese Mara (Adelaide, 2008), and Brij V Lal (ed.), Fiji: British Documents on the End of Empire (London, 2006), and A Vision for Change: Speeches and Writings of AD Patel (Canberra, 2011).
} 



\section{Prologue}

Men make their own history, but they do not make it just as they please. They do not make it under circumstances chosen by themselves, but under circumstances directly found, given or transmitted from the past. The tradition of all the dead generations weighs like a nightmare on the brain of the living.

Karl Marx

The Eighteenth Brumaire of Louis Bonaparte

He had been unwell for some time. Ever since suffering a mild heart attack in February 1968 while conducting a murder trial at Labasa on Vanua Levu, Ambalal Dahyabhai Patel had lived on borrowed time. But A.D., as he was known to the public, was not one to give in to intimations of his impending mortality. Much work was still left to be done, and he was determined to remain in harness to the last, much to the anguish of friends and colleagues who pleaded with him to slow down and delegate more responsibility to subordinates.

They pleaded in vain. This was the1960s, a decade of profound change in Fiji's political history, and Patel was at the centre of the changes, indeed, a principal moving force behind them. His uncompromising opposition to British colonial rule in Fiji, and his demand for independence based on democratic principles and non-racial franchise, forced the pace of constitutional change already tentatively under way as Great Britain sought to shed its remaining colonies in the Pacific and elsewhere. Fiji was granted its independence on 10 October 1970, 96 years after it became a colony of the British monarchy.

The demand for independence was not the only thing that preoccupied Patel in the 1960s. He was also at the centre of important developments in the colony's sugar industry. In 1969, after nearly two decades of persistence by cane farmers, the colonial government agreed to appoint an independent arbitrator, Britain's Master of the Rolls, Lord Denning, to decide the terms of a new contract between farmers and the Colonial Sugar Refining Company. As founder and leader of the Federation of Cane Growers, and the chief instigator of the British arbitration of the dispute, Patel naturally became the principal advocate of his group before the arbitration. This was to be his last fight with the CSR, he told his colleagues, prophetically as it turned out.

For farmers, the results of the arbitration could not have been better. Lord Denning was deeply impressed with Patel's plea on behalf of the farmers. Of all the advocates who appeared before him, including a future Chief Justice of the High Court of Australia (Sir Gerard Brennan), Denning wrote privately, Patel 
'was intellectually the most brilliant, as a character the most honourable, and as an advocate, the most persuasive. Quick in mind, fluent in speech, he stood out above all. ${ }^{1}$ It was Patel's 'persuasive advocacy,' said Denning, 'that led me to my report which was in favour of the growers and against the millers.' Denning's report led to the Company's withdrawal from Fiji in 1973, after nearly a century of economic dominance in a classic colonial setting.

The strain of a hectic public life took its toll on Patel, who suffered a heart attack on 3 September 1969. He was rushed to the Nadi hospital and the following day transferred to the better-equipped facility in Lautoka. There he remained for three weeks while doctors worked to determine the cause of his ailments, which included, besides diabetes from which he had suffered for nearly a decade, high fever and pneumonia. While recuperating, Patel kept himself informed of the arbitration proceedings concerning the sugar cane industry, received messages and continued to consult with colleagues about the confidential constitutional talks underway in Suva, concerning Fiji's impending independence.

Sir Derek Jakeway, the Governor, was sufficiently concerned about Patel's role in the political transition then underway to remind the ailing Patel of his crucial role in the political transformations that lay ahead. The Governor suggested that as a diversion Patel read Puisne Judge Ronald Knox-Mawer's book, Right Hand Court. The Chief Justice, Sir Clifford Hammett, an old and trusted friend, similarly asked Patel to 'rest and get well for [his] counsel and advice and wisdom and restraint [would] be in much demand in the coming year, and [he] must be fit to meet the demands that [would] be made on [his] physical resources.'2 Dr Charles Gurd, chief medical officer of the colony, and another longstanding friend, offered an optimistic prognosis, but urged Patel to take a long vacation and complete rest, preferably in a faraway place such as Hawaii. Forget about Fiji for a while, he urged.

Discharged from the hospital, Patel returned to his home in Nadi, where more tasks awaited him. He wrote soothing letters to his distraught children in England. He urged them to do well in their studies, and told them not to worry about his health. The centenary of Mahatma Gandhi's birth was in 1969, and Patel was invited, as he had often been on similar occasions in the past, to speak at a public celebration of the event at Suva's Old Town Hall. The Mahatma was Patel's idol, and he could not decline the invitation. His speech was a sombre reflection on the state of the world and an eloquent, touching tribute to the Mahatma. Despite all the progress made by modern science and technology, Patel wrote, man still lived in a state of moral and physical pollution, was still

1 This quote is from Lord Denning's letter to me, dated 20 January 1990.

2 From the private papers of A.D. Patel. Unless otherwise stated, all the unacknowledged quotes are from this source. 
unable to control his destiny: 'The machine,' Patel said, 'has become the master and man its slave.' The speech was entitled 'Hail Deliverer' and published posthumously in the local press. ${ }^{3}$

On 1 October, shortly after drafting this speech, Patel suffered a second heart attack and died that night, a tired and lonely man. He was 64 years old. As news of his death spread the next day, thousands of grieving men and women, most of them simple rural folk, streamed into Nadi from all parts of the country on foot, in trucks and hired cars and buses, clogging the dusty sugar town as rarely before. The last time Nadi had seen such a large number of people was during the height of the Pacific War. Shops, schools, and public offices closed as people poured in to pay tribute to the man whose body lay in state at the Nadi Civic Centre, a man who had symbolized their hopes, fears and aspirations for such a long time that many had come to regard him as an enduring fixture of their political lives. Four days later, as a crowd of some 15,000-20,000 people watched, many crying openly, Patel's body was cremated at Wailoaloa Cemetery. The funeral pyre was lit by his two young sons, Atul and Dhimant, who had flown to Fiji from England for the occasion.

His family was swamped with messages of condolence from the great and the humble alike. The Fiji Times, never a friend of Patel or of his party, now praised Patel's integrity and unwavering commitment to political principles he believed in. Patel would 'long be remembered as a national figure,' the newspaper said, albeit a 'controversial figure' whose 'impact on the land of his adoption was such that he will not be forgotten.' Ratu Sir Kamisese Mara, Chief Minister and leader of the Alliance Party, noted similarly that while there had been deep political differences between himself and Patel, the Federation leader 'had personal qualities deserving of the utmost respect,' among them 'sincerity', 'dedication' and 'devotion to the causes in which he believed.' Patel, Mara added, 'was an eloquent and forceful speaker skilled in parliamentary procedures,' a man who 'set a standard of dignity and courtesy worthy of the highest parliamentary traditions.'

Ratu David Toganivalu, a leading light in the Fijian Association, and something of a Fijian nationalist in the 1960s, expressed a similar sentiment. 'The political differences which divided us,' Toganivalu said of himself and Patel, 'cannot cloud our respect for him as a man of great ability who has played an important part in the development of political parties in Fiji and in the processes which led to the development of a political form of government.' Siddiq Koya, Patel's lieutenant and eventual successor, was equally fulsome in his praise. Patel had great courage and vision, Koya said, who saw clearly the changes that had to

3 It is included in the Appendix. 
come to Fiji. 'We are extremely fortunate that a man of his calibre elected to come to Fiji, and make his home here.' The public life of Fiji, Koya continued 'was considerably enriched by his contributions.'

Q.V.L. Weston, former District Commissioner Western and in 1969 the Chief Secretary of the Government of Nauru, wrote similarly of Patel, whom he had opposed on many occasions: 'A.D. was a fine man,' Weston observed, 'stubborn, sometimes too much for comfort;' but, he added, 'it was through his stubbornness that he got his way.' 'Mixed societies such as Fiji contain a lot of inborn prejudices, which get out of tune with the times and take leader of the quality and convictions of A.D. to shift.' When the tale is told by historians, Weston continued, 'it will be usually accepted that his way was right.'

This prophecy has not yet been fulfilled. Thus far, the verdict of written history of Fiji, with a few exceptions, has been variously unkind and uncharitable to Patel. It has generally portrayed him as an ambitious politician who cynically exploited the fears of ordinary Indo-Fijians for his own personal gains or for those of his cultural sub-community, the Gujarati. Some historians have even omitted his name from the gallery of those public figures who had a hand in achieving Fijian independence and shaping the course of late 20th century Fijian history. ${ }^{6}$ There was no mention of Patel's role in and contribution to the anti-colonial struggle in the official celebrations which accompanied independence in 1970. It was as if he had never existed, as if his name had to be extinguished from the pages of recent history to avoid embarrassment to those who had acquired power after a lifetime opposing independence.

This historical amnesia is not altogether surprising. Throughout his public life, Patel was an uncompromising — 'stubborn,' Weston said — advocate of social and political equality of all people within Fiji, and of democracy and independence for Fiji itself. Patel's vision and the political action its logic dictated, questioned the very foundations of colonial rule in Fiji and thus the role of every vested interest which sustained that rule. 'One Country, One Nation, One People' was the motto of the political party he founded. Political integration was his goal, while the foundations of colonial Fiji rested on the idea of racial compartmentalization and on the kinds of institutionalized political and social inequality that compartmentalization dictated. Because the foundations of independent Fiji were built essentially on the political structures and ideological premises bequeathed by the departing imperialist power, it is easy to see why Patel's place in the making of modern Fijian history has not been fully appreciated or even acknowledged.

4 National Federation Party Annual Convention Magazine, 1970.

5 From Weston's letter to S.B. Patel, 24 October 1969.

6 See Dr Ahmed Ali's Foreword in Scarr, 1984. 
Nonetheless, in the history of colonial Fiji, A.D. Patel stands with Ratu Sir Lala Sukuna as one of two outstanding figures who did much to shape the course of events at critical junctures in Fijian history. ${ }^{7}$ It has often been remarked that what Sukuna was to the Fijian people, Patel was to the Indo-Fijians. There is some truth in the comparison. The two men were more alike than appears at first glance. Both had cultivated intellects, magnetic personalities, style, strength of character, and unwavering commitment to strongly-held principles. In their vision of Fiji, however, they stood poles apart. Ratu Sukuna, an aristocratic chief, soldier, and loyal civil servant of the colonial government-indeed its chief authority on indigenous Fijian affairs - was essentially a traditionalist. That is, he saw in the colonial regime a means of preserving native Fijian hierarchies and thwarting the potential political influence of the Indian half of the population. Democracy, for Sukuna, meant unmitigated disaster for native Fijians, for whom, he believed, social, political or racial equality would mean the loss of control of Fiji to the Indians. Sukuna thought, on balance, British colonialism had therefore been and continued to be good for Fiji; it had certainly benefited the Fijian community. Colonialism, Sukuna said in 1934, 'gave us a common loyalty, and through a common loyalty it gave us unity. That great gift outweighs any faults there may have been in these sixty years of British rule.' That gift was not inconsiderable, the unification of previously fractious and warring groups competing for political supremacy in the islands under the overarching umbrella of British colonial rule with, as Sukuna saw it from his chiefly vantage point, minimal disturbance to the traditional way of life.

Patel disagreed completely. Though a patrician of privileged social background, Patel was an ardent champion of democracy, individual rights, and personal freedom. Colonialism and all it entailed - racial inequality, European superiority, petty discrimination — was for him an unmitigated evil that had to be eradicated whatever the cost. Its destruction was to him a prerequisite for the harmonious co-existence of the two main ethnic groups in Fiji. And he worked tirelessly toward that goal, to bring the two races together on the basis of equal and common universal franchise. There would be no peace in Fiji unless the two major communities learned to cooperate with each other across the racial divide. A nation was an 'imagined' community, Patel said to those who emphasized the primacy of primordial values of race and ethnicity. Nationalism 'is a question of the mind, it is not a question of the colour.' Fiji was covered with the ignorance of racialism and sectarianism. 'Remove the cover and the nation is there. ${ }^{8}$ On the economic front, as Gerard Brennan accurately recalled, Patel was 'passionately

7 Ratu Sukuna's life is captured in Scarr, 1980.

8 It is included in the Appendix. 
devoted to a change in the quality of life for the people of Fiji- a change which no doubt included economic improvement but which he extended beyond this to an assertion of what he regarded as human dignity. ${ }^{\prime 9}$

Patel's vision and political philosophy, as well as the manner in which he pursued them, continue to provoke controversy. His perceived vanity and stubbornness, as well as his personal charm, self-assurance, and political astuteness, still arouse debate. To begin with, there was his intellectual brilliance, of which Denning spoke, an almost uncanny ability to get to the heart of an issue before any of his contemporaries. Denning called Patel a 'great advocate,' while Chief Justice Sir Clifford Hammett recalled Patel as 'a born advocate of fluency and force [with] few to equal his persuasive skill at the bar.' In a rare departure from tradition, the full Supreme Court of Fiji paid its respect to Patel on 8 October: 'He was a model of what a counsel should be. He fought his cases hard; he fought them well; but throughout he was most courteous not only to the court but to his opponents and to everybody else associated with the case. ${ }^{10}$ Sir Kenneth Maddocks made a similar point in a private note to me: 'He struck me as very capable, quick-witted and experienced advocate, determined to press his case forcefully and inflexibly.' For Sir Kenneth, the emphasis was on inflexibility.

People who attacked him in public often praised him in private. Sir Malcolm Trustram Eve wrote disparagingly of Patel's conduct in the 1960 sugar cane strike but privately admired his tenacity and ability, and later became a friend. Patel, he said, had done the Middle Temple proud. Professor C.Y. Shepherd, who conducted an inquiry into the sugar industry in 1943, following a growers' strike led by Patel, made the obligatory public remarks about the selfish intentions of strike ringleaders, but in a confidential hand-written note to the Colonial Office, praised Patel's ability and urged his appointment to the Sugar Board whose creation he recommended in his report. ${ }^{11}$ The colonial government would not, and in the circumstances understandably could not, oblige. R.W. Robson, the conservative publisher of the Pacific Islands Monthly, and no friend of the IndoFijians, attacked Patel more bitterly than probably any other print journalist of his time, but privately he 'had learned to respect him for his ability and integrity' Andrew Deoki, the Suva lawyer-politician whom the Federation Party had defeated in the 1966 election, said that Patel had done more for the cane farmers 'than any other individual in Fiji. ${ }^{12}$ Sir Vijay R. Singh, who had fought many a battle with Patel, beginning with the sugar cane strike in 1960, recalled: 'Mr Patel was one of the most eloquent speakers of this country, and it was a

9 Brennan to R.D. Patel, 19 November, 1969.

10 Hammett to R.D. Patel, 2 October 1969.

11 Shepherd to Caine (Colonial Office), 31 August 1944 in Colonial Office File 69/2/12-1.

12 In Pacific Review, 9 October 1969. 
pleasure for me to hear him expound his views in his own persuasive inimitable style. We admired the eloquence, the clarity, and the occasional emotion as well as the ready wit that he brought to bear during debates.'13

Patel's brilliance is evident in the eloquence with which he articulated his social vision. Sir Robert Sanders wrote: 'From time to time I listened to him in the Legco [Legislative Council] where he could unfold a complicated case with scarcely a note and in a quiet and mannered way. I particularly remember the way he would put his head on one side and adopt an air of guilelessness as he made a telling point. ${ }^{\prime 4}$ Ratu William Toganivalu, himself no mean orator, and among the best on the Alliance benches, once said how he always listened carefully whenever Patel spoke in the Legislative Council, for he always learned something new. 'There is magic in his delivery,' Toganivalu recalled. If Patel were 'to put up a case to say that this roof was painted black', referring to the roof of the Legislative Council Chambers, 'they would believe him as I have often believed him.' ${ }^{15}$ It was a touching tribute. Patel had once admonished Toganivalu for raising the spectre of racial confrontation between Indians and Fijians, advising him to 'stop playing the part of Don Quixote, fighting windmills for the hand of fictitious Dulcinea.' Ratu Edward Cakobau spoke of Patel's 'inimitable and infectious persuasion.' ${ }^{16}$ Ratu Tiale Vuiyasawa, Fijian nominated member of the Legislative Council, said in August 1945, after listening to Patel on the thorny problem of land tenure: 'It was like listening to a speech made 30 or 40 years ago in the House of Commons when the late Lord Carson and the late Lord Oxford used to cross swords.' ${ }^{17}$

A tilt of the head, a strategic pause, an apt phrase, vivid imagery effortlessly invoked: these were elemental parts of Patel's rhetorical repertoire. Villagers, especially those in the cane belt, often travelled miles and waited hours to hear Patel explain his policies or to expose, clause by clause, deficiencies in the draft contracts offered by Colonial Sugar Refining Company. At these meetings, Siddiq Koya recalled in 1970, Patel 'would lend his own brand of humour, and keep us guessing till the last minute as to how he would put his message across.' When Patel spoke of the CSR as the tyrannical mother-in-law and the colonial government as its dutiful daughter-in-law, the Indian people understood him perfectly as they did when he dismissed government policies as solid, smooth, round and attractive but like a pumpkin hollow inside. His political opponents in the Indian Alliance or the Kisan Sangh he dismissed as crows among swans, trainee carpenters criticizing the architecture of the Taj Mahal (the policies of the Federation Party) or as mischief-making dhobi (launderers) of the Ramayana,

13 Ibid. Ratu George Cakobau's quotation which follows is also from this source.

14 Sir Robert Sanders, personal communication, 1 February 1990.

15 Legislative Council Debate, 8 May 1969.

16 Legislative Council Debate, 9 July 1969.

17 Legislative Council Debate, 31 August 1945. 
who attempted to soil Sita's reputation. King Canute and Kalidas, as well as Shakespeare and the Hindu scriptures, all provided grist for Patel's rhetorical mill. Patel believed in the power of reason and intellect. If he could argue his case with reason supported by facts, he could see no reason why people would not listen to him. Not everyone agreed. Ratu Mara, for one, believed that context and circumstances were just as important. As he said during the 1970 constitutional conference in London, 'We in Fiji are perhaps more sensible to atmosphere than subtle argument.'

Patel's message, whether at mass rallies or in private conversations with elite critics, was always the same. At the heart of his political philosophy was a repudiation of colonialism, and thus of the colonial state's image of itself as a benevolent, neutral entity, above politics, an impartial referee between competing ethnic groups and economic interests. The colonial state, Patel argued throughout his political life, was not the solution to Fiji's problems; it was instead the cause of those problems. Colonialism, Patel believed, was inherently racist, oppressive, divisive and elitist, the enemy of ordinary Fijians of all races in the colony. His criticism of colonialism remained undimmed despite the united opposition of most Fijians and Europeans and a section of his own community. His opposition to monopolies in sugar and gold mining industries, his support for localization of the civil service, for removal of racial and gender discrimination in public employment, a system of social security for the poor and the needy, and for the right of workers to strike or have recourse to compulsory arbitration - all these he pushed with vigour and unwavering conviction throughout his life. Patel was the first public figure in the country to advocate the use of 'Fijian' as a common name for all Fiji citizens. He died before many of his causes came to fruition (though they are being revived forty years later by the military regime in power in an undemocratic manner that would have been completely unacceptable to him).

Since the middle of the 20th century a healthy, though unequal, contest has raged between those with contrasting visions of Fiji. The one vision, represented by Ratu Sukuna, seeks sustenance in the traditional political order and the values that sustain that order. The other, personified by Patel, challenges traditional ways and the barriers of racial separation those traditional ways rested upon. After nearly two decades of tussle, the traditionalist, exclusionary vision emerged victorious, with the help of two military coups in 1987. A nation was torn apart, and a constitutional structure imposed by decree that effectively reinforced the pillars of ethnic separation, engendering feelings of ethnic exclusivity and chauvinism. The Indo-Fijian community was rendered politically impotent, forced to live on the sufferance of the taukei, the original 
owners of the land. For them, a new girmit appeared on the horizon, limited not to five years but one that might last the rest of their lives and into those of their children.

But history is not the privileged terrain of victors only. This book is an attempt to preserve the history of a failed effort to point Fiji in a different direction. What the outcome might have been had this failed effort succeeded is a matter best left to conjecture. The purpose here is not to speculate on what might have been. It is instead to tell the story of this failed effort. I have avoided the tendency to dwell on the sensational and the trivial. I have not discussed Patel's private life, as a man, as a father, as a husband. Such an approach would serve little purpose for this project. The principal focus here is on A.D. Patel as a public figure. In any case, I am not inclined to probe the private life of individuals. For me, the public actions of an individual are more important then the private thoughts which precede or inform them.

In this book, Patel speaks in his own voice, to explain his thoughts and his stance on issues. My editorial (and interpretive) intervention is indirect and limited. My interpretation of the history of Fiji in the 20th century and of the events in which Patel himself participated is in my book, Broken Waves: A History of the Fiji Islands in the Twentieth Century (1992). There the reader will also find the broad political context for the story related here as well as a guide to the historical sources used, some of which have a direct relevance to this text. This work is principally constructed from Patel's own speeches, letters and notes, archival material, interviews with people who knew Patel or are knowledgeable about the recent history of Fiji, and letters from senior colonial civil servants who worked with him. A fully documented text will be made available to anyone upon request. I have included in a companion volume a representative selection of Patel's main speeches and writings. It is a small selection, but it does help to illuminate Patel's vision and the eloquence with which he articulated it.

I never met Patel. He died when I was still in high school, but his name was legendary, even in remote, rural villages of Labasa. Our neighbour in Tabia, Mr Ram Dayal Singh, was nicknamed Patel, which was the name by which we all knew him. Years later when I asked why, I was told that it was because of Mr Singh's much-feared ability to dredge up obscure facts or make a telling point at village meetings to clinch an argument that he was named Patel, after A.D. Mr Singh was the only Patel I knew as a child. It was not until I began serious research into 20th century Fijian history in the 1980s that I encountered the man in the text. I admired Patel for his style and his intellect and the unwavering consistency and passionate conviction with which he articulated his vision. It is better for me to be upfront with my readers than to hide behind the façade of false objectivity and pretended detachment. 
A.D. Patel dared to dream an alternative future for this divided nation. He was a well-read man with refined sensibilities. He took stands on issues - on the common roll and in the sugar industry - and his refusal to compromise or acquiesce in the face of enormous pressure and in the most adverse of circumstances, commands respect. Patel was a man of foresight and vision, often far ahead of his time. In 1968, Patel argued that Fiji should become a republic with an elected Fijian head of state. Now, some 30 years later, that idea is gradually gaining ground. So, too, is the view that a common roll, with one person, one vote, one value, is the only way to build the foundations of a genuine, representative democracy in a multiracial society such as Fiji. He had talked about the need to provide social security to the needy in Fiji in the 1940s; it became a reality two decades later. The Fiji National Provident Fund was started when Patel was the Member for Social Services, as also was a countrywide library service. He had advocated the localization of the colonial civil service in the 1940s; the colonial government adopted localization as a policy in the 1960s. Patel had talked about the need for a university in Fiji in the 1950s; the University of the South Pacific was established in Fiji in the late 1960s. He had talked about an Agricultural Bank for the primary producers of Fiji, but that vision has not yet materialized. One can disagree with Patel on tactics and strategy, but on the fundamentals, even his staunchest opponents conceded, he was essentially correct. This book offers one perspective on the life of one man during an important period in Fiji's history. Inevitably, it is partial, a record of one person's views. For all that, it is a record well worth preserving.

Many people have assisted me in completing this project. First and foremost, I must thank members of A.D. Patel's family. They have been extraordinarily generous with their time, hospitality and friendship. Mrs Leela Patel gave me complete and unrestricted access to her husband's papers, and patiently answered sometimes intrusive questions about her husband's life and work. It is a great tribute to her that neither she nor any family member once said a word about what I might or might not write. For this complete freedom, I am more grateful, in particular, to Mrs Patel, Vasantika and Amita than I can say or they will ever know.

Scores of people in Fiji shared with me their impressions of Mr Patel. Among them were his great admirers as well as his bitter critics. In addition, a number of retired colonial officials, including a Governor (Sir Kenneth Maddocks), wrote to me about their impressions. I was particularly fortunate to have Lord Denning's personal appraisal of Patel's role in the 1969 arbitration. It would be invidious to list names of people who granted me interviews and supplied information; some of them in any case may wish to remain anonymous; but I must thank $\mathrm{Mr}$ R.D. Patel, A.D.'s brother, for filling me in on the family background, Mr Bal Govinda for material on the 1930s, Mr H.M. Lodhia, Mr Andrew Joseph and 
Mr M.K. Pillay for their personal reminiscences, the late Swami Rudrananda and Mr Karam Ramrakha for their taped recollections, and the late Ratu David Toganivalu, Mr Doug Brown and Sir Ronald Kermode for their insights into Fiji politics in the 1960s and Patel's role therein. The late Mr Setareki Tuinaceva and his staff at the National Archives, especially Matai Labaibure and the late Masud Khan, as well as Margaret Patel, have my thanks for granting me access to records in their custody. Tui and Masud were good friends and great professionals, and they will be missed by all users of the Fiji archives. Many cane farmers spent much time discussing the byzantine intricacies of sugar politics, providing rare insights into that industry as only they could. All these people and many more, I suspect, will have occasion to disagree with aspects of what I have written. That is inevitable, and probably as it should be. A.D. Patel was a controversial figure, and he would be surprised, disappointed even, at a unanimous verdict on him. But they all have my sincere thanks. I should add that they are in no way responsible for the use I have made of their insights and information. To Lila Lingam Moorti I am indebted for assistance in getting the manuscript ready for press.

Ganesh Chand, Aubrey Parke, Peter Read and Deryck Scarr read the manuscript with care and saved me from numerous embarrassing errors. Aubrey, who worked with A.D. Patel as his Secretary for Social Services in the mid-1960s, went through the entire manuscript painstakingly, line by line, and provided advice and made corrections which have helped the text. Idus Newby, my former colleague in the History Department at the University of Hawaii at Manoa, did his best to teach me how to write fluent English. I leave the success of his efforts for the readers to judge for themselves. At the production stages of this volume, Maree Tait at the Australian National University's National Centre for Development Studies was a much appreciated source of support and encouragement. Debra Grogan provided practical advice and help getting the manuscript to press and Tikka Wilson read the manuscript for consistency. Mr Jayanti Patel of Suva helped defray the cost of publication for which both the publishers and I are truly grateful. For this edition, I am grateful for the assistance of Sandra Davenport.

This book was written at various stages at the University of Hawaii at Manoa and the Australian National University. These two generous institutions, which have nurtured my scholarly efforts over the past two decades, have my eternal gratitude. In particular, I am indebted to my colleagues in the Division of Pacific and Asian History in the Research School of Pacific and Asian Studies and in the Department of History in the Faculty of Arts at the ANU for their unfailing good humour and encouragement. A special vinaka vakalevu and dhanyabad 
to Dorothy Macintosh, Jude Shanahan and Julie Gordon for their technical assistance and administrative support. Jude counselled me gently on how to handle my sometimes temperamental word processor.

I also wish to thank Mr Jai Ram Reddy, currently Fiji's Leader of the Opposition, and himself a successor to Mr Patel as the leader of the National Federation Party and consequently of the Indian community, who nominated me to serve on the Commission to Review the Fiji Constitution. This experience afforded me the opportunity, among many other memorable things, to observe the inner workings of Fiji politics, to assess peoples' fears and aspirations in an uniquely privileged way. The experience made me appreciate more keenly the battles that Patel had to fight, and which his successors and other democratic leaders are fighting now.

My last words of thanks are reserved for my peripatetic family, Padma, Yogi and Niraj, who have suffered long enough from my preoccupation-obsession they call it - with Fiji, and for putting up with the, alas, all too common occupational hazards of modern academic life: long periods of absence in the field and, more unforgivable, long bouts of grumpy absentmindedness at home. I readily plead guilty, with affection and gratitude; but they know as well as I do that, whatever happens, for the remaining years of my life, Fiji will be my spiritual home, my passionate obsession, my lifelong girmit, and always a haunting reminder of my own inescapable, existential in-betweenity.

Brij V. Lal, Suva, Fiji, 1996 


\section{Chapter 1: Retrospect}

We have the Indians here and we want to make the best of it. We are the Colony, not the Indians.

Sir Henry Marks, 1927

A.D. Patel arrived in Fiji on 11 October 1928. By then, Fiji had been a colony of Great Britain for exactly 54 years, its social, economic and political structures determined by a series of decisions taken in the last quarter of the 19th century. Patel and others like him would spend the next 40 years battling the system, trying to dismantle the foundations of a closed, racially compartmentalised colonial order. The task was fraught, for with the assistance of powerful entrenched interests in Fiji's plural society, the colonial government was often able to arrest or stifle any change that it did not authorise itself or which threatened the status quo.

For this purpose, it drew upon a large and well-tested arsenal of punitive tactics used by the colonial powers at different times throughout the world. These included, among others, the inculcation of fear, intimidation, arbitrary exercise of power, exile, divide and rule, and a variety of rewards for working within the system. In Fiji, as elsewhere, colonialism was ultimately about control, over people and over resources. To challenge the authority and legitimacy of the colonial order, then, was to undertake a daunting task fraught with potentially disastrous consequences. It was an unequal and unenviable contest; working within the system was more lucrative and rewarding than opposing it. This book is about the vision and work of one man, who also embodied the aspirations of many in his community and the country at large. In broad terms, this is the story of a counter-colonial project of the type mounted by nationalist leaders in former colonies of the European powers in Africa and Asia. In these places, the nationalist leaders triumphed, albeit after a period of long struggle, and were handed the reins of power when the imperialists departed. In Fiji, the nationalists and all those who opposed established ways of doing things were castigated and consigned to the margins. To understand the situation as it existed when A.D. Patel arrived in Fiji, it is necessary to look at the formative years of modern Fiji, both for background as well as for context.

The modern history of Fiji begins on 10 October 1874 when Fiji became a British Crown colony. ${ }^{1}$ This historic event itself was the culmination of a series of developments going back to the early years of the 19th century, when sustained

1 The literature here is vast, but the following provide a good guide to the literature: Derrick, 1951; Scarr, 1984; and Lal, 1992. 
contact with the European world first began. The first Europeans arrived in Fiji in 1800, sailors from the wrecked schooner, Argo. Shortly afterwards, they were followed by beachcombers and itinerant fortune seekers, traders in sandalwood and beche-de-mer, and missionaries, the first of whom, David Cross and William Cargill, arrived in the islands in 1835. By the 1860s, some 2,000 Europeans, mostly from Australia and New Zealand were living in various parts of the islands. Their presence and actions created tensions of their own. Predictable problems of law and order arose; some of the Europeans were engaged in the blood-stained labour traffic in the Pacific that aroused the wrath of the antislavery activists in England; while others were busily and often fraudulently acquiring choice pieces of fertile land in the islands.

These developments took place at a time of a great struggle for political supremacy among the leading matanitu (Fijian political confederations) in the islands. Pre-eminent among the 14 or so matanitu which existed in Fiji at the beginning of the 19th century were Bau, which was asserting its control over islands in the Koro sea, Rewa on the south-eastern coast of Viti Levu, Lakeba in the Lau group, and Bua and Macuata on the island of Vanua Levu. By the middle of the 19th century, after much intrigue and manoeuvring, Seru Cakobau of Bau emerged victorious, claiming for himself the title of Tui Viti, loosely translated as the 'King of Fiji.'

Unfortunately for him, this title conferred more problems than power, as Cakobau was held responsible for the consequences of events in the islands over which he himself had little personal control. Continued insistent demands by an intransigent European settler community for more land, a stable government and compensation for damages to settler property apparently caused by Fijians resenting their presence and demands, increased his vulnerability. After several attempts to form an indigenous island-wide government failed in the 1860s, Cakobau, with the encouragement of some Europeans, approached Great Britain with the offer of cession. 'If matters remain as they are,' said Seru Cakobau, 'Fiji will become like a piece of driftwood in the sea, and be picked up by the first passer-by...Of one thing I am assured, that if we do not cede Fiji, the white stalkers on the beach, the cormorants, will open their maws and swallow us.'2 So, choosing the only realistic course of action open to him, he ceded Fiji to Britain on 10 October 1874.

Sir Hercules Robinson, the Governor of New South Wales, received the instruments of Cession from the leading Fijian chiefs gathered at Navosa, Levuka, including Cakobau and Enele Ma'afu, the latter an emissary of the King of Tonga who had arrived in Fiji in 1848 to oversee the interests of the Tongan community settled in the Lau Group, and who had risen to a powerful

2 Derrick, 1951, 248. 
position in the islands. Through the Deed of Cession, which formalised transfer of the islands to British control, the chiefs hoped that they could rely on 'the justice and generosity' of Queen Victoria and her successors and that colonial rule would promote civilisation, Christianity, trade and good government in the islands, to use the language of the times. In return, Robinson promised to keep in mind the needs and interests of the Fijian chiefs and their people, and investigate all financial claims and obligations 'upon principles of justice and sound public policy.' In time, the Deed came to be seen as a potent symbol of a solemn charter between the Fijian people and the British Crown, and was invoked throughout the 20th century whenever questions of political and constitutional change were discussed.

Meanwhile, the Colonial Office had chosen Sir Arthur Hamilton Gordon as the first substantive governor of the nascent colony. The choice was significant and fra-reaching in its consequences, for more than any other individual, it was Gordon who formulated and implemented policies which laid the foundations of modern Fiji. Born in 1831, Gordon was the son of the fourth earl of Aberdeen, Sir Robert Peel's successor as the Prime Minister of England. He was, thus, well connected to the English political aristocracy, which gave him a remarkably free hand in running the colony. ${ }^{3}$ But Gordon was also a very ambitious man, eager from an early age to leave his mark upon the world. While still in his thirties, he was appointed Lieutenant Governor of the Canadian province of New Brunswick. From there, he went on to govern Trinidad and Mauritius, both tropical colonies with large Indian indentured populations working on the sugar plantations. This experience, combined with his social background and personal connections, influenced the direction of his work in Fiji.

Gordon arrived in Fiji in 1875 only to find a chaotic and potentially explosive situation. European settlers and speculators were laying claims to some of the best land in the colony and were clamouring for more and speedy resolution of the dispute in their favour. Capital was needed to develop the resources of the colony which Britain expected, indeed demanded, to become self-sustaining in quick time. Worst of all was the plight of the Fijian people themselves. They faced the danger of losing their lands to European settlers. On top of that, some 40,000 Fijians had recently died from an epidemic of measles accidentally introduced into the islands by a British man-of-war. To make matters worse, European experts influenced by the anthropologically-inspired evolutionary theory of human development fashionable in the latter half of the 19th century, confidently predicted an early extinction of the Fijian people, their society crumbling under the onslaught of a superior technological western civilisation. Only the fittest would survive, and that meant the Europeans.

3 For a biography of Sir Arthur Gordon, see Chapman, 1964. 
To solve these problems, Gordon promulgated a number of policies. ${ }^{4}$ Many of these are well known to the students of Fijian history, but they bear brief repetition for the general reader. To investigate European land claims and codify the indigenous forms of land tenure, Gordon appointed a land commission, which met over many years. Fijians provided ample evidence that there was no single, uniform pattern of land ownership applicable to all parts of Fiji; the variations were significant and apparently widespread, but Gordon decided to the contrary, decreeing that all land be held in inalienable right by the mataqali. As a result of this policy, eighty-three per cent of all land in Fiji remains in the hands of indigenous Fijians. With the transfer of previously Crown land into native land, the percentage in Fijian ownership is closer to ninety.

Gordon also acted expeditiously to shield the Fijians from the harmful exposure to outside influences. He prohibited the compulsory engagement of Fijian labour on European plantations. A system of native taxation was devised to enable Fijians to meet their tax obligations in kind rather than in cash, thus minimising disruption to village life. Fijian mobility was restricted, and a series of minute native regulations defined what a Fijian person could and could not do in the villages. Finally, a Council of Chiefs was created or rather formally recognised to advise the government on matters relating to Fijian welfare and development.

There is much debate among historians of Fiji about Gordon's Fijian policies. They have pointed out his many mistakes, his faulty understanding of Fijian society and its cultural patterns. ${ }^{5}$ Gordon believed he was recreating the true structure of Fijian society, whereas in truth, he was creating or blessing one which reflected and incorporated his own views and vision and current anthropological thinking. Fijian cultural practices and social institutions which offended western, Christian notions of private propriety and morality, for example, were quickly outlawed and their practitioners exiled to remote parts of Fiji or otherwise punished. Those who dared to question the framework and the foundations of colonial rule were similarly treated. Among them was the Fijian rebel Apolosi Nawai, a charismatic leader far ahead of his times, who championed - exploited in the eyes of his detractors - the cause of the ordinary Fijians and challenged them to stand up to their European exploiters. For his effrontery, he was exiled for long periods of his adult life to Rotuma, New Zealand and, towards the end, to the remote islands of the Koro Sea.

Nevertheless, when all is said and done, Gordon was an enlightened governor for his time; there were few like him then and since who made the survival and prosperity of an indigenous people the corner stone of their administration. It should be remembered that Gordon did not intend his policies to be set in stone.

4 For a study of Gordon's policies, see Legge, 1958.

5 See France, 1969. 
He believed that the Fijian people needed about 25 years in which to recover from the harmful effects of contact with the outside world and to stabilise their situation. Around the turn of this century, a re-examination of his policies did take place by a series of colonial Governors, including Sir George O'Brien, Sir Henry Jackson and Sir Everard im Thurn, but by then it was too late. Much had happened since Cession, and attitudes had hardened too far for there to be a genuine dialogue about reform. Within 25 years an innovative method of governance had become an encrusted orthodoxy tethered to a past increasingly at variance with the realities of the modern world and detrimental to the broader interests of the indigenous Fijian community itself.

To promote rapid economic development, Gordon realised early that he would have to look beyond the impecunious European settlers, themselves reeling from the collapse of the cotton boom following the end of the American Civil War. Gordon knew that the salvation of the colony lay in a large-scale plantation economy of the type he had seen in Mauritius and Trinidad. Sugar cane had shown potential as a viable commercial crop in earlier experiments in the islands, and he chose it. To develop and manage that industry, Gordon invited the Australian Colonial Sugar Refining Company (CSR). The Company arrived in Fiji in 1882 and remained there till 1973. For nearly a century, this colossus dominated the economic life of Fiji. A great part of Patel's life would be spent battling the CSR.

Plantation economy is labour intensive; but local labour was hard to come by. Fijians could not enlist for commercial employment except in exceptional circumstances and then only with official authorisation. In any case, the Fijian people saw no particular virtue in routine, back-breaking plantation work when subsistence agriculture and the life-style it encouraged addressed their basic needs. The Pacific Island labour trade, which had started in the 1860s, was expensive and too morally tainted to be relied upon to any significant degree. Even then it was doubtful whether it could meet the labour requirements Gordon had in mind. In the end, about 20,000 Melanesians were recruited from the Solomon Islands and the New Hebrides to work on the sugar cane and copra plantations. Some of their descendants continue to live in Fiji, a vulnerable, marginal minority on the fringes of society.

Gordon turned to India. The system of indentured emigration had been in existence since 1834. Mauritius was the first colony to import Indian indentured labour, followed a few years later by British colonies in the West Indies, notably Trinidad, British Guiana and to a lesser extent Jamaica. By the 1870s, hundreds of thousands of Indians from various parts of India, but principally from the North, had crossed the kala pani (the dark dreaded seas) to these distant places. By then, too, the administrative structure of the indenture system had been firmly established. 
Fiji had approached India with a proposal to import Indian labour in the 1860s, but the Indian government was unenthusiastic, lacking confidence in the ability of the makeshift Cakobau government to enforce the provisions of the proposed immigration legislation. That obstacle was removed when Fiji became a British Crown Colony in 1874. The Government of India sanctioned the emigration of its subjects on the broad understanding that its subjects who settled in the colonies would enjoy social and political rights equal to those of their fellow subjects. This view was most expressly stated in the now famous Lord Salisbury's Despatch in March 1875, where it was said:

Above all things we must confidently expect, as an indispensable condition of the proposed arrangements, that the Colonial laws and their administration will be such that Indian settlers who have completed the terms of service to which they agreed, as the return for the expense of bringing them to the Colonies, will be in all respects free men, with privileges no whit inferior to those of any other class of Her Majesty's subjects resident in the Colonies. ${ }^{6}$

This document was frequently cited by Indo-Fijian leaders as having the same significance and import for the protection of Indian rights in Fiji as the Deed was for the protection of Fijian rights. Critics argue that the Despatch could not have the same legal or moral force as the Deed, for, among other things, it did not mention Fiji specifically. In any case, they say, since the 'indispensable condition of the proposed arrangements,' the Indian Government's more active involvement in the encouragement of colonial emigration, was rejected by the various Indian provinces and by the Government of India itself, the despatch cannot have much legal authority.

In matters of high policy, minor technical quibbles can be a dangerous thing. Since the beginning of Indian indentured migration to Fiji, the Government of India constantly reiterated the equality of Indian settlers in Fiji, and elsewhere, with other colonial residents. The labour-starved colonial government of Fiji accepted this principle, which for the Government of India was the precondition for continued Indian emigration. India's position is quite evident from the words of the Crewe Commission which investigated the situation of Indians living in the colonies in 1910 .

Writing specifically about Fiji, the Commission said:

The present administration itself fully recognises the value of the Indians as permanent settlers and is willing to concede them the enjoyment of equal civil rights. The whole tenor of the correspondence between India and the colony shows that it was on this condition that

6 The full text of this document is in the National Archives of Fiji; a copy is in my possession. 
indentured immigration in Fiji has been allowed in the past, and any measures leading towards lowering the political status of the immigrants or reducing their economic freedom would, in our opinion, involve a breach of faith with those affected. ${ }^{7}$

The comparison between the Despatch and the Deed of Cession is interesting. The words most commonly associated with the Deed, the maintenance of the 'paramountcy of Fijian interests,' are not mentioned once in the document. The general sentiment was that, all things considered, the rights of the Fijian people 'shall be recognised so far as is and shall be consistent with British Sovereignty and Colonial form of government,' just as the general sentiment of political equality lay behind Salisbury's Despatch. It is a point of some importance which is not frequently appreciated in Fiji.

The first group of 498 Indian indentured labourers arrived in Fiji aboard the Leonidas on 14 May 1879. Although at first unwelcome to European planters, who resented Gordon's Fijian labour policies and hoped for cheaper labourers from nearby sources, the new immigrants soon proved themselves to be reliable and productive workers, and their industry quickly dispelled the planters' reservations. ${ }^{8}$ And so, a steady flow of Indian labour began. Altogether 60,000 Indian men, women and children came to Fiji between 1879 and 1916, when indentured emigration was finally abolished. They were a part of over one million indentured migrants who had left India for the colonies in the late 19th and early 20th centuries.

The indentured labourers came on a five year agreement - a long and apparently complicated word which was shortened to girmit by the illiterate peasantswhich stipulated the conditions of their employment: they would be expected to do work related to the cultivation and manufacture of crops; on weekdays they would work for nine hours and five on Saturdays, Sundays and holidays being free; adult males would earn one shilling per day and women nine pennies; they would have free medical care and accommodation in the 'lines', as living quarters on the estates were called, small, congested rooms that provided little space for privacy and even less for social and cultural recreation, and rations for the first five months on a scale stipulated by the government of four pennies per day for each adult over the age of 12; and finally, the immigrants would be entitled to a free return passage back to India at the end of ten years of residence in the colony; they could, of course, return after five, but at their own expense.

By the standards of the 19th century, the contract could be seen as, and indeed was, a remarkable document, especially when the very notion of a contract between an employer and an employee was something unheard of. However,

7 From the passage (no. 358) of the report cited in a debate in the Legislative Council, 1965.

8 Lal, 1982, Chapter 8, 55-69. Generally, Gillion, 1962. 
more important than what was in the agreement was what was left out of it. The indentured workers did not know, for instance, that they would have no voice in the choice of their employers, and once allocated to one, they could not obtain a transfer to another employer except in the most exceptional of circumstances, such as gross abuse of contract or 'illegal' violence. They were not told that their mobility would be curtailed by law: the labourers could not leave their plantations for any reason without the overseers' permission. They could not easily or voluntarily withdraw from their contracts no matter how compelling the reason. Many immigrants did not know that the option of time work in the fields had been replaced by task work, which was often set on the basis of what the most able-bodied men could accomplish in a specified period of time and not what ordinary labourers could accomplish in a normal working day. Very few, if any, of them knew of the numerous penalties for breach of labour regulations, punishment for negligence, non-completion of tasks, defiance of those in authority, and the like. And it was not until the early years of this century, two decades after indenture began, that the girmitiyas (indentured labourers) were able to earn the amount of wages stipulated on their contract. It was a trap that few were able to escape.

Of Fiji's indentured migrants, 45,000 came from North India, the overwhelming majority from the United Provinces, now known as Uttar Pradesh. ${ }^{9}$ Within that province, the majority came from the poor, depressed eastern (poorbea) districts, such as Basti, Gonda, Faizabad, Azamgarh, Sultanpur, Ballia and Ghazipur. Droughts and famines were regular visitors to these areas. Opportunities for employment were few. Many people were in the clutches of money lenders. Fragmentation of landholding following the practice of primogeniture had created its own problems. Not surprisingly, then, by the middle of the 19th century, emigration had become a way of coping with the vicissitude of life in the economically depressed villages of the Indo-Gangetic plains. People from the United Provinces were migrating in large numbers to the industrial centres of Calcutta, to the Assam tea gardens, the Bihar coal mines and the Bombay textile mills, the flow increased by the availability of accessible rail transportation. By the turn of the century, noted the Census Commissioner Edward Blunt, 'there is not a single family in the Benares Division which has not at least one member in the Provinces of Bengal, Assam, Bihar and Orissa. ${ }^{10}$

It was from this already uprooted, migration-prone mass of humanity that the immigrants to Fiji came, encouraged, no doubt, by tall tales the recruiters told of easy fortune awaiting them in the colony. A very large number of recruits had already migrated within India in search of employment when they were recruited for Fiji. Most were recruited in large cities such as Benares, Lucknow,

9 This is based on my book, Lal, 1983.

10 Census of India, Vol. XVI, Part 1 (1911), 49 
Agra and Delhi. When the northern sources began to dry up, the recruiters turned to South India, from where some 15,000 indentured immigrants were recruited after 1903. The principal districts of labour recruitment in the South were Tanjore, Trichnopoly, Arcot, Madras and Vizagapatnam.

The agreement under which the indentured labourers came provided for a passage back to India after a period of ten years of 'industrial residence' in the colony; they could return at their own expense after five. Most of the migrants had probably intended their excursion out of India as a brief sojourn, a temporary expedient to cope with some personal misfortune or economic hardship; it seems unlikely that many would have consciously opted for a permanent break with their kith and kin in the villages. Quite a few did return, but the majority remained behind, enticed by the prospect and the reality of better opportunities, official discouragement of repatriation, inertia and the dread of undertaking a long sea voyage again, and settled permanently in Fiji, principally in the sugar cane belt where their descendants still live.

To facilitate a stable family life and, hopefully, to create a dependable pool of local labour supply, the Government of India insisted on a certain number of women accompanying men to the colonies, the ratio set at 40 women to every 100 men on every voyage. In Fiji's case, that ratio was always met, though it did not always succeed in producing the intended results. Although the majority of the immigrants came as single individuals, some 4,000 families emigrated as well. These were not all marriages of convenience formed at the direction of the recruiting officer to facilitate the passage of single (and especially single female) migrants through the emigration depot, as has sometimes been alleged. The bulk of the families consisted of couples who had left their homes together. The grave disparity in sex ratio created severe problems on the plantations, contributing to unstable family life, encouraging sexual trafficking and leading to physical violence and suicide. It was a very long time before a semblance of normalcy returned in family and domestic arrangements in the Fiji Indian community.

Many Europeans, both colonial officials and settlers, who opposed the Indians' demand for social and political equality, continually sought to put the Indians in their place by reminding them of their forebears' supposed lowly social origins. 'Dregs of Indian society,' 'riff-raff picked up from the streets of Calcutta,' were only some of the unkind epithets used to describe the newcomers. Such denigration is not surprising, for it provided an essential ideological underpinning for the European-dominated colonial order. To accord the girmitiyas a measure of humanity, to see them as something other than beasts of burden, units of labour to be exploited for profit, would have been morally problematic. The truth, however, was that the social origins of the indentured immigrants reflected the social and demographic composition of rural India. Altogether, some 300 castes were represented in the emigrating population, the majority naturally 
enough coming from those adversely affected by the deteriorating economic circumstances of the late 19th century. These included small cultivators (Kurmi, Kori), artisans (Kumhar) and landless labourers (Chamar), as well as higher caste agriculturalists (Brahmin, Thakur).

Whatever their social and caste background, the girmitiyas were all coolies in the eyes of their plantation employers and overseers. Work in the field was allocated according to the dictates of production quotas and not on the basis of caste. Neither was compensation based on the recognition of social hierarchy among the workers. The plantation was a great leveller of hierarchy among the workers. The indentured workers had a daily routine to follow: up at the crack of dawn when the mill whistle went off, preparing food for a hurried breakfast and lunch, sharpening tools and then off to the fields or to the mills. The whole day was spent at work, weeding crops, hoeing, cleaning drains, ploughing and harrowing, harvesting. Late in the afternoons, they returned to their lines.

In the 1880s and 1890s, when conditions in the Colony were particularly bad, workers could complete only two thirds of the tasks set, but received little or no credit for the amount of work they had accomplished. The government argued that it was a well known proposition that if a person engages to perform a given task or a piece of work for a given wage and fails to perform such a task, he forfeits all claim to the wage: for the performance of the task is the condition precedent to the payment of the wage.'11 That view seems reasonable on paper, except that it left unanswered the larger question: why was it that the overwhelming majority of the labourers were unable to complete their allotted tasks in the first place? The labourers could, of course, take their employers to court, but there the magistrates invariably decided in favour of the weight of documentary evidence the employers were able to bring. The letter, not the spirit, of the law triumphed in the court room. Consequently, few labourers laid complaints against their employers, not because of indifference or lethargy, but because of fear, threat of retribution, ignorance of the law and, after all the risks had been taken, the dismal conviction rate of the employers. ${ }^{12}$

Narak (hell) is what the Indians generally called their girmit experience. They recalled the relentless pace of work, severe punishments for breaches of labour regulations, poverty, and moral and cultural disorientation. Life for the labourers was particularly hard in the 1890s, when the workers were completely at the mercy of their employers, and the colonial government, facing financial difficulties and preoccupied with problems relating to Fijian society, failed to protect the rights of the workers. After the turn of the century, housing improved as did enforcement of labour regulations with the appointment of

11 Lal, 1995.

12 For details, see Lal, 1986. 
resident inspectors of immigrants in the major areas of Indian settlement. However, residual bitterness at the government's general indifference towards their welfare remained with the Indian people long after indenture had ended.

By the early years of the 20th century, the plight of Indians in Fiji was beginning to attract the attention of sympathetic outsiders, such as the Methodist missionaries J.W. Burton and Florence Garnham, and even the leaders of Indian public opinion. C.F. Andrews visited Fiji in 1915 and 1917 at Mahatma Gandhi's urging, and wrote critically about social and moral conditions on plantations. The high rate of suicide among migrants attracted special attention, but it was the plight of women and their reported abuse by overseers, that caught and enraged public opinion in India. ${ }^{13}$ The Viceroy, Lord Hardinge, was shocked to learn that indentured women in the sordid lines had to 'serve' several men in the lines, and moved to abolish the system of indenture forthwith in 1916. By then, indenture was increasingly seen by a nationally re-awakening India as a badge of moral dishonour, a stark reminder of its subordinate national stature in the eyes of the world community. Fiji protested at the certain ruin that the abolition of indenture would cause to its sugar-dependent economy. Reports of abuse were exaggerated, it said; in any case, many reforms had already been implemented in response to the complaints, and more progressive reforms were in prospect. It requested the Colonial Office to plead its cause with the Indian government and sent its own private delegations to the subcontinent to do the same, but the Government of India remained unmoved. The shipping of indentured labourers ceased in 1916, and all indentures were cancelled on 1 January 1920.

Whether girmit was narak or slavery is a matter of debate and perspective. For many Indians, indenture was a period of great physical and social hardship. Others, especially those in positions of power as sirdars (foremen), did relatively well for themselves. Indenture was servitude not for a lifetime but a limited sentence of five years, after which the migrants could move out and take their fate in their own hands. Most did. Those who re-indentured did so because they lacked other alternatives. Girmit left an indelible mark on the lives of all those who lived through it. All the familiar markers of the old world gradually disappeared; Caste diminished in importance as a determinant of social position or economic status. Marriages inevitably cut across caste, cultural and even religious boundaries. And the girmitiyas were more alone in the world, dependent for success on their own initiative and endurance. Neither community nor extended kinship network could be relied upon automatically for support in times of need. As a result, they were - they had to become-more assertive in industry and politics.

13 See Lal, 1985. 
By 1901, Indians numbered 17,105 in a total colonial population of 120,124. Many of them were still under indenture, but the proportion of the ex-indentured population was steadily growing, with all the attendant consequences. In 1921, Indian population totalled 60,634 out of the total colonial population of 157,266, and by 1936, 85,002 out of 120,414. The sex ratio in the Indian community became less disproportionate. Another important demographic trend in the Indian community was the gradual dwarfing of the India-born with the Fijiborn. By 1921, for example, 44 per cent of the Indians in Fiji were born in the colony. We shall consider the consequences of these trends later.

Most of the early free Indians settled either in the cane growing areas or on its fringes and depended for their livelihood upon it. Rewa and Navua in southeastern Viti Levu were the earliest centres of Indian settlement, and much of the early leadership of the community came from this region. However, as other areas opened up to cane cultivation and Indian settlement, their demographic and political significance declined. As time passed, western Viti Levu and parts of Vanua Levu, the principal cane growing areas of Fiji, became the main areas of Indian settlement. Some people experimented with other occupations, but limited opportunities, family obligations, kinship ties and lack of education and marketable skills, forced most to depend on agriculture, principally sugar cane and rice cultivation. The free settlers co-operated on projects requiring reciprocal exchange of labour such as building and maintaining places of worship and instruction and roads, planting and harvesting crops. They devised or recreated their own mechanisms for regulating behaviour or enforcing conformity to the norms of the society they were establishing, often from a fractured and remembered past. Official indifference to the cultural and spiritual needs of the community helped to promote a semblance of unity and social cohesion among the early settlers.

From the very early days of indenture, Indian parents realised the importance of education both for cultural survival as well as for escaping from the vicious cycle of poverty and servitude that was their lot at the time. Their keenness helped form organisations such as the Arya Samaj, which took a lead in social and religious matters in the colony, to start schools in the main centres of Indian settlement in Viti Levu. Other organisations such as the Then India Sanmarga Ikya Sangam and the Fiji Muslim League followed in the 1920s. The colonial government's concern for the social and educational welfare of the Indian community was conspicuous by its absence. In this stance, it received the solid backing of the local Europeans. The manager of the Vancouver Sugar Company wrote to the Colonial Secretary in 1914, 'We most emphatically do not require an Indian community of highly educated labourers, with the attendant trouble 
which the 'baboo' class has brought to the Indian Government, teaching and preaching sedition and looking for immediate treatment on a parity with educated Europeans accustomed to self government for many centuries.'

Along with, and perhaps because of, poor educational facilities, the social and political development of the Indian community was hampered by the absence of an English-literate political leadership which could articulate its needs and grievances to the government and to the outside world. This is not to say that there were no important leaders in the Indian community at the turn of the century, for there clearly were. Individuals such as Pandit Totaram Sanadhya, Babu Mangal Singh, Maulvi Mirza Khan are some important names that spring to mind, but their energies were spent in local community affairs, and their wider influence was limited because of lack of English and poor knowledge of the workings of the colonial bureaucracy.

Until 1916, Indians did not have a representative of their own in the Legislative Council. They were represented there by the Agent General of Immigration, a colonial official responsible for the administration and management of the Indian community. In that year, the government nominated Pandit Badri Maharaj as the Indian member of the Council. Maharaj, a wealthy but English-illiterate Raki Raki sugar planter, was well known in the local community for his efforts to promote the education and social welfare for his people. But his choice was widely criticised by the Indian community, which petitioned the government in the thousands to appoint Manilal Maganlal Doctor, the Middle Temple-educated lawyer who had arrived in Fiji from Mauritius in 1912. ${ }^{14}$ Manilal had been sent to Fiji by Mahatma Gandhi at the request of Indian leaders in Fiji.

Soon after arriving in Fiji, this proud, able and effective barrister established himself in Rewa, and began representing the grievances of the Indian community to the government and other bodies. He founded the British Indian Association and started an English language newspaper, The Indian Settler, to educate his people and to represent their concerns and aspirations to the wider world. Manilal was the man of the moment in the Indian community, but the government thought otherwise, calling him 'the worst enemy of Indian progress in Fiji.' Hence it refused to nominate him to the Council, technically on the grounds that as a native of the princely state of Baroda, Manilal was not a British subject and thus ineligible for selection. In truth, however, the government did not want Manilal in its official circle because his compliance could not be relied on. Whatever the official view, Manilal was the most important and widely recognised leader of the Indian community in Fiji until 1920, when the

14 See Lal, 1992, 46-48 
government forced his departure from the colony for his alleged role in a strike that year by serving an order prohibiting his residence in all major Indian areas of the colony, effectively depriving him of his livelihood.

Indenture was abolished on 1 January 1920, ushering in a new era in the life of the Fiji Indian community. Its population increased steadily. More important perhaps was the increase in the proportion of Fiji-born, from 44 per cent in 1921 to 72 per cent in 1936. This change was pregnant with profound social and psychological implications for the community as we shall see in the next chapter. The Indo-Fijian community, formed by new influences and circumstances, was more conscious of its rights, more demanding of the privileges it had been denied during the 40 years it had been in Fiji.

There was a two-month strike in Suva, the first major strike in the history of modern Fiji, when Indo-Fijian workers walked off the job demanding better working conditions and pay increases to offset the increase in cost of living in the colony caused by the disruptions in shipping following the First World War. ${ }^{15}$ The prices of items basic to the Indo-Fijian diet (rice, sharps, dhal, ghee, mustard oil, spices and vegetables) had increased substantially. The government refused to accede to the strikers' demands, used force to crush the strike and arrested the strike leaders.

The following year saw another strike, this time in western Viti Levu involving Indo-Fijian cane growers and the Colonial Sugar Refining Company. The Company's tenants and workers demanded better wages (12 shillings a day), specified work hours, adequate housing, medical and pension benefits, educational facilities for their children and small plots of land to keep milk cows. The strikers were also angered by the Company's decision to alter its procedure for buying cane, no longer valuing it according to the sweetness of the cane but at a flat rate for farms grouped in 30 acre blocks.

Once again, the government used force to quell the strike with the assistance of 250 specially commissioned Fijian constables from Bau. Unfortunately, what began as an industrial strike came to acquire a racial tinge, pitching Fijians against Indo-Fijians, thus further increasing the gulf between the two communities which were already separated from each other through differences of culture, religion, language and history. The so-called ringleaders of the strike, including a recently arrived Hindu priest, Sadhu Basisth Muni, falsely rumoured to be an agent of Mahatma Gandhi, were deported. The Sadhu, even some of the government's own informers believed, was a gentle soul of progressive vision who had exercised a moderating influence in the Indian community, and

15 See Gillion, Canberra, 1977, Chapters 1 and 2; and Lal, 1992, 80-83. 
concentrated his energy on educational and religious welfare of his people. For the next two decades, the relation between the Company and the Kisan (farmers) would continue to simmer, erupting in a strike in 1943.

With the abolition of indenture, the question of the political and social rights of the Indo-Fijian community began to acquire an importance it had not previously had. In 1922, in response to Fiji's request to re-open Indian immigration, the Government of India sent a deputation to the colony to report on the social and political conditions of the Indians already resident there. The deputation, led by Venkatpati Raju, wrote a wide ranging and severely critical report and made a number of recommendations. The Indo-Fijian community should be enfranchised. It recommended the principle of communal representation though only as a temporary measure, with each community having an equal number of seats in the Legislative Council. ${ }^{16}$ The principle of equality was important. The Government of India itself advocated a common roll, and objected strongly to any other system 'intended to assign an inferior status to Indians as compared with their fellow British subjects, and to limit the growth of their political influence in the Colony.' The deputation did not recommend any special franchise qualification for the Indo-Fijian community, but did ask for a slight relaxation of the property qualification for Indo-Fijian candidates.

The colonial government was reluctant to extend the franchise to the IndoFijian community. It would of course never entertain the thought of giving them political parity with the Europeans, citing the government's responsibility to the Fijian people under the Deed of Cession, including the recognition of the interests and rights of the Fijian chiefs. The Government of India agreed that 'these interests must be maintained, and [we] have no desire to question this.' But, it added, 'the elective representation on the Legislative Council at present enjoyed by the European community is presumably regarded as not inconsistent with the terms of the Deed of Cession, and it can hardly be argued that the grant of a similar status to their Indian fellow-subjects would infringe those terms.' The Colonial Office agreed with the Fijian colonial government, and in the end agreed to give the Indo-Fijian community three seats (Europeans had six) on communal franchise.

The Government of India also advised the appointment, by the GovernorGeneral in Council, of an Agent in Fiji under the terms of the Emigration Act (VII of 1922). The Agent would not only look after the interests of the IndoFijian community whose forebears had come under indenture, but would also keep India informed with accurate information about their interests and welfare. Fiji could not divest itself 'of responsibility for the welfare of Indians in Crown Colonies, particularly as long as they have not received adequate representation 
on the Colonial Legislative Council on a footing of equality with all other classes of His Majesty's subjects.' The Fiji government objected and the Colonial Office agreed with it. Electoral representation would enable the Indo-Fijian leaders to articulate the concerns of their community in the legislature. It was far better for the Fiji Indians to look to their own representatives rather than to the representative of another government to defend their interests. However, as a compromise measure, the Colonial Office agreed to the appointment to the Fiji civil service of an 'officer possessed of special Indian experience and language qualification, who will be competent to act as a special advisor to the Governor on matters affecting the Indians in Fiji.' J.R. Pearson, a retired member of the elite Indian Civil Service, was appointed the first Secretary of Indian Affairs in 1927. The office was abolished in the late 1930s, but by then the Indo-Fijian community had its own leaders like A.D. Patel and Vishnu Deo who were able to represent the concerns and interests of their people to the government.

The Indo-Fijian community had travelled a long distance from uncertain, impoverished beginnings in the 1880s to the 1920s. Although 24,000 of the Indian indentured immigrants and their descendants eventually returned to India after completing their terms of service in Fiji, the majority had decided, with government encouragement, to make Fiji their permanent home. For them and their children, new problems lay ahead as they joined the struggle for equal social and political equality in their new island home. The days of unquestioning acceptance of their designated place at the bottom of the colonial hierarchy were numbered. 


\section{Chapter 2: Child of Gujarat}

Who cares for your Bhakti or Mukti? Who cares what the scriptures say? I will gladly go to hell a thousand times, if I can rouse my countrymen, immersed in Tamasa, and make them stand on their own feet and be men, inspired with the spirit of Karma Yoga.

Swami Vivekananda

Ambalal Dahyabhai Patel was born on 13 March 1905 in a Patidar family in the Charotar tract of the Kheda district of Gujarat. He was born in his mother's village of Mahij in the Petlad taluqa (subdivision), in keeping with the traditional Indian practice of women giving birth to their first child at their parents' home. But young Ambalal grew up in his father's neighbouring village of Pihij. That the child defines the man is, of course, a cliche, but like all clichés, it contains a grain of truth. Patel's Gujarati background, the social, cultural and political traditions of the Kheda district, and the early exposure to the nascent stirring of Indian nationalism and the manner of its expression had profound influence on his character and outlook. Kheda district is today well known throughout India for the prominent role it played in launching the Indian nationalist movement. It was there that Mahatma Gandhi started his first satyagraha campaign upon returning from South Africa in 1915. The district contributed more than its share of leaders to Indian politics and public life, such as Vallabhbhai Jhaverbhai Patel, the so-called iron man of Indian politics, and independent India's first Home Minister and Deputy Prime Minister. Its people were spiritually eclectic, proud of their cultural heritage, independent-minded and fiercely anti-colonial. Ambalal Dahyabhai Patel, who came from the most politically conscious and socially prominent strata of the Kheda district, was thus a Gujarati's Gujarati. What he encountered in Fiji simply reinforced his determination to fight colonialism and the culture of petty discrimination and social inequality it spawned. The stubbornness of which Q.V.L. Weston spoke had deep roots in Patel's cultural heritage.

The state of Gujarat lies in western India, ${ }^{1}$ bound on the west by the great Arabian Sea and in the east by the hilly tracts of the Western Ghats which separate the state from Madhaya Pradesh in the northeast and Maharashtra in the southeast. Between the hilly tracts in the east and the sea on the west lie the flat alluvial plains of Gujarat, watered by the Tapi, Narmada, Mahi and Sabarmati. Although Gujarat as a whole is generally regarded as a prosperous state in modern India, the productive capacity of different regions within it vary considerably. The northern part of the state, which once formed its political

1 This section on the geography of Gujarat draws heavily upon the Government of India district gazetteers. 
centre, and was ruled by the Rajputs from the 10th to the 14th century, consists of large tracts of sandy soiled plains. Its political significance declined when the Sultans moved the state capital to Ahemadabad, closer to the great ports of Cambay and Broach. In the south lies the Saurashtra region, known in British times as Kathiawad. The soil here, as in much of the northwest region of Kutch, is poor. The eastern, hilly regions of the district are inhabited by tribal groups, who still live on the fringes of mainstream Gujarat society. It is the central region of Gujarat that constitutes agriculturally the most productive part of the state.

Kheda district, with an area of 7,194 square kilometres (3.7 per cent of the state's total land area) lies in this fertile central region of Gujarat. Within the state, this region is known as the Charotar, the name generally thought to derive from the Sanskrit word Charu (beautiful), but there are other interpretations as well. To most Gujaratis, the cultural and political boundaries of the Kheda district and the Charotar region are one and the same thing. The prosperity of the Charotar region impressed early English visitors. Alexander Kinloch Forbes wrote in 1878:

The fields are, in the richer part of the province, enclosed with strong and high permanent hedges, which, with the noble trees that everywhere abound, render the country so close, that the boundaries of a field circumscribe the view, and unless the hum of voices, the whirr of the spinning wheel, or the barking of dogs, gives him notice of its vicinity, the traveller may enter a village almost unawares. Hedges and trees here swarm with the birds of many varieties, from the peacock to the sparrow; game of all kinds is in great abundance, and monkeys rove about in troops, or rather in armies. ${ }^{2}$

Not surprisingly, the rulers appreciated the fertility of the area, and during Moghul rule, the Sultans of Gujarat reserved the tract for themselves. Under the British, according to David Hardiman, the Charotar 'was one of the most highly assessed areas in India, with a revenue fixed at five times the amount paid on the best black-soiled lands of the Deccan. ${ }^{3}$ So it is not surprising that the Charotari Gujaratis had a well developed and not entirely unjustified regard for themselves and their industry, and were respected, even feared, by groups in neighbouring regions.

Nonetheless, the Charotaris were not a homogenous community. They were differentiated by caste status and place of residence within the region. In 1911 the population of the Kheda district was 716,432: Baraiya and Patanvadiya (peasant cultivators) 266,665 (37 per cent of the cultivators); Patidar (peasant cultivators) 107,805 (15 per cent); Muslim peasant cultivators $(63,280)$;

2 David Hardiman, 1981, 260.

3 Hardiman, 261. 
Brahman (priests) 30,587; Rajput (warriors and rulers) 28,382; Christians 23,592; Dhed (weavers) 18,085; Vaniya 18,929; and lower caste workers such as tanners, blacksmiths, carpenters and sweepers.

Though the Patidar comprised only 15 per cent of the population, they were the most powerful group in the district. The Patidars came from the peasant community of Maharashtra known as Kanbi, a generic name for peasants in this part of India, just as Kurmi was the generic name for peasants in many parts of North India. ${ }^{4}$ Sometime during the Mughal period, the Kanbi of the Charotar tract organised themselves into a community of village rulers and named themselves Patidar. The name is derived from pati (strips of land) and dar (holder). Holders of strips of land, the Patidar assumed the responsibility for collecting revenue for the Moghul rulers. They cultivated the best land while leasing out the less desirable areas to other groups on whom they frequently levied extra taxes, grew the most lucrative cash crops, dominated the trading networks, and controlled local politics through force or patronage. In short, the Patidar were a community to reckon with; it was a brave person indeed who crossed their path. As David Hardiman says:

The Patidar controlled the economy of the village. In normal times, they could ensure that they were always richer than those lower in the village hierarchy. On paper, the Patidars were liable to pay far higher sums of revenue than the subordinate peasantry, for they farmed the richest lands. In practice, they invented a whole range of extra taxes which they imposed on the lower castes. As a result, the lower castes were normally impoverished while the Patidars were comfortably off. ${ }^{5}$

The Patidars maintained their privileged position during the British rule of India.

Socially, the Patidar did not constitute a caste in the strict sense. In fact, the word connotes a 'state of affairs to be achieved,' through competitiveness, appropriately arranged marriages and other such social rituals. ${ }^{6}$ The Kanbi, from whom the Patidar came, were divided into two main groups, the Leva and the Kadavr, their names apparently deriving from Rama's two sons, Lav and Kush. The Patidar belong to the Lav group, and regard themselves as kshattriya, the warrior community. Over time, they appropriated many Brahminic (twice-born) rituals and ideals, such as vegetarianism in diet and worship, the prohibition of widow remarriage, and the love of learning, especially the ancient Sanskrit texts. The one Brahminic practice they discarded as unnecessary, in view of

4 For an interesting historical study on this, see Ravinder Kumar, 1968.

5 Hardiman, 38.

6 David Pocock, 1972, 1. 
their political and economic power, was the wearing of the sacred thread as a formal mark of high status. The Patidar did not need the sacred thread to impose at will their authority on others.

Outsiders were impressed with the Patidar and their spirit of independence. Bishop Herber wrote in 1825:

The Potails [Patels] of Guzerat are very inferior in dress, manners, and general appearance, to the Zamindars of Hindostan. Their manner, however, though less polished, is more independent; and here, as in Central India, instead of standing with joined hands in the presence of a superior, they immediately sit down, even if they do not advance to embrace him. ${ }^{7}$

Forbes, writing around the same time, noted:

The Koonbee, though frequently all submission and prostration when he makes his appearance in a revenue office, is sturdy and bold enough among his own people. He is fond of asserting his independence, and the helplessness of others without his aid, on which subject he has several proverbs, as, 'Wherever it thunders, there the Koonbee is a landholder,' or 'Tens of millions follow the Koonbee, but the Koonbee follows no man. ${ }^{8}$

The Patidar community in the Charotar, however, had important distinctions of rank and prestige based not necessarily on material wealth but on social status which, in turn, derived from the length of residence in the area. Legend has it that around 1697 or 1698, the Patidar leader Vir Vasandas decreed the three top Patidar villages in the Charotar to be Sojitra, Vaso and Nadiad, followed closely by the villages of Karamsad, Dharmaj, Bhadran (the chhagam (six) villages) and Virsad, Nar, Tarapur, Uttarasanda, Od and Pihij, Ambalal's village. This ranking was naturally contested, but at the beginning of this century, these villages were generally regarded as the most prestigious ones not only in the Charotar tract but in all of Kheda district and, by extension, the whole of Gujarat. In a hierarchical and highly competitive society, rank was important. It certainly did not hinder A.D. Patel's standing in the Gujarati community in Fiji. S.B. Patel, another prominent Gujarati leader in Fiji, was from Sojitra, and the businessman and sometime A.D. opponent, Appabhai Patel, was from Dharmaj.

In the 20th century, the Kheda district distinguished itself by the role it played in the Indian nationalist struggle in several ways. As mentioned before, it was the district where Mahatma Gandhi launched his first satyagraha campaign on

7 Hardiman, 36.

8 Ibid. 
behalf of the suffering peasants in 1917, two years after returning from Africa where he had gone in 1893 to work on behalf of the Natal Indians. Many of Gandhi's early campaigns focused on the Charotar region in such places as Nadiad, Borsad and Anand. As a result of this and because of their dominant position in rural society, the Patidar played a prominent role in the nationalist struggle at the local, state and the national level. Among many illustrious nationalists in Gujarat who emerged on the national scene were Vallabhbhai Jhaverbhai Patel (1890-1961) and his elder brother, Vithalbhai Jhaverbhai Patel (1873-1933). A.D. Patel was known to Vallabhbhai, who once asked A.D. to return to India to participate in the nationalist struggle. By then, however, A.D. was deeply involved in Fiji politics, and told the Indian leader that he had decided to devote the rest of his life to his adopted homeland.

A.D. Patel, then, came from a community that was politically powerful, socially prestigious, fiercely independent, land-based and in the forefront of Indian nationalist politics. His community and region had produced leaders who were attracting attention beyond the borders of their district. As a precocious secondary school and university student, Ambalal witnessed at first hand the nascent stirring of an India-wide, Gandhi-led nationalist agitation. Throughout his life, he maintained a deep interest in Indian, especially Gandhian, politics and philosophy. On two occasions, in 1940 and 1946, he visited India to represent Fiji Indian grievances to leaders of the Indian National Congress, including Jawaharlal Nehru. The constitution of the National Federation Party, specifically the structure of the Working Committees, is borrowed directly from the Congress Party's constitution.

Patel's well-known connection with the Indian nationalist movement, and his effort to use the leverage of India to prompt the Fiji government into action, was widely criticised. Both the government and his opponents accused him of unnecessarily introducing extraneous concerns into Fiji. Patel and others like him, the government officials said, talked of preserving the izzat, honour, of the Indian community, but showed no compunction in trampling on the izzat of the colony in the eyes of the world. Patel pointed to the government's indifference, at times even active hostility, to the interests and needs of the Indo-Fijians. It was pressure from the Government of India and an enraged Indian public opinion that ended indenture in Fiji, Patel argued, reminding the government of its effort to continue the system long after its abuses had become public. The Fijians, he said, could (and did) appeal to the Deed of Cession to protect their interests, the Europeans had a sympathetic ally in the government, but the Indo-Fijians were left at the mercy of others. Their only hope of effecting change in the colony's policies was through external pressure. After Fiji gained independence, India gradually ceased to be a source of advice and pressure, but its influence in the 1920s and the 1930s was considerable. 
Another aspect of Patel's social background throws light on a part of his public life in Fiji. For more than two decades, Patel was deeply involved in matters relating to the sugar industry in Fiji. In 1943 and again in 1960, he was the principal leader of the cane growers' strike against the CSR. Many Indo-Fijian cane farmers were perplexed that such an educated and wealthy Gujarati as A.D. Patel should immerse himself in matters and disputes involving poor farmers, then represent them, invariably free of charge, before the various commissions of enquiry. The other Gujaratis they knew were all traders and businessmen, culturally exclusive and self-contained. The difference between the world of the girmitiya and the Gujarati was the difference between chalk and cheese.

Naturally enough, people speculated about Patel's real motives. His critics charged, and some of them still do, that Patel was nothing more than a wolf in sheep's clothing, an agent of the Gujarati community preying on the greedy and the gullible farmers. The main reason for his involvement in sugar matters, they charge, was to divide the farmers so that the Gujarati merchants' economic stranglehold over them would remain unchallenged. Others saw his involvement as a cold-hearted attempt to use the farmers to launch his political career. The Gujarati community was small and could not provide him the numbers to get elected to the Legislative Council. For that he needed the support of the other Indo-Fijians. Muslims had their own leader in Said Hasan, the North Indians had Vishnu Deo. The only people, perhaps the most socially and culturally disadvantaged and discriminated group in the Indian community, who did not have a leader of national stature of their own, were the South Indians. Assessing their unfortunate situation and seizing the opportunity to promote himself, Patel became their advocate, their legal advisor and general manager of their schools. Thus, his critics argue, it was not the thought of service but a coldhearted calculation to advance himself that led Patel to champion the cause of the South Indians and poor, leaderless farmers generally.

Political ambition would naturally have been a factor: Patel was no saint. As an aspiring political leader, he must have mapped out the cultural and social contours of the Indian landscape and assessed the best path to take him forward. But perhaps there are other reasons as well for Patel's involvement in the concerns of the Indian farmers. He had been a part of the landed gentry of Gujarat, many of whose members were variously engaged in agriculture, either cultivating or overseeing the cultivation of such crops as spiked millet (bajari), pigeon pea (tuver), sesame, castor, chillies and culinary spices, and such cash crops as cotton and tobacco which grew well in the fertile soil of the Charotar. It also explains why he became a big landlord himself, owning over 300 acres of freehold land in Savusavu, Sigatoka, which he leased to tenants. He also owned some large cane farms jointly with other Gujarati merchants in Nadi. His demanding relationship with his tenants sometimes became an election issue. 
'How can he accuse anyone of being hard on the farmers when he himself was so hard on his own tenants?' his critics would ask. They said that Patel was extremely money-minded, lacked compassion and demanded that, no matter what the circumstances, his tenants should pay their due on time. If this was true, and there is enough oral evidence to suggest that it might have been so (even though an enquiry by magistrate Arthur Jeddre-Fisher found nothing untoward in Patel's dealings with his tenants), then it reflected aspects of tenant-landlord relations in India. Patel's involvement in farmers' issues was not simply a cold, calculating move to promote his political interests; it was actually an extension of his own social background as a privileged member of the Gujarati farming community.

That privileged status reflected itself in other ways as well. Patel was a man of elegance, style and taste. At official dinner parties, he wore a well-cut dinner jacket and a bow tie. In London, he wore a hat and fashionable overcoat. When Patel went to the constitutional conference in London in 1965, Governor Jakeway invited him to join the official party in the Royal Box along with two former governors, Sir Ronald Garvey and Sir Kenneth Maddocks and the Attorney General Justin Lewis, to take salute of the Band of the Fiji Military Forces at the Royal Tournament. All the other members of the Fiji delegation, including Ratu Mara and Ratu George Cakobau, were seated in the Royal Enclosure. Patel mixed well with members of high society, but when he talked with farmers, he sat on an ordinary chair or on the mat, eating with his fingers as Indians normally do. His personal library was well stocked with books on a wide range of topics, from Indian and Western philosophy to biographies, literature (Thomas Hardy being his favourite author) and how-to-do manuals on horticulture. There was music in the house, Jyotika Roy and Pankaj Mullick being his favourites. Patel himself played the harmonium. Leela was a trained artist with a fine aesthetic sense. In his relations with the outside world, Patel was conscious of his role and status as the leader of the Fiji Indian community. Symbolism was important. So in the 1950s, Patel had a large black Humber motor car, driven by a Fijian chauffeur (who also doubled up as his bodyguard). Only the Governor and the general manager of the Colonial Sugar Refining Company had Humbers. In the 1960s, as tastes changed, Patel bought a Mercedes Benz, the only one then in the colony. A keen horticulturalist, Patel ordered rose plants from New Zealand for his garden at the Waqadra Estate. When Jakeway left Fiji, Patel gave him an orchid plant as a gift. This interest in books, music, flowers, gardening and sartorial elegance remained with Patel throughout his life.

Let us turn now to Patel's family background. Ambalal was born to his father's second wife, Haribai. The first wife had been unable to bear children, and the absence of children was, and is still, considered to be a tragic misfortune for Hindu couples, the curse of the gods for some misdeeds committed in previous 
life. A vital purpose of marriage is procreation, the continuation of the family lineage. For this purpose, the birth of sons was essential; girls could not perpetuate the family line, for upon marriage, they became members of their husband's family. Sons were also essential because only they could perform the appropriate final funeral rites for their father, to ensure the safe passage of his soul to another life. Bearing all this in mind, Dahyabhai's first wife insisted that he marry again. He did, and she continued to live as an integral member of the household.

Ambalal's birth brought great joy to his father, who was then 35 years old, long past the age (in traditional Indian society at least) when men became fathers for the first time. Other children followed: Surajben, Manubhai, Raojibhai and Ishwarbhai. However, as the eldest, Ambalal remained special, in the way most first-born usually are, self-confident, assured of his place in the family hierarchy, somewhat spoilt and used to having his own way. Dahyabhai, the proud middleaged father, was gentle with his children, and according to Raojibhai, always used reason and persuasion with them. He was financially not a particularly well-to-do member of the Patidar gentry, but unlike many in his community, he did not much care for material wealth or social prestige.

Dahyabhai was an intellectual, a respected scholar of Sanskrit and Mathematics. This is a formidable combination of expertise, requiring (and encouraging) logical thinking and analysis and immense powers of concentration and memorisation. Education was his passion. Above all else, he wanted all his children, especially his sons, to be educated. For this purpose, he even mortgaged his house and property so that his children could receive the best education that was to be had in the district. When people asked Dahyabhai about his wealth and investment for his old age, he used to reply: 'My four sons are my investment, my property.' Two of his sons, Ambalal and Raojibhai, became successful barristers, Manubhai became a teacher and Ishwarbhai graduated a medical doctor. Some of his father's passion for education would pass down to Ambalal who would devote a great deal of his time to promoting it in Fiji.

Haribai was a devoted housewife and mother, kind and gentle, who seemed, like most Indian mothers of her time and even now, to have dedicated her life to the welfare of her children. As she often said, 'They are my life.' She taught them the simple pleasures of life, and through her stories and anecdotes about heroic episodes in Gujarat's history, imbued in the children a deep sense of pride in their cultural heritage and a distinct sense of social responsibility. She must have been a very good teacher, for throughout his political life, Patel made constant allusions to stories about Indian gods, ghosts and goblins to illustrate or dramatise his points to Indo-Fijian audiences. Even the hallowed chambers of the Legislative Council in 1969 heard one such story, to underline the futility of the way in which the Sugar Board operated. A devil threatened to devour a 
man. When the man pleaded for mercy, the devil said he would let him go only if the man gave him something to do. If he ever became idle, he would return and devour him. The man assigned all sorts of tasks to the devil, but he kept returning for more. Just when the man was about to run out of ideas for new tasks, he had an inspired thought. He told the devil: 'You keep on climbing up and down the stairs.' That, Patel said, was how the Sugar Board treated the farmers, and people understood what Patel meant.

The Dahyabhais were an orthodox Hindu family in cultural and religious matters. Daily prayers, observance of rituals, and performance of ceremonies were regular and important features of family life. Like most people in the district, and indeed like many in the state of Gujarat, they were followers of the Vaishanav tradition of Hinduism, the devotees of Lord Vishnu. Vaishanavism first appeared as a religious reform movement, like Buddhism and Jainism, but based on theistic principles. In its background stood the Bhagavada Gita, with its emphasis on karma yoga, service without the thought of reward. It was this text which influenced Patel's philosophy and outlook more than any other. It fortified his resolve to confront evil without fear and deepened his belief in the importance of action. The essence of Vaishanavism was a spirit of sympathy for the lower castes and classes of Hindu society. Spirituality required, indeed demanded, social responsibility. In this creed, there was no distinction of caste, people could dine together provided they were the devotees of Vishnu and had been admitted to the fold. ${ }^{9}$ Perhaps this helps explain in part at least Patel's involvement in the struggle of the cane farmers of Fiji.

Haribai instructed her children in religious matters and told them stories from the Mahabharata and the Ramayana, the two great epics of Hinduism. The example of the parents also inspired deep pride in the achievements of Indian culture and civilisation, and in their own family tradition. The children could trace their family genealogy up to eight generations, to the founding ancestor of the clan, Keshuda, who was also known as Vhala Bapa. The children were taught Sanskrit from an early age, and encouraged to read the literature in their own mother tongue of Gujarati. Over the years, Patel developed a deep reading knowledge of Sanskrit. In the 1950s, when he was out of national politics, he began translating the Bhagavada Gita from Sanskrit into Gujarati. His speeches to Indian audiences were often sprinkled with quotations from the Upanishadas. Political addresses frequently became discourses on philosophy and ethics.

Young Ambalal received his primary and secondary education in Nadiad, which was adjacent to his own taluqa of Petlad. The town was a hotbed of nationalist politics. Mahatma Gandhi addressed a meeting there on 21 March 1918 during his Kheda satyagraha campaign urging rich farmers to withhold

9 See Bhandarkar, 1965 
their land revenue to the government. The campaign against the Rowlatt Act, which severely restricted people's freedom as the British attempted to deal with an upsurge in revolutionary political crime in the country, was directed from Nadiad. Gandhi, who had made the town the headquarters of the Rowlatt Campaign, urged people to boycott government schools and colleges and courts, addressed a meeting of some 12,000 on 30 September 1920. Many other such campaigns would follow in later years. It was impossible for anyone, certainly not intelligent, socially conscious students, to be unaware of the new tides in Indian nationalist politics lapping at the gates of their school compounds.

Ambalal attended a small school in his village where he was taught in Gujarati. As he progressed through the grades, however, English was added to the curriculum. It was very early in his school life that Ambalal developed the habit of reading prolifically, frequently asking his father to explain complex concepts he found difficult to understand. Patel continued the habit of reading throughout his life. Jai Ram Reddy who once worked in Patel's office as a young lawyer, recalled him as a 'voracious reader' of everything, magazines, novels, poetry, history, philosophy. Not surprisingly, Patel excelled in secondary school, graduating near the top of his class. Pleased with Ambalal's success, Dahyabhai used some of his pension money to send him for further education at the prestigious Gujarat College in Ahemdabad, the capital of Gujarat. There Ambalal studied economics, politics and history, including English history. Once again, he performed brilliantly, graduating a Bachelor of Arts with honours in 1925, at the age of 20. Some acquaintances recall him as a shy lad, but also a resourceful debater fluent in English and Gujarati.

When Ambalal entered college, it was generally expected that he would train to become a mofussil pleader (a local lawyer) in the district. For young intelligent men of India, law was the preferred profession. It was financially lucrative and socially prestigious. It enlarged one's network in the community. Moreover, the legal profession could and often did pave entry into local and even national politics. The leadership of the Indian nationalist movement was dominated by local pleaders who had risen through the ranks to national prominence. Among the most notable of them was Motilal Nehru, the father of Jawaharlal. In the Kheda district itself, the two most prominent examples were the brothers Vallabhbhai and Vithalbhai.

But there were other plans in store for Ambalal. With the academic success and the tremendous promise he had already shown in college, his family and the village elders agreed that Ambalal was destined for something more than just a district pleader. It was decided that Ambalal should proceed to London and, after an appropriate period of preparation, sit for the Indian Civil Service examination. Nothing in Indian public life, or in the British Empire for that matter, was more prestigious than being an ICS officer. The ICS was 
the preserve of the best and the brightest of Indian and English aristocracy, 'a class of guardians specially trained and chosen,' 'repositories of the wisdom and courage of the state,' men who were persuaded 'that the god who created them had mixed gold in their composition to distinguish them from the common people'. ${ }^{10}$ These were the men who ran the mighty Indian Empire, the much cherished jewel in the British crown. They were the Viceroy's right hand, as the armed forces were his left hand. Until the middle of the 19th century, no Indian was allowed entry into the ICS. The 1857 Mutiny changed that policy as the government realised the need to co-opt the best and the brightest of India's own to administer the country. Satyendra Nath Tagore was the first Indian to enter the ICS in 1863, followed a few years later by Romesh Chander Dutt, Behari Lai Gupta and Surendranath (Surrender Not) Bannerji, all members of the Bengali intellectual and cultural elite. In the 20th century, many ICS men, such as K.P.S. Menon and H.M. Patel, A.D.'s contemporaries, occupied distinguished posts in civil administration and diplomacy.

A.D. Patel went to London in 1925. He could have sat for the exam in India itself, but chances of success were better for candidates with direct experience of the English intellectual, social and political scene. He enrolled himself at the London School of Economics, which, in the 1920s, was under the influence of the great socialist thinker and economist Harold Laski who was one of the few prominent English intellectuals to favour independence, or at least some measure of self government, for India. Among his Indian proteges was Krishna Menon, the turbulent intellectual who later occupied a series of prominent positions in postindependence India, including being its ambassador to the United Nations and its Home Minister at the time of the first Indo-Chinese war in 1962. London in the 1920s was full of bright young Indian men, future leaders of India, who had gone there to study law or to prepare for the ICS or, in the case of some princes, just to have a grand old time at the social centre of the English-speaking world. Among the many London students who later rose to prominence included M.C. Chagla, the future Chief Justice of India, P.N. Sapru, Judge of the High Court, B.R. Sen, future Director General of the Food and Agriculture Organization, Liaquat Ali Khan, one of the founders of Pakistan, and S.W.R.D. Bandranaike, future prime minister of Ceylon. ${ }^{11}$ Leading Indian luminaries also periodically visited London; Rabindranath Tagore, the Nobel Laureate in Literature, was there in 1921. Indian political leaders visited London often for conferences or fund raising or to keep their overseas supporters informed about developments in India.

Indian politics, especially the future political status of India, was a hotly debated topic in university clubs and in such organisations as the India League (re-named

10 Woodruff, 1954, 75-76.

11 See Menon, 1965. 
the Commonwealth of India League in 1923), founded by Annie Besant and in the 1920s headed by Krishna Menon. The League's official goal was to work for a dominion status for India as an equal partner in the British Commonwealth, though later it included freedom and self-determination for the sub-continent among its goals. ${ }^{12}$ Pamphlets were published and resolutions passed denouncing British imperialism. So also, though less heatedly debated, was the question of overseas Indians and their precarious situation in such colonies as Kenya and Fiji.

No one pursued the cause of overseas Indians more tenaciously than the AngloJewish lawyer Henry Saloman Leon Polak, who was a leading member of the India League. ${ }^{13} \mathrm{He}$ had been with Gandhi in South Africa in the early years of the 20th century, and in 1909 published a book that exposed the terrible conditions of the Indian settlers in that colony. Later, he moved to London, where his Indians Overseas Association became an important pressure group for overseas Indians' causes. More than any other individual in London, Polak kept a vigilant eye on Fiji and was an effective spokesman for the cause of Fiji Indian rights in the imperial corridors of power. Aware of the need for educated leadership in the colonies, Polak was ever on the lookout for bright idealistic young men who could be persuaded to go to these colonies to work on behalf of Indian communities there.

Fiji attracted a disproportionate amount of public attention in India and among the watchers of overseas Indian affairs. It may have been partly due to the colony's reputation as a callous trustee of the rights of Indians living in the colony. The CSR's reputation as a ruthless employer, a white company keeping its indentured labourers in bondage, did not help Fiji's reputation. Fiji Indians had the highest suicide rate among all overseas Indians at the turn of the 20th century. The widespread view that Indian women on the plantations were sexually exploited indiscriminately by the overseers and other men in positions of authority was portrayed as a blot on the name of India. Several sympathetic observers, such as Reverend J.W. Burton, had written critically of the moral decline among Indian indentured labourers, and their views were widely publicised in India. ${ }^{14}$ Reverend C.F. Andrews, Mahatma Gandhi's confidante and friend, visited Fiji in 1915 and 1917. His exposure of the social evils of indenture, together with the emotionally gripping account of conditions in Fiji by ex-girmitiya Totaram Sanadhya, ${ }^{15}$ especially about the plight of women, helped to convince the Indian

12 See George, 1964.

13 Tinker, 1976, 24.

14 Burton, 1910.

15 Fiji Dvip Men Mere Ikkis Varsh [My Twenty One Years in the Fiji Islands]. 
government and the public to end the system which had by the turn of the century become a badge of dishonour for a country beginning to demand its own rightful place in the international community of nations. ${ }^{16}$

Because of this adverse attention, and the plea for an effective and articulate leadership fluent in English, Polak and others attempted to persuade some of the young Indians studying in London to go to Fiji. Among them was Shivabhai Bhailalbhai Patel, commonly known as S.B. Patel. He arrived in Fiji on 24 December 1927. A Charotari Patidar from the prestigious village of Sojitra in the Kheda district, and a London-trained barrister, S.B. was one of Gandhi's many secretaries. It was at Gandhi's urging that he came to Fiji. S.B. was by temperament a quiet and reflective man, well-read, much more at home in private negotiations and counselling than on the public stage. He played an influential role in Fiji and Fiji Indian politics in the 1930s and the 1940s, though precisely what he did remains undocumented. For much of his life in Fiji, however, he remained behind the scenes, listening, negotiating, mediating. H.M. Lodhia recalls S.B. as a king-maker, trusted by all sides. Certainly the government used S.B. as a valuable channel of communication to the Indian leadership at critical moments.

A.D. Patel was temperamentally different from S.B. A.D. was a born fighter, who loved the cut and thrust of the public debate, unafraid of, and undaunted by, controversy and willing to go against the grain of public opinion if he was convinced that what he was doing was right. Given his temperament, it is not too much to assume that soon after arriving in London, Patel must have found himself in the company of other nationalist-minded Indian students. I have not seen any record of Patel's London experiences, but they were very important ones for him. One result was that he changed his original plan for an ICS career without conferring with his parents, and proceeded instead to the Middle Temple to qualify as a barrister. In 1928, at the age of 23, he graduated Bar-atLaw of the Middle Temple, and in the same year left for Fiji, giving up what would certainly have been a prosperous legal career and a prominent place in Indian public life.

This decision understandably caused much anguish to his parents, for they had other hopes of their eldest son. His father, Dahyabhai, had retired from teaching in 1927, at the age of 62 on a meagre pension of fifty-five rupees a month. That year the district suffered from floods and drought. The family was facing hard times. Dahyabhai tried to persuade Ambalal to return and practice law in India, and to help with the education of his younger siblings. But Ambalal, the eldest, spoilt, and stubborn as ever, refused, not out of disrespect for his parents but

16 Andrews and Pearson, 1916. See also Lal, 1983. 
because he now felt he had another mission in life. In the end, Dahyabhai acceded to his son's request, and used some of his own pension money to help with his fare from London to Fiji.

There was another compelling personal reason why Ambalal wanted to remain outside India for a while at least. In London, he had fallen in love with an English woman, a divorcee, Patricia Catherall Seymour, who had a young son from her previous marriage. For a Charotari Patidar of A.D.'s background to have a de facto relationship with a foreigner, even if she was English, was something rare; to have a serious relationship with a divorcee with a son was simply unthinkable, beyond the bounds of all social convention. Among those who reportedly held this view was Appabhai Patel, a prominent leader of the local Gujarati community. A.D. knew well the social dishonour his personal life would bring to himself and especially to his aging parents and his siblings. Life in distant Fiji might be different, away from the critical eyes of the intensely exclusive, status conscious Patidar community. This is a guess, but not an unreasonable one.

The picture was complicated by the fact that A.D. had been betrothed to a girl from his community before he had left for London. The Patidar take the institution of marriage very seriously. A Brahmin, says David Pocock, becomes a true Brahman when he is born again at the sacrificial fire and invested with the sacred thread. For the Patidars, 'marriage is the sacrament of confirmation.' ${ }^{17}$ The betrothal was arranged by his parents and other village elders; that was the way things were done in traditional India. Marriage was too important an institution to be left to the whims and tastes of the young. Ambalal was not consulted, and he stubbornly refused to have anything to do with the whole affair. He would choose his own partner or he would not marry at all. In the end, the betrothal ceremony had to be terminated because Ambalal had worked himself into quite a state.

Patricia Seymour arrived in Suva with her young son late in 1933, and she and A.D. were formally married on 25 January 1934. The first few years of the marriage were happy ones, as they explored the country together and set up home first in Ba and then in Nadi. But the happiness did not last long: their interracial marriage was strained in a colonial society rigidly compartmentalised into racial groups, with its well-defined sense of social hierarchy. The couple simply did not fit into the pre-existing order of things. A.D.'s increasing involvement in Fiji Indian and colonial politics, and the constant travelling throughout the colony that this and his law practice required, did not help matters, especially when the London-born Patricia was left alone in Nadi's rustic surroundings for

17 David Pocock, 1972, 1 
long periods of time at a stretch, ostracised by local Europeans and unable to communicate with the neighbouring Indians. She was trapped in a world she could not comprehend or come to terms with.

A.D. Patel's well known wandering eye and rumors of his numerous marital infractions did not help matters. Older men today tell stories - strictly for one's private ear, one is told, if the teller is a Patel supporter, and for public dissemination, if one is his critic! - about the time when Patricia, distraught at all the allegations of unfaithfulness, attempted to shoot her husband. A.D. reportedly escaped by jumping from the window of a house where his wife had caught him flagrante delicto. There are reports in the colonial files about Patel's car always stopping at certain places en route from Suva to Nadi, his nocturnal activities becoming, in the words of one of his later aides, 'the full occupation of wagging tongues, prompting men with beautiful wives to feel somewhat insecure when A.D. was in their vicinity.' The couple separated in March 1939 and divorced on 17 May 1943. A.D. and Patricia kept on friendly terms with each other long after they had separated, and exchanged letters, gifts and occasional visits. They even talked of reconciliation, but it never transpired. Eventually Patricia left for New Zealand, though her framed photograph hung in Patel's office for more than a decade after she left Fiji. Patel's foes berated him for his extra-marital affairs, though he was neither the first nor the last IndoFijian public figure to be accused of infidelity.

Soon after arriving in Fiji, Patel set up his legal practice at Renwick Road in Suva, which was then the heart of the Gujarati (Patidari) business community. A few years later, he moved to Ba, which by the 1930s had become the dominant area of Indian settlement. While he retained an office in that sugar town, Patel moved to Nadi in the mid-1930s, and he remained there for the rest of his life, except for a brief period in the mid-1960s, when he was the Member of Social Services and lived in Tamavua, Suva. His Nadi home at Waqadra, a few miles from the town toward Namaka, was set in lush green surroundings full of flowers and tall majestic trees. He named it 'Shantiniketan' (Gardens of Peace) after Rabindranath Tagore's open air university in Calcutta, a place of peace and solitude, a retreat from the entanglements of a hectic public life. Patel wanted to buy the piece of land where he lived, but its European owners, the Watson family, refused to sell it. He loved its ambience so much that he refused to move to his own freehold property nearby. Like the rest of the Indian community, Patel lived on leased land.

What brought A.D. Patel to public attention was his eloquence as a speaker both in Hindi and English, his impressive, fluent knowledge of Indian culture and philosophy and, perhaps most important, his brilliance as a barrister. According to Karam Ramrakha, Patel was not as great a legal scholar as Said Hassan; his forte was advocacy. And as an advocate, he had few equals in his day. Andrew Joseph 
recalls Patel 'handling each case with vigour and zeal, applying his brilliance with ruthless determination.' Every Crown Counsel 'who had to contend with A.D.'s penetrating mind and ability to magnify some minute issue favouring the defence, feared the final outcome no matter how strong the Crown's case.' Patel never bullied witnesses, Joseph goes on to observe, 'but he did not spare them any agony either.' Jai Ram Reddy, himself a noted criminal lawyer, says that Patel had raised cross-examination to a fine art. He has never met a lawyer in Fiji or elsewhere who could tell whether a witness was telling a lie quicker than Patel. While conducting a trial, Patel never lost his concentration. He mastered his case fully, got inside the mind of the witness, mixed gentle persuasion with artful trickery, leading him through a tangle of seemingly simple questions until he fell into the elaborate trap Patel had laid.

The 1930s were a turbulent time for A.D. Patel. Besides the convulsions in his private life, colonial officialdom had to be tackled head-on to resolve the pressing problems facing the Indian community. To do that, he had to learn quickly the political configuration of the land, and chart his course accordingly. Perhaps even more important, he had to learn to navigate his way through the faction-ridden politics of the Indian community. He was soon to discover how difficult this task really was.

Patel was often his own man, but he sought and valued the advice of leaders, some of whom became his lifelong friends. Among them was S.B. Patel. The two were particularly close in the first two decades of their time in Fiji. By the 1960s, however, their relationship, though amicable, became more remote, as A.D. immersed himself completely in sugar cane and constitutional politics. ${ }^{18}$ S.B. thought A.D. a bit too impatient for change, too much in a rush to accomplish things. In the 1950s, S.B. had thought A.D.'s idea of a colony-wide public library system premature, to which A.D. replied that one did not wait for hunger to begin preparing food. A.D. used S.B. as a sounding board and a conduit of information.

Pandit Vishnu Deo was another close colleague and friend in the early years. Born on 17 July 1900, Deo was a man of limited formal education but gifted with a keen intellect. As a debater and public speaker fluent in both English and Hindi, he had few equals in his day. He joined the Immigration Department as a clerk in 1918, and started his own importing and exporting agency in 1927. Patel and Deo worked particularly closely on land and political issues facing the Indo-Fijian community in the 1930s. The two were at the forefront of the common roll debate and in the effort to negate the colonial government's

18 I base my assessment of the relationship between the two men on conversation with people who knew them both, and on a private note that S.B. wrote to A.D. on 25 August 1960. S.B. sent A.D. a copy of Kipling's famous poem 'If' and wrote the following words in the margin: 'have always regretted my not coming any closer to you, perhaps I have not tried enough.' 
attempt to replace election to the Legislative Council with nomination. Deo was the founding president of the Indian Labour Union in 1930 and of the Southern Cane Growers Association, besides managing schools and other voluntary social organisations such as the Gram Sangathan Mahila Mandal, Nav Yuvak Sabha, the Swaym Sevak Dal and the Gram Sudhar Sabha. He was also the leader of the Arya Samaj in which capacity he got embroiled in the heated religious politics of the post-indenture period. In 1932, Vishnu Deo involved himself in the publication of a book, Fiji Men Arya Samaj se Shastrath [Debate with the Arya Samaj in Fiji], which the government declared to be 'wicked, scandalous and obscene. ${ }^{19}$ Vishnu Deo was charged for peddling obscenity. He pleaded guilty, was fined $£ 5$ and bound over for 12 months. This blemish on his record did not damage Deo's public credibility though. It was his service to the community at large which earned him widespread respect, and which people still recall with gratitude even today. ${ }^{20}$

Relations between Deo and Patel foundered in the late 1940s over their competing ambitions to become the first Indian member of the Executive Council. Patel managed to out-manoeuvre Deo, but Deo took his revenge by using his widespread influence and powerful contacts to keep Patel out of the Legislative Council twice, in 1950 when Patel was defeated by the first Fijiborn Indian lawyer Tulsi Ram Sharma, and by Ajodhya Prasad in 1953. Patel did not enter the Legislative Council until 1963. The bitterness that this caused gradually evaporated when Deo retired from the Legislative Council in 1959. He died on 7 May 1968.

Patel's greatest friend and confidante throughout his life in Fiji was Swami Rudrananda, a monk of the Ramakrishna Mission. The two saw each other virtually every day of their lives. Swamiji was a regular dinner guest in the Patel household. When the Patels were away on overseas visits, Rudrananda kept them informed about the children and their antics through letters which make hilarious reading. In one such letter in 1962, he told A.D. and Leela how their tiny daughter, Shyama (Amita), kept everyone amused with her song 'Pyaar kar lo nahin to phansi pe chad jayega!' [Fall in love otherwise you'll face the gallows!] The two held weekly Bhagavad Gita classes at the Mission ashram in Nadi, and took turns holding religious discourse at ashrams throughout Viti Levu. They co-founded the English weekly The Pacific Review and the Hindi weekly Jagriti, both published by the Sarada Sangam Press. They also co-founded Fiji's first private, non-Christian secondary school, The Sri Vivekananda High in Nadi. Both were the principal leaders of the growers in the 1943 strike, which earned them the wrath of the colonial government in the form of a house arrest order restricting their mobility to within a five mile radius of the Nadi town.

19 Fiji Samachar, 5 March 1932.

20 See generally, Billimoria, 1985,15: 103-129; and Kelly, 1992. 
Swami Rudrananda (Muthukrishnan) was born in a well-to-do family in Tamil Nadu in March 1901. Heeding Mahatma Gandhi's call for young people of India to devote their lives to the cause of social reform, Rudrananda joined the Ramakrishna Mission and came to Fiji in 1939 on the advice of Swami Avinasananda, who had visited Fiji in 1938 and obtained government approval for the Mission to work in the colony. Rudrananda was no bookish, templebound monk, he was a social activist. 'You don't talk religion to a hungry man,' he responded to those who asked him not to mix religion with politics. He was concerned to create a fair and just society in Fiji, to improve the living condition of the cane farmers then so firmly under the thumb of the Colonial Sugar Refining Company. Rudrananda, like Patel, was a fearless crusader for the things he believed in. His zeal so annoyed his opponents that they petitioned both the colonial government as well as the Mission headquarters in India itself to have the monk removed from Fiji. The same people had also called for Patel's deportation, in both cases unsuccessfully. Patel and Rudrananda, one a patrician lawyer and the other a rustic monk, were two unlikely peas in the same pod, but together they formed a formidable team, dedicated to the project of social and political reform. They both left behind permanent footprints on the soil of their adopted homeland. 


\title{
Chapter 3: Into the Fray
}

Communal franchise is wrong in principle and harmful in practice. The time has come in Fiji for all races to get out of the thin water-tight compartments and start thinking in terms of residents of Fiji.

\begin{abstract}
A.D. Patel, 1929
The question of equality has been raised and I should like to say publicly that, so far as Fijians are concerned, we think we are very well treated, and for the next two or three generations we look to European leadership and expect the Europeans to lead us until such times as we are able to guide ourselves.
\end{abstract}

Ratu Sukuna, 1933

European dominance in Fiji came under increasing challenge in the 1920s and the 1930s from the local Indian community demanding its appropriate place at the colonial table as well as from the Government of India. It was clear that Fiji could not, and would not be allowed to, continue to tread the path of gradualism of the previous half century of colonial rule. Indian leaders, A.D. Patel among them, were in the vanguard of the effort to give their people political representation and economic opportunity commensurate with their numbers and contribution to the economy. An equally important part of their political project was the social improvement of the Indian community, now gradually emerging from the shadow of indenture.

In 1936, the population of Fiji stood at 198,379, comprising 97,651 Fijians, 85,002 Indians, 4,028 Europeans, 4,574 Part-Europeans, and the rest made up of Pacific Islanders, Chinese and others. Of all the groups in Fiji, the Indian population had registered the largest absolute increase, by 24,368 , from the previous census in 1921. Within the next decade, the Indians would become an outright majority in the population, spawning fears of Indian domination of the political and economic agenda of the colony. This development deeply affected the outlook and attitude of other groups in Fiji and influenced government policy.

Throughout this period, the Indo-Fijian community continued to live in rural areas and depended on the land for its livelihood, which created problems of its own. In 1936, for example, some 12,000 Indo-Fijians were working in sugar cane-related work as planters, cutters and general labourers, while others were cultivating such cash crops as cotton, tobacco and rice. Small but increasing numbers were also becoming residents in the sugar towns of Viti Levu, such as Ba, Lautoka, Nadi, Sigatoka, Navua and Vaileka. The descendants of the girmitiyas 
were joined in the 1930s by small numbers of 'free migrants' from the Punjab and Gujarat. The Punjabis came from the migration-prone districts of Ludhiana and Jullundar and Hoshiarpur in the Doaba, which had long furnished migrants to other parts of the world, especially to the Pacific coast of North America. ${ }^{1}$ The Fiji Punjabis, predominantly Sikhs, found a niche in commercial agriculture and dairy farming, where they prospered. Along with a well deserved reputation for industry and thrift, the Punjabis were also well known - notorious - for their independence and devotion to the cause of Indian nationalism. In the 1920s, several of them were members of the Ghadr movement, an organisation founded in San Francisco in the early years of this century to overthrow British rule in India by force. By 1930, there were some 2,000 Punjabis in Fiji.

Another stream of free migrants to Fiji came from Gujarat. Gujarati migration has particular significance for our story and deserves an extended treatment. ${ }^{2}$ The first Gujarati migrants to Fiji were a couple of Parsi artisans who arrived in 1901, recruited in the Bombay Presidency by Thomas Hughes of the CSR. Little is known about their background. The next Gujaratis to arrive in Fiji were Chunilal Ganji and Virji Narshi (Sonar or goldsmiths). From Porbandar in Kathiawar, they came in 1904. Four years later, Narotam Karsandas and Motiram Narsey, both Khatri (traders), arrived in the colony from the Navsari division of the Baroda state. These two groups dominated the Gujarati population in Fiji in the early years, their numbers increasing through family-sponsored migration. In later years, other artisan castes, such as shoemakers (mochi), tailors (Darji), barbers (Nav), launderers (dhobi) and hawkers augmented Gujarati numbers in Fiji. Most of them came either from Navsari or from Surat in British Gujarat. Thus, between 1916 and 1920, of the 752 Gujaratis who applied for passports to migrate to Fiji, 336 were from Surat and 296 from Navsari. The rest were from Kathiawar. $^{3}$

Patidari migration to Fiji began with the arrival of Appabhai Lalubhai Patel in 1914. He came from the socially prestigious Chaggam village of Dharmaj. Soon afterwards, he was joined by another Patidar, Chimanbhai Patel. Because of his high caste and social status and his considerable business acumen, Appabhai quickly established himself as an influential man of considerable power within the Gujarati community. In 1917, he formed a trading Company called A.J.C Patel and Company in partnership with Chimanbhai Patel and J.P. Maharaj, with branches in Lautoka, Nadi, Ba and Sigatoka. Appabhai was personally responsible for bringing some 21 Patidars into Fiji between 1920 and 1934. The Patidar traders settled in the sugar towns of Fiji in western Viti Levu (Ba, Lautoka,

1 On the history of Sikh migration generally, Kessinger, 1974.

2 Much of this is based on the doctoral thesis of Kamal Kanta Prasad on the Gujaratis. I acknowledge my debt to Dr Prasad with the hope that he will make his fine study more widely available.

3 Prasad, 1978, 130. 
Nadi and Sigatoka). Although the Patidar migrants began their life in Fiji under the guidance of Appabhai, and constituted a close-knit community, many of them subsequently broke away or moved on to start their own businesses in different parts of Fiji.

The high tide of Gujarati migration to Fiji was from the 1920s onwards, its population increasing from 324 in 1921 to 1,200 in 1930 to 2,500 in 1935. At first, the Gujaratis attracted little attention from the rest of the Indian population but this changed as their numbers increased and as they became the dominant and the most visible trading group in the Indian community. Of the 600 Indian business registrations between 1924 and 1945, Gujaratis held 300 trading licenses while North Indian Hindus held 192, Muslims 34, South Indians 19, Punjabis 24 and others nine. ${ }^{4}$ Needless to say, their commercial success made them the target of other Indian groups. Several Fiji Indian leaders wanted free migration from India discontinued altogether. The Gujarati social and cultural exclusivity and aloofness from the broader Indian community compounded the problem caused by economic competition. A new source of friction was thus born in the Indian community: India-born versus Fiji-born, new immigrants versus the descendants of the original migrants, the girmitiya. A.D. Patel did not escape the consequences of this controversy.

This is not to say that all the descendants of the girmitiya were united or culturally homogenous. On the contrary, deep divisions racked the community, mostly along religious lines. There were the predictable Hindu-Muslim divisions, newly institutionalised in the 1920s. The Muslims declared themselves to be a separate community, a racial group, wholly different group from other Indians, and thus deserving separate electoral representation in the Legislative Council. Within the Muslim community, however, there were further divisions between the Shia and the Sunni, the theological dispute centring around the question of who was the rightful heir to the leadership of the Islamic faith after Prophet Mohammed's death: the caliphs or the immediate members of the Prophet's family. Was Mohammed the last Prophet of God or were there others to follow him? Among the Hindus, there were bitter conflicts between the orthodox ritual-observing Sanatanis and the self-confessedly more reform-minded Arya Samajis. The Arya Samajis, however, were the better-educated and more cohesive group, and correspondingly more assertive in the political arena. Their activism, in turn, aroused the suspicion of other groups which feared Arya Samaj dominance. Any aspiring leader had to negotiate his way through this minefield of religious and cultural factionalism in the Indian community with great tact and skill. A.D. Patel soon discovered how fraught that task was. 
With the arrival of A.D. and S.B. Patel, the tenor of Indo-Fijian politics changed in a number of ways. The Patels were not satisfied with the status quo and they would not be silenced or out-maneuvered with promises of piecemeal changes within the existing institutional arrangements; they questioned the fundamental moral and political values which underpinned the colonial order. Overhauling the system and not merely tinkering with it was their ultimate goal. To be effective, they needed political organisation as well as concrete plans for programmatic action. Several quasi-political bodies were formed or reactivated, including the Fiji Indian Congress and the Indian Association of Fiji, and regular Fiji-wide conferences were held to discuss major issues concerning the Indian community. The Patels were able to articulate the grievances of the Indian community much more effectively than their counterparts before them. Here, their command of the English language, their legal knowledge and their familiarity with western ways helped. They showed an independence of spirit and a tenacity of purpose lacking in the past; they could not be ignored. They were also effective in using their connections with organisations and individuals outside the colony in London, India and Kenya, to publicise their causes, much to the frustration and embarrassment of the local authorities, who had hitherto managed to keep the lid on the affairs of the colony.

A.D. Patel was propelled onto the public stage soon after arriving in the colony. In 1930, he was elected president of the Fiji Indian Congress in Lautoka, which merged, through the mediation of S.B. Patel, with another rival body of the same name formed in Suva by Hamilton Beattie, a Scottish medical doctor generally sympathetic to the needs and aspirations of the Indian community. The same year, he was elected president of the Indian Association of Fiji, an umbrella organisation of Indians, which convened meetings to discuss issues affecting the Indian community. He was also elected president of the Indian Chamber of Commerce, patron of the Gujarat Mandal and General Manager of the schools run by the Then India Sanmarga Ikya Sangam, the cultural organisation of the South Indians. In his various capacities, Patel frequently presided at meetings all over Viti Levu as well as Vanua Levu. As president of the Indian Association, he corresponded with leading figures outside the colony. Kodanda Rao visited Fiji in 1936 at the invitation of the Association, and Patel helped facilitate C.F. Andrews' visit to Fiji in the same year.

The first political campaign in which A.D. Patel participated, though not as its leading member, was the Indian demand for a non-racial common roll system of voting. Indians were given franchise and three seats in the Legislative Council in 1925, after pressure from the Government of India. Until then, as already seen, the Council had no Indian representation apart from one nominated member, while the Europeans enjoyed six seats and the Fijians five, the latter's representatives being chosen by the Great Council of Chiefs. The new Legislative 
Council elections took place in 1929. A.D. Patel was approached to stand but was ineligible as he did not yet meet the two year residency requirement for candidates. S.B. Patel preferred to remain behind the scenes. The three candidates chosen by the Indian Association were Vishnu Deo for the Southern Constituency, Parmanand Singh for the Northwest, and Ram Chandar Maharaj for the East. All three were elected.

Once in the Council, the three representatives, but Vishnu Deo in particular, asked a lengthy list of questions that focussed attention on the disadvantaged position of the Indian community in education, commerce and the public sector, and the government's apparent indifference to its needs. ${ }^{5}$ Then on 5 November 1929, Vishnu Deo moved that the 'political rights and status granted to Indian settlers in this Colony along racial lines are not acceptable to them;' and that 'Indians in Fiji should be granted Common Franchise along with other British subjects resident in the Colony.' He stated the reasons, which had been canvassed and carefully choreographed at meetings of Indians throughout the colony. $\mathrm{He}$ reminded the Council of the promises of equality which both the colonial as well as the imperial governments had made to the Indian community. The Salisbury Despatch was mentioned as well as the government's undertaking in 1920 that 'the position of Indian Immigrants in Fiji would be equal to that of all other subjects of His Majesty's resident in Fiji.' The granting of common franchise would not detract from promises in the Deed of Cession made to the Fijian people. 'The interests of the Fijians,' Vishnu Deo said, 'must be paramount, and they must be maintained.' The Indian community had no desire to question the rights and privileges enjoyed by the Fijian people. Nonetheless, 'the elective representation on this Council at present enjoyed [by Europeans] is presumably not regarded in any way inconsistent with the terms of the Deed of Cession and it can hardly be argued the grant of a common franchise would infringe those terms.'

Along and tense debate followed, but in the end the common roll motion was defeated whereupon the three elected Indian representatives walked out of the Legislative Council. When they refused to reconsider their boycott decision and missed three consecutive sittings of the Council, their seats became vacant. To break the impasse, the new governor, Sir Murchison Fletcher, convened a meeting of the leading Indian leaders at the Government House in December, 1929. The Indian delegation included A.D. and S.B. Patel, Vishnu Deo, Dr Deva Sagayam, John F. Grant, Abdul Karim, Ram Chandra Maharaj, and Parmanand Singh. At the conference, Fletcher, who had previously served in Ceylon and was thus familiar with the nature of communal politics on the Indian subcontinent,

5 Fiji Legislative Council Debates, 1929 for a full discussion. 
said that the communal roll was the best system for Fiji, in view of its divided social structure and disparate political interests. He then invited the group to respond. A.D. Patel replied:

Communal franchise is wrong in principle and harmful in practice; the time has come in Fiji for all races to get out of the thin water-tight compartments and start thinking in terms of the residents of Fiji. The last election has clearly shown the mutual antagonisms of different races in this Colony. Acceptance of the present franchise would accentuate those differences instead of alleviating them. Unless and until the present constitution is changed, we cannot see our way to cooperate with the government through this Council. The question of a common franchise is an imperial question which would have to be solved presently by the Imperial Parliament. Meanwhile, we are quite prepared to cooperate with the Government if and when they require our cooperation but not through the acceptance of the present franchise. ${ }^{6}$

S.B. Patel agreed, saying that 'equal political status is the essential condition for co-operation with the Government. Under a communal franchise, we are granted second class citizenship.' Others present at the meeting expressed similar sentiments, though later John F. Grant changed his stance and told Dr McGusty, the Acting Secretary of Indian Affairs, that he had been 'shamed' by the Indian community into acquiescing. Parmanand Singh also backed off. Some prominent leaders such as Rev Deoki, Abdul Aziz Khan, Ratu Ram Samujh, Rahiman, Ilahi Ramjan, David Dudley, Gurdayal, Durga Prasad, X.K. Nasir Dean, Spuran Singh and Nabi Buksh supported the more 'moderate' group. Wrote A.R. Sahu Khan, the district clerk from Ra: 'To the minority Indian (which includes Indian Christians and Muslims who on occasions joined hands) communities, common roll is tantamount to transferring political power from European to Hindu hands, and experience in India bids them to trust the former more than the latter. Hence they feel opposed to a common roll. ${ }^{7}$

But that was a minority view in the Fiji Indian community. The response from overseas supported the common roll campaign. The East African Indian National Congress in Nairobi passed a resolution in December 1929 fully sympathising 'with the Indians in Fiji in their fight for equality of status with Europeans in that colony and supports their movement on the direction of non-participation in the legislature till their goal is reached.' Mahatma Gandhi, who had been cabled about the issue, wrote:

I congratulate the three members on their patriotic spirit in having resigned from the Council by way of protest. I hope that they will on no

6 Fiji Samachar, December 1929.

7 Colonial Secretary Office File 51/102/13. 
account reconsider their decision unless a common franchise is obtained. Having resigned, however, they must not sit idle but continue their agitation for the simple justice to which they are entitled. If the Indian colonist in Fiji is well organised, the citadel of anti-Indian prejudice is bound to breakdown through united effort. ${ }^{8}$

Good advice, but the reality on the ground was different. The most important problem facing the Indian community was lack of unity. Many Indian leaders, either out of self-interest or because of genuine conviction, thought that cooperating with the government would produce better results. Muslim leaders, who wanted separate representation, thought the common roll campaign to be detrimental to the interests of their community. They feared being submerged by the Hindu majority, and they, like the others, were not immune to the current of communal politics on the Indian subcontinent. The Europeans were almost viscerally opposed to the extension of any political privileges to the Indians. As Henry Marks told the visiting Secretary of State L.S. Amery in December 1927, if government policy was to encourage the development of social and political consciousness among the Indians, 'we are starting one hundred years too soon. ${ }^{9}$ 'We have the Indians here,' he said in 1929, 'and we must make the best of it and teach them: 'We' are the Colony and not the Indians.'10

Marks and other like-minded Europeans were supported by Fijian leaders who saw, and were encouraged to see, a common cause with Europeans. In 1933, the Great Council of Chiefs passed a resolution, recording its 'strong and unanimous opinion that Fiji, having been ceded to Her Majesty the Queen of Great Britain and Ireland, Her Heirs and Successors, the immigrant Indian population should neither directly nor indirectly have any part in the control or direction of matters affecting the interests of the Fijian race. ${ }^{\prime 1}$ The resolution actually meant the affairs of the colony of Fiji. The resolution was noted and duly sent to the Colonial Office in London.

Fletcher was determined to stop the common roll campaign, which Patel and Vishnu Deo were continuing throughout Viti Levu, not altogether successfully because when the by-elections for the Indian seats were held in 1932, two of the seats were contested, the Southern seat by K.B. Singh and the Western seat by Munsami Mudaliar. Fletcher also set out to marginalise the mainstream of the Fiji Indian leadership. Like many Europeans at the time, he thought that most Indian people were content with their condition, ignorant of the world and uninterested in politics; that they were being manipulated by unscrupulous leaders for their own gain. He conceived several strategies to effect his plan.

8 Young India, 21 November 1929.

9 Colonial Office Series 83/103.

10 Fiji Times, 6 June 1929.

11 Colonial Office Series 83/210. 
With his previous assignment in Ceylon, he tried to play the religious card by recommending a separate seat for Muslims. The interesting thing, as Patel told Robert Norton in 1966, was that the proposal was initiated by Fletcher himself, and not by the Muslim leaders. ${ }^{12}$ Fletcher floated an idea which later Muslim leaders would embrace as their own. The Colonial Office rejected the proposal on the grounds that it would exacerbate tension between Hindus and Muslims. The Muslims constituted a small percentage of the Indian population, and there were only three seats for the Indian community in the Legislative Council. Moreover, the Government of India supported common and not communal roll. When the Muslim strategy failed, Fletcher proposed the introduction of more Chinese into the colony 'as a useful counter-balance to the Indians.' But Australia and New Zealand did not want 'yellow labour so near [their door]' and the Colonial Office would not sanction the introduction of yet another ethnic group into an already complex situation. ${ }^{13}$

When all these strategies failed, Fletcher settled on changing the electoral system. He proposed the abolition of the elective system altogether and its replacement with nomination. That, he felt, would increase government control over political development, stall the drive for common roll and reduce the influence of the Indian politicians whom Fletcher condemned as the 'uninformed tool of an extraneous organisation which is dangerously seeking opportunity to use the Colony for the purposes of world-wide attack upon the British raj.' ${ }^{14}$ Fletcher then set about orchestrating the passage of the motion in the Legislative Council. On 17 May, 1935, K.B. Singh, the member for the Indian Southern Division, moved:

That in the opinion of this council it would be in the best interests of the Colony and the various races resident therein if the European and Indian Members as well as the Fijian Members were nominated and not elected, an equal number of seats to be reserved for each of the communities. ${ }^{15}$

The motion was passed by five votes to three. The government asked the Colonial Office in a secret despatch on 27 May to accept the motion, and to amend the Letters Patent accordingly. Nomination, it said, would ensure the representation in the Council of all sections of the Indian community, and not only of the more vocal sections of the Arya Samajis; it would also curtail the threat to European dominance; and, an important consideration, the Fijians supported the move.

Europeans supported the proposal, though they regretted reversion to nomination. Publicly they supported the move because it would neutralise the

12 A tape of the conversation is in my possession.

13 Lal, 1992, 63.

14 Lal, 1992, 93-94.

15 Colonial Office Series, 83/210. 
demand for common roll. Privately, they supported it because it would keep the Europeans on top of the steadily increasing Part-European population. Without nomination, the Europeans feared being swamped. As Sir Philip Goldfinch, the General Manager of the CSR said, he was opposed to the introduction of the nomination system 'but the half-caste argument had persuaded him.' ${ }^{16}$ Fijian chiefs naturally supported the government. So, too, did some Indians. Some orthodox Hindus, resentful of Arya Samaj dominance of the Indian political agenda, agreed with the Governor, as also did some Muslims. One of them thought the whole idea of democracy ridiculous. In a petition to the Governor on 4 March 1935, Fiji Muslim League president Diljan and Secretary Hasan Raza said they supported the nomination system in the hope that Muslims might be nominated to the Legislative Council. A petition signed by ten Muslims said:

Members chosen on the elective principle possess a positive vice for that they always dance to the music of the ring leader amongst their constituents, and often aim at gaining cheap applause and thus sustaining their popularity amongst the masses, even if it is at the expense of their own community's welfare. De facto, the elective principle, as compared with the nominative principle, simply transfers the power of selection from the head of the Administration to the garrulous 'soap-box' orator. ${ }^{17}$

In a direct reference to people like A.D. and S.B. Patel, the petition said: 'We have seen enough of men who are mere 'birds of passage' and who have come here simply to reap a fortune. They are undoubtedly shrewd and full of tactics for their personal and selfish ends; but we repose no trust in them where our welfare and the interests of the colony are concerned.' They hoped that when the nomination system was introduced, that the interests of the Muslim community would be kept in mind.

The division of opinion in the Indian community was one reason why K.B. Singh moved the motion. But he had other personal motives as well. Singh was a government man, and assured by the Governor of being nominated to the Legislative Council after the expiry of his first term. Assured of official patronage, Singh urged the Governor in January 1934 to create an intelligence branch for Indians 'without delay' to maintain surveillance of Indian politicians; to require the presence of government officers at all meetings of Indians; to take action against Indian 'ring leaders' who should be required to submit in advance programs of their meetings for government scrutiny. 'I respectfully

16 Colonial Office Series, 83/206

17 Colonial Office Series, 83/210. 
submit that if Your Excellency takes me in your confidence, I hope that I will be able to perform my duties more satisfactorily and make Your Excellency's policy completely successful. ${ }^{18}$

The majority of the Indian community, however, was opposed to the nomination system, and sent petitions to the Governor and to the Secretary of State in London. A.D. Patel and Vishnu Deo, president and secretary respectively of the Indian Association of Fiji, led the anti-nomination campaign. Early in June, the Association telegraphed H.S.L. Polak of the Indians Overseas Association:

Great majority of Europeans and Indians strongly oppose motion adopted by Fiji Legislature advocating immediate change from elective to nominated representation without mandate from community. Two discredited Indian members and three Europeans for and three Europeans against motion. Telegraphed to colonial Office by Acting Governor with request for instruction to extend life of Council expiring next month. Fijians neutral. Indian community beseech you take effective steps immediately to retain franchise. ${ }^{19}$

In a petition to the Governor in March and a memorandum in May, 1935, Patel and Vishnu Deo argued against nomination. ${ }^{20}$ They said that K.B. Singh and Munsami Mudaliar did not represent the interests of the Indian community and therefore had no mandate to support the motion. Their only reason was political survival: they knew that they would not be returned at the next election, and so the 'introduction of a system of nomination is their only hope of ensuring their seats in the Council.' The nominated members, moreover, would be mouthpieces of the government and not genuine representatives of the people. 'Our experience and knowledge of the type of Indians nominated by the Government to fill the positions in different local bodies, and in the Legislative Council of this Colony in the past, gives us strong reasons to believe that the people nominated by the Government will be on the whole people who will be acquiescent to the Legislative and Executive measures irrespective of whether they will be in the interest or against the interest of the community.'

For Patel and Vishnu Deo, 'the right of having a voice in the Legislative and Executive affairs of the State is the most valued and highly cherished right of every citizen irrespective of whatever creed or race he belongs, and we may be well pardoned if we are not prepared to relinquish it in favour of a system of nomination which means a complete denial of that most valuable right.' The 'suggested reversion to the nominated system of representation is not in the

18 Singh wrote to the Governor on 9 January 1934 in Colonial Office Series, 83/206.

19 The petition was sent on 12 June 1935 and is in Colonial Office Series 83/210.

20 The petition was signed by hundreds of people from all the Divisions of Fiji; a copy of it and the memorandum is in my possession. 
best interest of the Colony and the various races resident therein [which] would be a direct negation of British democratic ideals.' It would be a backward step as well, 'like filling new wine in old bottles.' It would be opposed by the Indian community. Why the haste, Patel asked? Why not hold a referendum on the issue to test public opinion? 'Six months or a year is but a moment in the history of any country. There is no urgency to effect any change in haste. 'Haste is waste' may be a common saying but it contains nuggets of wisdom which are not unworthy of being carefully considered.'

In the interview with the Governor at which the memorandum was presented, several issues were raised. The following exchange took place between the Governor and Patel:

Governor: Is it the desire of those who have signed the memorandum that there should be a common electoral roll?

Patel: The common roll principle is adhered to but the suggestion is that the wish of the people be ascertained from their representatives after the next general election.

Governor: Is it desired by the deputation that the common roll principle should be applied at once?

Patel: If a common roll is not attainable at present time the matter would not be pressed.

Governor: On the assumption that the common roll principle at present is unattainable, would you regard the present distribution of seats equitable?

Patel: No.

Governor: How far do you subscribe to my contention that the principle of equality between the three races would be attained by an equal distribution of seats between the three races?

Patel: While the common roll is unattainable, we would regard this as satisfactory.

Governor: In view of the opposition to the elective principle of the Fijians and of Indian minorities, do you regard the elective or the nominative system as the better suited to the conditions of the Colony?

Patel: It is admitted that the Indian community is not homogenous, but we ask that the elective principle should be retained.

Governor: At an election what likelihood is there of a Muslim candidate being returned? 
Patel: A Muslim candidate would have an equal chance with a candidate derived from any other Indian section or community. ${ }^{21}$

Despite this and other representations, Fletcher remained unmoved, and pressed the Colonial Office to adopt nomination. But the Colonial Office balked, not only because it thought that a retrograde step when its ultimate goal was to encourage the emergence of representative government in the colonies, but also because the Government of India was opposed. On 30 September 1935, Ram Chandra, officiating secretary to the Government of India, wrote to the Secretary of State for India in London that the Standing Committee on Emigration of both the Houses of the Central Legislature had 'urged that the proposal to substitute nomination for election is a retrograde step' and should not be adopted. Faced with conflicting pressures, the Colonial Office devised a compromise, combining nomination with election. It proposed to increase the Legislative Council to 31, made up of 15 unofficial members and 16 official members. Each of the three ethnic groups would be allocated five seats. All the Fijian seats would be nominated by the Great Council of Chiefs, but three each of the Indian and European seats would be elected on communal franchise and the remaining two filled through nomination. The Fiji government agreed, and the system, introduced in 1937, remained unchanged till 1963.

Along with political representation, land was an issue which featured prominently at nearly every conference of Fiji Indian leaders throughout the 1930s. It was the major item on the agenda of the all-Fiji Indian conference organised by A.D. Patel in October 1929. That meeting urged the government to 'consider the advisability of granting long term leases to Indians and submits that the renewal and extension of leases should not entail any hardship to tenants.'22 At the same time, petitions were sent to sympathetic organisations in India and London to increase pressure on the colonial government to act expeditiously in the matter. At another major conference Patel organised at the Lilac Theatre in Suva in October 1938, which was presided by Pandit Hriday Nath Kunzru, the eminent Indian statesman, land was the major issue. Resolutions called for a commission of enquiry, comprising representatives of the Fiji Indian community, the Government of India and the colonial government, to investigate the economic condition of the Indians, and to recommend expeditious renewal of leases, opening up of new land, and greater security of tenure. The colonial government was reminded of 'the urgent need for legislation to regulate the relations of landlords and tenants and to allow to tenants the rights and protection enjoyed by them in all civilised countries. The present position is giving rise to widespread and acute discontent and unless dealt with fairly and boldly

21 In Colonial Office Series, 83/210.

22 Fiji Samachar, November 1929. 
will prove seriously detrimental to the future development of the colony.'23 The conference also asked the Government of India to 'take early action to prevent tenants from being forced to work for any individual or association.' Other resolutions called for the training of more Indian medical students, extension of medical facilities to rural areas, the establishment of Indian child welfare centres and training of Indian nurses, ${ }^{24}$ and the provision of running water to districts where this was not available.

It is not necessary here to dwell at length on the cumbersome procedures that governed the leasing of land in Fiji before and up to the 1930s. It is enough to note that it was chaotic and often led to corruption. The potential leassor, in the first instance, had to apply to the Commissioner of Lands in Suva or to the Commissioner in whose district the land was located. The Commissioner then notified the local Buli (local adminstrator), who in turn brought the application before a meeting of the District Council, at which the Fijian landowners expressed their views about the proposed lease. The Buli conveyed the decision of the Council to the Commissioner who then made a recommendation to the government. There, the application and the recommendations were considered by the Commissioner of Lands and the Secretary of Native Affairs. If they approved, the lease was then sold at a public auction to the highest bidder. This procedure was simplified in the mid-1920s, but many of its irrational features remained. The concerned mataqali head might still want a 'little something' to agree to the lease, and he might also play one potential tenant against another. Sometimes, even bribery did not work, for there was no guarantee, after the chief had approved, that the District Council or the government would approve the lease. Of course, the tenants wanted the best land, which meant that undesirable parcels remained unused. This problem attracted attention in the 1930s because Indians were moving steadily into agriculture. The CSR was also keen to stabilise land leasing procedures to ensure the expansion of sugar cane cultivation. As Sir Philip Goldfinch put it, 'any sign of the 'dog in the manger' attitude on the part of the landowners must be obliterated with a firm policy of the Crown.' If Fijians did not themselves cultivate the land, they must lease it to those who would ${ }^{25}$ And there was pressure from outside, principally from the Government of India, which reminded Fiji in 1935 that the colony's well-being 'must largely depend upon a satisfactory adjustment of [Indians'] rights and opportunities in relation to agricultural land. ${ }^{26}$

Fijian leaders were aware of these pressures. They accepted that improved leasing arrangements would benefit them as well. The colonial government, too,

23 Fiji Times, 3 November 1938.

24 There was already in existence a Child Welfare Program for the Fijian people.

25 CSO conf. 37/4/26 CSO F37/98.

26 CSO F37 /98. 
realised that it could no longer procrastinate, with the Governor telling the Great Council of Chiefs in 1936 that he would take a greater role in the 'stewardship of native land.' Ratu Sukuna told the Great Council of Chiefs in 1936:

We cannot in these days adopt an attitude that will conflict with the welfare of those who like ourselves wish to live peacefully and increase the wealth of the Colony. We are doing our part here and so are they. We want to live; they do the same. You should realise that money causes a close inter-relation of interests. If other communities are poor, we too remain poor. If they prosper, we also prosper. But if we obstruct other people without reason from using our lands, following the laggards there will be no prosperity. Strife will overtake us, and before we realise the position, we shall be faced with a situation beyond our control, and certainly not to our liking...You must remember that Fiji today is not what it used to be. We are not the sole inhabitants; there are now Indians and Europeans. ${ }^{27}$

This conciliatory attitude, born of pressure and necessity, resulted in the drafting of the new Native Lands Ordinance in 1937 and its promulgation three years later. The responsibility for the leasing of all native land was placed in the hands of a new statutory body, the Native Lands Trust Board, providing for the reservation of sufficient land to meet the future needs of the Fijian people. With that, the land question was settled for more than a generation.

Elections for the Legislative Council under the new Letters Patent were held in August 1937. As expected, the Governor nominated K.B. Singh to the Council. The second nominated member was Said Hasan, a Punjabi Muslim lawyer who had recently arrived in Fiji. For the three remaining elected seats, there were strict qualifications both for voters as well as candidates, including a two year residency requirement, a knowledge of English, and a net income either of £120 from business or professional occupations or $£ 150$ from land. Indian voters had to be over 21 years, with 12 month residency in the constituency, literate in either English, Hindi, Urdu, Tamil, Telegu or Gurmukhi, owning freehold or leased land of an annual value of $£ 50$ or more or a net cash income of $£ 70$. Needless to say, these provisions effectively excluded the majority of the Indians from voting because land was held in the name of one person, usually the father, and few had separate disposable income.

Vishnu Deo was elected from the Southern division and Tularam from the North. The Indian candidate for the North-western Viti Levu constituency was A.D. Patel, who had by this time emerged on the scene as a forceful and eloquent speaker and advocate for the rights of the Indian community in Fiji. 
Nonetheless, he was defeated by Chandrasenan Chattur Singh, who polled 671 votes to Patel's 651, 66 votes being invalid. Chattur Singh was a law clerk in the firm of D.C. Chalmers in Nadi, and not Patel's own law clerk as is widely believed. Patel's defeat caused great surprise. Patel was the 'official' candidate of the Arya Samaj, while Singh claimed to be its 'unofficial' candidate, although I have been told that the Arya Samaj neither officially nor unofficially endorsed anyone for Legislative Council elections, not even Vishnu Deo (Patel's nomination paper was signed by two Arya Samajis, Randhir Singh and R. Prasad, while Singh's were signed by four Samaj leaders Hardayal Sharma, Ori, Motichand and Shiu Prasad). Why did Patel lose the election?

There were several reasons. Patel's opponent, Chattur Singh, was a wellconnected Ba resident. Partly educated in New Zealand, he had travelled in the United States, Europe and India, and for a while was doing business in Madras. His elder brother, Parmanand Singh, was one of the three Indian elected members who had walked out of the Legislative Council in 1929. He was also the president of the Ba branch of the Indian Association (Patel was its national president). Singh, then, was the local boy who had made good. This worked in his favour, for the Fiji-born, India-born issue was raised in the election. One of Patel's remarks was twisted and used against him. In attempting to highlight the plight of the Indians, and the inhumanity of both the colonial government and the Colonial Sugar Refining Company, Patel recalled how in the indenture days, some Indian women had to give birth in cane fields. His opponents publicised this as the remark of an arrogant India-born Gujarati who had insulted the local Fiji-born by suggesting that they were born in the cane fields!

Patel's Gujarati background did not help matters either although it is important to note that some influential Gujarati merchants publicly opposed Patel and supported his opponents. As already seen, the numbers of Gujarati arriving in Fiji had increased markedly in the 1930s. The new migrants moved into petty trading, hawking, shop keeping, and into tailoring, laundering, and jewellery making. Their industry and long hours of work earned them the wrath of their competitors. In post-Depression Fiji, the Gujaratis became visible symbols of an oppressive class. European businessmen, threatened by this challenge, albeit still a small one, to their dominant position in the economy, railed against these 'birds of passage' exploiting the country for their own ends. Some of their rhetoric was also echoed by non-Gujarati Indian traders and others who felt overwhelmed by the industry and enterprise of the new immigrants. As descendants of girmitiyas, the original migrants, they resented being overtaken.

Siding with European traders, they formed a Young India Society in 1937 advocating the total prohibition of immigration, and demanding more government inspection of the Gujarati trading practices and working habits. P. Anand Singh of Ba wrote to the government on 23 January 1937: 'There are 
certain undesirable types of immigrants; Fiji is full of such. These men refuse to admit in their social circle which in itself creates bad feeling; these traders refuse to employ local borns in service; they refuse to teach them any form of trade; they refuse to spend in Fiji; their god is money, and their interest in Fiji purely a matter of pounds, shillings and pence. Our troubles date from far back, and it dates back from the days when professional men arrived amongst us.' The petition was signed by two hundred North Indians. Expressing the same feeling, a North Indian law clerk wrote in 1935: 'The Indian Tailors, Barbers, Boot makers and Dhobis start work at daybreak and continue their labour until late hours at night. They take no rest; if they are not working with their front doors open, they are continuing their labours inside the stores. 'his unfair competition is not in the interests of the local Indians or Traders and the sooner these people are made to take proper rest, the better for the whole community. ${ }^{28}$ Hard work was being equated with unfair competition. The call to legally enforce 'proper rest' was a novel, strange idea. Such ideas would be amusing were they not presented with great seriousness, providing telling insights into the post-girmit Indian mentality.

There were, however, some legitimate complaints against the Gujarati traders and others like them. Often they charged exorbitant interest on money lending, sometimes as much as 37-40 per cent without compunction. The traders would take from the cash-strapped farmers' promissory notes up to an estimated value of goods they required between cane harvests. As soon as cane harvesting began, they would take action to secure the proceeds of the crop in repayment. The traders' words carried the day, for the farmers were often illiterate and kept poor records, if any at all, of their transactions. On top of recovering their loans, the storekeepers also demanded (and obtained) interest on those loans, which the promissory notes did not allow (BiyajNahin) And so they entered the vicious cycle of debt, legal costs and compound interests. Sometimes, however, the farmers themselves were to blame. As the District Officer of Nadroga noted in 1942: 'The farmers are often to blame for not keeping their promises to pay when cane harvest payments were made and now, of course, the storekeeper is having to get every penny he can settle with the bigger stores for the goods he has obtained for them. ${ }^{29}$ The suggestion was that the Gujarati storekeeper himself was a cog in a larger wheel which most farmers did not realise.

Resentment against the Gujaratis' thrift and industry led to the demand for a strict control of all 'free' immigration into the colony. Patel opposed that demand, which was directed principally at Gujarati and Punjabi immigrants. The proposed restriction on immigration 'was an unnecessary encroachment on the right of domicile of the Indians in the Colony,' he told a meeting at 
Lautoka on 19 December $1937 .{ }^{30}$ Why should these people be singled out for discriminatory treatment when there was no similar demand for the curtailment of European immigration?, he asked. What is good for the goose should be good for the gander. The Gujaratis and others were repatriating money to their families back in India, but that was a minuscule amount compared to what the big European firms, such as the CSR, were repatriating to their respective home countries. How would the Indians be better served by the Europeans running the economy? If the Gujaratis were birds of passage, so, too, he said, were the Governor and the European civil servants. 'It is stupid to raise the question of imported and local Indians,' Patel told a political meeting at the Crown Theatre in Lautoka in June 1937. The real criterion for election should be ability, not one's cultural background or how long one had been in Fiji. A month later, he told a meeting in Namoli that he did not want to go to the Legislative Council as a representative of the Gujaratis, but as a representative of the whole Indian community. ${ }^{31}$ S.B. Patel made the same point, adding that A.D. was the best candidate for the job. Chattur Singh himself agreed. Patel was a good man but his 'extremist' stand on issues could lead to his deportation, just as Manilal had been deported in 1920. Fiji needed people like Patel, but not in politics! The best thing, Chattur Singh argued, would be to send him to the Legislative Council and keep Patel in the broader non-political arena, thus killing two birds at once.

Ironically, not all Gujaratis supported A.D. Patel. The most influential of them all, Appabhai Patel, the acknowledged leader of the Fiji Gujaratis, opposed Patel, and, according to some sources, urged Indians to vote for Patel's opponent, Chattur Singh. The exact reasons for Appabhai's attitude are not clear, though oral evidence points to two factors. A.D. Patel was not duly deferential to Appabhai's status and influence and did not seek his patronage to establish himself in Fiji, which, it is said, affronted the elder Patidar. Appabhai was also probably unhappy with A.D.'s personal lifestyle. His marriage to Patricia Seymour, and reports of A.D.'s marital infidelity, offended Appabhai's sense of the proper order of things. A.D., in Appabhai's view, was not behaving as a well educated Patidar should. Patel had also earned the wrath of the Muslims who were told by Said Hasan to vote for Chattur Singh. The main cause of the rift was Patel's strong public stand against nomination. Some prominent Muslims, as we have already seen, were opposed to the elective principle. Chattur Singh, too, was opposed to nomination, and had petitioned the government to that effect. But Patel was seen in a different light, articulate, forceful and uncompromising. In this assessment, they were right.

30 See also Fiji Times 3 Nov. 1938

31 CSO 51/54/1. 
By 1937, Patel had firmly established himself in Nadi. His residence there influenced the future course of his public career. Nadi lay in the heartland of the sugar cane belt of Western Viti Levu. Nadi, Patel said, was the 'sugar bowl' of Fiji. It drew Patel into the farmers' struggle against the CSR, as we shall see in the next chapter. Here, we consider another distinguishing feature of Nadi which moulded Patel's work. Nadi was the cultural centre of the South Indian community, which provided the initial political base for A.D. Patel. For more than two decades, Patel acted as the Legal Advisor of the Sangam, the umbrella cultural organisation of the South Indians, managed its schools and represented the community's concern to the government. Patel's involvement in Sangam's affairs aroused suspicion among many about his 'real' motives: was this simply another ploy by a cunning lawyer to use the South Indians to advance his political career? Certainly the government thought so. The Secretary of Indian Affairs wrote in 1937: 'It appears that Mr A.D. Patel has political aspirations and is endeavouring to popularise himself among the South Indian people.' ${ }^{32}$ This is a predictable indictment, for any Indian leader who challenged the colonial order was dismissed as 'ambitious,' 'extremist,' or 'disloyal.' There was more to the story though than simply naked ambition; in truth, it was a confluence of circumstances that drew Patel to the South Indian community.

The South Indians were the most disadvantaged cultural group in the Indian community. Darker skinned people of Dravidian stock, they bore the full brunt of North Indian cultural prejudices. Some Indian committee schools in Western Viti Levu refused to admit South Indian children. Socially isolated and economically down, they counted for little in the social and political agenda of Fiji Indian leadership, which was embroiled in deep religious and cultural disputes. The intra-communal, Hindu-Muslim, Sanatani-Arya Samaji disputes had contributed to Patel's defeat, and there was no sign of these destructive tensions dissipating anytime soon. Their absence among the South Indians attracted Patel to that group. Sangam, which means confluence, was a broadbased, inclusive organisation. Its flag carried the Christian cross, the Muslim star and crescent and the Hindu word 'Om.' Its schools were open to children of all groups and denominations.

The founder of the Sangam was Sadhu Kuppuswamy, a man of high moral and spiritual discipline imbued with the spirit of sacrifice. ${ }^{33}$ Born in 1890 into the Balija caste in the village of Konoor in South Arcot (Tamil Nadu), Kuppuswamy came to Fiji as an indentured labourer in 1912. After serving his indenture at Yalandro in Tavua, he settled in Raki Raki. It did not take Kuppuswamy long to realise the enormous social, cultural and moral problems facing the South

33 Others who played the leading role in founding Sangam, according to A.D. Patel, were M.N. Naidu, Arunachalam Pillay, K.S. Raman and Jambulingam Pillay. 
Indians in Fiji. He was particularly concerned at the neglect in the teaching and learning of South Indian languages, Tamil, Telugu and Malayalam. Without language and culture, people were as good as dead, he believed. The few European missionaries who worked among the Indians compounded the problem. Kuppuswamy wrote in his diary: 'These students who emerged from Mission schools were brainwashed to condemn Hinduism with the argument that the Hindus had innumerable gods and worshipped stones. Obviously these children did not know the depth of Hindu religion.' He believed that 'colonial rule will continue to be perpetuated endlessly in the absence of consciousness of freedom and self-dignity. Mother tongue, culture and traditions will die unless protected.' Patel agreed completely As he said on 12 November 1947:

Peoples' sentiments and feelings will have to be respected and I might sound a note of warning that if I had choose between the extermination of my culture and traditions and self-extermination, I would choose the latter. Without my culture and tradition, I am nothing. I am not a human being, I am merely a beast; and that is not the sort of education we are willing to receive at the hands of the Education Department. ${ }^{34}$

To protect and promote South Indian culture, the Sangam built temples throughout Viti Levu, organised pujas and festivals and held night classes for adults. Even newspapers in Tamil and Telugu were printed. In 1930, the first Sangam primary school opened its doors, and Sadhu Kuppuswamy invited Patel to become its general manager. Patel also found his own philosophy compatible to the Sadhu's, which strengthened the bond between the two men. Kuppuswamy worshipped Ramana Maharishi, Ram and Krishna and Sarada Devi, but was a very keen devotee of Swami Vivekananda (1863-1902), whom A.L. Basham has described as 'a splendid speaker of great spiritual power and personal magnetism. ${ }^{35}$ Vivekananda was one of Patel's two idols, the other being Mahatma Gandhi. Vivekananda's message, which echoed the philosophy of his spiritual master, Sri Ramakrishna, was that 'each man was potentially divine, and so should both work to unleash the infinite power within himself, and should help other men to do the same.' ${ }^{36}$ 'If you cannot see God in the human face, how can you see Him in the clouds,' asked Vivekananda, 'or in images made of dull, dead matter, or in mere fictions stored of your brain? I shall call you religious from the day you begin to see God in men and women and then you will understand what is meant by turning the left cheek to the man who

34 Legislative Council Debate.

35 Basham, 1959, 483.

36 Theodore de Bary, 1964, 647. 
strikes you on the right. ${ }^{37}$ Both Patel and Kuppuswamy shared the view that the noblest life was that which was devoted to social service, and that social service itself was a religious duty.

They also shared Vivekananda's great pride in the heritage of Indian civilisation. The Sadhu and the Sangam had the vision, but lacked the resources to realise them. Foremost among the problems they faced was the paucity of vernacular material in the three principal South Indian languages and suitably qualified teachers to teach them in the primary schools. In mid-1936, M.N. Naidu, the Sangam president, wrote to the Ramakrishna Mission in Calcutta seeking its assistance. In response, the Mission sent one of its senior monks, Swami Avinasananda, on a fact-finding mission to Fiji. He arrived in the colony in May 1937. The Swami was a striking figure and a dominating personality: tall, bearded, friendly, English-speaking former principal of the Surat National College, who had given up his academic career to join the Mission.

Patel and the Swami took to each other immediately. Patel recalled: 'He was a dreamer, an idealist, a visionary, and yet he was a determined worker who took delight in becoming a pioneer and breaking new ground.' ${ }^{\prime 8}$ The Swami travelled around the country and impressed upon the people 'the need for welding the Sangam into a well-united centralised organisation running under the care and guidance of the Ramakrishna Mission.' Some people wanted to merge the two organisations but, according to Patel, the Swami 'thought that the time was not ripe and the people were not ready to justify the Mission in opening a branch in Fiji.' Instead, the Swami suggested, and it was agreed, that the Sangam become an affiliated body of the Mission. The day this decision was reached, the Swami went to Patel's house at two o'clock in the morning to tell him the news and to ask him to become the general manager of the Sangam. 'Couldn't you have come in the day time, instead of taking the trouble of coming at this hour of the night when the graves give up their dead and ghosts walk about?' Patel asked jestingly. The Swami retorted, 'I don't believe in leaving anything till tomorrow which I can do today, Ambalal.'

Avinasananda returned to India in February 1938, but he continued to keep a watchful eye on Fiji. When the government procrastinated, he wrote to Patel in October 1938: 'I would request you to seek an interview with the Governor and ask him squarely whether he means to stand by the public and solemn pledges and promises made by his predecessor, or is he going to allow the narrow-minded, spiteful officials to obstruct and nullify the concessions made to us.' The man of the cloth did not mince words. Patel admired the Swami's feisty fighting spirit. The Swami's visit and his persistence paid dividends

37 de Bary, 1964, 648 .

38 See also Pacific Review, 10 January 1957. 
for the Sangam. After initial hesitation, the government accepted the Swami's suggestion that the Sangam be formally registered and given legal status. This was partly because the officials were impressed with Avinasananda, whom they called 'an outstanding figure among Indian religious workers,' 'undertaking very desirable religious and social work among the Indians,' and the Sangam 'a most worthy and progressive Indian Association. ${ }^{39}$ Strike while the iron is hot, Avinasananda told Patel, who immediately drew up the papers to have the Sangam registered as a limited liability company without the addition of the word limited. The Sangam was thus registered on 31 October 1937. Patel also persuaded the government to exempt it from the ordinance's clause limiting land ownership for such companies to two acres, and permitting it to own up to one thousand acres. In a letter he wrote to the Secretary of Indian Affairs on 28 November 1938, Patel made further requests: getting the Sangam representation on the Board of Education, importing teachers from India, introducing vernacular languages as an option to Hindi in teachers' examinations, providing for the teaching of vernacular Indian languages at the Natabua Teachers Training School, and seeking building grants and other facilities. ${ }^{40}$

Governor Sir Arthur Richards was sympathetic to the cultural and educational needs of the South Indian community. He told the Legislative Council in 1937:

For many years the Sangam has shown a keen interest in education and it has established its schools at considerable financial sacrifice in different parts of the Colony. The Sangam has frequently approached Government in the past with a request for facilities for the teaching of South Indian children in the mother tongue but, owing to the difficulty of finding suitable teachers for other Indian languages, the Government has been obliged to declare Hindi the medium of instruction in Indian vernacular schools. It is now intended that, in selected areas where Indian communities, whose mother tongue is a language other than Hindi, are prepared to establish schools in which their children can be taught for the early stages of their education in the mother tongue, Government will encourage and assist them in their endeavours. In this connection the Government is now considering proposals for the establishment of a cultural centre for Southern Indians at Nadi, where it is expected that teachers competent to teach Southern Indian languages may be trained for the future. Both the Director of Education and I are in sympathy with these aspirations and I have undertaken to give practical effect to this sympathy at an early date. ${ }^{41}$ 
Richards left the colony soon afterwards, and his successors did not honour his promise. But the government did agree to pay the cost of bringing two South Indian teachers from India to teach in Sangam schools. The first of them, N. Ramakrishnan, arrived in 1939.

The Sangam's insistence on the teaching of South Indian children in their own mother tongues was an integral part of its larger project to preserve the cultural integrity of the South Indian community. In a speech Patel prepared for Sangam leaders welcoming Governor Sir Harry Luke in 1939, the reasons were explained:

Our Society has been working in Fiji for the past sixteen years for the uplift and cultural renaissance of our Countrymen in Fiji. Through force of circumstances we who lay claim to one of the oldest if not the oldest culture of the world found ourselves after a stay of fifty years in this Colony a community who had lost all their culture and traditions. The Education of the people was neglected during that era of Fiji's History and consequently whatever material benefits may have been gained by our countrymen were offset by the loss of social traditions and cultural background which is so essential to the life of any civilised community. Though the traditions were forgotten the desire for Education and cultural uplift lived in the hearts of these pioneers and it was out of this desire that this Society was born. Men who, though illiterate, had passed through the sternest school of life and realised that their children ought not to go without the blessings of Education. ${ }^{42}$

This was a powerful plea from a community shouldering the dual burden of colonial neglect and North Indian prejudice. Its very survival as a cultural entity was at stake. But this predicament evoked little sympathy among the other Indians. They were happy to have Hindi taught as the lingua franca of the Indian community, and understandably so, as it worked to their advantage. They also wanted more instruction in English. In this instance, however, what was good for the goose was not good for the gander. Or, as the Sangam leaders put it, learning another language before one's own was like putting the cart before the horse. Patel's involvement in the Sangam's affairs deepened with the arrival in 1939 of Swami Rudrananda, sent to the colony by the Ramakrishna Mission. As already mentioned, Rudrananda remained Patel's closest life-long friend in Fiji, his spiritual counsellor and confidante and his most dependable ally in his political struggles.

By 1939, Patel had been in Fiji for more than a decade. These were tumultuous times both for the Indian community as well as the colony as a whole. The Indian community was emerging from the shadows of indenture and demanding its due place in the colony that was now their home. The colonial government resisted their challenge and succeeded in arresting social and political change. The 1930s were also personally unsettled times for Patel. He had entered the political stage and made his mark, but narrowly failed to get elected to the Legislative Council. It was the first of three electoral defeats for him. Still, tumultuous as the 1930s were, even more unsettled times lay in the future. 


\section{Chapter 4: Company and Kisan}

The relations between the Company and the growers was strong reminiscent of barons and serfs during the Middle Ages. They had to take what was given to them and be thankful for the small mercies whether they liked it or not.

A.D. Patel, 1943

I am convinced that I was taking up a true and just cause and I am convinced that the stand I took and the advice I gave to the growers was right and I am proud of the part I played in that dispute.

A.D. Patel, 1945

On 12 January 1938, Padri Mehar Singh, Saiyyid Latif Shah and Pandit Ajodhya Prasad went to A.D. Patel's office in Nadi. ${ }^{1}$ They had just formed a farmers association, the Kisan Sangh, and wanted Patel to become one of its leaders. They failed to persuade Patel. According to Prasad, Patel refused to become involved. Confronting the CSR, Patel reportedly said, was like battering one's head against the mountains of Sabeto. There was no organisation in Fiji which was strong enough to confront the Company, said Patel, and urged the three men to go home and forget about their foolish project. When Shah persisted and reminded Patel of how bad leadership and ignorance of the law had cost Indians dearly in the 1920 strike, Patel, according to Prasad, reportedly said unbelievably: 'I'll gladly pull the trigger if I find the government pointing its machine gun towards Indians.'

Unsuccessful in their mission, the three men left Patel's office and went to a shady spot under a tree nearby to ponder Patel's motives. Patel, they concluded, was a self-seeking, double-faced man, who was scared witless of the power of the CSR. Why else would anyone think that the CSR was solid and immovable like the mountains of Sabeto? Patel was all show and little substance, said Shah, a heartless coward. Prasad offered another explanation. Patel, he said, was a Gujarati lawyer motivated solely by greed. He wanted the farmers to remain disunited so that the Gujarati merchants, who dominated the rural retail trade, could continue their stranglehold over the Indian farming community.

A.G. Sahu Khan, Indian assistant to the District Commissioner Western and sonin-law of the Kisan Sangh president M.T. Khan, agreed. What really motivated Patel, he privately informed the government in 1941, was the interests of the 'moneylenders and the Gujarati trading community all of whom hear the

1 This is from Prasad, 1962, 63-64. 
sounding of their death-knell in the cooperation and collaboration between the Sangh and the Company.' These groups, he continued, 'dread the cooperative credit and cooperative consumer societies which the leaders of the Sangh have in view and feel that such schemes will be much facilitated as a result of the CSR Company's cooperation and friendliness.' Patel was always dabbling in 'politics of the extreme type,' Sahu Khan continued, motivated by nothing more than 'revenging himself upon the people for the political defeat inflicted upon him at the election before. ${ }^{2}$ Another government agent, N. Ramakrishnan, who had been dismissed from teaching at the Nadi Sangam School of which Patel was the general manager, wrote similarly, accusing Patel of playing one cultural or religious group against another. 'Iago would have paled into insignificance before him,' he said.

Stories of Patel's Gujarati greed, his vain political ambition, and his ruthless manipulation of the genuine grievances of the ignorant cane farmers for his own ends form a part not only of the colonial record, and even some scholarly accounts, but also of the folklore in parts of the cane belts of western Viti Levu. I have met men who, fifty years later, are still adamant that Patel was nothing more than a wolf in sheep's garb, and hold him responsible for divisions in the Indian cane farming community. Others, equally passionately, hail him as a hero and blame mismanagement, poor leadership and strategic blunders for the Kisan Sangh's failure. The documents on the sugar industry included in the companion volume of Patel's speeches and writings might usefully be consulted to get a better, more informed account of the affairs of the industry and Patel's role in them.

Sugar cane politics clearly make a complex and controversial story, its labyrinthine patterns nearly impossible to decipher. In the circumstances, perhaps the best way to assess Patel's role in the Fiji sugar industry, and his opponents' criticism of it, may be to evaluate his actions in the context of the times, to look at the structural impediments he encountered and the solutions he proposed. Among other things, it would involve a discussion of the power of the CSR, the attitude of the colonial government and the social and cultural divisions in the Indian community itself. Was Patel the heartless villain that his opponents said he was?

To answer that question, it is necessary first of all to look at the structure of the Fiji sugar industry. That industry was dominated by one company, the Colonial Sugar Refining Company. ${ }^{3}$ Formed in 1855, the Company came to Fiji in 1880 , at the invitation of the colonial government which had decided that the

2 See A.G. Sahu Khan's comments in CSO F51/5. But about Khan, District Commissioner J. Judd wrote: 'Mr Sahu Khan makes little effort to conceal his sympathy for the Kisan Sangh and his antagonism to the Maha Sangh.'

3 For the literature on which this is based is best summed up in Moynagh, 1981. 
future prosperity of the recently acquired colony lay in large-scale plantation agriculture, with sugar cane as the main crop. Initially one among several sugar refining companies in Fiji, the CSR, by 1900, had emerged as the largest miller of cane and employer of Indian indentured labour. After 1926, when it bought out the Penang Sugar Mill, it became the sole miller of cane in Fiji, a giant monopoly with corresponding political and economic influence in the affairs of the colony, an influence which the Company was not averse to wielding to bend government policy to its ends when it could.

The end of the indenture system in 1920, which caused a severe shortage of labour, heralded another change in the sugar industry. Until then, the CSR had bought substantial amounts of cane from European contractors or big Indian settlers, its own role as the sole producer of cane with Indian indentured labour having declined substantially by the turn of the century. In 1924, the CSR began what came to be known as the smallholder system. ${ }^{4}$ By this scheme, the Company divided its estates into 10-12 acre plots and leased them out to prospective Indian tenants. Once begun, the process of subdivision was rapid. Thus, in 1925, the CSR cultivated 33,679 acres of cane, the European planters 4,446 acres, tenants 6,905 acres and independent contractors 19,933 acres. In 1941, however, the CSR cultivated only 3,153 acres, European planters 161 acres, Indian tenants 46,521 acres, and independent contractors 42,793 acres. $^{5}$

From the CSR's point of view, subdividing made good economic sense. It resolved the question of labour supply, and by involving the Indian tenants in cane growing in their own right, subdivision, so it was hoped, would deepen their interest in and commitment to the welfare of the industry as a whole. United they - the Company and the Kisan-stood to prosper; divided, both would perish. That was the rhetoric, the reality was different. For when the Company divided its estates, it naturally had no intention whatsoever of weakening its control over the industry or its Indian tenants. In the agreements it signed with the tenants, the Company made it perfectly clear who the master was and who the servant. According to the agreement, the CSR alone was to decide what varieties of cane it would permit to be planted. The tenants were told that 'crops must be tended and harvested to the complete satisfaction of the Company' The Company was also a large landlord which could terminate any lease with its tenants if it disapproved of their cultivation or harvesting techniques. It could unilaterally terminate any lease on a year's notice or 'in the event of legislation being passed limiting its freedom of action on the said land or otherwise affecting the conditions under which it carries on its operations.' It was a not-too-subtle message to the government to watch its steps in its dealings with the Company.

4 See J.C. Potts, 1962-63.

5 Narsey, 1979, 5:106. 
The CSR had good reasons to keep a firm hand on the leash, among them the smooth functioning of the sugar industry. But times had changed. Its Indian tenants were not meek girmitiyas who could be easily forced to acquiesce, but people who were acutely conscious of their rights and now unafraid to seek them. The CSR failed to appreciate the change. As Stuart Reay, the government's labour officer, noted as late as 1941, 'in the sugar districts, the word coolie is still frequently heard, and where an Indian who does not abase himself is resented.' ${ }^{6}$ Unfortunately for the CSR, the days when it could demand and receive complete subservience were long over. The time had arrived when it would be better for the CSR 'to conduct its business with tact and firmness rather than with firmness alone. ${ }^{\prime 7}$ Now, the Indian farmers had articulate leaders of their own who could, and did, speak up on their behalf in the Legislative Council and even communicated with powerful pressure groups outside the colony.

Nonetheless, the CSR still resisted the pressure to grant concessions. Throughout the 1930s, for instance, it had opposed the introduction of trade union legislation in Fiji. In the early 1930s, the Colonial Office in London had encouraged the colonies to enact trade union legislation 'in advance of the need for it, rather than defer action until the matter may perhaps have become the subject of political controversy. ${ }^{\prime}$ Sir Murchison Fletcher was opposed, telling the Colonial Office in April 1931 that such a legislation could be used by the ambitious politician 'for the furtherance of his own mischievous purposes.' It might, he said, 'suggest to him the opportunity of uniting by intimidation or cajolery ignorant and disaffected persons under the guise of a trade union, which would be duly registered. ${ }^{9}$ When the Colonial Office asked Fletcher to reconsider, the Governor told London in May 1932 that he would wait until he got the CSR's response. The Company agreed with the Governor. F.C.T. Lord, its attorney in Fiji, said that any trade union legislation 'would be a grave mistake, and may be fraught with serious consequences to the future welfare of the colony, with its varied races and interests.' There was an identity of interest between the Company and the government, Lord hinted. Such legislation would 'sow the seeds of discord and industrial strife,' he advised, and could conceivably be the first step in the demand for more legislation for arbitration courts, wage boards, and the like. Faced with these views, the Colonial Office baulked, after being assured by the government that the matter would receive attention 'if and when there is any indication that wage labourers in the Colony are disposed to form associations for the protection of their legitimate interests.'

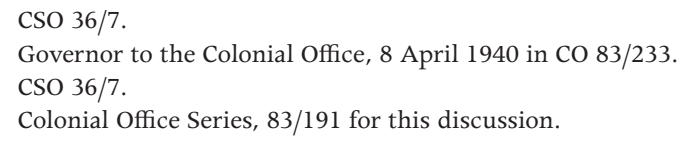


The Indian labourers and farmers had been agitating for protective trade union legislation for some years. The subject was raised at virtually all colony-wide conferences of Indian leaders in the late 1920s and 1930s. But rather than wait for the government to provide leadership, the cane growers took the lead and formed an association of their own, the Kisan Sangh. The new association came into existence at $\mathrm{Ba}$ in November 1937, after months of secret midnight meetings in western Viti Levu to avoid detection and persecution by the CSR. The main force behind the formation of the Sangh, and its founding general secretary, was Ajoydhya Prasad, an India-born school teacher who had come to Fiji in 1926. Mohammed Tawahir Khan, a wealthy Lautoka trader, became the inaugural President. Delegates from all the major sugar areas of Fiji were coopted into a thirty-two-member executive committee of the association. General dissatisfaction at the CSR's attitude toward the growers lay behind the formation of the Kisan Sangh. As things stood, both the independent cane growers as well as the CSR tenants were completely at the mercy of the Company. ${ }^{10}$ They could not plant vegetables or keep poultry or cows on CSR land; the Company alone could determine the varieties of cane the farmers could plant; and the Company could demand labour from its tenants for work on its tramways and in the mills and fields.

The Sangh wanted these excesses corrected. ${ }^{11}$ It wanted the payment of a flat rate of $16 / 6$ per ton weight of cane supplied rather than the percentage of cane sugar system (p.o.c.s.) which the farmers hardly understood. It demanded an increase in the purchase price of cane from the CSR, and opposed the fallowing of land on Company leases. The growers themselves wanted to decide whether they should plough the field after the first ratoon rather than as the Company decreed. It wanted to appoint its own men to check accounts and the sugar content of cane at weighbridges. And it wanted to have a say in appointing sirdars. In short, the Sangh wanted to promote the growers' interests by checking the excessive power and influence of the CSR. ${ }^{12}$

Starting the Kisan Sangh was not easy. One important obstacle was the intransigence of the CSR. It simply refused to recognise the Sangh as an organisation representing the cane growers. ${ }^{13}$ As the District Commissioner Western wrote in January 1940, 'The Company will not have anything to do with the Kisan Sangh.' The Sangh's correspondence went unanswered. The Company went further. It barred Kisan Sangh officials from entering its property, which included its leases to the Indian tenants. It even threatened to evict those of its tenants who associated themselves with the Sangh in any

10 See McGusty's report in CSO CF $51 / 29$.

11 See CSO $51 / 29$ (confidential) for this and other related affairs.

12 CSO CF 36/1/15.

13 For CSR's attitude see Sir Philip Goldfinch to Governor, 28 February 1940 in CS051/29. 
way. Some government officials were sympathetic towards the farmers and quietly pleaded with the Company to change its attitude. Wrote Stuart Reay, the Commissioner of Labour, in 1941: 'At the head of the Association are shrewd and able men inspired apparently by strong convictions and untainted by motives of personal gain. The unity and strength of the Sangh, the quality and motive of its 'led trade unions or planters associations in Mauritius. ${ }^{14}$ This is how the Governor himself described the Company's attitude to the farmers in a note to J.E. Shockbargh of the Colonial Office: 'We have fixed the price of cane at what we consider to be a just and reasonable level, and we have laid down certain conditions which we require you to accept. We are not prepared to enter into any agreement on the subject and we expect you to rely on the Company's good faith.' ${ }^{15}$ When the government hinted that it might introduce workmen's compensation legislation, minimum wages and an arbitration tribunal, Sir Philip Goldfinch, the CSR General Manager, threatened to personally visit London to oppose the measures.

Finally, in 1941, the CSR yielded but only when it realised that both the Fiji government and the Colonial Office would recognise the Sangh's existence and authority among the growers anyway. The Governor wrote to the CSR's attorney in Fiji, Irving King, in March 1941: 'In the opinion of the Government, there is no longer any doubt as to the permanent nature of the Kisan Sangh as an industrial association representing the great majority of cane growers, and as such, it is a body which must be given formal recognition. ${ }^{16}$ Within three years after it was established, official sources estimated that close to 75 per cent of the cane growers had joined the organisation or were otherwise sympathetic to its goals. Many debt-ridden farmers were attracted to the Sangh's proposal for a farmers' cooperative and trading stores in the cane belts of western Viti Levu. These ventures, they were promised, would free them from the clutches of rapacious moneylenders and Gujarati traders.

For a while, the prospects for the Kisan Sangh looked bright as a truly representative body of cane growers. There was unity among the farmers and a resolve as well to improve their lot through mutual cooperation. And the Sangh seemed able to deliver on some of its promises. It was able, for example, to negotiate a ten-year contract with the Company, which in the circumstances was no mean achievement. For its part, the CSR agreed to meet some of the farmers' demands, such as improving the delivery of fertiliser, reducing interest on advances to 4 per cent, allowing a farmers' representative to be present at the mill weighbridge to check the weight of cane. Farmers were given written receipts for cane proceeds, and Company tenants were allowed to grow some

14 CSO 36/7.

15 CSO 51/29 (confidential).

16 CSO 36/7. 
food crops on their leaseholds. The Kisan Sangh was given the responsibility for appointing sirdars, and agreed to cooperate with the Company to settle disputes among farmers, increase the efficiency of the harvesting program, and persuade its members to bear losses that occurred in the industry. By 1943, the Sangh had a limited capital of $£ 10,000$. In August 1940, 72 per cent of cane growers in the Northern and Western division had joined as members, and in March 1941, the financial membership of the Sangh stood at nearly 3,000. ${ }^{17}$ Kisan Sangh had made an impressive start.

But soon problems set in. One reason was that people like Patel had not joined the organisation. Whether Patel refused because he was an agent of the Gujaratis will become clear in due course, but here it is necessary to note Patel's distrust of people like Ajodhya Prasad and M.T. Khan. In the 1937 elections, both of them had campaigned for his opponent, Chattur Singh. Patel could not be trusted, they had said, because he was a Gujarati; to now to seek this Gujarati's support for their organisation, seemed ironic, not to say suspicious. Patel also opposed the Kisan Sangh's seemingly cosy relations with the CSR which developed after the Sangh was formally recognised by the Company. Whereas the Sangh saw a community, even an identity, of interest between the growers and the millers, Patel emphasised the differences:

We must recognise the fundamental clash of interests which exists between the CSR Company and people and Government of Fiji. It is to the Company's interest, being an outside concern, to produce sugar here in Fiji as cheaply as possible and to sell it abroad as dearly as possible, and the margin between the two is the margin of profit that the Company pays to its shareholders in Australia. They have no interest in this Colony as far as marketing their product is concerned, therefore the buying power of the people of the Colony is immaterial to them. On the other hand, it is very, very material that there is no competition in the labour market, that they command their labour at the cheapest possible rate, that there is no competition in agriculture. ${ }^{18}$

A.D. Patel, however, was not the only prominent Indian leader who refused to join the Kisan Sangh. S.B. Patel, Vishnu Deo and Said Hasan were among other leaders who had kept their distance from the organisation. Indeed, after brief enthusiasm, some of the Sangh's own members left the organisation in dismay. Chattur Singh, the beneficiary of the Kisan Sangh's electoral support, wrote to the Governor on 16 July 1940 about the 'harmful' activities of the organisation and sought to 'have the Kisan Sangh declared an unlawful association for the duration of the war.' The organisation's members, he said, were similar 
to 'fifth columnists.' They allegedly assaulted those who refused to join their organisation, coerced people to sign papers in the middle of the night, set their opponents' cane on fire, and generally harassed them. Swami Rudrananda called the Sangh's tactics 'gangsterism.' ${ }^{19}$

Chattur Singh was one prominent Sangh supporter who had turned against the organisation. Another was Sadanand Maharaj, son of Badri Maharaj, a member of the executive board of the organisation and part of the Sangh delegation which had met the Governor on 22 May 1939. He told the Governor privately that he had doubts about the objectives of the Kisan Sangh but had joined it to counsel moderation. Maharaj had an agenda of his own, though: he wanted to be appointed a Justice of Peace. Maharaj's behaviour was not surprising; like so many others in his community then, and later, he was pursuing his own interests behind the facade of community interests.

There were others in the Indian cane growing community who were also disenchanted with the way the Kisan Sangh was conducting its affairs. Among them were many South Indian cane growers. Once the Sangh had gained the CSR's reluctant recognition, it had softened its stance toward the Company. That suited many Sangh members, many of whom were North Indian independent contractors who grew their cane either on native leases or on freehold land, and not as tenants of the CSR. As late comers to Fiji and to the sugar belt of western Viti Levu, many South Indians worked either as direct employees of the CSR or as its more vulnerable tenants. By and large, they were economically worse off than many North Indians. They were dismayed to see the Sangh moderate its stance. The fact that many North Indians looked down upon the South Indians, calling them 'bushmen' did not help matters. ${ }^{20}$ Many Punjabis were also unenthusiastic about the Kisan Sangh. This was partly because some of the Sangh leaders and their allies in the Legislative Council had opposed immigration in the mid-1930s. They and the South Indians felt that the Sangh was a well thought-out move by some prominent North Fijian leaders to capture important sectors of the Indian community. ${ }^{21}$

The first indication of a division in the cane growing community came in 1938, when Goldfinch visited Fiji. The South Indians, led by Swami Rudrananda and A.D. Patel, met him at Lovu, Lautoka. At that meeting they raised their concerns. For reasons of his own, Goldfinch was sympathetic. Among other things, the CSR agreed to help the Sangam by granting it blocks of land to build schools in western Viti Levu. With time, the gulf between the pro and anti-Kisan Sangh factions increased. To no one's surprise, in June 1941, five years after the

19 N. Ramakrishnan, administrative assistant based in Nadi, accused the Kisan Sangh of using 'terrorist methods.' See CSO CF2/19. Ramakrishnan was intensely anti-Patel.

20 CSO 51/29.

21 J.E. Windrum to D.C. Western, 24 August 1938, CSO 36/3. 
Kisan Sangh was launched, a rival growers organisation, the Akhil Fiji Krishak Maha Sangh, was formed in Nadi by some fifteen hundred farmers. Its legal adviser was A.D. Patel, and its leading members included Sadhu Kuppuswamy, M.N. Naidu, Swami Rudrananda, Tulsi Ram Sharma and Ratu Mela. The new organisation was launched after a dramatic attempt by Kisan Sangh members to prevent the formation of the new, rival organisation had failed. The meeting launching the Maha Sangh was held at the Nadi Sangam School. It was a shrewd tactical move by A.D. Patel, who was also the School's general manager. When the Kisan Sangh members tried to disrupt the meeting with alternative proposals and violence seemed imminent, a mele ensued. Exercising his authority as the general manager, Patel asked the police to eject the Kisan Sangh members from the school compound. He succeeded, but the move divided the farmers more than ever before and the bitterness of the division lasted for a long time.

Throughout this period, the late 1930s and the early 1940s, the plight of the farmers had been steadily deteriorating. The price of cane had fallen, and the farmers were deeply in debt. Then things took a turn for the worse with the outbreak of the Pacific war in 1942, dramatically increasing the price of most basic food items. Many Indian cane growers in the Western Division, particularly in the Nadi-Lautoka area, were evicted from their farms to create space for war-related work, such as the construction of barracks, supply depots and the airport. The displaced farmers approached the government as well as the CSR for help. Patel took up their case with the Company directly, but the CSR would not listen, and the government was powerless, perhaps even unwilling, to act. On 22 June 1943, Patel wrote to the Colonial Secretary. 'Ninety per cent of the growers do not wish to harvest cane/ he wrote, 'unless and until the price is raised to at least double the pre-war level.' He went on:

Considering the tremendous rise in the prices of livestock, agricultural tools and implements, exorbitant repair charges and almost prohibitive cost of harvesting coupled with the high cost of living, the Maha Sangh is of the opinion that unless the price of cane is raised, it is impossible for growers to carry on with sugar cane cultivation and they will have to by force of circumstances altogether give up cultivation of sugar cane and resort to crops which would ensure them a reasonable margin of profit and a decent standard of living. ${ }^{22}$

The government acknowledged the problem which, it said, was 'common to all sugar-producing colonies' and promised an enquiry 'which will be made [to ascertain] whether any remedial measures are contemplated.' A week later, it appointed a commission under the Conciliation and Arbitration Ordinance of 1941 to 'enquire into the demands of the cane farmers for an increase in the price 
of cane, and matters incidental thereto, and make recommendations thereon.' The commission was chaired by the Attorney General, and assisted by Hugh Ragg and Appabhai Patel. ${ }^{23}$ B.D. Lakshman, then a member of the Legislative Council and active in trade union politics, supported the appointment of the commission along with the leading members of the Kisan Sangh. By doing so, they hoped to get the government on their side, and perhaps the CSR as well, while at the same time cutting the ground from under the Maha Sangh. Perhaps they knew that the government would not appoint a court of arbitration under any circumstances, and so half a loaf was better than none. ${ }^{24}$

Patel and the Maha Sangh rejected the idea of a commission of enquiry altogether. A commission, Patel said, would achieve nothing except delay the resolution of the dispute. The CSR, which was based in Sydney, could not be compelled to produce its books in Fiji. Instead, Patel demanded a court of arbitration with the power to make binding recommendation. As he wrote in a Maha Sangh circular: 'We do not want an enquiry. What we want is conciliation or arbitration. A commission merely enquires. Aboard conciliates. A court arbitrates. Let the government give us a Board or a Court.' Patel was convinced that if all the facts were placed before an independent authority, the farmers' claims would be vindicated. Patel reminded the Governor of the promise he had made to the growers at Lautoka on 19 July, to set up a Board to bring about conciliation in the industry. He advised the Governor that if the commission failed, there was a provision in law to set up a Court of Arbitration. Many growers supported Patel, including a faction of the Kisan Sangh, led by Padri Mehar Singh.

The commission sat in various parts of Viti Levu throughout July, but farmers refused to appear before it, including those from Rewa led by Vishnu Deo and Said Hasan. Boycotted by the growers, hampered by lack of general public support and unable to accomplish much, the commission closed in early August. As we shall see later, the commission's findings vindicated Patel's suspicions and served to discredit those in the Kisan Sangh who had supported its appointment. Meanwhile, in August, a few farmers in Ba informed the District Commissioner that they wanted to harvest their cane but were being harassed by hooligans hired by the no-cutting gangs. Sensing an opportunity to break the strike, the government posted armed constables in the cane growing areas to offer protection to those who wished to harvest. The presence of armed constables heightened tension and imparted a racial overtone to the strike, reminiscent of 1921. Most of the constables were Fijians and the cane growers all Indians. Still, the government's presence failed to intimidate the growers, the majority of whom refused to harvest.

23 CSOCF $2 / 53$.

24 The early history of the strike is in CSO CF 36/1/15. 
The government then resorted to other measures. It declared sugar an essential food item and sanctioned a penalty for impeding its production. The Defence (General) Regulation of 1942 was amended to detain any one on the grounds of 'public safety, defence, the maintenance of public order, the efficient prosecution of the war or the maintenance of supplies or services essential to the life of the community.' This hastily devised piece of legislation was issued against A.D. Patel and Swami Rudrananda on 6 August, restricting their movement to within a radius of five miles of their homes in Nadi and further requiring the two to notify in person their movement to the police.

If the order was designed to intimidate Patel and Rudrananda, it failed. Patel responded in an 'Open Letter' to the Governor on 12 August. ${ }^{25}$ He reminded the Governor of his statement to the farmers at Lautoka on 19 July. At that meeting, the Governor had told the growers that as owners of their crop, they were not obliged to harvest it if they did not want to; they could do what they liked with it. He also reminded the Governor of the provisions of the Industrial Disputes Ordinance which could be invoked to resolve the dispute; appointing a commission of enquiry, which the farmers had rejected, was not a step in the right direction. The law provided, Patel continued, that if the commission failed, as it evidently had, the Governor was empowered to appoint a board or a court of arbitration. The Governor was also reminded that although the growers had been assured that Fiji was in constant communication with the Ministry of Food through the Secretary of State for the Colonies, months had passed and nothing had eventuated.

The detaining order, Patel said, was humiliating. 'When the head of a Government makes a Regulation in haste and punishes people even before any one has an opportunity of knowing what new Regulation he has made, such an act in our humble opinion loses all the respect and dignity that law is entitled to exact from the citizens and it merely becomes the will of a despot.' As a believer in the 'noblest ideals of democracy/ and the freedoms espoused by President Roosevelt, Patel continued, he and Rudrananda could not 'see our way to humiliate ourselves and report in person every day to the Police Station.' Both men, however, agreed to inform the government before they broke the order. The 'Open Letter' closed with a reminder to the Governor of Secretary of State Lord Moyne's White Paper on the trade union movement in the colonies and the responsibility of colonial governments to foster them. 'Our imagination is staggered and the words escape our lips: Is this [the detaining order] really the practical interpretation of Britain's New Colonial Policy?'

25 Quote from the 1943 strike file, compiled by Swami Rudrananda, which is in my possession; reproduced in the companion volume. 
This was quintessential Patel, standing on a principle and reminding the authorities that it was they who were breaching their own policies, not him. The news of the detaining order, and Patel's and Rudrananda's decision to disobey it, spread rapidly throughout Viti Levu, galvanising the farmers and rallying them behind the two men. Both Patel and Swami Rudrananda were brought to the Nadi court for sentencing on 12 August. Some 700 Indians converged on Nadi that day, as shops closed throughout western Viti Levu and prayer meetings were held. In court, Patel read a prepared statement once again drawing attention to the hasty manner in which the Defence Regulation had been amended. Although a regular subscriber to the Royal Gazette, he said, he had come to know of the amendment on the 10th, just four days after it had been gazetted. He was not an ordinary criminal, Patel reminded the court, but among other things, president of the Bar Association of Lautoka, President of the Indian Association of Fiji, President of the Indian Chamber of Commerce, and General Manager of the Sangam. He would not suffer humiliation. 'In such circumstances I believe that it becomes the duty of every self respecting citizen to disobey such an iniquitous, unmerited, arbitrary humiliating Order. ${ }^{26}$

For the crime of not reporting their movement to the police, the magistrate fined Patel and Rudrananda $£ 50$ each or one month's prison sentence in default. Both refused to pay, but the magistrate could not commit them to prison without the preliminary step of assessing levy and distress on their respective properties. It would take five days to issue the distress warrant, during which time they remained free. Before the five days were over, an anonymous well wisher, in fact S.B. Patel, paid the fine. In a public note, A.D. Patel rebuked S.B (without naming him) for putting both himself and Swamiji in an embarrassing position. Patel appealed his conviction on the charge of obstructing the cutting of cane. The Supreme Court upheld the appeal on the grounds that since it was not the legal duty of farmers to cut their cane, it could not be an offence to persuade them against it.

The government responded swiftly by amending the Defence Regulation to make it an offence 'to endeavour to induce any person not to cultivate or not to harvest any crop which has been declared by an Order of the Governor to be essential for the prosecution of the war, or essential to the life of the community.' One way or another, the government was determined to reclaim its authority. Times had changed. Two decades earlier, the government could exile Apolosi Nawai or issue a residential prohibition order against Manilal Maganlal Doctor without a second thought and without the fear of being challenged in court, which themselves were effectively under the government's thumb. In the 1940s, however, Fiji was no longer the isolated colony it once was. And Patel was not one to accept arbitrary orders without protest. 
The detention episode had another effect. It powerfully underlined the fact that whatever else it did, the government could not ignore Patel and his appeal among the cane growers. The public's outrage at his conviction was proof enough of that. It also effectively demolished the Indian administrative assistants' assessment of Patel as a selfish leader, an agent of the Gujaratis, who was using the Indian community for his own ends. Another view current at the time, and in some circles even now, was that Patel was deliberately prolonging the strike as an act of vindictiveness toward the farmers who had opposed him in the past. The longer the strike continued, the more debt a farmer was likely to descend into. Nothing was better for the Gujarati shopkeeper than the spectacle of farmers steadily descending into debt. Evidence points to contrary conclusions, suggesting that Patel and other growers' leaders worked extremely hard, often behind the scenes in private negotiations, to bring the sugar dispute to a speedy resolution.

On 21 August, Said Hasan, the Indian nominated member, called Patel from Suva to convey a message from the Governor. ${ }^{27}$ At the request of the Indian members of the Legislative Council, the Governor reportedly agreed that the counsel for the growers and the counsel for the Company (Patel and Sir Henry Scott respectively) should examine the Company's accounts. Whatever figure might be agreed between them for the cost of production of sugar would be accepted by the government and cabled to the Ministry of Food. The message was communicated to Patel by Superintendent Kermode. Patel travelled to Suva the following day (Sunday) and, accompanied by Hasan, met Scott in his chambers. Scott outlined the Company's position: the growers would have to begin harvesting before it would allow inspection of the accounts. Patel responded that 'the settlement of the dispute was the only way left open for getting the cane harvested quickly' Scott then arranged for a meeting between Irving King, the CSR attorney in Fiji, himself and Patel the next morning.

At that meeting on Tuesday in Scott's chambers, King rejected Patel's proposal. Patel told the two that 'we were there with a will to arrive at a settlement and that we could assure them that in dealing with the accounts they would find us reasonable.' King was unconvinced, and brought up another issue: examining the Company's accounts would take a few weeks as four mills were involved. Patel proposed to 'sit night and day' to save time. To prevent further delay, he suggested that Hasan could examine the accounts of the Rewa growers whose cane was crushed at the Nausori Mill, while he would do the same for the Lautoka area. The Lautoka figure, he suggested, might be accepted as the average for western Viti Levu generally 'as conditions of producing sugar cane were more or less the same in those districts' while the Nausori figure might

27 Based on 'What happened in Suva,' by A.D. Patel and circulated widely in the cane growing districts. In the Rudrananda file; see companion volume. 
be accepted as the mean for the southern districts. According to Patel, both King and Scott seemed favourably disposed towards this proposal, though Scott doubted whether the Ministry of Food would intervene to resolve the dispute in Fiji. Scott 'personally preferred that the sugar industry sank in Fiji rather than the already overburdened taxpayer in England [be] called upon to bear an additional burden for the sake of growers in Fiji.' Talks stalled when, after consulting the CSR, King reiterated the demand that harvesting precede any inspection of the accounts.

On 26 August, Patel was summoned to a meeting with the Governor, in the presence of the Attorney General, the Colonial Secretary, and B.D. Lakshman, the Indian elected member for north-western Viti Levu. The Governor restated the issues. 'The Company was not going to disclose its accounts and it was unlikely, in any event, for any agreement to be reached between the two sides on the figure for the cost of production. He would not appoint a Court of Arbitration because the CSR had its books in Sydney and it could take up to two years for an award to be given. The Governor said that he was 'prepared to stake my reputation on my belief that the CSR Company is not making a big profit.' The growers could refuse to harvest their crop, but he reminded the leaders that any interference in the harvesting of cane was now illegal. The Governor would appoint a commission of enquiry, and would even enlarge it to include representatives of the growers organisations. A Board of Arbitration was out of the question.

The Governor and his advisors thought that if Patel asked the growers to accept the commission, they would agree. They were mistaken. The growers themselves at mass meetings throughout Viti Levu rejected the idea. In a public letter, the Maha Sangh proposed on 6 September that the 'growers are immediately prepared to harvest and sell their cane to the Government who can make their own arrangements with the Company for milling it and give the growers a fair price that would cover the cost of production and a reasonable margin of profit commensurate with the present cost of living.' The government should buy cane directly from the growers and intervene actively to resolve the dispute. The growers would sacrifice some of their earnings, but were not prepared not to fill the coffers of the Company.

The government's response was predictable. The growers would have to sell the cane to the Company, not to the government itself. The CSR and not the government was the only organisation capable of processing cane, which it would then sell to the Ministry of Food at a price fixed by the Ministry. The CSR, the Governor said, was the 'agent of the Ministry for processing the cane and manufacturing and exporting sugar.' The implication of associating the interests of a private commercial enterprise with that of the government 
was that the growers were unpatriotic in their demand for a better price for their crop. Opposing the CSR was, in other words, tantamount to opposing the colonial government and the wider imperial interests.

The government's stance, which appeared to favour the Company, further antagonised Patel and other growers' leaders. On 7 September, Patel telegrammed the Governor rejecting the government's contention that the CSR was the agent of the Ministry of Food, for that would once and for all place the growers at the Company's mercy. Would the Ministry publicly announce that it would buy cane from the Fiji growers and appoint the CSR, its duly authorised agent, to take delivery of the cane from the growers? 'While other sections of the community including the Company are making larger profits on account of the war, there is no valid reason why the farmers of Fiji should make themselves the objects of charity when they can also make larger profits by resorting to the cultivation of some other crops which are at the same time more vital and essential to the war effort of the United Nations and especially to the life of the community.' The growers, in Patel's view, were justified in asking for a one hundred per cent rise in the price of cane, but he was prepared to compromise. He would advise the growers to accept an increase of five shillings per ton for the current year's crop if the government agreed to carry out an enquiry into the sugar industry and settle the basis of a future price.

To this suggestion the Governor replied the next day that since the growers were refusing to give evidence to the Commission of Enquiry he had set up, he had 'no means of knowing if an increase should be recommended to the Ministry of Food nor what such an increase should be.' It was a fair point, and Patel conceded it in his reply on 10 September. However, he said that his figure of five shillings per ton was 'not based on cost production but as a temporary expedient to settle the dispute quickly' He reminded the Governor that even with this figure, the growers stood to lose substantially. The government, Patel suggested, should take a larger view of the crisis. It should not cut its nose to spite its face. It would be far better to accede to his request and put $£ 175,000$ in the growers' hands and save a crop estimated at $£ 700,000$, instead of procrastinating further.

By mid-September, the battle was truly joined. The CSR, convinced that it could outlast the farmers in the long run, refused to reconsider its position, while the growers rejected the terms demanded by the Company. On 20 September, Patel wrote to the Governor to place their case before him, yet once again. He complained of the CSR's 'unreasonable and dictatorial attitude towards the growers.' The Company, he said, constantly reminded the growers that it was a commercial concern which existed to make profit for its shareholders. But it 'ignored the equally patent fact that the sole aim of the growers in producing sugar cane is also to make profit. Unless the growers obtain a reasonable margin 
of profit consistent with the work and capital they put in and the risk and patient waiting they take in the production of cane, there is no justification for them to continue cane farming.'

The CSR was being vindictive, Patel said. Its attitude showed that it would rather undergo loss at present and keep the growers in the position of serfs so that their exploitation may remain as easy in the future as it has been in the past.' The Company had withheld from the growers the price of bonus of the 1942 crop in order to 'starve the growers into selling their cane to the company at its dictated price.' It was making other threats as well. The Company was telling growers that unless they began harvesting immediately, it might not buy their crop at all. The growers demanded the immediate payment of the price bonus for the 1942 crop, resumption of negotiations with their representatives to settle the present and future price of cane, and a guarantee from the Company that it would buy the entire crop from them. For its part, the government should withdraw all impending prosecutions and orders for internment against those involved in the dispute. Otherwise, the growers would plough out their crop and use the land to grow other food crops.

By now the government's predictable response was to refer the question of the price of cane to the Commission of Enquiry. Furthermore, it threatened to prosecute anyone who might disrupt the sugar industry. The commission, by which the government had placed so much store, produced its report in November. It was an embarrassment for which the government was unprepared. The commission reported that the price of cane had kept pace with the cost of living. The debt problem among the growers was caused not by the low price of cane but by their own thriftlessness and extravagant social customs. The Governor cabled London not to accept the commission's recommendations.

Patel and other growers' leaders who had opposed the appointment of the commission all along felt vindicated. Patel, in fact, wrote a lengthy critique of the report and circulated it among the growers in western Viti Levu. The commission, Patel argued, had erred in using the 1939 price as the fair base price. Said Patel:

The legitimate and proper method of arriving at a fair price is not by ascertaining how little a cane farmer and his family can live on but how much the sugar industry at present can fairly afford to pay for sugar cane. This can only be ascertained by going into Company's accounts and ascertaining whether their profits are higher now than they were before the war. If they are, then the grower is not bound to make and ought not to be made to undergo any sacrifice, because his sacrifice only helps to augment the profits of the Company at the expense of himself, his family and his community. 
How was a fair price to be calculated? Patel offered this formula: 'The value of sugar plus value of molasses minus manufacturing cost, depreciation and a reasonable margin of profit divided by the number of tons of cane crushed equal to the price of sugar cane per ton.'

Equally unacceptable to Patel was the method the commission had used to calculate the cost of producing cane and the growers' cost of living. Patel's response is paraphrased at length. The learned commissioners, he said, had adopted an earlier official report on the cost of living of unskilled labourers in Suva. That report was based on the needs of an unskilled labourer and its premise was - 'thou shalt live on bread alone, and if there is a deficit, well, we know, you will make it somehow, by begging, borrowing or stealing.' There was no such labourer with a family, who did or could live on a standard prescribed by the report. The fact was that Indian cane growers had never lived in the past, did not live now and never proposed to live at such a meagre standard of life which, in his opinion, was no better than that of animals. The peasants were accustomed to a higher standard of life and even that standard was considerably below the standard which one could fairly call decent.

Instead of following the advice of the Secretary of State to the colonial governments to improve the standard of living of non-European races living in the colonies immediately, the commissioners were condemning the growers to a standard considerably below the one they were accustomed to. 'Does anyone know of an Indian cane farmer's wife who lives or who would actually be content to live on one skirt made of six yards of print or haircord, one blouse made from $1 \%$ yards of print or haircord, one slip of calico and a three yard muslin 'ornee,' a year, all at the cost of 11.12 .10 ? We believe that such a wife can only exist in the day-dreams of a poor husband harassed by the extravagance of the wife or in the report of a commission. The same thing applies to the clothing of the man as well as the children. In short the commission expects an Indian owning 12 acres cane farm, who has a wife and four children to support, to clothe himself and his family now on £13.16.1.' As far as the commission was concerned, Patel went on, the Indian farmers were no more than mere animals leading a life of isolation and not members of society with any social functions and obligations.

An average cane farmer was supposed to meet his social obligations, educate his children, marry sons and daughters, foot funeral expenses of relatives and meet a host of other expenses, within the sum of £5.7. a year! The expenses involved in entertainment and other recreations would, of course, be unthinkable in the eyes of the commissioners. What about paying interest on his debts and some saving for a rainy day? And what about comfortable and decent housing? The commission would be horrified even to hear that growers should entertain any idea of educating and marrying his children or meeting his social obligations or providing his family and himself with a few amenities of life. Indian growers 
were thrifty in comparison with their counterparts in other communities. Yet, in spite of that and an efficient standard of husbandry of a decent-sized holding of 12 acres, they had for years met the deficit by incurring debts, because the Company did not pay them a fair price for their cane. The lot of the cane grower, to be born in debt and to die in debt, might mean nothing to the Company, if that ensured and enhanced its profits, said Patel. But it meant a lot to the growers concerned and to the colony as a whole. It was a social evil which the government was morally obliged to end.

The conclusion of the report amounts to this. We will not recommend a rise in price and we advise an Indian average grower to live on the cheapest diet just enough to keep his body and soul together; he should never dream of meat, fish, or eggs even though the majority of growers are meat eaters; he should clothe himself and his family with the cheapest clothes sufficient not to make themselves liable to a prosecution for indecent exposure; we advise him not to think of the education or marriage of his children, and to avoid all social obligations and amenities of life; we have allowed £5.7.7i on top of food, fuel, housing and clothing of the most primitive type and a splendid margin of $£ 6.14 .9$ is left for him, that is of course if he does not pay $£ 20.0 .0$ to a cane cutter instead of £10.0.0 as we advise and some how limit the cost of cultivation within the straight jacket we have laid down in our report; but, if he has to pay £20.0.0, well, he can further tighten his belt and go in sack cloth and ashes, can't he?

On Christmas Eve 1943, the government enlisted Ratu Sukuna's support to restart negotiations with the growers' leaders. ${ }^{28}$ Sukuna travelled to Nadi and met A.D. Patel along with S.B. Patel and Swami Rudrananda at Patel's house. On 26 December an agreement was reached, and all four signed it. The actual agreement was as follows:

After considering the interest of growers, the sugar industry and the economic welfare of the Colony, we the undersigned agree that it is in the best interest of all parties concerned to settle the present dispute over the price of cane immediately in the manner following, that is to say:

1. The growers would offer their cane to the Government who will be responsible to the growers for the payment of a fair price.

2. The Government should appoint as early as possible [a] Price Fixing Board to determine [the] price of sugar cane from year to year.

28 For the negotiations, see CSO 2/19, part 3, and the strike file of Swami Rudrananda. It will therefore not be necessary to make lengthy references to sources about what follows. 
These are the broad principles on which the dispute can be settled. If these two principles are acceptable to His Excellency, the details of the settlement may be discussed with His Excellency by us and may be agreed upon.

Nadi, 26th December 1943 sgd. J.L.V. Sukuna Swami Rudrananda A.D. Patel S.B. Patel

Ratu Sukuna travelled back to Suva with the signed document and presented it to the Governor. At first the Governor seemed pleased at the imminent breakthrough. He cabled London approvingly, but then changed his mind after further discussing the draft agreement between Sukuna and the growers' leaders with the CSR. It was clear that the CSR would not, under any circumstance, accept the formula. The government was caught in a most embarrassing position. Sukuna had signed the agreement - his signature was proof of that; and much as the government regretted Sukuna's action, there was little that it could do about him. On the other hand, the government could not ignore the CSR's adamance either.

So, on 28 December, two days after the agreement had been signed, Sukuna wrote to Patel restating the government's old position. Since the CSR was the only organisation capable of processing cane in Fiji, Sukuna told Patel, 'any arrangement for delivery of cane to Government would therefore, in effect, have to mean delivery to the Company' As for their demand for an increase in the price of cane, 'there was no properly attested evidence adduced' that justified it. That being the case, the government could not give any guarantee of a fair price. That was a matter to be resolved between the CSR and the growers. Regarding the suggestion about a price fixing mechanism, the matter was before the Secretary of State for the Colonies. The ball was in the growers' court as far as the government was concerned, Sukuna said, and it was up to their leaders to prove their loyalty to the colony.

A.D. Patel, S.B. Patel and Swami Rudrananda replied to Sukuna's letter on the same day. They agreed that the matter of price-fixing legislation was before the Secretary of State, and there was little the Governor could do to hurry the matter along. But 'in order to reassure the growers and encourage them to plant cane,' the government should announce this publicly, as well as its intention to introduce such a legislation when London's decision became public. The Governor was not prepared to commit himself to any particular course of action. On the question of the delivery of the cane to the government, Patel stated: 'We realise that the delivery of cane to government would be in effect delivery at the Company's tramline as agreed amongst us during the discussion.' He also reminded Sukuna of the agreement (which he had signed) to leave the question of fixing a fair price 'to the conscience of the government.' The government 
would have none of this. The delivery of the cane meant its delivery to the CSR: 'there appears to be no point in maintaining the fiction that Government is to be a party to the transaction, except as a benevolent onlooker.' And the question of a proper price, it said, was not a matter 'of conscience but of contract.' That, in effect, meant that the growers would be paid according to the existing contract between themselves and the CSR.

Patel wrote to Sukuna again on 30 December, reminding him of the agreement he had signed, according to which the growers were to sell their cane to the government which would then be responsible for paying the money. The government would instruct the farmers to deliver the cane to the CSR tramline, which the growers would be obliged to obey. But the growers were clear on one thing: it was the government they were dealing with and not the CSR. In their view, therefore, the government was 'not a benevolent onlooker but the other party to the transaction.'

When the government refused to budge, Patel made a final offer through Ratu Sukuna on 3 January 1944. The growers, he said, would offer their crop as a gift to the government, and would even harvest it for them for a modest cutting fee. Patel told Sukuna: 'I am sure you will appreciate the difference between the growers' willingness to undergo sacrifices to assist the war effort and unwillingly under pressure selling their crop to a private profit making monopoly at the price dictated by it for the sole purpose of making as much profit for its shareholders as possible.' For his part, Sukuna disputed Patel's claims about the government's complicit role in the dispute, criticised him for prolonging the strike, defended the CSR for fulfilling its part of the bargain, and suggested that the growers should harvest the remainder of the crop and resume planting for the next season as a gesture of support for the colony's war effort.

By early January, it was clear that the fight was over. The combined power of the CSR and the government had overwhelmed the farmers' will to resist, many of whom were already heavily in debt. So they finally agreed to harvest what was left of their standing crop. At least as far as they were concerned, they were selling their crop to the government, and not to the Company. By then, some 14,000 tons of cane had been burnt and destroyed and some one thousand acres ploughed out. Of the estimated total of 824,801 tons of cane, only 434,168 were harvested $(332,669$ tons of green cane and 101,499 tons of burnt cane).

In 1944, the government asked Professor C.Y. Shepherd, of the Imperial College of Tropical Agriculture in Trinidad, to enquire into the sugar industry. The farmers repeated their by now standard complaints before the enquiry, and made some additional ones. The CSR should add the value of molasses and bagasse to the price of sugar when calculating the price of cane, allow farmers to choose from a variety of cane so that they could choose one more suited to the 
soil conditions of their farms, and permit farmers to grow food crops on a part of the land leased from the CSR. Patel also asked for a Sugar Board, comprising the representative of growers and the Company and the government, to oversee the industry. The Company, too, reiterated its position that it had not been making the huge profits its detractors were alleging.

The commission found that the cost of living of the growers had increased dramatically by 115 per cent between 1939 and 1945, while the average price of cane in the same time period had increased by only 50 per cent. ${ }^{29}$ It agreed that many farmers were indeed in debt. Nonetheless, the Commission thought that the CSR had not made substantial profits, though it could have afforded to pay more for the cane than it was prepared to. On an important point, Shepherd agreed with Patel. There was a need for an independent Sugar Board, with an independent chairman, to oversee the running of the sugar industry. Patel, who had accompanied Shepherd during his tours of the Western Division, impressed him with his intelligence and knowledge of the sugar industry. Indeed, in a private note to S. Caine of the Colonial Office, Shepherd said as much, and thought Patel would make an excellent member of the Board when it was established.

The CSR was pleased with the report which it found 'so favourable to the Company we are surprised that Professor Shepherd has considered it necessary to recommend any alteration at all.' Those changes he did recommend, as we shall see, the Company found ways to stifle and water down to such an extent as to make them irrelevant. Patel and his group gave the report a lukewarm support. They argued that the Company's assets were overvalued, and thus the depreciation which the Company obtained at the rate of 4 per cent per annum was excessive. Shepherd should have made more searching enquiries into the actual value of the Company's assets, rather than depend on their stated value. They rejected Shepherd's view that 'improvident farming' was largely responsible for the plight of the farmers. But the farmers accepted the recommendation to create a Sugar Board consisting of elected representatives of the growers, the government and the Company. Similarly, they welcomed the recommendation to create a Scientific Investigation Committee with representatives from the growers on it.

At first, the government reacted favourably to Shepherd's recommendations, but when the CSR objected, the government retreated. Thus, for instance, it accepted the Company suggestion for an advisory Cane Experiments Consultative Committee, instead of a Scientific Investigation Committee, with no power to direct experimental work which would continue to be carried out by the CSR at its own expense. Similarly, the government, at CSR's urging, 
procrastinated on the creation of a Sugar Board. In CSR's view, the Board would be 'regarded by growers' leaders as a stepping stone to the control of the industry or even nationalisation.' If the Board were established, the CSR said, both the government and the Company 'would find it difficult to resist the political pressures to grant more and more voice in the control of the industry to the Indian growers, or rather to their political leaders. ${ }^{30}$ It would take another strike and another commission of enquiry for the government to finally create such a board in the 1960s.

Several things become clear from the above account of the strike. Patel and other strike leaders were not playing fiddle while Rome burnt. Throughout, as we have seen, they struggled to find a solution to the crisis. The government, and his opponents, charged that Patel was quibbling over details and prolonging the crisis unnecessarily; but there was more to the story than that. Patel responded to the criticism: 'I am convinced that I was taking up a true and a just cause and I am convinced that the stand I took was the right one, that the advice I gave to the growers was right and I am proud of the part I played in that dispute.' He quoted Sir Philip Mitchell, the Governor of the colony during the dispute: 'Patel, you would never be able to convince me that I was in the wrong, and perhaps I would not be in a position to convince you that you were in the wrong, but I wish you to know that I respected you all along for the manner in which you opposed me.'31

In the ultimate analysis, the strike was not about personal egos and wounded pride and selfish ambitions of vain individuals, as the critics of the strike tried to argue; it was about re-structuring the sugar industry, replacing a serfbaron relationship, as Patel put it, with a relationship of equal partnership. He acknowledged the contribution the CSR had made to the colonial economy, 'but they have been amply paid for what they did for the people and government of Colony, not only amply paid but paid over and over again.' The CSR had to realise that the times had changed, and that farmers could no longer be bullied or coerced into submission. The CSR was a giant that did not need to be feared, Patel said, but faced, tamed not succumbed to. For that to happen, it was vital to have the government involved in the sugar industry. Patel went further and called for the nationalisation of the sugar industry to introduce some measure of control over the CSR and to ensure that 'the conditions of the workers and primary producers in that industry can be improved. ${ }^{32}$ The government could not be a neutral onlooker. The farmers suffered greatly from the strike; many were broken and went bankrupt; but they realised that one could not always have rain without thunder.

30 CSR's Fiji Inspector to General Manager, CSR Sydney, 23 October 1952.

31 Legislative Council Debate, December 1945.

32 Legislative Council Debate, December 1945. 
The strike was Patel's baptism of fire in Fiji politics. He had remained true to his convictions and refused to succumb to pressure from the Company and the government. For his stance, he won the respect of those who opposed him in public. Most importantly, Patel won the respect of the Indian cane growers, many of whom were intrigued to find a Gujarati lawyer fighting their case without fee, and who was prepared to go to jail for the principles he believed in. His resolve and fearlessness had stirred them and stiffened their own determination to stand up for their rights in ways that had seemed unthinkable in the prewar years. Even though the strike had failed, the ordinary farmers had gained something more. Through all the sacrifice and the suffering they had endured, they sent forth the message that they could no longer be taken for granted by the Company, that they would stand up for their rights and interests even at great cost to themselves. The Indian cane grower would no longer be 'timid and totally ignorant of what takes place outside his own domestic circle,' as Secretary of Indian Affairs McGusty had told CSR General Manager Sir Philip Goldfinch in February 1940. ${ }^{33}$ Patel had fostered a powerful, determined resolve among his people, and they elected him to the Legislative Council in 1944. 



\section{Chapter 5: Flesh on the Skeleton}

Until the people of the Colony realise their duty towards the working classes of the Colony, until we fix a minimum wage for the working classes in the Colony, we must provide relief to these people, not as act of charity but as a matter of obligation.

\section{A.D. Patel 1945}

The Indian has not the slightest desire or motive to dominate any community in Fiji. We have got to find a solution whereby none of the three important communities residing in Fiji may have any reason to feel that any one of them is being dominated by another other.

\section{A.D. Patel 1947}

The smoke from the fires in the cane fields had barely cleared the mountain ranges of Western Viti Levu when elections for the Legislative Council were held. A.D. Patel was elected to the Council from the North Western Indian constituency, winning 1841 votes to 554 for the incumbent and his opponent in the strike, B.D. Lakshman. ${ }^{1}$ The main reason for Patel's victory was his role in the 1943 sugar cane strike. The government and opponents of the strike had hoped that because of the hardships they had suffered, the Indian cane growers would reject Patel. The growers, however, thought otherwise. Patel would remain an elected member of the Council for the next six years, defeating his old rival Chattur Singh by 1972 votes to 1106 in the 1947 election. The post-war years were a time of unprecedented flux in the colony as it struggled to accommodate the social, economic and political issues and challenges that followed the war. We will look at Patel's thoughts on some of them, but first it is necessary briefly to look at another event which cast a dark shadow over the subsequent history of Fiji: the Second World War.

Fiji, like all the other members of the British Empire, went to war on 4 September 1939. The Governor announced the news at 8 o'clock that night by radio. The freedom of the whole world would be in danger if the principle of might is right were allowed to go unchallenged, he said. 'But far more than this, the peoples of the world would be kept in bondage of fear; and all hope of settled peace and security of justice and liberty among nations, would be ended. This is the ultimate issue that confronts us.' ${ }^{2}$ A curfew was declared, censorship on postal and telegraphic communication imposed and the movement of enemy

1 Patel did not contest the 1940 election because he was in India attending a conference of the Indian National Congress as a representative of the Fiji Indian community.

2 CSO F115/11. 
aliens monitored. Measures were taken to increase the revenue of the colony to meet the extra cost of supporting the imperial war effort. Individual and residential taxes were increased by 25 per cent and corporate taxes by 50 per cent. Eventually, Fiji's total war expenditure would amount to nearly $£ 5$ million, the largest of any comparable colony in the Empire, and nearly half of the total revenue raised in Fiji during the war years. Individuals contributed generously. The Indian community raised enough money on their own to buy a fighter bomber for the Royal Air Force, which they asked to be named the Fiji Indian.

At first the news of the outbreak of the war caused much anxiety in Fiji, but with time, life returned to normal. It was difficult to remain constantly on edge about an event taking place on the other side of the world. But when Japan entered the war in 1941, the situation changed, even more so as it advanced menacingly southwards into the Pacific. To enlist the support of the Indian community, the government appointed a broadly representative Central Indian War Committee whose members included, besides A.D. Patel, Vishnu Deo, A.R. Sahu Khan, B. Raghvanand, Tulsi Ram Sharma, Andrew Inder Narayan Deoki, K.B. Singh, B.D. Lakshman, Dr C.M. Gopalan, Dr Girin Mukherji, H. Sahodar Singh, and Ramakrishnan. On 11 May, the Committee met to consider various proposals put forward by the government regarding the war effort. ${ }^{3}$ A number of resolutions were adopted. The Committee noted the change in the government's invitation to the representatives of the Indian community to discuss ways of furthering the war effort, but sought 'further assurance that the policy of political and economic discrimination against non-European races in the Colony would be abandoned.'

Petty racial discrimination rankled with the Indian community. There was residential segregation in all the major municipalities. Indians could not use the Suva Sea Baths even though they paid their city rates. The best wards in hospitals were reserved for Europeans. No non-European could hold any position in the civil service beyond the level of grade two. Europeans were entitled to trial by jury in all cases at law, but non-Europeans were not. Non-European children were excluded from European schools, such as the Suva Grammar. There were other petty restrictions, including the liquor restriction which required Fijians and Indo-Fijians of 'good standing' to apply for a permit to drink. If the war was being fought to secure peace and justice and freedom, as the Governor had said it was, then these values should be reflected in the public life of the colony, Indian leaders demanded. The government had indicated that it might enlist Indian troops for the Fighting Battalion, Pioneer Battalion, Reserve Pioneer Battalion and other units including the Medical Corps. The Committee raised no objection but requested recruitment on a voluntary basis. This was important, because the Indian farmers were living in settlements and depended on their own, as

3 Fiji Times, 12 May 1942. 
opposed to communal, labour to work their land. The Committee insisted that non-European soldiers, including the Indian recruits, receive the $3 \mathrm{~s} .0 \mathrm{~d}$ per day and the separation allowance of 3s.0d and ls.6d per child that Europeans were receiving: equal pay, equal worth, equal risk. And finally, the Committee agreed for the Indian community to participate, at government direction, in any 'other measures of relief vital to the safety of the civilian population of the Colony.' For the Indian leaders, the principle of equality was important. As they told the Governor, 'It is a question of terms and conditions, not the intrinsic value of money. It is the value generally placed on Indian labour and Indian service.' It was, for them, the question of the 'value of the life of an Indian joining the Labour Battalion.' Said Hasan, the Muslim leader, said he did not favour discrimination and that he appreciated the 'reality of the situation' but he asked the government to pay at least a living wage to those who bore the brunt of increased cost of living on account of the war.

The Indian community's response appeared lukewarm, conditional, while the Fijian community was exuberant in its support of the war effort. Culture, history, the nature and focus of the recruiting drive, and official attitudes and preconceptions, all accounted for the difference in the attitude of the two communities toward the war effort. ${ }^{4}$ There were many reasons for this disparity. The Indian Central War Committee gave some of them, but there were others. One was the government's reluctance to enlist Indians as soldiers, official pronouncements notwithstanding. In 1916, the government had rejected Manilal's offer to send an Indian platoon 'to take part in the responsibilities of the Empire at such a critical time as the present. ${ }^{5}$ It reluctantly created an Indian Platoon in 1934, but disbanded it in 1940, just when it was asking the Indians to enlist. When the issue was raised, the Governor added that the 'disbandment was not due in any sense to [the] unwillingness on the part of the Indians to serve in the armed forces of the colony. ${ }^{6}$

Soon after the outbreak of the war, the South Indian community approached the government through A.D. Patel and offered a volunteer corps to do first aid work and requested training and equipment for that purpose. The government did nothing. Chattur Singh approached the Governor and offered to enlist his own two sons in the army and navy. Sir Philip Mitchell, the Governor replied: 'I am the Commander-in-Chief, but I cannot rule the army. ${ }^{7}$ In 1942, 40 Indo-Fijians

\footnotetext{
4 See Ravuvu, Fijians At War, 1974. The following account of the Indian response draws heavily on Lal, $1992,122-124$.

5 CSO $5113 / 16$

6 Fiji Times, 2 May 1942.

7 Personal communication with the late Chattur Singh. I have his letter on the subject. A.R. Sahu Khan's account of difficulties is in the Legislative Council Debates of 20 December 1965.
} 
in Ba offered to enlist, but the European officials turned them down for various reasons. Similarly, when 50 Muslims volunteered for service, without any conditions, refusing to make equal compensation an issue, nothing happened.

One reason was the European opposition to giving the Indians any military training at all. The Indian community's loyalty to the Colony was suspect, not necessarily because of anything it had done but because of events in India, such as the gathering pace of the nationalist movement there, which the Fijians and particularly Europeans did not understand but which they nevertheless detested intensely. Giving Indians military training could conceivably sow the seeds of problems further down the road. On top of all this, the officials thought that Indians would not make good soldiers anyway, unable to submit 'themselves to the control, restrictions and rigours of life in a strictly disciplined force, to accept without complaint the restrictions of individual rights and convenience inevitable in a disciplined communal life, to accept and obey unquestioningly, the orders of superior officers and especially to have the capacity rapidly to assimilate to complicated training which is the lot of modern soldiers. ${ }^{\prime}$ The colonial officials conveniently forgot that the Sikhs were regarded as being among the best soldiers in the world, having served with distinction in the British Indian Army since the middle of the 19th century. Given such an attitude, it was no wonder that the government's recruitment drive among the Indians lacked focus and energy.

The truth was that the government did not want Indians as soldiers but as producers of foodstuff. Fiji was an agricultural colony, the Governor said, 'composed of islands which in the nature of things do not produce munitions of war and whose peasant farmers in these circumstances could probably best help the war effort by pursuing their own vocations.' 'I assure you,' he told the Indian Central War Committee, 'and I ask you to carry that assurance back to your Districts when you return - that the efforts of the Indians in Fiji in response to Government appeals for the growing of foodstuffs and the maintenance of essential agricultural interests have been not one of the least important contributions made to the prosecution of the war effort. ${ }^{9}$ The CSR shared that view. Its manager at the Lautoka mill, E.H. Griffith, wrote to District Commissioner J. Judd that recruitment of Indians was hurting the sugar industry and should be discontinued. The District Officer Nadroga was accordingly instructed by Judd that on 'no account are tenants [of the CSR] to be permitted to leave their farms to join the Labour Battalion. ${ }^{10}$ The Company's

8 Governor's address to the Legislative Council on 23 November 1957 on why he was unable to authorise the enlistment of Indo-Fijians for Malaya. The logic was the same in 1943.

9 Fiji Times, 2 May 1942.

10 CSOF8/69. 
tenants were bound by an agreement not to be absent from their farms for more than two months a year; so the choice between enlisting for war on the one hand and keeping their farms on the other was no choice at all.

It was often said that the Indian leaders were actively disloyal. A.D. Patel was accused by an Indian agent in government service of being 'hopeful that the Japanese would invade the island' because he, Patel, was 'dreaming of a Japanese wife. ${ }^{11}$ This was an amusing invention of a hyper-active mind of a government informer. To be sure, not everyone in the Indian community thought that the membership of the British Empire was a badge of honour. Many were still tied by emotional and cultural ties to India, and followed the news of developments there. That was only to be expected in a colony characterised by communal compartmentalisation which had obstructed the development of a common citizenship. But there was no question of not defending Fiji if it were attacked. As it happened, not a single shot was fired in the defence of the colony. Nonetheless, it is true that Fiji Indians were on the whole reluctant to become cannon fodder in the defence of a 'white race empire.' Poverty, indebtedness, disease, and discrimination were for many ordinary people far greater evils to be fought and eradicated first before shedding blood on alien lands to defend colonialism and imperialism. The Indian community was never disloyal to the colony. Only exuberant Fijian war effort and European propaganda made them appear so.

Patel articulated the interests and aspirations of the Indian community in the Legislative Council which he entered in 1944 and where he remained until 1950. His tenure there coincided with profound changes in Fiji in the immediate aftermath of the war. Some changes were planned by the government as part of its 'post-war reconstruction' policy, to guide Fiji to a new order without losing control of the direction or nature of the changes. These included reforms in social legislation, immigration, the structure and power of local government, native lands policy, education, health and the constitution. Patel's contribution to the debates on these issues demonstrates a trenchant critique of government policy, and provides tantalising glimpses into an alternative vision for Fiji. Among the changes Patel advocated in the 1940s included rapid localisation of the public service, protection of the right of workers to organise, social security and the acceptance of the principle of equal pay for equal work, irrespective of gender, creed or race.

At the core of Patel's vision was the call for an open, equitable and non-racial society. The passion with which he advocated this vision was often rejected with equal passion by Fijian and European members and ultimately by the government itself. There were also issues on which Patel differed from his

11 CSOCF2/19/1. 
own Indian colleagues, such as Pandit Vishnu Deo. These differences had deep cultural and ideological roots in the Indian community, and they eventually helped to cause Patel's electoral defeats.

In 1944, as the war receded from the South Pacific, the colonial government, with the guidance of Whitehall, began planning for a new order in Fiji. It produced blueprints to build or improve the infrastructure of the colonybuilding bridges, tarsealing roads, improving water supply in urban areas, extending electricity, planning better hospitals. Peoples' horizons had been widened, and the government was keenly aware of the need to act quickly. All these planned changes were 'beautiful and useful things in themselves,' Patel said, 'as important to this new social order as the skeleton is to the human body.' The provision of new facilities and the expansion of the infrastructure were important, but not enough by themselves. What was needed, Patel said, was a broad vision of social security to the poorest sections of society to 'ensure to human beings freedom from want and freedom from fear.' What was required was to fulfil Whitehall's promise to raise the standard of living 'of those whose incomes were not adequate to ensure them a decent standard of living.' The colony had been assured that the labour penal laws, which were 'a disgrace', would be repealed, and the trade union movement and the working classes would regain the right of collective bargaining. 'When will the dawn come that heralds this new era which is supposed to be based on equity and social justice?' asked Patel in December 1944. ${ }^{12}$

The government pointed to the newly-created Department of Labour which was specifically instructed to look into matters relating to workers' complaints. But, argued Patel, the Commissioner of Labour, Stuart Reay, was a second grade official, whose office consisted of just himself and a typist. The employers and the labourers alike saw him as a District Commissioner elevated to the rank of a Commissioner of Labour, with the result that neither side had confidence in him. When Patel criticised the ineffectiveness of the labour department, he was speaking from experience. He had been a member of the National Service Tribunal and seen at first hand how, untutored in industrial dispute resolving procedures, the workers were unable to present their case effectively in arbitrations. He gave an example. Two official inquiries had found that even with the most elementary standard of living on the most meagre budget, the workers were unable to make ends meet. When they struck for better wages, the government asked them to go before the tribunal. But the workers hesitated, not understanding the complications of law and the legal machinery. To begin with, they had to make a case before the tribunal could consider it under the National Service Regulations. Hampered by ignorance of legal procedures, the workers could not distinguish between agitating for a living wage and asking for a wage

12 Legislative Council Debate. 
increase due to the increased cost of living during wartime. As the two issues were confused, they ended up with an award that linked their bonus to the cost of living index, with the result that, as Patel put it, 'the present income of a labourer is still less than it was before the war to meet his needs.'

There were some in official circles, not to mention among employers, who thought that the workers 'were very inefficient and slack in their work'. For his part, the Commissioner of Labour accused Patel and others like him of appeasing the labourers. Patel disagreed. The workers, he said, 'had shown an admirable amount of patience and understanding,' but their goodwill could not, and should not, be taken for granted. They were among the poorest sections of the community, furnishing the largest number of destitutes. He pleaded for a minimum wage legislation for the workers. 'Until the people of this colony realise their duty towards the working classes of the colony, until we fix such a minimum wage for the working classes of this colony, we must provide relief to these people not as an act of charity but as a matter of obligation.' The cane crushing season was about to start, Patel warned, and the labourers would naturally be asking questions about their work, wages, conditions of employment and other such matters. Unless the government acted quickly, it might have a major industrial dispute on its hands.

There was something else to consider. Labour relations, Patel said, was not an issue that could be left to the employers and the employees alone. 'Of course we have made promises that the trade union movement will receive every encouragement at the hands of the government but we must also consider the illiteracy and the ignorance of these unskilled labourers.' The workers, Patel said, would need 'some time and some training and some education before they will be in a position effectively to organise themselves and be in a position collectively to enforce a fair and just bargain from their employers.' Until then, he said, the government should treat the workers as their wards, and not act as 'sheep dogs of the employers of the Colony.' The government listened, but refused to act.

In December 1945, the government moved to amend the Residential and War Tax Bill. In doing so, it wanted to remove the war time label, and increase the amount from $£ 1$ and ten shillings to $£ 2$ annually. The tax was to be paid by 20,000 non-Fijians who 'are not touched to any great extent by other forms of direct or indirect taxation,' exceptions being people with more than five children (or with other dependents), prisoners, students and others suffering from some disability. The government justified the tax on a number of grounds. First, the amount was not excessive and it did not represent a substantial increase on the existing amount, an increase from merely 2 shillings and 6 pence a month to 3 shillings and 4 pence a month. Second, if people wanted improvements in health, schools, settlement schemes and other social services, they had to 
contribute. And third, it was not fair to increase direct taxation while retaining the residential tax. The government thus justified the increase on the grounds of fairness and equity.

Patel led the opposition to the Bill. The government's argument about removing the war label on the bill was misleading, he said. There was no question of removing the war label as the War Taxation Ordinance of 1940, levied specifically for the duration of the war, for a definite purpose and a definite period, was to end in December 1946 anyway. The government was simply using the removal of the war label as an excuse to increase the residential tax from $£ 1$ to $£ 2$. To the argument that the increase was not substantial, Patel replied: 'As a member of the Labour Services Tribunal I had an experience where the representatives of the employers were fighting over not a half-penny but a fraction of a halfpenny a day, in the calculation of wages, but now when it comes to the labourer an amount slightly more than a penny a day is considered to be merely an insignificant thing that does not bring any hardship on them. A penny deducted from a daily wage of 4 shillings may not be felt, but every penny counted when it came to saving. Then the deduction becomes 'something which amounts to an ordeal for a poor man who has to live from hand to mouth every week and make both ends meet.'

To the view that everyone should bear the burden of taxation and pay for the benefits they derived from the provision and improvement of social services, Patel reminded the government that it was well established principle in all civilised countries of the world that no direct tax should be imposed upon the people irrespective of their means to pay.' There were poor people in England also, Patel argued, who did not pay direct taxation, and yet England had no residential, hut or poll tax. The principle of equity and justice had to be observed, too. Why should a single person earning, say, £650 a year pay the same amount of (residential) tax as a man with an annual earning of £72? Was there any justification why a man, with a wife and four children on an income of $£ 72$ a year, should pay $£ 2$ in residential tax while a spinster earning $£ 150$ was exempt from it?

The government had justified the increase in residential tax on two other grounds. One was the subsidy it had provided for flour and sharp to the tune of $£ 60,000$, suggesting that the benefit from the subsidy was far greater than the amount to be paid in additional tax. That was a 'thoughtless generalisation,' Patel responded, because that subsidy benefited all those who consumed products from flour and sharp, including the wealthy. A person benefited from the subsidy not 'according to his means but according to his consumption of flour and sharp.' There were sections of the Indian community which benefited less than others because their staple diet was rice, not flour. So the rhetoric about helping the poor was just that, rhetoric, because if it was to help the poor 
than the subsidy would have been limited to the poor only. The truth about the subsidy, Patel argued, was 'that the capitalist wanted to see that the cost of living in this colony did not soar up and form a vicious cycle whereby there would be a spiral rise in the cost of living all the time, a spiral rise of wages and a spiral and vicious cycle of rises in the prices of local agricultural produce, thereby upsetting their industries and their economic set up.'

The other justification the government had used in increasing the residential tax was that since it was increasing the direct tax on the Fijians, it was only fair that it increase tax on the non-Fijians as well. But two wrongs cannot make a right, Patel argued. There was a case for abolishing direct taxation on the Fijians, not a case for increasing the tax burden on the non-Fijians. In addition, there was a significant difference between the residential tax levied on the non-Fijians and the direct tax collected from the Fijians. The revenue from the tax on the Fijians did not come into the general revenue. Their direct taxation, he said, was entirely in the nature of their own local rates, spent entirely on facilities for exclusive Fijian use and benefit. The extent of Fijian contribution to the general revenue was marginal, from which the non-Fijians benefited little. Yet, the tax paid by the non-Fijians benefited everyone in the colony, including the Fijian people. 'The roads that we build not only improve their lands and bring them a higher rent but they also raise the value of those lands and make their lives in the villages and their social amenities so much better than they would otherwise be.' So the 'Fijian argument' made little sense. To Patel, the residential tax policy was unjust, iniquitous and unfair. H.B. Gibson called it this dirty little brother-in-law of the Taxation Increases family.' Along with four other European members of the Legislative Council (the exception being Hugh Ragg) Patel and his fellow Indian members voted against the Bill while all the official members and all the Fijian members voted for it.

In 1947, influenced by demographic trends, which saw the Indian population overtaking the Fijian, the government moved to restrict immigration into the colony. Previously, immigration matters were handled by the Commissioner of Police who was chiefly concerned with keeping undesirables out along with others who might become a burden on the colony's finances. Now, the Attorney General said, the government was 'concerned with controlling large-scale immigration, that is, the numbers of persons - be they good, bad or indifferent, of any walk of life, of any race or nationality - who may wish to reside in the Colony.' To that end, the Governor-in-Council was given the ultimate control over immigration matters, with the authority to decide the number of migrants to be allowed into the colony as well as restricting the intake by professional occupation or other such criteria to protect the interests of the local residents.

On the face of it, the proposed legislation appeared fair and equitable, but Patel exposed its hidden discriminatory aspects. On the question of future 
immigration into the colony, there was no difference of opinion among the various communities, he said. Any immigration policy for Fiji had to strike a happy balance between the interests of the colony, its social and economic needs and requirements, and its obligations and responsibilities in the international arena. He questioned the wisdom of 'giving a blank cheque to the Governorin-Council in full faith and trust that such a happy balance will be struck and the interest of the Colony as an integral part of this world will be preserved.' That responsibility, he suggested, should properly be vested in the elected representatives of the people.

There were other objections. A resident was defined in the law as a British subject or a British protected person, classified into three sections: those who were born in Fiji, those who were domiciled in Fiji and those, neither of the above, who had lived in Fiji for over five years. But there was no precise definition of what was meant by domicile, its interpretation left to the discretion of an immigration officer 'who will not be bound by any rules of evidence or procedure, and whose decision can only be arbitrary, dependent more or less on what proof he considers sufficient and what he does not.' What would happen if upon reentering the colony the immigration officer refused to recognise the person's claim to be a domiciled person? He could appeal to the Governor-in-Council, but not beyond him.

That, for Patel, was insufficient. 'The right of domicile is one of the most valuable rights of civilised human beings, and the highest tribunal of the Empire [the Privy Council] must be open for him to enforce that invaluable right if he cannot obtain justice in any other quarter.' Appeals to the Privy Council were allowed on much smaller matters, 'but when it comes to the right of citizenship, this Bill leaves it at the mercy of the executive discrimination of the immigration officer and Governor-in-Council.' He then went on to elucidate the real nature of this body. The Governor-in-Council 'is not a judicial tribunal for people to come openly before and enforce their rights and obtain judgements. It is a body that sits in closest secrecy. All its deliberations come under the Official Secrets Act. The person aggrieved has no access to it. He can only send his grievance in writing. He does not know what factors were taken into consideration by this body before it gave its opinion as to whether the immigration officer was right or wrong. There is no question of the aggrieved person cross-examining the immigration officer or pleading before the Governor-in-Council to substantiate his right; and if the Governor-in-Council decides against him, that decision is final and he has no further remedy left to him.'

There was another aspect of the proposed legislation to which Patel objected. A person who was neither domiciled nor born in the colony but who had lived there for five years had only 12 months in which to re-enter the colony without a permit. A longer period of absence would require a permit. The 12 month 
period posed few difficulties for people from places such as Australia and New Zealand because they were nearer, the passage was cheaper and shipping and air services regular. Not so, however, for those who came from the Indian subcontinent. They were disadvantaged by distance, irregular shipping and greater travelling expenses. And because they visited their homeland at long intervals, they might prefer to spend more time with their relatives before returning. 'The man who was going to India at intervals of five or six years had to work and live in this Colony for anything between 10 and 20 years before he could afford to take himself and his family back to India, and naturally at such long intervals he would want to spend at least two or three years before he returned because he is never sure when he will get another trip.' Patel suggested that the time be increased from one to three years. Extending the time limit would not adversely affect the interests of residents from the neighbouring dominions, while it would safeguard the interests of those from the Indian subcontinent 'who have played and are still playing an important part in the development and the maintenance of this Colony's economy.'

Patel's plea for openness and flexibility fell on indifferent ground. Although the Indian members supported him, they did not do so with any enthusiasm, for the Fiji-born business class did not particularly welcome the Gujarati and Punjabi competitors. Nor did the Europeans. Maurice Scott raised the issue of protecting the interests of the Fiji-born first. 'Fiji-born, Fiji-bred, Big in the Feet and Thick in the Head.' A Fiji-born Indian was a hardworking, law abiding person who had the Colony's real interests at heart, he said. It was the India-born who was poisoning his mind, disturbing 'the tranquillity of these islands.' These 'birds of passage' were unwelcome, and if he had his way, Scott hinted, he might ban them altogether. Behind Scott's altruistic-sounding, patriotic rhetoric was economic self-interest: the Gujarati and Punjabi businessmen were their biggest competitors.

Ratu George Tuisawau agreed, saying that 'if we do not shut the door to new comers now, all of us will regret it later on when there will be no solution.' The Indians were trying to control Fiji, making a bid for supremacy, Ratu George said. Getting carried away, craving the indulgence of the Council, he wanted 'to say what I want to say without pulling any punches.' Unless the Europeans and the Fijians were careful, they will be swamped, he said. He gave a warning: 'To the Europeans I say this: you are our superiors intellectually, numerically we are yours. Therefore, to afford our future salvation, you should give us your unstinted assistance. We are in the same boat and for sentimental reasons, we do not want to disassociate ourselves from you: united we stand, divided we fall.' That a motion to extend by a further two years the stay of Fiji residents abroad 
without jeopardising their right of automatic entry into the Colony could be turned into an issue of such doom and gloom is a stark reminder of the realities of communal politics in colonial Fiji.

There were other issues, some of even greater importance, which met a similar reception. Localisation was one. Patel urged the government to accelerate the recruitment of local people into the civil service. This was what international conventions, to which the colony was a signatory, were advocating. It was consistent, too, with the Colonial Office's policy to prepare colonies for eventual self-government. 'We have been told time and again that the aim and object of British colonial policy is to make every colonial territory fit for self-government, and no territory can be made fit for self-government until that territory can become self-sufficient as far as the personnel of the Administration is concerned.' ${ }^{13}$ Some departments of government could be localised immediately, Patel said, the Education Department being one prime candidate. The colony already had enough experienced primary school teachers who could become inspectors of schools, for instance. Indian schools were self-sufficient in teachers; it was only the Europeans who were importing teachers from outside, which was rather surprising, Patel said, in view of the European community's privileged economic and educational status in the colony. Expense was a consideration in favour of localisation, Patel argued, but there were others, such as stability and continuity in the system. He said: 'So far, education in this Colony has remained in the hands of people from outside: by the time they get a correct picture and first hand experience of the problems that they will have to solve in Fiji, they are already due for their first leave overseas. When they return back they might have a few ideas to put into practice or some new policy to introduce into the Department. While that is being started or their mind [is] being made up, they are transferred to another country and the education of the people remains where it was before. That has been the position and that has been the cause of our tragic delay all these years.' Patel also pointed to the Medical and the Lands departments where localisation could begin immediately. The important point was, he said, that a start had to be made so that when the time came for selfgovernment and eventually, independence, Fiji would have trained personnel to assume the reins of the country's administration.

But Ratu Sukuna objected, saying that localisation would in effect mean Indianisation. In any case, he preferred the English to continue ruling because their approach was based on 'the humanities, refined by Christianity, steeled by economic and political encounters, tempered by defeats and victories.' The English approach for Sukuna was 'the only effective approach to life.' ${ }^{14}$ Patel was advocating the recruitment and training not only of Indians but members

13 Legislative Council Debate, December 1945.

14 Legislative Council Debate, November 1947. 
of every community. And if the Fijian people were not yet ready for senior posts in government administration, that was all the more reason to accelerate their training. As Patel used to say, the Fijian community would progress only when it produced not only great chiefs like Sukuna, but also great commoners. But the government resisted. With such a powerful person as Ratu Sukuna on its side, the government could easily afford to ignore Patel.

Many of Patel's other proposals went unheeded, among them the introduction of a system of social security requiring an employer to 'contribute his share to such a fund so that in any contingency of being either permanently or temporarily disabled or in the case of old age, [the worker] will be provided for.' In 1945, Patel moved a motion to introduce Destitute Allowance and Minimum Living Wage legislation for Fiji. ${ }^{15}$ Social security would become a reality two decades later. He advocated open, common roll election for the municipal councils, and the abolition of the system of nominated councils altogether to pave the way for an equitable and proportional system of representation for all ethnic groups. ${ }^{16}$ Patel questioned the logic of reserving Native lands. Here was the government asking people to plant more food crops to reduce imports, but on the other hand the same government was sanctioning the reserving of productive land. 'We call a man who steals com from land a thief and punish him but when people steal land from corn, we call it Native Reserve.' 'Spare a thought for the dispossessed tenants,' he pleaded. 'They should be paid compensation for the improvements that the landlords took over. The public was not right in not helping the farmer when he is dispossessed and when we expect him to live somewhere else and go on developing the virgin lands of the Colony. ${ }^{17}$ He urged the Fijian chiefs to adopt a more progressive attitude to the changes taking place in Fiji (and Fijian) society, and to prepare their people for future developments on the horizon.

One issue that was bound to come up in the post-war debates on the colony's future was the constitution. The constitution of the Legislative Council had been framed by the Letters Patent of 1937 which provided for a Legislative Council of 15 unofficial members (three elected and two nominated members each from the European and Indian communities, and five nominated Fijian members), 18 official members, and an Executive Council consisting of the Governor and his official advisers. Under this system, the official members had a permanent majority so that any policy the government proposed was assured of a successful passage through the Legislative Council. The Governor, of course, retained the veto power over everything, which he exercised with the consent and authorisation of the Secretary of State for the Colonies. Aime Ragg called

15 Legislative Council Debate, 30 August 1945.

16 Legislative Council Debate, 20 November 1947.

17 Legislative Council Debate, 25 Novovember 1948. 
this a 'submerged autocracy,' and Patel labelled it 'impotent legislature,' for, in the ultimate analysis, no matter what their opinion, the unofficial members could not initiate any policy unless it was supported by the government.

To change that situation, Harold Gibson moved a motion in the Legislative Council in December 1945 to amend the constitution to increase the number of elected representation of the people so that a significant measure of control be exercised over the raising and spending of those comparatively huge sums of money which the people of this Colony will be called upon to provide.'18 Unless the membership of the Council was widened and peoples' elected representatives were given real power to make decisions on important issues, Gibson warned, discontent in the community would increase, with unforeseen consequences. He proposed to increase that the membership of the Legislative Council to 28 , made up of 18 elected representative (six from each of the three principal communities), seven nominated members and three ex-officio members (Attorney General, Financial Secretary and the Colonial Secretary) with the Governor as the President.

Aime Ragg agreed, saying that 'it makes one almost sick when one reads in the papers and hears over the air how we are going to have freedom from this and freedom from that and yet when it comes to a showdown those fundamental principles of freedom which are supposed to inhere in our constitution are denied to us.' The view that the Fijian people were not ready for change, which was often invoked to block any constitutional change, was simply untrue. For Ragg it was almost impossible to imagine ordinary Fijians not wanting the right to vote. 'To say that Joeli cannot choose between Sakiusa and Toganivalu or anyone else is just nonsense.' Equally nonsensical for him was the idea that 'if we give this system of representation to the Indians it will be a first step to a common roll/ and eventually Indian domination. The Indian people were not 'so bereft of commonsense as to think they can play in this Colony the role of running the Colony' The talk of Indian domination was a 'red herring.' But if the Indian people did make such a bid, the Imperial Government was still 'there to control us.' Ragg was no friend of the Indians; he devised plans and pleaded with the Colonial Office in London to have Indians deported from Fiji; but at least on this occasion, he spoke the truth.

Patel agreed that the Legislative Council was indeed an impotent body. For him, the whole set up was 'artificial and hollow.' Official members attended the Legislative debates, listened to 'boring and uninteresting dissertations from the unofficial side, knowing full well that the unofficial side cannot influence their minds in any way because they have no minds of their own to be influenced.' They voted the way the government directed them to. It would be more

18 Legislative Council Debate, 21 December 1945. 
productive, he said sarcastically, if the official members, who were all heads of departments, 'remained in their offices and attended to their duties.' There was only one mind in the Council and that was the Governor's. Everything else was a charade.

Even on the unofficial side, the situation was equally hollow, Patel continued, for how many people did the six elected members of the Legislative Council-three Indians and three Europeans - actually represent? The three Indian members were elected by a total roll of just 5,000, when the total population of the Indian community was around 100,000. A similarly disproportionate situation applied to the European electorate (counting the part-Europeans on the roll). And the commoner Fijians had no direct say whatsoever in the selection of their representatives to the Council. In short, the composition of the Council left much to be desired. 'If we are to have a genuine council,' Patel said, 'where the public opinion can be genuinely and properly reflected, the first condition is the widening of the franchise. Every adult member of the population, whatever race he belongs to, must have a vote; it must be a question of universal franchise.'

To those who thought the Fijian people were not ready for universal franchise, Patel replied that they perhaps had the pre-war Fijian populace in mind, isolated and out of touch with the outside world, though he himself was convinced that the common Fijian knew his own mind just as well as others knew theirs. The war had enlarged the horizon of the Fijian people who had come into contact with soldiers and social influences from the outside. The Fijian had 'certain democratic ideas, political viewpoints, ambitions and aspirations as regards his political rights, and we cannot pour that wine into old bottles: we must make sufficient provision for them.' The matter should not be left in the hands of the government or the Department of Fijian Affairs alone, Patel argued. He suggested a referendum among Fijians to gauge their political aspirations. But the Great Council of Chiefs opposed any extension of the vote to their people; the Council was itself in the process of reverting to its old chiefly-dominated social and political order through the newly-passed Fijian Affairs Act. It was not until 1963 that the Fijian people were finally given the right of universal franchise. It was not simply a question of extending the franchise, Patel argued further; the nature of that franchise was an equally important issue. For Patel, common franchise, the principle of one person, one vote, one value, was the only way forward for Fiji. 'I would not mind being represented in this Council by my honourable colleague Mr Aime Ragg, although I am an Indian. It is a question of mutual trust and confidence.' Common franchise had another advantage: 'a common denominator of political outlook will be developed in this Colony. As it is we are all thinking in narrow terms, of our racial interests, but if we take that bold step forward, we would all be thinking in general terms, the interests of the people of this Colony. Would not that be an ideal worth striving for?' 
For many, the common roll was like a red flag to an angry bull. Two fears were particularly strong among those who opposed the idea. One was that the Indian leaders would do everything to have common roll imposed on the colony, over the objection of other communities. And the second was that common roll would eventually lead to Indian domination of the political affairs of the colony. Common roll would not be thrust on any community, Patel assured the representatives of the other groups. 'I personally believe that if we are all going to be common voters and common workers in this Council it will only be through voluntary consent. There is no question of dominating or forcing one's views on another.' And Indian domination was out of the question because each of the three groups would have guaranteed equal representation in the Legislative Council. The only difference under a common franchise would be that racial rolls would be abolished and replaced by a multiracial electorate. Asked Patel: 'Would not that give in the future the assurance and security to everyone in this Colony that even when those six European members sit in this Council they are not going there as the sole representatives of a small microscopic minority but they are going there as the representatives of the people in their constituency?'

Fijian leaders opposed any change. Ratu Edward Cakobau likened the prospect of reforming the political system to a box fish, dangerous and deadly poisonous if not handled properly. 'If we begin tampering with our constitution it will soon extend and poison our political life.' What guarantee was there that an expanded Council would attract good people, assuming that there were some who 'were not only willing but fitted to become such legislators, and whose views and influence will be real influence for good.' If we accept change now, Ratu Edward continued, 'what is there in the next ten years to prevent the demand for a new form of democratic government,' or block the introduction of the dreaded common roll. In view of all these uncertainties, Ratu Edward concluded: 'The only thing that can stop it [common roll] would be to hold on to our present constitution. The Fijians have every confidence in the Crown and we look to the Europeans, whom we have always supported, to ponder and not to give way too easily to democratic ideals that are unsuited to a country containing three major races who differ in language, culture and religion; and these races will never combine to unite as one people.' Was this realism or reactionary resignation? Whatever it was, the motion was defeated.

Defeated but not forgotten, for the constitutional issue reared its head again three years later when Ragg introduced an almost identical motion in September 1948, demanding an expanded Council 'in view of the increasing population of the Colony and the advances made in the social, educational and economic spheres by its peoples.' His proposed Legislative Council would consist of six nominated and four ex-officio members (Colonial Secretary, Financial Secretary, Attorney General and the Secretary for Fijian Affairs), and 18 elected members, 
six from each of the three ethnic groups. The Executive Council would have, in addition to the four ex-officio members, three elected members chosen by the governor from a panel of six submitted by the elected members of the Legislative Council and one nominated member chosen by the Governor to represent special interests.

Ragg was in a combative mood, promising to pursue the matter of constitutional reform in 'vigorous and realistic manner,' not 'in a dilettante manner, and approached from an academic point of view.' He had an added authority to speak on this motion, as the president of the newly formed European Electors' Association. He informed the Council that he had already petitioned the Secretary of State of the Colonies with the substance of the motion in February 1948, which had been rejected on the grounds that there was no evidence of widespread support for a constitutional change in the colony. His proposal for a plebiscite to test the opinion of the people had been rejected. He had taken the advice of the European nominated member to present his case in the Council, though he knew 'as sure as I am standing here' that his proposal would be defeated 'because the government has the whip hand and does not want any change from the status quo.'

Ragg traversed the familiar opposition to the system of official majority in the Legislative Council which, he said 'will preserve dictatorship and obstruct the attainment of the people's legitimate political demands.' He then raised the issue of enfranchising the Fijian people. He deplored the 'archaic control' of the Fijian Administration, which gave the government 'an easy way of controlling the Fijians and to appear to give them control of their own affairs.' Not only the government but the chiefs also wanted to retain the present system because they feared that 'any departure from it [would] weaken their power and impair their privileges.' He implored the Council to emancipate the Fijians from a system 'which is barbaric in origin and outmoded in time,' which if it was continued any longer would 'lead to their domination and ultimate elimination by other races.'

What about the Indian community in Ragg's proposed scheme of things? The Indian threat, which to Ragg was real enough, should not be used to delay political reform. The Indians were a menace, he agreed, but the Imperial government was committed to preserving the paramountcy of Fijian interests, Europeans had certain prior rights - after all they had discovered, colonised and civilised the islands - and consideration of 'Imperial prestige demands that the European element in the population should be preserved.' No British government, whether Labour or Conservative, could 'ever be so base as to repudiate the solemn promises made in the name of Queen Victoria by giving political ascendancy to a section of the our population whose fatherland is India and whose first loyalty is to that country.' 
European members of the Council opposed Ragg's motion. They questioned Ragg's credentials and his authority as well as the timing of the motion. The government had not abused its numerical strength in the council which Hugh Ragg thought was 'unbiased, unprejudiced, with many years of experience in such matters.' Any change toward democracy was unwise, indeed disastrous. Maurice Scott agreed, as also did the Fijian members. Ratu George Toganivalu asked: 'Why change the system of government when that system is working satisfactorily?' Ratu Tiale Vuiyasawa was more pointed. He thought Ragg was in some kind of a trance whose divine injunction was 'Change the Letters Patent, change the constitution, and all will be well.' His own people were not ready for change. Joeli Ravai opposed the motion on the grounds that a more democratic system 'does not yet suit the Fijian taste.' Ratu George Tuisawau thought Ragg's suggestion of universal franchise for the Fijian people 'open to abuse and corruption because there is nothing to prevent undesirable members of my race from standing for election and, when they succeed, playing fast and loose with Fijian politics to the detriment of my race.' Although he did not realise it, Ratu George had reinforced one of Ragg's contentions that Fijian chiefs were afraid to let commoners have a taste of democracy for the fear that their own position might then be undermined.

Vishnu Deo agreed with the basic principle of the motion, but not with its supporting arguments, especially the extraneous anti-Indian material Ragg had introduced in support. He reminded the Council that even though they found the system of communal representation abhorrent, the Indian members had not, since 1937, moved a motion for constitutional change. 'All the resolutions that have been brought up in this Council were brought up by the European members and they find pleasure in bringing up such a resolution in order to throw dirt at us, the Indians in Fiji.' The bogey of Indian domination was just that, a bogey. The Indians, Deo said, wanted equal representation, not proportionate representation, despite the fact that they were numerically the dominant community in Fiji. Deo then moved an amendment that in view of the progress made by the increasing population of Fiji, a committee be appointed to consider and report on the desirability of granting the peoples of the Colony a greater measure of political control over their own affairs and to recommend amendments necessary in the constitution providing the Government of Fiji and the representation of the peoples on the Legislative and Executive Councils thereof.'

A.D. Patel seconded Deo's amendment, devoting a large part of his speech to Ragg's remarks and fears about the Indian community. He emphasised that the 'three races were thrown together by destiny and by the logic of history' It was to the credit of the three groups who had thus far 'worked and co-operated and made this paradise of the Pacific that is Fiji.' So why raise the 'unnecessary bogey 
that will suddenly make us start flying at each other's throats and turn these islands into an Armageddon?' Indians were not intruders in Fiji, Patel reminded his listeners. They had been brought to Fiji under a contractual agreement with the promise, given by the Imperial government that 'those Indians who came here would have rights no whit inferior to those enjoyed by other subjects of His Majesty'.

He was referring to Lord Salisbury's Despatch of 1875. According to that document, the then Secretary of State for the Colonies had promised that if the Government of India agreed to facilitate the emigration of Indian indentured labour to the colonies, the migrants would enjoy rights equal to that enjoyed by the other British subjects. As it happened, the Government of India referred the matter of emigration to the provincial governments, which declined to take an active role in promoting emigration. So the matter rested there. Was the Despatch then a dead letter? Hardly, for emigration continued, with the understanding that those time-expired migrants who settled in the colonies would enjoy all rights accorded to British subjects.

But Salisbury's Despatch was not all, Patel reminded the Legislative Council. 'Even after the system of indenture was abolished,' Patel noted accurately, 'a high official and one of the heads of the Christian churches here was sent to India to persuade the government and the people of India to send more people to come and settle in Fiji, telling them that they would get lands, that they would get the same privileges and the same treatment as other peoples resident here; the people who had fulfilled their contracts under the indenture were given similar promises and were encouraged to settle down here, and an overwhelming number of the present Indian community are the descendants of those people to whom those promises have been made.' Even before then, the Crewe Commission in 1910 had concluded that the whole tenor of the correspondence between India and the colony shows that it was on this condition [equal civil rights] that indentured immigration in Fiji has been allowed in the past, and any measures leading towards lowering the political status of the immigrants or reducing their economic freedom would, in our opinion, involve a breach of faith with those affected. ${ }^{\prime 19}$

Ragg, in the course of his speech, had remarked on the danger that the 'Asiatic religious concept' posed for the Fijian people. But what was there in Asiatic religious concepts that threatened the central tenets of Christianity, asked Patel? 'I look upon envy and hate as evils which, if one cannot eradicate altogether from one's nature, one must at least learn to suppress. Is Christianity going to preach any ideal which is contrary to that?' he asked. Did Christianity have any quarrel with his belief, as a Hindu, in the fatherhood of God and the 
brotherhood of mankind, or with the view that as all rivers flow into the same ocean, all religions lead to the same truth? 'Is there anything in our life here or in the way we socially and culturally mix with our neighbours belonging to the other two great communities, is there anything in which you can say that we have done any harm to the Christian principles of life?'

The Indian community had made progress and increased in numbers, Patel agreed, but how did that constitute a menace to the other communities? Indian leaders had long accepted the view that Fijian interests should be paramount in Fiji. They had accepted that 'the rights and privileges of the minorities ought not to be and must not be an iota less than the rights and privileges enjoyed by the majority' By the same token, however, Patel argued, the minorities had 'also to appreciate and realise the fact that they cannot expect or hope for privileges and rights in excess of those enjoyed by the majority.' Yes, he believed that a common franchise was the way forward for Fiji, but he reminded the Council that common roll could not be imposed on anyone; it could only come about 'when we will be fortunate enough to win the confidence and trust of the other two communities, when they themselves will freely and voluntarily come and say, the time has arrived when we are all one; we are not afraid of you because you are predominant in numbers and we can willingly come together under a common franchise.'

Those who opposed democracy showed only one thing, Patel said: 'We are afraid of our own fellow beings.' But the world was marching on and 'however much we might like to stop where it would serve our individual interests and purposes, it is not going to stop or give us any consideration.' A new spirit had been created in Fiji as a result of the war and increased contact with the outside world, and it was time that 'we provide new bottles for new wine.' The Fijian community could not forestall change forever. The present set up had created 'an admirable type of cultured and level-headed leadership,' like Ratu Sukuna 'who in any community anywhere would be an ornament.' Nonetheless, he urged the Fijian leaders to realise that 'the time has come when they should produce not only great chiefs but great commoners' as well, whose aspirations, whetted by the post-war influences, could not be ignored indefinitely.

Patel implored the unofficial members - the official members were barred from taking part in the debate and voting upon it - not to be carried away by the heat and emotion generated during the debate. 'We have got to consider the possibilities of constitutional changes having due regard to all problems and difficulties that the presence of three racial groups in this Colony entails.' He urged his fellow councillors to 'put our heads together and to try in all sincerity to find a solution for the present problems.' Dialogue and dispassionate discussion among them was the only way to achieve this. It would be another 15 years before the constitution would be revised and the franchise expanded. 
Aime Ragg assured everyone that in moving the motion for the expansion of the Legislative Council, he was 'actuated by the highest motives.' Sowing the seeds of discord in the community was furthest from his intentions. But Ragg was a master of double-speak. He was not anti-Indian, he assured the Indian leaders, yet in the 1950s, he repeatedly petitioned the Colonial Office in London with strange proposals to limit the Indian population. Among his more dramatic proposals was his plan to repatriate Indian people. His colleague, retired inspector of Indian schools in Fiji, A.W. Macmillan, wanted to resettle a large part of Fiji's Indian population in the Highlands of New Guinea, a strategy which would help solve Fiji's 'Indian problem,' bring an undeveloped area of New Guinea into production of cash crops with Indian labour and, in creating an Indian settlement in the Highlands, erect a useful buffer between the hungry masses of Asia and the white dominions of Australia and New Zealand. ${ }^{20}$

But perhaps the best, certainly the most public, example of Ragg saying one thing and meaning something else was his motion in the Legislative Council in July 1946 regarding the future of the Fijian people. This self-appointed guardian of Fijian interests argued that Britain had neglected its obligations to the Fijian people. The terms of the Deed of Cession had been neglected, and were now in need of reassertion. His motion read: 'That in the opinion of this Council the time has arrived - in view of the great increase in the non-Fijian inhabitants and its consequential political development - to emphasise the terms of the Deed of Cession to assure that the interests of the Fijian race are safeguarded and a guarantee given that Fiji is to be preserved and kept as a Fijian country for all time. ${ }^{21}$

The wording of the motion was uncontroversial enough, but it soon became clear that by non-Fijians, Ragg actually meant the Indian community. Europeans, in his view, were saviours of the Fijian people, the co-trustees, with the Imperial Government, of the Fijian 'race.' The Europeans had 'colonised and transformed Fiji from a barbarous country into a civilised one; they instituted a stable Government; they are responsible for the economic development of the Colony.' But the Indians? They were a 'distinct menace to the Fijian race.' They wanted to 'usurp the heritage of the Fijian people.' They desired nothing less than total racial domination of Fiji. Numerical domination apart, there was another feature that was repugnant about the Indians, Ragg went on. They were 'an alien race which, due to heredity, customs, religion and environment, has not assimilated and will not assimilate with the Fijians.' Their aspirations had to be checked, and government obligations to the Fijian people reaffirmed before it was too late.

20 See Broken Waves, 143.

21 Legislative Council Debate, 16 July 1946. 
The motion provoked heated debate. All the Fijian members of the Council supported the motion, expressing alarm at the prospect of total subjugation by the Indian community. 'We Fijians have heard of King Canute,' said Ratu Etuate Mataitini, 'and we do not propose to follow his example nor can we, as representatives of the Fijian people, sit idly by.' W.G. (Tui) Johnson agreed, faulting the government for not dealing severely enough with self-seeking agitators in the Indian community, who were poisoning the minds of their people with strange notions of political equality, and for not reminding the community of their good fortune to be in Fiji where they had made progress they could only dream about in their ancestral homeland.

A.D. Patel listened intently as speaker after speaker rose either to oppose or support Ragg's motion. Then, in his contribution to the debate, he made a remarkable speech. It was A.D. Patel at his best: sharp, eloquent, clinical, withering in his attack. It was a speech that was to be widely remembered in the Indian community, long after the debate itself had been forgotten; even Aime Ragg, the mover of the motion, complimented Patel on his 'very able speech,' commenting that 'we must admire the sincerity with which [Patel] has put forward the claims of the Indian people.'

Patel began by noting the obvious, that in Ragg's construction, 'non-Fijian inhabitants' actually meant 'Indians.' Ragg's motion, Patel suggested, implied three things: that because the government had either forgotten or overlooked the terms of Deed Cession, there was an urgent need for a reminder, that the time had arrived to look to the Deed to safeguard Fijian interests, and that on account of the increase in the population of the non-Fijian inhabitants, it was felt necessary to reiterate the terms of the Deed. But which terms and how many of the terms were in need of reiteration? asked Patel. He went systematically through the document. The preamble, he pointed out, simply said why the Fijian chiefs had ceded Fiji to Great Britain in the first place. They had done so to promote civilisation and Christianity in the islands, increase trade and industry, and foster good and orderly government. Upon receiving these guarantees, they ceded the islands unconditionally. All these conditions had been 'scrupulously fulfilled,' Patel argued.

He then dissected the covenants of the Deed clause by clause in the manner of a trial lawyer in a court of law. The first covenant merely handed over the sovereignty and the possession of the islands to Queen Victoria, her heirs and successors. The second covenant handed over full and unlimited powers to Queen Victoria and her heirs and successors to determine the form and the constitution of the government and the administration of the laws of the colony. No one could argue that there had been any departure either on the part of the government or the non-Fijian inhabitants in respect of that provision. Covenant three, which provided for a temporary and provisional government pending 
the establishment of the British administration of Fiji had been fulfilled and finished. That covenant was now a dead letter. There was no reason to quarrel with the fourth covenant of the Deed which vested all surplus lands of the Colony into British hands, for that had already been accomplished. Surplus land was all non-alienated land and others not in actual possession or occupation of the Fijian people. Covenant five authorised the Crown to acquire, upon payment of compensation, any land from the owners for public purposes. No one, including Ragg and the Fijian members, had complained that the government had acted unfairly. Covenant six merely transferred the public buildings, stores, and other such property to the British Crown. That had already been fulfilled, and a matter of the past.

Similarly, promises in covenant seven had been fulfilled. The government had already recognised the rights and interests of the Tui Viti and the other high chiefs 'so far as is consistent with British sovereignty and colonial form of government.' Their financial liabilities and engagements had already been examined and dealt with 'upon principles of justice and sound public policy' Equally, the government had already 'investigated and equitably adjusted' the claims to titles of land, pensions and allowances of the Tui Viti, other high Fijian chiefs and others holding office under them. 'So what in God's name is left in the Deed of Cession that [Ragg] wants to be specially emphasised under this motion?', Patel asked. 'He may throw dust in the eyes of others but I refuse to be blinded by any emotion or feeling or allow my reason to be carried away by prejudice. That is the Deed of Cession that has been the subject of all this mud-slinging and hot air in this Council.' If the worst that could be said about the Indian people was that they did not intermarry with the Fijians despite the shortage of Indian women, that in the face of all the adversities they had increased in numbers, that they were corrupting Fijians because they, the Indians, were paying high rent to them - 'if this is the worst that our adversaries can say about us, thank God we have acquitted ourselves well in this colony.'

All the Fijian signatories to the Deed of Cession were alive when Indian immigration began, but did any of them complain that the introduction of Indian labour broke the covenants of the Deed or committed a breach of faith with those who had handed over the Colony into their hands? The truth was that the Fijian people and the government understood and appreciated why the Indians were brought to Fiji. Patel continued: 'They worked here for those people who gobbled up half a million of acres of freehold land from the Fijian owners and we came and undertook to work under a system which, thank God, saved the Fijian race from the infamy of coming under. My community worked under that semi-servile state. As a matter of fact, if anything, the coming of my people to this country gave the Fijians their honour, their prestige, nay indeed 
their very soul. Otherwise I have no hesitation in saying that the Fijian people in this Colony would have met with the same fate that some other indigenous races in parts of Africa met.'

Fijian and Indian communities had rather more in common than many in the colony thought, Patel continued. Turning to the Fijian members of the Council, he said, 'We have lived with you and mixed with you, hobnobbed with you all the time. We have never looked upon the Fijians as our inferiors because they are Fijians.' The Indians paid rent for the land they leased, and from the income they produced everyone, including the Fijians, benefited. And he reminded his listeners that it was the Indian leaders who had fought for legislation to improve the condition of the ordinary workers of the country, and for the removal of the 'obnoxious and odious racial discrimination in Government service.' Indians had never advocated taking land away from Fijians. All they wanted was security of tenure. 'We ourselves have advocated the principle that the interests of the Fijians must always remain paramount in this Colony, that where those interests come into conflict with our interests, we readily agree to make our interests subservient to theirs.' Indians had never aspired to dominate over any group, but Patel warned, 'let it be remembered that we will not tolerate domination from others as well.'

Between moving his motion and Patel's speech, Ragg had diluted his motion to read that 'in the opinion of this council the time has arrived to emphasise the terms of the Deed of Cession to ensure that the interests of the Fijian race are safeguarded.' Patel was unsatisfied. Why the phrase 'time has arrived,' he asked? Ragg then further amended his motion to read that 'the Government and the non-Fijian inhabitants of this Colony stand by the terms of the Deed of Cession and shall consider that document as a Charter of the Fijian people.' Thus amended to an innocuous form, the motion was passed unanimously. But the bitterness and hostilities generated by the debate lingered on. 


\section{Chapter 6: Interregnum}

If the Fiji Indians do not open their eyes in time, they will be met with the fate of an ostrich burying its head in the sand.

A.D. Patel, 1952

A capacity for enjoyment is probably the most valuable gift that anyone can possess.

A.D. Patel, 1958

By 1950, A.D. Patel had become one of the most influential and widely known figures in the Indian community and in the public affairs of the colony generally. His work in the Legislative Council was well known. His reputation as the Colony's leading criminal lawyer was securely established, his only rival in the field being Philip Rice, whom Patel himself respected. In 1946, Patel travelled to India as the Fiji Indian delegate to the Indian National Congress at Meerut, where he met future Indian Prime Minister Jawaharlal Nehru and discussed the situation of the Fiji Indians with him and other leaders of the Congress. The following year, while still in India, Patel married Leela Ben, an attractive and graceful woman, the daughter of Professor B.N. Patel, an acquaintance of A.D's She was 20 when she married; Patel was 42 . They returned to Fiji a few weeks later and started their life together in Nadi. For Leela, the early days in Nadi were a nightmare. Making the transition from the bustling metropolis of Bombay to the bush-village atmosphere of a rustic Fiji town was not easy. She had no family or friends or acquaintances in Fiji to help her make the transition and to ease the pain of social isolation. She found the whole environment claustrophobic and constricting and yearned to return to her more cosmopolitan homeland.

Nonetheless, the 1950s were the happiest time for the Patels. They shared each others' interest in gardening, music, food and cultural pursuits. Children came, first Atul in 1948, then Pratibha and Dhimant followed by Vasantika and Amita. In 1952, the Patels made a leisurely boat trip back to India, via Australia, taking in sight seeing tours at Sydney, Melbourne, Adelaide, and Fremantle on the way. It was wonderful to get away 'from the petty vexations of life in Fiji,' Patel wrote in his diary. Perhaps for the first time in his life, Patel was enjoying a semblance of stability and inner emotional tranquillity. His law practice was flourishing, he read widely and wrote extensively and elegantly on a whole range of subjects. He gave speeches which still survive in the memories of those who heard them. He served on official committees such as the Education Advisory Board to which he was appointed in 1957 and on the Library Enquiry Committee. He was a member of the Camera Club of Fiji. In 1955, he took out 
a prospecting licence with Pandit Ram Sumeran and Ram Dev on some four hundred acres of land. Patel wanted to start citrus farming in Fiji, which proved to be a financial disaster. Then there were the regular readings of the Bhagavada Gita, the Upanishads and the Gitanjali organised by the Prarthana Sabha of Nadi, formed in 1954, whose members, besides Patel, included Swami Rudrananda, H.M. Lodhia, Sundarji Kalidas, Bhaskaran Iyer and R.O. Sharma. Patel was a regular chief guest at various sports carnivals. In 1956, he donated the Atul Kumar trophy to the Nadi Soccer Association, named after his eldest son. In the midst of all this activity, Patel also somehow found time to found newspapers, establish a high school and manage a string of Sangam primary schools throughout Viti Levu.

A major reason for this happy state of hectic activity was that Patel was out of politics. He had been defeated in the 1950 election for the Legislative Council by a relative newcomer to the political scene, the first Fiji-born Indian lawyer, Tulsi Ram Sharma. Patel polled 1,850 votes to Sharma's 2,340. Sharma served only one (three-year) term in the Council, was defeated at the next polls three years later, and then retired to a quiet private life in Lautoka, never to be heard from again. In 1953, Patel was defeated again, this time by Ajodhya Prasad of the Kisan Sangh, Patel's most powerful and persistent opponent in sugar cane politics since the late 1930s. Prasad polled 2,718 votes to Patel's 1,919. Two successive defeats depressed Patel and he did not contest the next three Legislative Council elections. He would enter the Council again a decade later in 1963. Governor Sir Ronald Garvey wanted to nominate Patel to the Legislative Council, but each time he was approached, Patel declined the offer. If he could not get into the Council as the people's elected representative, he would not go there at all, and certainly not by the 'back door' of nomination. To become a nominated member in the Council would make a mockery of the principles he believed in, Patel told the Governor.

Why did this man, who was widely admired for his political abilities, and who had been the Indian member of the Executive Council from 1947 to 1950, fail at the polls? The principal cause of Patel's political eclipse in the 1950s was the growing personal and ideological rift between himself and Vishnu Deo. As we have already seen, Vishnu Deo was an influential and effective politician, with a wide network of powerful friends and supporters throughout the colony. One crossed swords with Deo at one's own peril. Many issues divided the two leaders. One, which also aroused great emotion in the Indian community in the post-war years, was prohibition. The government proposed to relax restrictions on liquor consumption, and wanted to gauge public opinion on the subject. ${ }^{1}$ Vishnu Deo, being a devout Arya Samaji and a strict teetotaller and a dedicated prohibitionist, opposed the move. Liquor was a drug, and if other drugs could

1 See Legislative Council Debate, February 1946. 
be prohibited, why not liquor? Hindus and Muslims were forbidden by their religion from drinking liquor and, Vishnu Deo informed the Council, most of them supported total prohibition. He was convinced that alcohol was one of the great curses of mankind, destroyer of families and fortunes. Many in the Indian community did agree with Deo. Among them were J.F. Grant of the Indian Reform League, J.P. Maharaj, President of the Arya Samaj, Phuman Singh of the Sikh Gurudwara Committee and Kifait Husain of the Fiji Muslim League. Five hundred Indian women gathered at the Suva Sangam Hall and supported Vishnu Deo's position. ${ }^{2}$

Patel was on the opposite side in the debate. He did not drink either, beyond the occasional dry sherry at social occasions, but he opposed prohibition. He argued that it is self-denial that turns a man into a saint, not prohibition; prohibition only succeeds in turning a man into a hypocrite.' Experience in the United States, and even in certain parts of India itself which had tried prohibition, showed that all such experiments failed. In India, he said, 'bootlegging in the cities proper was going on galore and prohibition had rather become a laughing stock.' If it didn't succeed in India, it was hardly likely to succeed in a small place like Fiji. And why should prohibition be enforced only against the Indians and Fijians? As far as the Fijians were concerned, Patel said, the "matter should be left entirely to the Fijians themselves to decide,' perhaps through the newly created Fijian Affairs Board. As for Indians, drink was not new to them; they had been drinking liquor long before Europeans. Any attempt to enforce prohibition amongst Indians would be met with resistance, he warned. It would give rise to distilling illicit liquor and the use of methylated spirits as a substitute.

Then there was the racial aspect to consider. Why should Indians, or the 'responsible classes' among them (doctors, businessmen, lawyers) have to apply for a liquor permit when Europeans were exempted. 'Indians understand their responsibilities and their obligations in life just as any responsible member of any other society, and naturally they all feel that this is a sort of indignity cast upon them.' Vishnu Deo remained unconvinced, but Patel's assertion that even the Hindu gods had partaken of the golden liquid aroused considerable commotion among the more religious-minded sections of the community. What Patel had said was tantamount to sacrilege: how dare this Gujarati say that Hindu gods drank alcohol?

Another issue on which Vishnu Deo and A.D. Patel differed strongly was language education. ${ }^{3}$ It has to be said that both men were passionately committed to the cause of education. Vishnu Deo was the leading light in the Arya Samaj's quest for

2 A petition was sent to the Secretary of State for the Colonies on 8 January 1947 by these groups urging total prohibition.

3 CSO F28/10. 
the expansion of educational facilities in the Indian community. Patel, too, was a committed educationist. As early as 1938, he had called for the introduction of compulsory education, the provision of technical and vocational training, the establishment of intermediate and secondary schools and the admission of a prescribed percentage of Indian children to European Grammar schools. ${ }^{4}$ Both men saw education as a vital instrument not only for earning a decent livelihood but for cultural and social liberation of the Indian community. On the question of the language of instruction in schools, however, the two disagreed. For Vishnu Deo, the teaching of English in the primary schools of the colony was a matter of priority. Vernacular languages should be taught to standard four or five, but thereafter instruction should be in English. He realised the obvious fact that English was critical for jobs in government and the private sector.

English should be taught in schools, Patel agreed, but not at the expense of the vernacular languages. It was not simply a question of language teaching, it was the question of preserving one's cultural identity. In this, Patel was expressing the feelings and apprehensions of the minority cultural groups in the Indian community. North Indian children would learn Hindi and English, but what about the mother tongue of other children, South Indians, for example, or Punjabis and Gujaratis, he asked? One should progress in every sphere of life, but not at the expense of one's cultural identity. For the North Indians, the majority in the Indian community, this was not an issue, but for the minorities it was. It will be recalled that Patel had petitioned the government in 1937 to bring Telugu and Tamil teachers to Fiji.

The increasing political rift between Patel and Vishnu Deo came to a head in 1948, when the question of selecting an Indian elected member of the Legislative Council for the Executive Council came up. ${ }^{5}$ The existing practice was for the elected members of the Council to forward a single name for the Governor's appointment. The five members in the Legislative Council that year were Patel, Vishnu Deo, M.S. Buksh, Ami Chandra and James Madhavan. Both Patel and Deo put their names forward. Madhavan supported Patel and Chandra backed Deo, leaving Buksh as the only uncommitted member. Madhavan was a South Indian and with the Sangam while Chandra, like Visnhu Deo, was an Arya Samaji. Buksh did not see himself as being suitable for the Indian seat on the Executive Council. In his view, the best candidates were Patel and Vishnu Deo. Sensing Buksh's reluctance and hesitation, Patel nominated Buksh, whom Deo openly considered an unworthy candidate. As the senior Indian member who had been in the Legislative Council continuously since the 1930s, Vishnu Deo considered a seat on the Executive Council to be his prerogative. Buksh, hurt by Deo's attitude, reciprocated Patel's gesture, and supported his

$4 \quad$ Fiji All Indian Conference, November 1938.

5 This is based on interviews. 
nomination. As Buksh put it, 'Un ka pehanaya hua hoar unko hi pehana diya.' [I garlanded him with the garland he offered me]. If Vishnu Deo had agreed even to talk to him, Buksh said later, he might have reconsidered his position. ${ }^{6}$

Patel had out manoeuvred Vishnu Deo and won the coveted Indian seat on the Executive Council, but it turned out to be a pyrrhic political victory for him. For in the late 1940s and the 1950s, Vishnu Deo was organisationally the best prepared Indian politician in the colony. And he would use his extensive contacts to keep Patel out of the Legislative Council. There was not a single major Indian organisation which did not come under Deo's influence or have his signature on it. There was, first of all, the Arya Samaj, the close-knit, influential reformist Hindu sect which, although a minority among the Hindu population, counted among its members a significant portion the better educated and wealthier sections of the Indian community. Vishnu Deo was its unrivalled intellectual and political leader. In recognition of his stature, the Central Indian Organisation of Fiji, founded by Vishnu Deo, bestowed upon him the title of 'Jan Ratna,' the People's Prince (Jewel) in November 1948.

The Arya Samaj also organised a number of grassroots social and cultural organisations which further strengthened Deo's influence. These included Gram Sangathan (Village Associations), Navyuwak Sabha (Young Men's Association), Swayam Sevak Dal (Self-Help Organisation), Mahila Mandal (Women's Society), and various farmers' and workers' unions. On 2 May 1948, Vishnu Deo launched the Central Indian Organisation of Fiji (Bhartiye Janata Ki Kendriye Sabha), of which he was the president and Udrek Singh and Dr C.M. Gopalan and his wife were the vice-presidents. ${ }^{7}$ The organisation's principal constituency was the Indian community in southern Viti Levu, but its goals were wide-ranging. Among other things, the organisation wanted to protect and promote the welfare of the Indian community, lift the position of Indian women by giving them the franchise and recognising the principle of equal pay for equal work, organise programs in adult and community education, provide relief and assistance to the needy and, 'to nominate and support as and when so determined candidates for elections to the Legislative, Municipal and Town Councils and to other bodies for which elective principle is or will be applied for the representation of the people.' The organisation had an elaborate constitution which specified its operational procedures, membership, and the composition of its decisionmaking parts.

In a very real sense, the Central Indian Organisation of Fiji was the first political party in the Indian community, and Vishnu Deo was its founding father and its

6 It has been suggested that Buksh may have been leaning towards Patel because he, Buksh, was a sympathetic friend of the Sangam.

7 Based on papers relating to these organisations in the papers of K.L. Gillion (in my possession). 
guiding light. With such a strong and inclusive organisational base, Vishnu Deo became not only the king-maker in the Indian community but the king as well. From 1950 to his retirement, Deo remained a formidable, though a somewhat mellowed, moderate figure. But he still pulled the strings. To Deo's organisational strength, Patel had no answer. Instead of relying on organisations, Patel hoped to win elections on the strength of his ideas and the force of his advocacy. He was still a popular and effective politician, as the closeness of the election results showed; but it was Vishnu Deo and the men he chose and supported who triumphed. 'Jab Apna Hai to Gair Kyun' [Why another when we have one of our own] was a standard rally in the 1950s. In 1956, Vishnu Deo finally entered the Executive Council, defeating James Madhavan who had succeeded Patel. Three years later, he would retire from politics.

Vishnu Deo was an important source of Patel's problems, but there were others. Patel's close identification with the cause and the philosophy of the Indian National Congress also played a part. 'My sympathies with the Congress are well-known in this Colony,' Patel admitted publicly. ${ }^{8}$ It was indeed, and amply demonstrated at public gatherings, especially at the Bharat Mata Day (Mother India Day) celebrations when the Indian national anthem, 'Bande Matram' was sung and speeches were made on Indian politics, culture and history. It was only natural for Patel to identify with the currents of Indian politics. As already mentioned, he was the Indian community's representative to the Meerut Congress meeting in 1946. And then there were emotional and cultural attachments as well. More than this, however, Patel was convinced that the political destiny of the overseas Indians was closely linked with India's position in the international community. For him, India's independence could only lead to an improvement in the position of the Fiji Indians. The Colonial Office could ignore the plea of the Fiji Indian community, but it could not ignore the voice of the Government of India. When India spoke, London listened. It was, after all, the pressure from India that had precipitated the abolition of indenture; and it was pressure from India that had forced a reluctant colonial government in Fiji to enfranchise the Indian community and address its social and economic concerns. After independence, the Indian lever weakened, which Patel regretted.

Some of Patel's Fiji-born younger colleagues - the Deokis and the Grants - also opposed Patel's politics. Fiji was their home, not India, they said in letters to the press, and demanded that the currents of Indian politics and communal thinking should not be allowed to pollute the shores of Fiji. Especially opposed to Patel were the more westernised members of the Indian middle classes who had gained a measure of success and security through close identification with the local political and cultural elite. Patel reminded them of their Indian heritage, and worked for its preservation and propagation. He wanted the Fiji

8 Legislative Council Debates 21 February 1946. 
Indians to acknowledge their heritage and be proud of it. As he said in 1952: 'Centuries before the birth of Christ there flourished in India a civilisation, which has been an enigma and a wonder to the historian.' Modern sciences like mathematics and medicine had their beginning in India. 'On the sacred soil of India has been born a galaxy of world figures, like Ram and Krishna, Buddha and Gandhi, Ramakrishna and Vivekanand, who have made their impress [ion] on the thought and life of vast masses of men in the world. ${ }^{9}$ The Fiji Indians should consider it their moral and cultural duty to pass on the message of Indian civilisation to their fellow citizens of other races. But the Fijiborn were made of a different stuff; their social universe and world view were fashioned by a different historical experience, social background and cultural outlook. Pragmatic as always, un-beholden to tradition, they were on their way to becoming a part of the establishment in the public service and in the professions. Patel's relentless criticism of colonialism was an embarrassment to them. Moreover, many were not unhappy to cut their umbilical cord with their ancestral motherland. Most had never visited India, and most never would. The Fiji-born-India-born or Gujarati and non-Gujarati conflict, which had existed for a long time, was still an important factor in Fiji Indian politics.

Apart from the Indian middle classes, Muslims, too, disliked Patel's close identification with Indian politics. The communal tides of the Indian subcontinent continued to lap the shores of Fiji. Muslims, who had long advocated a separate roll for themselves because, as they said, they were racially different from the Hindus, seized upon the partition of India as proof enough of their claim for a separate identity. Patel opposed the Muslim demand for a separate electoral roll, as did Vishnu Deo though perhaps not as tenaciously; but Patel bore the brunt of the Muslim separatists' anger because of his Indian connection with and active sympathy for Congress politics. In fact, in 1950, the Fiji Muslim League officially backed Patel's rival, Tulsi Ram Sharma, in the Legislative Council elections. Said Hasan, the Indian nominated leader in the Council, spearheaded the anti-Patel campaign in the late 1940s. Nor was Patel's position helped by the new Indian High Commissioner to Fiji, Samuel Alfred (Altef) Waiz, an Indian Christian, who advised Fiji Indians to keep away from political developments in India. Fiji was their home, and their primary loyalty should be to that country. He, too, was loyal to Fiji, Patel responded, but pride in Indian culture and civilisation should not be construed as disloyalty to Fiji, and defended his view that Indian culture had something to contribute to the social and moral development of the colony. Waiz and Patel clashed several times on public occasions, especially after Waiz applauded Vishnu Deo's leadership abilities. Both the Fiji Muslim League and the Arya Samaj found a common cause in opposing Patel and supporting Tulsi Ram Sharma in the 1950 election. ${ }^{10}$ It may be of some interest to note that in 1952,

9 Pacific Review, 8 August 1952.

10 Pacific Review, 9 May 1950. 
Vishnu Deo told John Dugdale, the Under Secretary of State for the Colonies, that he would not oppose a single separate seat for Muslims to be elected by members of that faith alone.

Apart from Muslims and sections of the Fiji Indian middle class, there were some members of the South Indian community who also moved away from Patel. Patel was the General Manager and Legal Adviser to the Sangam until 1953 (when Swami Rudrananda became the General Manager and Patel the Legal Adviser). There had always been some South Indians who accused Patel of simply using the South Indian community for his own political purposes. Some leading South Indians were already in the anti-Patel camp, such as C.M. Gopalan and K.S. Reddy. Then in 1951 an event occurred which intensified the suspicion of those already distrustful of Swami Rudrananda and A.D. Patel. In that year, Swamiji attempted to amalgamate the Sangam and the Ramakrishna Mission into a single unit following unanimous resolutions authorising the affiliation of the two bodies, passed in 1947 and again in 1950. ${ }^{11}$

Some South Indians in Viti Levu saw Rudrananda's actions as no more than a blatant attempt by the Mission to take over the considerable assets of the Sangam. The Swami was a swill, they said, and even wrote to the Ramakrishna Mission in Calcutta protesting his actions and asking for his immediate recall. Sadhu Kuppuswami, the founder of Sangam, defended Rudrananda: 'It is my wish to make the Sangam a branch of the Mission. In this connection it is neither a trickery of the Mission nor of Swami Rudrananda.' ${ }^{12}$ In truth, it was neither greed nor graft that lay behind Rudrananda's decision. If anything, it was ineptitude, his action the result of bad advice and complete unfamiliarity with the way business works. He saw absolutely no problem in diverting funds from one branch of the same organisation to accomplish a project in another. For Rudrananda, the Sangam and the Ramakrishna Mission had identical aims, so what was the harm in amalgamating the two? In any case, more important than the sectional interests of a particular community was the welfare of the entire Indian community. The Swami had a universal, not a narrow communal vision. But his opponents thought otherwise. It was the South Indians who had collected the funds, which, they said, should be used first for their benefit before anyone else's. They should be consulted before their assets were moved or sold. The protests halted the amalgamation plans, and severely divided the South Indian community for many years. ${ }^{13}$ Eventually a compromise was

\footnotetext{
11 Pacific Review, 21 November 1953.

12 Published in Jagriti under the heading 'Dhusht Prachar,' (Evil Propaganda). See also G.K. Naidu's statement in the Pacific Review, 14 Nov. 1963: 'There is no conflict. The aims and constitutions of both the organisations are similar. Interested people who are inimical towards the Ramakrishna Mission and the Sangam try to see conflict where none exists.'

13 K.S. Reddy proposed a 'Cultural Societies Restriction Bill (Fiji Royal Gazette, 19 Aug. 1954) which prohibited any society or company from amalgamating without the consent of the Governor-in-Council, whose decision would be final. Reddy was one of those who led the fight against Rudrananda's plans.
} 
reached when the Sri Vivekananda High School was transferred to the Mission and Sangam was left to run its own separate schools. But the bitterness of the dispute lingered; even today it arouses considerable emotion.

So, without a strong organisational base, and with religious, cultural and petty disputes wrecking the Indian community, Patel retired to a quiet life in the tranquil political wilderness in the 1950s. He occupied his time in a variety of ways, as already noted at the beginning of this chapter. He was always in demand as a public speaker on topics as far ranging as 'Women Saints, East and West,' which focused on the lives and contributions of Meera Bai, Yashodhara, Laila of Kashmir, Rabia of Basra, St. Theresa of Spain and St Bridgit of Ireland, the lives and philosophies of Ramakrishna Paramhansa and Swami Vivekananda, Gautma Buddha and Mahatma Gandhi, to such topics as 'The Five Most Abused Words in the World.' These were God, Democracy, Communism, Freedom and Religion. Many of Patel's early speeches now survive only in fragments, in school annuals or tattered cyclostyled sheets in the possession of retired school teachers. This surviving fragment from a speech he gave on Mahatma Gandhi in 1958 gives a hint of the tenor of his thinking. Why was Gandhi such a revered figure not only in India but in the entire world? What was the source of his strength, the magnet within him that pulled people to him? That seems to be the question he is trying to understand. The answer, Patel suggested, lay in Gandhi's 'dominating passion for truth.' 'That truth led him to confess publicly whenever he thought he had made a mistake. That led him to fight evil and untruth wherever he found them regardless of the consequences. That truth made the service of the poor and dispossessed the passion of his life for where there is inequality, and discrimination and suppression, there is injustice, and evil and untruth.' ${ }^{14}$

In another talk, Patel reflected on the moral and social dilemmas facing mankind in mid-20th century. Man was out to subjugate everything he could lay his hands on. 'He has already mastered the air and conquered the skies. He has made ether his messenger boy. He has turned silver bromide and celluloid into the greatest entertainer of mankind. He has manufactured thunderbolts and lightning which make him the envy of the gods. He has invented new methods of surgery and found new drugs to cure disease which would have passed as miracles in the days of Christ. He has achieved all this and more.' And yet, despite all this progress, 'the common man enjoys more comfort but less happiness than before.' Soldiers were much better-fed and looked after on the battlefield 'but we have failed to abolish the battlefield and the havoc, misery and degradation it entails. We still rain bombs on women and children in the name of peace.' The Second World War had been fought to preserve the peace, to free the world of fear and oppression. 'All that mankind has got so far from the Second World War is the fear of the atom bomb and the loss of peace and individual liberty. Those 
who fought for survival not only lost peace with their enemies, they also lost peace among themselves.' And all the while, the modes of warfare are becoming more brutal and ruthless than ever. "The fear of war has enslaved the people of even free countries to the chains of bureaucracies, and individual freedom has become only a dream. The individual has become the slave of the herd and state everywhere.' $^{15}$

Patel read widely on a variety of topics, at the breakfast table, in the car while travelling, whenever he had a spare moment. ${ }^{16}$ Jai Ram Reddy recalls him as a 'voracious reader.' And he wrote as well. Here is one small piece he wrote on 'Enjoying Things': A capacity for enjoyment is the most valuable gift that anyone can possess. Freda Lingstrom found that one of the chief delights in a wholesale enjoyment of being alive was being with other people. Even if they were total strangers, observation transformed them from passing shadows into real people. She often entertained herself when travelling in a train or bus by studying the feet of the passengers and trying to guess what kind of faces belonged to the feet. 'The feet are passively, innocently, eloquent,' she wrote, 'some turned in, some turned out, some down at heel with wrinkled socks. Some wear pointed shoes, some snub-nosed ones with neat or untidy laces, or a button which makes you hold your breath because it only hangs by a thread. Most feet are absolute portraits of their owners.' 'For me,' said Paul Dehn, the poet and critic, 'cooking a meal is like writing an article which is why I enjoy doing it. The creative business of getting words to paper and a meal on to the table are not very different. An article must have an appetising introduction, a strong middle section, and a graceful end. So must a good dinner. Style was also important, and favoured regional unity by keeping meals all-French, all-Italian, all-American and so on.' For Christopher Fry, the playwright, the unexpected and the accidental had a particular charm. 'When something is unexpected as well as enjoyable, it calls up a special response in us, as though we had gained one more small foothold in a confusing world.' The unforeseen might consist of a special melody, the sight of a snake in his actual state, a harmless slow worm coiled in the middle of the drawing room carpet, or a herd of cows on the seashore instead of in the meadows. He and his wife had received an accidental wedding present of a remarkable kind when they discovered that the old mill house in which they had made their first home, on the chance recommendation of a house agent, lay in the very valley which they had passed as an engaged couple and thought an ideal place to live.

15 Pacific Review, 6 January 1951.

16 Patel's personal library, minus many volumes that were borrowed but never returned, is in the Patel family home at Nadi. There are books there by Vladimir Nabakov, Bertold Brecht, Andre Maurois, S. Radhakrishnan, John Osborne, Maxim Gorky, Berdyaev Nicolas, Herbert Marcuse, Lin Yutang, John Strachey, Nirad Chaudhary, Harold Laski, John Ruskin, VS. Naipaul, H.G. Wells, all the great English novelists of the 19th century, the major writings of Indian nationalist leaders, memoirs of Cordell Hull, Winston Churchill and other such notable figures of modern history, books on Fijian history and politics and many, many more. 
Patel urged people to read for the sake of sheer intellectual pleasure. He quoted Joyce Carey's advice in a speech in December 1955: 'The discovery of reading as a pleasure can change a life. For it is the keenest, the cheapest, the most lasting of pleasures, and it needs no co-operation. The most lonely people can have company in a book, the most God-forsaken soul on earth can find some peace there. And no one can know the reach of his imagination until he reads. ${ }^{17}$ He often despaired of what he saw around him, a dreadful waste of talent and opportunity. There was so much potential, so little of it realised:

We do not possess any works of art or architecture. There are no stately homes, or beautifully laid out farmsteads or orchards. With so much natural beauty, man makes little attempt to paint or carve beautiful pictures or write inspired poetry or compose enchanting music. With abundance of stones everywhere, there is no sculpture or architecture of any sort. Fiji has so far made no start in the field of literature. Even legends, folklore or folksongs of poetic or historic merit which are usually found among primitive peoples are conspicuous by their absence. Nothing that is made or built in Fiji has got an appearance of permanence. People live and work as if they were mere sojourners in Fiji. Even the Fijians do not create or make anything which they can proudly pass on to their descendants. Fiji has so far not produced a single man of high intellectual attainment or scholarship. Education is given and undertaken solely for the purpose of white collar jobs. We are therefore a Colony of mental and spiritual pygmies who neither live abundantly nor in abundance. This is Fiji after seventy years of British rule. It is true that government cannot make people. But it can create conditions under which indigenous civilization and cultures of all communities can grow and flourish. ${ }^{18}$

Patel urged the government to set up public libraries throughout Fiji 'to attract the youth and wean them away from the perils that threaten them.' These perils included 'increasing larrikinism, recklessness, drink and other evils.' Concerted, continuous effort was needed. "There is a clear acknowledgement all over the world that we should not teach people to read and then leave them without literature. For they would then relapse into a dreary and ultimately dangerous state of half-education, in which they would be easily satisfied by crude semipictorial approximations of the strip cartoon and by the abundant supply of degenerate literature which destroys, rather than promotes, a capacity to face the problems of the world with skill and courage.' Many people, including S.B. Patel, thought the idea of a library service premature. ${ }^{19}$ A.D. Patel disagreed.

17 Pacific Review, 9 December 1955.

18 Pacific Review, 18 August 1959.

19 Pacific Review, 29 July 1955. 
'We have to make a start. We must provide opportunities for people for good reading, and create good taste. We must create good libraries to create the desire. It may appear as putting the cart before the horse. But it is not really so. We do not wait for hunger before we begin to cook.' But this plea fell on infertile ground. The government demurred, and the politicians did not demand action. A colony-wide library system would begin a decade later when Patel became the Member of Social Services in $1964 .^{20}$

The Ramakrishna Mission, established in Fiji on 26 September 1952, provided the institutional base for Patel and the Swami. Rudrananda was its president and Patel its most prominent member. ${ }^{21}$ Patel was a devoted follower of the Ramakrishna Mission. This is what he said of its founder in 1959: 'Sri Ramakrishna is like a lighthouse in the modern world. He has taught us the harmony of religions. Whatever maybe the source of rivers, he said, all join the same sea. All religions, wherever they flourish, lead to the same God. This is the essence of Ramakrishna's teaching. ${ }^{22}$ Education was a high priority of the Mission, and it was in this field that the two men worked very closely, both realising the vital importance of education to the future of the Indian community. By the late 1940s, there were only a handful of schools established specifically for the Indian community. These included Natabua (1919), Samabula (1929), Andrews, Votualevu and Vatuwaqa (1930), Karavi and Wainikoro (1931). Of them only Natabua since 1930 and Dudley since 1945 had offered secondary education for Indian children. The Sri Vivekananda High (SVH) which the Mission founded was only the second (and the first privately run) Indian secondary school in the entire colony. It is one of Patel's unsung contributions to the education of the Indian community in Fiji. Patel, the long-time principal M.R. Balaganapathi recalled, was the 'Father of our School,' who had used his influence, contacts and even his own money to advance the school's cause. This assessment is true because Patel believed passionately in the value of education. Throughout his life, he urged greater government assistance to schools, for expansion of schooling at all levels. Wrote Patel in 1954:

First and foremost must come the recognition and the realisation that education is not a luxury in colonial areas, but that it is as much a necessity as in free countries. It is an amenity for which every citizen

\footnotetext{
20 Patel was appointed to the Library Enquiry Committee in Sept. 1957, chaired by the Director of Education, and including R.A. Derrick, L.D. McOwan, C.H. Miller, Semesa Sikivou, Udayvir Singh, J. Hackett, and A.L. Parke.

21 Others included Sadhu Kuppuswamy, Appaswami Pillay, Jagnath Naidu, Munswamy Reddy, Rangaswami Naidu, H.M. Lodhia, Sundarji Kalidas.

22 Pacific Review, 26 March 1959.
} 
has a right. It is a social service which should be the first charge on the finances of a country. And in advanced countries it is not uncommon for the state to spend as much as 25 per cent of their revenue on education. ${ }^{23}$

The SVH opened at Nadi on 6 March 1949, initially under the management of Sangam but transferred to the Ramakrishna Mission in 1952. Getting the school started was not easy, just as registering the Sangam as a charitable organisation in the 1930s had been difficult. The main obstacle was the government's opposition to the idea of a private body, the Ramakrishna Mission, with no previous experience in the field of education in the colony, running a secondary school. The Education Department raised its usual concerns about staffing, curriculum, and examination. Where will the teachers come from? Who will pay their salary? What kinds of subjects will be taught in the school? The cost and maintenance of buildings and the infrastructure required to keep the school going? The government feared that the school might become a charge on public revenue at a time when it was already spending large sums of money on the expansion of primary education. There was another, unspoken, concern: that of losing control over educational developments in the colony, and of being pressured to provide jobs for graduating secondary school students. While he was still a member of the Legislative Council, Patel had a series of discussions with the Education Department officials to allay their fears and to urge them to take a more progressive view of the SVH project. They were reluctant.

Nevertheless, Patel persisted. As Principal Balaganapathi recalled, 'the tireless triumvirate ('Sadhu-Swami-Patel') with their band of loyal workers stood firm and opened our School.' Thereafter, it became easier for other such private bodies to operate secondary schools in the colony. The founding of that school was one of the most important events in the history of the Fiji Indian community in the post-war years. Before then, the number of secondary schools which catered to the educational needs of children of poor Indian parents was limited. As mentioned, the Natabua Secondary was the only high school in western Viti Levu which Indian children could attend. In southern Viti Levu, the Marist Brothers High School in Suva took a limited number of Indian students. SVH was the first secondary school in Fiji started by Indian people for the education of their children. This school was to Indian education what the Queen Victoria School was to Fijians and the Suva Grammar to Europeans.

Most of the school's early teachers came from India, with the assistance of the Ramakrishna Mission. The Mission also provided books and other assistance in getting the school started. Many students who graduated from S.V.H. went on for their tertiary education to India, sometimes on Indian government scholarships. Many went to colleges and universities in South India in such 
places as Kerala, Madras, Coimbatore, Karaikkudi, Andhara, Madurai, while a few went further north to Baroda, Bombay and Delhi. Swamiji's connections and the Mission's practical assistance were instrumental in securing places for the school's students. Other students, after completing their University Entrance at the Natabua Secondary School, went on to universities in Australia and New Zealand, especially the latter. The graduates of SVH would constitute the who's who of the Fiji Indian community, including two future leaders, Jai Ram Reddy and Mahendra Chaudhry and scores of lawyers, doctors, chemists, businessmen, teachers, public servants, academics. In time, the SVH established itself as one of the premier secondary schools of Fiji.

Each year, a public figure was invited to give the convocation address at the school. ${ }^{24}$ On 17 September 1954 Sir Julian Huxley opened the science department of the school and spoke on 'Science in the Modern World.' In June 1957, historian K.L. Gillion spoke on 'Writing the History of Indians in Fiji.' In May 1956, A.D. Patel asked 'Is there God?' J.G. Rodger, the Director of Education in Fiji, discussed 'The Aim of Education' in 1955, and C. Harvey, the Director of Agriculture, 'Wise Use of Land' in 1956. In 1958, R.O. Campbell, District Officer Nadi gave 'A Word Of Advice' and the Public Relations Officer Jack Hackett spoke on 'The Importance of Racial Harmony.' In March 1959, John Daniels of the CSR, spoke on 'Sri Ramakrishna and Family Planning,' and Ravuama Vunivalu addressed the school on 'Vivekananda: His Message to the Youth.' There were few schools, government or mission, which could boast such a distinguished gallery of convocation speakers. The school's older students still remember these occasions with pride.

All the normal academic subjects were taught at SVH, including English, Hindi, Arithmetic, Algebra, Geometry, Health Science, Geography, History and General Science. Its students sat for the Cambridge Junior and Senior examinations. Scholastic learning formed the bedrock of the school's curriculum. But there was an added dimension to SVH education. The school also inculcated pride in one's culture and self-respect. 'The so-called and so-treated downtrodden man was lifted up and made to feel a MAN with self-respect.' 'Ramaswamis and Munswamis' were no more a laughing matter,' recalled one of its teachers. Each day began with a congregational prayer and students were taught to respect all religions while remaining true to their own faith. All major religious festivals or occasions were celebrated, including Ram Naumi, Krishna Janmasthmi, BakrId, Saraswati Puja, Diwali, Easter as well as the birthdays of Ramakrishna and Swami Vivekananda. Equality of all and brotherhood among men formed the core of the moral education imparted by the school. Patel expressed his hope for the school in 1952: 'Over and above the intellectual training they get, the spirit of comradeship and the unity of outlook that is implanted in the children 
of diverse races, who have come to rub shoulders in the classroom and outside, will certainly help in the gradual growth of a society in Fiji with emphasis on common outlook, unmindful of the difference of race, religion or colour. ${ }^{25}$

While running the SVH, the Mission also involved itself in programs of adult education in the rural areas. Instruction in Malayalam, Telugu and Tamil was available to those who wanted it. A Mission Library was opened in Nadi, with a branch at Lautoka, inspiring the establishment of the Western Regional Library at Lautoka which was opened by A.D. Patel on 20 November 1964. The Mission together with Sangam also ran a mobile library service suitably named the 'Gynana Ratham,' the Chariot of Knowledge. Bhajan mandalis (prayer songs) and temples were founded, singing competitions organised and essay competitions run. The topic of the 1959 essay competition was: 'What I learn from the Story of Rama.' In contrast, the Education Department ran colony-wide competitions on such topics as 'The Importance of the Cession Day to Fiji.' The Colonial Sugar Refining Company, for its part, ran its school competitions on the contribution it had made to the development of modern Fiji.

In 1956, Patel urged the South Pacific Commission to establish a University College of the South Pacific. He envisaged it as a joint project of the United Kingdom, the Netherlands, New Zealand, Australia and the United States, to be initially affiliated with a metropolitan university - as such institutions in the Caribbean and parts of Africa were - but to become fully autonomous in due course 'for the benefit of all the territories here.' Patel acknowledged the difficulties involved in starting such a big project, including finance, infrastructure, staffing and curriculum, but these were matters of detail and not issues of principle. Much was to be gained by having a university in the South Pacific. Perhaps most important, it would create a 'wise and competent indigenous leadership, essential for the solution of the problems facing the territories and the general advancement of their own communities. ${ }^{26}$ Not surprisingly, no one listened. But Patel persisted. On a visit to India in 1962, he discussed the proposal for a university in Fiji with the officials of the Government of India, which was prepared to pay half the cost of establishing such an institution, and offered the services of a Registrar. This initiative might have borne fruit but for the fact that by the mid-1960s the idea of a regional university was already being mooted in official circles, the result of which was the establishment of the University of the South Pacific in Suva in 1968, more than a decade after Patel had mooted the idea himself.

The provision of adequate educational facilities for the Indian community was an issue close to Patel's (and Swamiji's) heart. But the Indian community had

25 Pacific Review, 1 January 1954

26 Pacific Review, 26 April 1956. 
other pressing needs as well, among the most important being the need for a newspaper. They had first realised this need during the 1943 strike when, without a newspaper of their own, they had to communicate to the growers on crudely printed cyclostyled sheets. There was the Fiji Samachar, but it had been banned for the duration of the war for its alleged disloyal coverage of news; and it was under the influence of Vishnu Deo. What was needed were firstrate English and Hindi weeklies, which would promote greater appreciation of Indian culture and counteract the biases of the Fiji Times. So the Pacific Review was launched in 1949, and the Hindi weekly Jagriti in 1951. Both these papers were printed by the Sarada Sangam Press which had been established in 1948. ${ }^{27}$

The Pacific Review was a remarkable paper, the first of its kind in the Pacific Islands to have a regional focus, though as time went on, it became a much more Fiji-focused, and a sympathetic friend of the National Federation Party. ${ }^{28}$ The inaugural issue of the newspaper, dated 8 January 1949, began with three quotations:

Justice and Truth make men free, injustice and error enslave them (Mary Baker Eddy)

Courage is that virtue which champions the cause of right (Cicero)

There is need for realisation of the existing fact of universal brotherhood of man (Dr T.Z. Koo).

A.D. Patel wrote the introduction to the inaugural issue. 'The path of starting a new paper is by no means strewn with roses,' Patel said, but they had made a start. The aim of the Pacific Review, he went on, was to allow people in the dependent territories of the South Pacific the opportunity of 'free and unfettered expression,' and to 'break down the narrow walls of isolation and make mutual contact and our contact with the outside world easy and beneficial.' The people of the South Pacific, Patel wrote, 'have very little voice in the shaping of their destinies'. They needed a suitable medium to represent their concerns. This was made all the more necessary given the geographical location of the islands. 'Ours is a world of tiny islands flung considerable distances apart from one another with poor communication and no contact. While this sort of isolated existence may have been a splendid thing in the past, in the present world it provides no guarantee for security or peace'. The first issue carried articles on Papua New Guinea, Samoa, Nauru, the Cook Islands, and the Chinese in Samoa. Patel then explained the underlying philosophy of the paper:

27 Establishing the press with Sangam money annoyed some of the Sangam people, and hence the trouble discussed earlier in the chapter.

28 On the inaugural management board of the newspaper were A.D. Patel, H.M. Lodhia, G.B. Hari, M. Narsey, C.J. Patel, CM. Gopalan, and S.B. Patel. 
We believe in freedom, justice and human dignity as the birthright of mankind. It shall therefore be our duty to fight and resist imperialism, exploitary colonialism, racialism and such other natural enemies of the fundamental rights of human beings. It will be our duty to preserve and promote mutual understanding and respect for the rights of the individual and to spread the light of knowledge and culture. We seek your support and co-operation in this noble cause.

The launching of the Pacific Review together with its sister vernacular papers in Telugu and Hindi was a farsighted move of great social, political and cultural significance to the Indian community at many levels. With a paper of their own, the Indians, and others not with the European establishment, now had an avenue to express their views and to communicate directly with each other, which they did not have previously. Those letters to the editor and other articles which the Fiji Times refused to publish for political or ideological reasons, found their way into the Pacific Review. Ratu Mara published an article on 'Freedom and Development in Fiji, ${ }^{\prime 2}$ and Josefata Kamikamica and Ravuama Vunivalu engaged in long debates in the pages of the weekly journal. Timoci Tuivaga, the future Chief Justice of Fiji, wrote a letter to the paper in May 1949 lamenting the paucity of Fijian professionals and urging the need to pay more attention to Fijian education. ${ }^{30}$ There were letters from Fijians dissatisfied with the chiefly system, with the Fijian establishment or with the pace of political change in the colony. And there were numerous letters and contributions from Indians telling the government what to do or where to go. They make wonderful, invigorating reading. The reading public and the outside world now heard a plurality of voices on subjects of importance to the country, and not just the official voice that filtered through the Fiji Times or the Fiji Broadcasting Commission or the government's own various propaganda organs.

Just one example of this will suffice. In the 1950s, the United States carried out a series of devastating nuclear tests in the Trust Territories of the Pacific Islands, then under its UN-supervised jurisdiction. There was little mention of this in the Fiji Times or other official sources. Not so with the Pacific Review. Patel wrote several articles on the subject. In March, 1956, he said that the 'statement of using nuclear weapons in a future war is more of a political stunt than reality. Evidently, politics in the United States is as bad as the weather in the South Seas. Both are unpredictable.' It was foolhardy to think that one could win a nuclear war; no one would 'escape ruin and devastation in a future world war.' The following month, he criticised the United States for carrying out atmospheric tests: 'In the name of humanity, stop the nuclear tests. Saner voices all over the world have proclaimed that the nuclear arms race cannot

29 Pacific Review, 12 November 1949.

30 Pacific Review, 7 May 1949. 
lead to an enduring peace and that it must be stopped if humanity is to be saved from suicide.' Commenting on America's intransigence, Patel said: 'Riding roughshod over humanity and legality reminds us of dictators like Hitler and Mussolini. What resulted from them and their policies the world only knows too well.' It would be hard to find a stronger and more explicit condemnation of the American nuclear tests in any newspaper even in the metropolitan world at the time.

In addition, the Pacific Review, under Patel's editorial guidance, published articles on important philosophical and cultural issues by the leading authors of the day. Whether the journal's readers actually understood their contents is another matter, but both Patel and Swamiji were anxious to expose the people to great issues and ideas. Thus Bertrand Russell's article, 'Modern Mastery of Nature' appeared in an issue in 1951, along with Lord Denning's on 'The Independence of the Jury,' Girin Mukherji's on 'Buddha: The Prince of Peace,' Cambridge historian Percival Spear's 'Independence in the Modern World/ along with scholarly articles on the lives of Albert Einstein, Aboriginal artist Albert Namatjira, Swami Vivekananda and many others. In effect, the Pacific Review became an instrument for cultural and intellectual renaissance.

The newspaper fulfilled another function. It carried extensive news of political and cultural developments in the Indian subcontinent. The Fiji Times' coverage of the subcontinent's affairs was meagre and by and large dismissively critical. It reported borrowed items from western news sources that accentuated the negative: reports of communal strife, natural calamities, poverty, social tensions. From its pages, India appeared a place where nothing much good ever seemed to happen. The Pacific Review went in the other direction, highlighting the subcontinent's cultural and artistic achievements, progress in science and industry and India's role in international politics. Thus while the Fiji Times might publish an article on Hindu-Muslim conflict, the Pacific Review published, in 1955, an article which reported a speech of an Indian leader: 'We have today in India even after partition, nearly 40 million Muslims. Islam has affected not a little the language, literature, music and other fine arts - in fact every department of life in India.' Fostering pride among Fiji Indians in their ancestral culture formed an important cornerstone in Patel's and Swamiji's agenda.

Soon after its inception, the Pacific Review began publishing a Fijian version of itself, the Vakalelewa ni Pasifika. The Fijian paper published translations from the Pacific Review, but it also included its own views on issues and events of particular interest to the Fijian community. The paper enabled Indian leaders to bypass the government controlled channels of communication with the Fijian people, and establish direct contact with them. It was a part of Patel's oftrepeated agenda to break down barriers between the two principal communities in Fiji. If only the two communities could understand each other, the problems 
of Fiji would be solved, Patel used to say. Political communication apart, the newspaper also carried extensive items on Indian culture and history directly to the Fijian people. So the readers of the newspaper encountered translations from the great Hindu epics the Ramayana and the Mahabharta, life histories of Indian sages, poets and artists, the philosophy of Mahatma Gandhi, and the political achievements of Jawaharlal Nehru. Poems on these leaders appeared in Fijian. In short, the $V P$ became a medium of public cross-cultural education, the first and so far the only experiment of its kind in Fiji's media history.

The newspaper also raised issues regarding human rights and political developments in Fiji. Patel wrote many of the paper's major editorials that touched on political and philosophical issues, particularly in the 1950s. In an editorial in January 1949, Patel castigated the United Kingdom for its colonial policies:

Time and again British statesmen in England have reiterated that the ultimate goal of British rule in the Crown colonies is self-government for the territories concerned. If that is really the goal, the least the British government can immediately do is to stop ruling these territories for the benefit of Great Britain and make the interests and welfare of the colonies the supreme objects of their rule. ${ }^{31}$

That was being idealistic. But Patel went on:

Fiji earns quite a substantial amount of dollars every year and it is only right and just that she should be free to make use of her dollars for her own needs. At present, Fiji is made to earn dollars for the benefit of Great Britain. Fiji can sell her sugar and copra to other countries at considerably higher prices than what the British Government gives her. It is high time that the British government stop treating Fiji as a closed shop of Great Britain and grant the people of Fiji fiscal and commercial autonomy.

That was a fantastic demand in the circumstances, but Patel was not one to be deterred by obstacles.

The colonial government itself did not escape Patel's censure for its unprogressive social and educational policies and for its constant 'emphasis on differences of race and culture' between the communities, 'ensuring that there was as little contact between the different sections of the population. ${ }^{32}$ The colonial government should encourage a common outlook among all its citizens. Indians were born in Fiji, but they had no right to call themselves Fijians. 'If Europeans settled in

31 Pacific Review, 15 January 1949.

32 Pacific Review, 2 July 1959. 
New Zealand and Australia can call themselves New Zealanders and Australians, if the European citizens of the USA can call themselves Americans, why on earth can Indian, European and Chinese citizens of Fiji not call themselves Fijians?'33 A decade later Patel would move that the indigenous Fijians should be called taukei and everyone should be called Fijian. Patel also criticised the colonial government for its handling of the land issue. A particularly sore point was the reservation of Fijian land. The Native Lands Ordinance of 1940 had provided that, in return for agreeing to let the NLTB lease their lands on their behalf, the government would ensure that sufficient lands would be put in reserve for exclusive Fijian use. It was intended that the work of reserving land for Fijians would be completed within ten years. Instead, it dragged on for nearly twenty years, causing much hardship all around, particularly among the displaced Indian tenants who had to find somewhere else to settle. Patel did not quarrel with the reserve policy itself, but raised a number of related concerns.

Among them were compensation and the resettlement of the evictees. ${ }^{34}$ The Native Lands Trust Board's position was outlined by its secretary G.J.T. Hansen in a memorandum published on 18 November 1949. The Board would allow a tenant, who had been given the notice of eviction, in accordance with the reserve policy, to harvest all his standing crops planted before the notice of nonrenewal, and to remain on the land until the Board made the final decision after consulting with the Resettlement Committee regarding an alternative site for the evictee. The NLTB would do all it could to assist with resettlement, provided that this did not conflict with its primary objective of protecting the interests of the Fijian people; but it made it clear that 'the question of rehabilitation of dispossessed farmers is not a matter for the Board.' Finally, and perhaps most controversially, the NLTB said that because 'past methods of farming on leased native lands have not led to any permanent improvements in such lands,' it would 'not be prepared to consider the question of compensation for improvements to such lands.' That was just like the Native Lands Trust Board, Patel said, for "who else would put forward such an excuse to confiscate tenant's improvements." He continued: "If the Board really believes the correctness of its opinion it would have certainly declared without beating around the bush that it was willing to pay for permanent improvements, if any, in the event of the non-renewal of the lease. Nobody then could have questioned the fair mindedness on the part of the Board'.

But it was patently untrue that the tenants had not made any permanent improvements on their leases, Patel argued. Even first class lands were acquired originally by payment of quite heavy premia to the native owners and then brought under cultivation by uprooting and clearing thick jungles of guava,

33 Pacific Review, 2 July 1959.

34 See Pacific Review, 3 and 17 September, 15 October and 26 November 1949. 
vai and other bushes hard and expensive to eradicate. In the first few years of their tenancy, the farmers struggled hard to make both ends meet. It was years of intensive cultivation and heavy manuring with coral sand, chemical and green manures which created some of the first class lands the farmers now' cultivated. Besides building up the fertility of the land, the tenants had planted coconut, mango, tamarind, orange, mandarin, jack fruit and other such crops which would yield rich harvests in the future. In many areas they had borne heavy costs building tramlines to take cane to the main line and from there to the mills. They had also been contributing substantial amounts annually to the Price Stabilisation Fund, the benefit of which would be enjoyed by the dispossessing landlords.' Was this the kind of 'past methods' of farming the Board had in mind? 'If the Board does not like the native lands as they are at present would they like the tenants, before they hand over the lands, to exhaust all improvements, cut down or dig out all valuable trees and turn into a veritable bush as it was when originally leased? Expropriating landlordism never runs short of excuses to swallow up what rightfully belongs to its tenants. But the excuse put forward by the Native Lands Trust Board is unique. It condemns its own creator.'

Where was justice, Patel asked, when the Fijian landlords were not only allowed to take their lands back, but also confiscate the improvements made by the Indian tenants? The landowners, Patel continued, should be duty-bound to pay the full value of the un-exhausted improvements. The government itself was morally bound to resettle the dispossessed farmers and help them with loans to get started. Why? 'The dispossessed farmer will not be allowed to mortgage his lease and as there will be no improvements on the lands which he can pledge, he will be thrown on the rapacity of usurious money lenders.' 'This procrastination on the part of the Government,' Patel said, 'has created deep resentment amongst the farmers.'

For its part, the government rejected the charge of procrastination. In mid1949, it had created a Resettlement Committee in the western division, chaired by the District Commissioner Western and consisting of the District Engineer Lautoka C.L. Langdale, C.E. Whitehead, Roko Tui Nadroga and Navosa, E.A. Potts and T.R. Sharma. The committee was asked to assist displaced tenants find accommodation outside the reserves and recommend to the Central Resettlement Committee lands which might be available for them. On paper, the government's proposals looked attractive, but again, there were questions. How exactly was the committee going to help the displaced tenants, Patel asked? 'It is well known that none of the members of the Committee has the means, authority or power to procure resettlement of the displaced tenants even if they had the best intentions of being helpful to the unfortunate tenants.' Would they intercede on their behalf for compensation for the improvements left behind, and seek 
out new leases for them on suitable but unoccupied land, or were they going to help provide funds to enable the displaced farmer start afresh? In short, the Resettlement Committee was a futile exercise, for the government knew all along what the problems were, and yet neither it nor the Native Land Trust Board had made preparations to meet an emergency which should have been foreseen at least ten years before. Instead of persuading the Fijian owners of the Reserves to wait until the Government had made proper arrangements for the evicted tenants, it had put the cart before the horse by throwing the tenants out of their old homes before finding them new homes. He said, sarcastically: 'What the Government did not or could not provide in a decade the Committee is expected to produce like a conjurer out of his hat on the spot. Though we do not believe in magic, we wish it good luck.'

The reserves policy and the problems it created for the Indian tenants generated intense emotion in the Indian community. Those evicted had to start all over again, often without any assistance. Meanwhile, their formerly productive land often reverted to bush. The friction created by the reserves policy, together with the increase in the size of the Indian population surpassing the Fijians during the war, created widespread hostility among Europeans and other self-styled champions of the Fijian people. A. A. Ragg was among them. He continued his interminable correspondence with the Colonial Office, telling all of the inevitable Indian domination of Fiji and the eventual dispossession of the Fijian people in their own land. He recommended a program of deporting Indians from Fiji. His friend, A.W. Macmillan, a former Inspector of Indian schools in Fiji retired in Tauranga, New Zealand, recommended the malaria-infested Sepik River valley of the New Guinea Highlands as a suitable destination for Fiji Indians. R.W. Robson, the publisher of the Pacific Islands Monthly, pointed to Marquesas as a possible destination where, he suggested, the Indians might end up by 'clawing each other to death/ but at least Fiji would revert to being the paradise it once was and so richly deserved to become.

Most Indian leaders rejected this alarmist rhetoric. Responded Patel in 1952: 'Like the red rag to the bull, the Indian problem in Fiji seems to send some people into an excitement and rage which deprives them of the power of thinking. And obviously well-meaning friends, on whom the White Man's burden sits heavy indeed, are busy planning solutions to imaginary problems and tilting at windmills. ${ }^{35}$ Two years later, by which time the anti-Indian hysteria had still not abated, Patel wrote scathingly of people like Ragg and Robson. Whatever such people think, said Patel, 'the Fijians and Indians consider their persons and property as valuable as those of their European compatriots and under no 
circumstances are they going to offer their skulls to be broken, or their properties turned into bonfire by one another as a benefit performance for the delight of the diehard propagandists.'

Do these propagandists ever stop to realise that the arguments they use to incite the Fijians against the Indians are in the nature of a boomerang with the tendency to recoil on themselves? For instance, when they talk of 'land grabbers,' the Fijians very well know who have completely gobbled up half a million acres of the best Fijian lands for almost a song. They know who fooled their fathers into selling hundreds of acres of their very best lands in return for a box of matches, a bottle of liquor, a musket or a piece of cloth. If the Fijians have only second best lands left for their own use, they very well know who licked the cream off their milk. From this leftover of their ancestral inheritance they have reserved first rate land for their own use and rented out the surplus to the Indians through a board of trustees, of which the Governor himself is the president. When the propagandists talk of the exploitation of the Fijians' lands, the Fijians immediately think of the gold mines and all the gold taken out therefrom every year without payment of a single cent to the Fijian owners of the land. When they talk about the increase of the Indian population, their minds naturally turn to the great epidemic of measles which almost wiped out their numbers, and they also know who are responsible for it. When these propagandists try to run the Indians down in the eyes of the Fijians, they overlook the patent fact that they and their forebears were responsible for the introduction of Indians in this Colony. The government of the day only did what the European planters asked them to do. If the Indians are such a bad people as these diehards make them out, the guilt of introducing these people into Fiji lies squarely on the greedy shoulders of the European masters, who placed orders with the government for the importation of these labourers. In these days of fundamental rights of human beings the Fijian knows who denies him those rights and keeps him behind. ${ }^{36}$

Unfortunately for Patel, if Fijians knew these truths, they were not speaking out publicly. For the most part, they closed ranks behind their chiefs and the colonial establishment. To these Fijians, Patel posed a number of questions. Why, he asked, were Fijians lagging behind the other communities, 'condemned to a state of inferiority in their dealings with other races in the economic life of this Colony' when the literacy rate among them was almost 90 per cent, and when they were, by far, the biggest landlords in the colony? Why were there not more Fijian boat builders and sailors, dominating the inter-island communications network, when in precession days 'the Fijians were famous in these waters for their skill in building canoes which braved the high seas, as well as for their 
seamanship?' Why were the Fijians still living in grass huts, 'the building and repairs of which take up most of their working time, while others manage their lands and exploit its mineral and forest resources'?

These questions went to the heart of Fiji's (and the Fijian peoples') problem. For Ragg and others like him, the main cause of the problems facing the Fijian people was the visibly increasing Indian population. Control the birthrate, and all the other problems would take care of themselves. Many Fijians thought likewise. But for Patel, the root cause of the predicament facing the Fijian people lay elsewhere, in the minutely defined and stringently enforced Fijian regulations which had reduced the Fijian people 'to a perpetual state of infancy in their economic relations with the rest of their fellow citizens,' and 'chained them to a primitive way of life and to a social and political order which is anything but democratic.' These regulations, which were finally abolished in 1966, defined the limits of the Fijians social and material existence, the things they could and could not do without official approval. As Patel said, 'We cry hoarse over extolling the virtues of private enterprise and running down communism, but when it comes to the Fijians we side with the chiefs and sing praises of the Fijian brand of communism and exhort them to keep clinging to it in the name of tradition and custom.' If the Fijian people were to succeed, Patel argued, they had to be granted more freedom to participate in the economic life of the colony, especially the Fijian commoners.

There was an Indian problem in Fiji, Patel agreed, but with a difference. While the Indian people had contributed to the economic development of the country, they had not contributed to its cultural and artistic development. That was the Indian problem. The Indians had a rich cultural heritage, 'which places service above self, and things of the spirit above material things, which fosters a catholicity of outlook and a dynamic spirit of tolerance.' So the challenge before the Indian people was: 'How they can worthily contribute their stream of Indian culture to the cultural life of this great colony and the Pacific Isles.' Why, Patel asked on several occasions, should only the Europeans be regarded as the protectors of the Fijian interest, who had used their access to the Fijian people to divide the two races for their own interests? The welfare of the Fijian people was as much a concern of the Indian community, Patel argued, as it was of the Europeans and the colonial state. 


\title{
Chapter 7: Fire in the Cane Fields
}

The growers are neither slaves, servants nor serfs of the Company. As far as they are concerned, there is no going back to the pre-war conditions.

\begin{abstract}
A.D. Patel, 1960
A militant leader is a leader who stand for and insists upon fair play, who refuses to be a tool in the hands of the employer and who stands firm whatever the colonial vested interests say; The salvation of the working classes in this country will largely depend on the so-called militant and irresponsible leaders.
\end{abstract}

\section{A.D. Patel, 1963}

The lull of the 1950s came to a sudden, turbulent halt in December 1959, when the Wholesale and Retail General Workers Union, led by Apisai Tora and James Anthony, struck for better wages from the Shell Oil and Vacuum Oil companies. The strike and the ensuing violence against European-owned businesses in Suva shook the city to its foundations, questioning many of the assumptions that underpinned the colonial order. Fijians and Indo-Fijians joining hands against expatriate companies was a rare, and frightening, sight for the colonial authorities to witness, especially when they had done their best to create institutions and structures to keep the two main groups apart from each other. Inevitably perhaps, the strike strained race relations in a colony where race relations were never warm anyway. The strike failed because of the combined opposition of the colonial government and Fijian leaders who ordered their people not 'to bite the hand that feeds you.' ${ }^{1}$ Even so, it deeply influenced political thinking in influential circles in Fiji for the rest of the next decade.

On the other side of Viti Levu, the sugar industry was also in ferment. After seventeen years of relative peace, the Colonial Sugar Refining Company and Indo-Fijian kisan were once again locked into a stalemate, which spawned a devastating strike in 1960. That strike, too, failed, but its consequences and ramifications were perhaps more far reaching than the Suva strike, extending well beyond the narrow industrial arena. This strike, too, became tainted with issues of race, and infected political discourse at a particularly critical time in Fiji's history. However, both directly and indirectly, the strike and the events that followed helped to define a new political agenda, which accelerated the dismantling of colonialism in Fiji.

1 An account of the strike is in Report of the Commission of Inquiry into the Disturbances in Suva, December 1959 (Suva, Legislative Council Paper 10/60). See also Rutherford, 1984,73-86. The Fiji Times also had extensive coverage of the strike. 
The sugar strike catapulted A.D. Patel back into active public life. Patel was living in semi-retirement in Nadi with his young and growing family, devoting himself to social and charitable work, and to reading and writing. This peaceful life of leisure, however, was soon to become a thing of the past. When it became clear that the CSR was quietly preparing itself for a protracted fight with the farmers over a new contract, the farmers realised that they would need the best brains to represent them in the difficult negotiations that would follow. Patel's name was at the top of everyone's list. When approached, Patel demurred at first, still sensitive about his rejection at the polls in the 1950s; but James Madhavan, Siddiq Koya and Swami Rudrananda prevailed upon him to change his mind and become the growers' leader and chief counsel in the negotiations with the CSR. Patel agreed, Koya recalled, 'when I pleaded with him to use his God-given talents for the benefit of his people, and point[ed] out that God could not have given him all those talents for his own use [only].' ${ }^{2}$ We will follow Patel's role in the negotiations and the strike which followed their collapse, his representations before the Eve commission, and in the events that ensued.

Many issues were at stake in the dispute between the growers and the Company. But once again, as in 1943, the fundamental issue in contention was the distribution of the proceeds of the sugar industry. Patel viewed the industry as an equal partnership between growers and millers; one could not exist without the other. As equal business partners, he argued, cane growers had the right to be better informed about the financial affairs of the industry and encouraged to be more involved in its management. They should, furthermore, get a fair share of the proceeds as well, and promptly. Cane growing was an occupation like any other. 'We are the owners of the goods and it is we who are out to sell on the market. The very first thing in the commercial world is for the buyer to ask on what terms we are prepared to sell. It is for the other side to say whether the offer is acceptable or not and what adjustments they would like before they decide to accept.' ${ }^{3}$ Dialogue not dictation was what the farmers wanted from the Company. As the sugar industry was the backbone of the economy, Patel felt that the government should maintain a watchful eye over its affairs instead of sitting on the sidelines. For this purpose, he argued, the creation of an independent Sugar Board, comprising of the representatives of growers, millers and the government was a vital step forward.

The CSR could not disagree more with such thinking. It rejected the suggestion that it was a 'mere miller of cane produced by independent, self-supporting growers.' The growers, it said, 'were not equal partners with the millers, and

2 Koya's recollection is in the NFP Souvenir Convention Program, 10 July 1970.

3 This account of the strike is based principally on the following sources: transcripts of the Eve Commission hearings, Patel's own papers, newspaper accounts, especially in the Pacific Review, and the CSR archives in Canberra. I was given access to Company records on the understanding that I would respect the principle of confidentiality. For that reason, I have kept detailed references to the sources to a minimum. 
still less with the Company, nor is there any prospect in the future of them becoming so.' Any attempt in that direction would be fraught with disastrous consequences. "The Company has been aptly described as the father and mother of the industry in Fiji. This connotes a family relationship in which the parents' domination and discipline must be accepted until the children reach the adult stage and the Indians have not done so. The parents have to foster and supervise every step and, when necessary, apply a reasonable discipline.' The tension between these two positions, the demand for full and accountable partnership on the one hand and (token) participation mixed with the threat of punishment on the other, lay at the heart of the problem in the sugar industry.

The farmers were suspicious that the CSR had been making large (concealed) profits at their expense, while they themselves had faithfully observed the terms of the agreement. The Company, Patel said, 'had made certain unauthorised deductions, sold molasses to itself at a nominal price of $£ 1$ per ton and thereby paid a smaller price to the cane growers than what they were rightly entitled to under the contract.' Making matters worse, Patel argued on behalf of the farmers, the Company periodically delayed payments for the cane already harvested, which aggravated the problem of their indebtedness.

There was another bone of contention between the Company and the growers, Patel said. In 1958 and 1959, CSR had encouraged overproduction of cane, and got farmers to resort to better methods of controlling, cultivating and fertilising land with the assistance of soil scientists while 'knowing fully well that production and sale of sugar was limited by the Commonwealth and International Sugar Agreements.' Patel went on to observe that 'this was deliberately done to weaken the bargaining position of the growers in the negotiations for a new contract in I960.' He commented on the emergence of new lorry contractors, about 3,000 altogether, who had to make their own roads and deliver their cane to the Company by lorry transport at their own cost. This, Patel went on, meant that the Company 'obtained cane from the new contractors at a cheaper price and at the same time created a rival block of sugar cane growers with a view to use them if necessary against the growers who were already producing cane in the old areas.'

The CSR did not deny encouraging overproduction, but argued that the sugar industry was 'now facing a fundamentally different set of circumstances to those of the past ten years.' Sugar production had increased considerably in the 1950s to take advantage of flexible international sugar quotas. The area under cultivation had increased together with growers' income from the industry. Good weather and better yields had contributed their share to the expansion of sugar cultivation. But by the end of the 1950s, the era of expansion was over, the CSR felt. Fiji no longer had a rapidly expanding 'cake' to look forward to. All that the sugar industry could do was to argue how the cake should be shared 
between the growers, the millers and the employees. As the CSR put it, the 'greatest danger which the Company foresees is that the grower and employee will find it hard to realise that they cannot hope to progress over the next ten years as they have over the past.' The Company was right in its assessment of the growers' likely reaction. Anticipating trouble, it attempted to strengthen its negotiating position to weather any future industrial storm. To that end, in 1957 it re-valued its Fiji (but not its Australian) assets by $£ 7,134,849$, raising it to $£ 13,030,370$. The Company's general manager in Sydney was told that 'our main reason for acquiring this valuation is the ever present possibility that some situation could arise in Fiji which could lead to an investigation, or some form of arbitration, in which it could be necessary to produce information. ${ }^{4}$

In January 1959, the CSR circulated a new draft contract to the farmers. Its terms differed substantially from those of the 1950 contract, which Patel had helped negotiate and which was to expire in May 1960. In the first place, the new contract offered farmers a quota based on tonnage rather than acreage as had been the case in the past. The Company had increased its surplus sugar from 24,000 tons in 1958 to 110,000 tons in 1959, and it wanted to use this advantage to impose complete control on production. As the CSR put it, 'Production must be brought into line with the markets on the basis of reasonable stock levels. Excessive stocks create physical difficulties, and result in storage costs, double handling, double insurance, cyclone risks, deterioration and loss of quality which affects ultimate marketing.'

Furthermore, the Company altered the price scale of the old agreement to cover itself against future market fluctuations in the price of sugar. It had done so, it argued, because the prospects in the industry looked bleak. While the income from the sale of sugar and molasses had increased from £3.2 million in 1950 to $£ 11.4$ million in 1959, the income for 1960 had declined to about $£ 6$ million, and was expected to increase to about $£ 8$ million in 1961. As the Company put it, the 1950 agreement 'provided for too sharp a rate of increase in cane price with price of sugar and insufficient discount for cane yielding less sugar.' In the new contract, the Company took a sugar price of $£ 40$ per ton and a cane yield of 14 tons of sugar from one hundred tons of cane, as its central reference point. Under the new scale, growers would get only 59 per cent of the proceeds rather than the 62 per cent they got under the old agreement. In effect, the Company would pay more for higher yields and lower sugar prices, and less for lower yields and higher sugar prices.

The control of production on a tonnage basis and the new formula for sharing the proceeds were the main differences between the old and the proposed new contracts. But there were others as well. The new contract proposed stiffer

4 See Moynagh, Brown or White, 202. 
penalties for extraneous matter delivered with the cane, with half the penalties shared among all growers and the other half kept by the Company. The penalty for burnt cane was increased. Under the old agreement, the Company had been obliged to accept any cane cut before it issued notice to cut cane, but in the new contract, it reserved the right not to 'accept cane in the event of any interruption to work from strikes or from other causes beyond the reasonable control of the Company.'

In October 1959, the CSR issued a memorandum to the growers advising them that for the 1960 season, it would accept only 199,000 tons of cane harvested on a tonnage basis. The growers' leaders rejected this offer. Patel acknowledged that the Company had no legal liability to accept all of the $1960 \mathrm{crop}$, as the old agreement would have expired, but he argued that it had a moral responsibility to the growers to harvest all the crop. Suspicious of the Company's intentions, and finding many clauses in the new contract cumbersome, in parts even incomprehensible, Patel urged the different growers' associations to pool their resources and work together to negotiate the new contract. The result of this proposal was the formation of a Federation of Cane Growers Associations in May 1959 at Lautoka. ${ }^{5}$ The Federation committee consisted of all the main cane growers associations, including the Maha Sangh, the Kisan Sangh, the Vishal Sangh and the Vanualevu Farmers' Union.

On 18 November 1959, Patel sent a draft of an alternative memorandum of agreement to the Company, prepared by himself, S.M. Koya, J.P. Bayly and Vijay R. Singh. The Federation Committee proposed a ten year contract instead of the shorter term contract proposed by the Company. The growers wanted the right to plant any one of the varieties of cane approved by the Company itself, rather than a restricted number, arguing for flexibility within the overall framework. The price of cane payable should be determined by dividing 70 per cent of the total f.o.b. value of all sugar, molasses and other saleable by-products produced during the crushing season. The growers wanted 75 per cent of the price to be paid to them within thirty days of harvest, 15 per cent within the crushing season and ten per cent by the 30th of April following the end of the crushing season.

The CSR and the Federation Committee met to discuss the growers' proposal at Lautoka early in January 1960. At that meeting, the Company reiterated its point about being overstocked, and the need, therefore, to keep the 1960 production figures low. Counteracting, the Federation Committee suggested

5 Among those who helped found the Federation were Ajodhya Prasad, Abdul Gani, A.D. Patel, Bechu Prasad, K. Ramaswamy Pillay, Pandit Ram Narayan, K.S. Reddy, Ram Newaj, S.M. Koya, Shiv Datta, Baijnath Prasad, Vijay R. Singh, Girwar Prasad and James Madhavan. See Pacific Review 3 May 1959. According to some sources, the actual suggestion to form the Federation had come from Alipate Tataiya, a far-sighted farmer from Tavua. 
that to overcome the surplus problem, the growers should be advised not to plant any more cane during 1960. Patel: "As it is, the 1961 ratoon crop must be enough for the CSR Company to make up the quota, besides the surplus and the extended harvest of the 1960 crop in 1961. Thus with the whole crop of 1960 and the ratoon crop of 1961, the farmers of Fiji and the CSR Company in cooperation will be fulfilling Fiji's quota and obligation with little sacrifice.' The CSR naturally disagreed, and further negotiations were postponed. At their next meeting on 2-3 February, the CSR returned with further amendments to its original draft that, according to Patel 'were even worse from the growers' point of view.' Among other things, the Company wanted farmers every March to consult their overseers to find out how many tons of cane the Company would purchase from them the following year. According to Patel, this was designed 'to establish a permanent pool of surplus cane every year at the expense of the grower to enable the Company to draw from it in the event of an emergency such as the Suez crisis.'

With no prospects for an amicable dialogue in prospect, the meeting was postponed till 14 March. At this meeting, the CSR withdrew its offer of a ten year contract and instead offered one for two years. The future was simply too uncertain for it to make long-term commitments. Other conditions were added which gave the Company the discretion to compel growers to deliver their cane to the mill at their own cost by lorry contract, 'and if the farmer refuses to do so, the Company will be entitled to terminate his contract.' On the question of expeditious cane payment demanded by Patel, the CSR agreed but on the condition that growers pay interest on the amount the Company would have to borrow to fulfil its commitments. Patel was unmoved. As far as he was concerned, the growers were not liable to pay any interest under the existing agreement and would instead insist upon full and prompt payment. He told J.C. Potts, the CSR's General Manager in Fiji: 'We say that both under the existing contract and the practice followed thereunder for the last nine years, the Company is bound to make the final payment by the end of April. Payment is not conditional upon the Company receiving the proceeds of the sugar. The price of all sugar sold by the Company up to this date is known to the Company. As to the unsold sugar, the Company has to estimate the price as it has been doing in the past, and make the final payment immediately...We are definitely of the opinion that the Company is committing a breach of the contract in delaying the payment and is doing so to bring financial pressure on the farmers so that they may agree to sell their cane to the Company on its own terms. This is definitely unfair and illegal.'

There was no point in continuing further discussions, Patel said, unless the Company was willing to buy all the cane ready for harvest during the 1960 season and prepared to offer a better price and other terms than it had done. The CSR was equally adamant. In a letter to Patel on 6 May, it said the Company 
're-asserts that it is not prepared to offer a better price, or to make more than minor variations in other terms that have been presented already to the growers through your associations.' Negotiations had broken down. The CSR General Manager declared a deadlock and asked the Governor to appoint a commission of inquiry. When the Governor raised the issue of a commission of inquiry with Patel and other growers' leaders at Lautoka on 7 May, the offer was rejected.

A commission of inquiry would be a waste of time, Patel said. In the first place, since the commission would have no jurisdiction over the Company's head office in Sydney, it would necessarily have to rely on the good will of the Company to supply information to the commission or produce its books of account. The Company had offered to make these available to a chartered accountant, but that was of no help to the growers themselves who would be denied the opportunity to inspect it. The commission had no power to compel the Company to produce all the relevant information. Without this growers would be hindered in presenting their case. There was another point to consider, Patel said. 'The findings of the Commission even after the expenditure or all the money and time involved in such an enquiry, cannot be binding on either party. The parties will have to come to a negotiating table to settle a contract.' The growers had ample experience of such commissions in the past, Patel said. 'They know how the Company bamboozles such commissions to its own way and how abortive and expensive they turn out to be in the end. Such commissions go further and treat the farmers as if they belonged to a lesser species than the Europeans and go the extent of laying down the size of the farmer's family, what he and his wife and children should wear and eat and what they should not. Only their physical needs are taken into account. The commissions have only added insults to injury. The farmers belong socially to the middle class of Fiji - the same class to which the Company's officers and managers belong.'

Instead of a commission, Patel wanted a court of arbitration with binding powers to resolve the dispute, convinced that if all the facts in dispute were independently arbitrated, the farmers would get a better deal. But the CSR opposed the idea as being 'disastrous in both the immediate and the long term.' Faced with the Company's adamant position and official dithering, Patel said:

The time has now arrived for the parting of the ways. The growers must prepare to stand on their own two feet, establish their own cooperative mills and become the processors as well as producers of cane. They will have to emancipate themselves and this country from the economic 
bondage of such [a] ruthless monopoly. It can be done. It should be done. It must be done if the growers and their families want to live in security, peace and freedom.'

At a meeting on 9 June in Suva chaired by the Governor, the Federation Committee offered to sell a sufficient amount of cane to manufacture 199,000 tons of cane under the terms and conditions of the 1950-60 agreement. The Company demurred. It would consider this proposal only if the growers' representatives agreed to a commission of enquiry, which the Federation Committee refused. By then, the CSR began to realise that it was getting the upper hand in the strike, especially when the first visible signs of cracks began to appear among the growers' unions. Until then, all the growers' negotiations with the Company had been conducted by the Federation Committee. But suddenly, the Fijian Association revived a dormant Fijian cane growers' union, and formed two new ones in $\mathrm{Ba}$ and Sigatoka, to represent indigenous Fijians in the negotiations. About 5 per cent of the cane growers were indigenous Fijians. Among those behind this proposal was John Falvey, the legal advisor to the Fijian Affairs Board and a key figure in European and colonial politics in Fiji.

The crushing for the 1960 season was scheduled to start on 21 June, but no mills opened. About 1,400 mill workers were given a week's notice terminating their employment. As days and then weeks passed, feelings hardened on both sides. The Company said that all mills would close on 22 January 1961 even if all growers' quotas were not harvested by then. This was contrary to the practice under the old agreement which had obliged the Company to accept from each grower a fixed quota of cane. The farmers rejected the allocation of quota on a tonnage basis. For its part, the government criticised what it described as the recalcitrant attitude of the farmers, suspicious of their leaders' proposal to set up cooperative mills in Fiji. That was tantamount to the Indian community making a bid to take over the most important industry in the colony, which would 'lead to political strife and bitterness among different races in the Colony.' The farmers thought the government was the CSR's handmaiden. As A.D. Patel put it, the CSR was a 'strong monopoly, one solid front, a government over Government.'

On June 27, the Governor, with the advice of three unofficial members of the Executive Council, proposed a solution:

It is suggested that the Company might buy the 1960 crop up to quota level, at a price based on the price clause in the recently expired agreement, subject to adjustment of details already discussed, on the understanding that negotiations regarding the 1961 harvest shall start

6 Pacific Review, 16 June 1960. 
at once and that if no agreement is reached within a reasonable period of time Government will review the situation and take such steps as it may then consider necessary. ${ }^{7}$

The CSR accepted the proposal 'subject to adjustment of certain details.' What these adjustments were remained unexplained. The government's offer was carefully scrutinised by the growers association. On 1 July, A.D. Patel wrote to the Governor seeking clarification of points in his proposal. Would the 1960 crop be harvested by the Company on the basis of existing contract between the Company and the individual growers or on some other basis? Would other clauses of the expiring contract apply to the 1960 harvest? Did the words 'subject to details already discussed' mean that the CSR could bring other proposals outside the existing agreement? If no agreement was reached, who was to decide what a reasonable period of time would be? Did taking 'such steps' mean the possibility of a commission of enquiry and the obligation on the growers to appear before it? These were relevant questions in terms of what had transpired in the dispute up to that point, but the government thought the growers leaders were using delaying tactics, playing politics, arguing over petty details.

On 20 July, Patel and his colleagues met with the CSR officials over five days for last minute negotiations. Also present at the meeting were three newly formed Fijian growers associations. The Federation Committee was aware of increasing dissidence and impending disunity among its ranks, with some influential people, distrusting of Patel and his tactics, willing to compromise. The 'better half a loaf than none' syndrome. B.D. Lakshman, the sitting Legislative Council member for the Western division, was one of them and Vijay R. Singh another. The Federation Committee conceded the Company's demand for a share in the deductions for the burnt cane. It also agreed to share the liability for losses suffered through lightning strikes. But for the CSR this was not nearly enough. It knew that it had the growers on the run, and so pressed for more concessions. It stuck to its original demand that all mills close on 22nd January, whether or not the growers' quota was harvested, that the Company not be obliged to buy from each and every grower a fixed quota of cane, and that tonnage and not acreage be used as the basis of allocating quotas.

By now, the split in the ranks of the growers had come out in the open. On 24th of July, 1960, five of the original 19 members of the Federation Committee, led by J.P. Bayly, Ajodhya Prasad, D.S. Sharma, Shiunath and Vijay R. Singh, broke away and separately signed an agreement with the CSR for the purchase of the 1960 crops. Because that agreement became the cause of such intense debate and controversy in the Indian community in the 1960s, it is reproduced in full below:

7 CSR archives (1959 strike papers) in the Noel Butlin Archives, The Australian National University. 
A Vision for Change

24th of July Agreement

1. Arrangement made in connection with quotas, price and other matters are of an ad hoc nature and apply only to 1960 harvest. Neither party shall be deemed to have committed itself to any proposals or stipulation of the other party in respect of 1961 or any future crop.

2. The objective is to harvest sufficient cane to produce quota level production of 199,000 tons of sugar which on an appraisal made at the time of the preparation of the Company's annual report was expected to require about 80 per cent of the crop.

3. With the object of achieving equality of advantage to each grower it is agreed that one half of the area of standing cane on each farm will be harvested in the first round, each grower being entitled to designate the half area of standing crop he wishes to have harvested and defined on the ground by the gang committee and sirdar. In the second round the balance of the quantity of cane to be supplied will be on a tonnage basis related to the production of quota level sugar and the tonnage for each farm will be calculated in proportion to the tons already harvested in the first round.

4. If some grower has not had his allotted second round tonnage of cane harvested before the date of finishing of crushing the quantity short harvested shall be added to the individual grower's tonnage for 1961.

5. The burnt cane deduction of $1 / 6$ per ton is to be formed into a special fund to cover losses to the growers arising out of strikes mentioned below. If after meeting such losses, there is any surplus, such surplus is to be divided equally between the Company and the growers. Likewise if there is a deficit, the Company and the growers are to make up such deficit in equal shares. If there is a strike - i.e. a strike by mill employees without sufficient notice to enable the Company to give notice to cease harvesting and there is cane harvested and not crushed as the result of such strike, farmers suffering any loss are to be paid out of the special fund created by the deductions out of burnt cane-as above.

6. Payment for stand-over crops not fit for manufacture will be the first item for discussion in the negotiations for the 1961 quota.

7. In planning to achieve the objective of producing quota level sugar the Company states that the mills will not continue after 199,000 tons of sugar have been made or beyond 22 January at any mill, whichever is 
the sooner. If the mills start crushing immediately and there is no undue interruption and the mills have a full supply of fresh and clean cane it is expected that every grower's quota of cane will be harvested.

8. Except for the ad hoc arrangements stated above the conditions of the recently expired agreement for the purchase and sale of sugar cane shall obtain.

9. Both sides recognise the urgency of starting negotiations for the sale and purchase of future cane and consider it desirable to commence such negotiations now that an agreement is reached for the sale and purchase of the 1960 crops. The Company may fix the date for such negotiations after the start of the 1960 season.

The agreement was signed by J.C. Potts on behalf of the CSR, J.P. Bayly, president of the Kisan Sangh, Vijay R. Singh, president of the Labasa Kisan Sangh and by Isikeli Nadalo of the Nadroga Fijian Cane Growers Association, Maleli Dakui of the Ra Fijian Cane Growers Association and Ratu Marika Latianara of the Ba Fijian Growers Association. The Fijian cane leaders signed the agreement, N.S. Chalmers, one time president of the Kisan Sangh, recalled, because John Falvey and Ratu Mara had advised them to do so and to 'forget altogether about Patel. ${ }^{8}$

The agreement was widely publicised through the radio, newspapers and the CSR publicity machine. Its terms were discussed at mass rallies of farmers throughout the cane growing areas, causing great bitterness and division among them. Singh, who had master-minded the negotiations which led to the agreement, explained his position. He himself did not particularly like the terms of the agreement, just as he did not like paying taxes or the school fees of his children. But that agreement was the best that could be achieved in the circumstances. The Company was not willing to enter into a ten year contract with the growers, so a temporary arrangement was the best way out of a difficult impasse. How could the farmers negotiate from a position of starvation and bankruptcy which would certainly result from the course of action pursued by Patel, Singh asked? The CSR was not the evil giant its critics had made it out to be, Singh argued, noting the mutuality of interest, the partnership, between the millers and the growers. Perhaps its one major 'radical defect' was its 'public relations' which engendered distrust among the growers. ${ }^{9}$ By this he meant the Company's socially exclusive policies. Its senior officers were not permitted to mix with their local junior counterparts. They lived in separate, even segregated, neighbourhoods, aloof and apart.

8 Pacific Review, 17 November 1960.

9 See his contribution to the Legislative Council Debate of 30 September 1960. 
For Patel, the problem between the kisan and the Company was more deeprooted, more structural than cosmetic. There was a fundamental clash of interest between the two groups, he argued. As he had said in 1943, the CSR was a ruthless monopoly whose sole concern was to 'produce sugar here in Fiji as cheaply as possible and to sell it abroad as dearly as possible.' The welfare of the local people, their buying power was 'immaterial to them.' Merely employing more non-Europeans in the industry, or sponsoring school essay competitions on the contribution the sugar industry was making to the Colony, or having a mobile film unit travelling around the country showing documentaries on aspects of how the industry worked and how it benefited the local economy, was not the solution to the underlying problems in the sugar industry. All this was done at the growers' expense anyway. Patel was convinced, and he was right as it turned out, that the CSR was indeed interested in a long-term contract, but it wanted to negotiate it from a position of strength, which it hoped to secure if the growers were disunited.

Still, a number of the secondary proposals in the 24 July agreement were accepted by the growers, but the sticking point remained the Federation Committee's insistence that the CSR give an unequivocal undertaking to harvest 80 per cent of each grower's cane, 50 per cent in the first round, along the lines suggested by the Company, and 30 per cent in the second. It rejected the Company's tonnage quota as well as the deadline for closing the mills. The mills should remain open, the growers demanded, until the agreed percentage of cane had been harvested. The 22 January date was detrimental to their interests. There would be a rush to get the cane in, which would produce unseemly competition among them, enmity, burning of cane and further disharmony. In any case, in the past, the Company had kept its mills open as late as March. 'It is unwise to use a wrong key to open a door, to persist is even more foolish,' said Patel. ${ }^{10}$ The counterproposal was signed by all the three major cane growers associations, including the Kisan Sangh (but not its Vanua Levu branch of which Vijay R Singh was the President), the Maha Sangh and the Vishal Sangh. The Company was not about to retreat now when outright victory was in sight. The growers' solidarity was broken. The Labasa mill opened on 11 August. Nonetheless, negotiations continued. On 19 August, A.D. Patel, S.B. Patel and J.P Bayly, who had by now returned to the Federation fold, asked the Governor to intervene in the dispute and purchase the unharvested cane from the growers. The Governor declined. On 31 August, Patel and his colleagues made another proposal. The Federation Committee was:

willing to recommend to all the cane growers that they give on TRUST to the government during the 1960 crushing seasons as much cane as the Government may require to maintain the economy of the Colony on

10 Pacific Review, 8 September 1960. 
the understanding that the Government will take cane from each and every cane grower in approximately the same proportion and the area of cane required to be harvested will be demarcated on the farm before the commencement of the harvest. All other terms and conditions relating to the sale of the 1960 crop will be determined by His Excellency the Governor as to him may seem appropriate.

The proposal was presented to the government through Commissioner Western, Q.V.L. Weston, who had played a significant mediatory role throughout the strike, and discussed by the Governor and his closest advisers, including the Colonial Secretary, the Attorney General and the Financial Secretary. ${ }^{11}$ The effort was well worth it, as it prompted the government into offering a separate proposal of its own. The following day, 1 September, the Governor invited A.D. Patel, S.B. Patel and S.M. Koya to Suva and made a new offer. The Government's proposal was that:

In response to the appeal by His Excellency the Governor and in order to save the national economy of the Colony, to preserve the public peace and to maintain unity among cane growers, we recommend that those farmers who have not accepted the July 24th Agreement should consent to abide by the decision of His Excellency the Governor in respect of the percentage of cane to be harvested from each of their farms on an area basis during the present crushing season provided His Excellency the Governor shall determine the allocation of each farm on an equitable basis as between farmer, bearing in mind that it should be the aim that as far as possible no farmer's allotted area of cane is left unharvested. We appreciate that in the event of hurricanes, floods, strikes, burnings or other unforseen events, the percentage determined by the Governor may not be able to be reached and that the Governor can only make a determination subject to acceptance by the Company. ${ }^{12}$

The three leaders signed the proposal. Omitted from this formula was the CSR's demand about harvesting on a tonnage basis, and there was no fixed date when the mills would close. Patel came away convinced that the government was 'favourably inclined.' But two days later, the proposal was rejected. Patel surmised the reason for its collapse. 'The proposal had to be acceptable to the CSR Company before the Governor could make any award. The fact that it was rejected later indicates that it was thrown out by the unofficial members of the Executive Council who are directly or indirectly behind the 24th July agreement

11 Legislative Council Debate, May 1969.

12 Fiji Times, 1 September 1960. 
or by the Company.' Certainly, the CSR could not have been happy either to see its bitter adversaries extricate themselves from what appeared to be a hopeless situation.

By late August and early September, the situation in the countryside had deteriorated to dangerous levels. Cane fields were being set on fire. Between June and August, over 12,000 tons of cane had been burned through arson, causing over $£ 36,000$ worth of damage. Over 9,000 tons of the destroyed cane belonged to the CSR. By September, another 7,000 tons of cane had been burned. At Drasa, Lautoka, the CSR lost a thousand tons through arson. On 30 August, the government announced that 'it would do all in its power to maintain law and order.' Soon afterwards, as mills opened-Rarawai on 1 September, Lautoka on the 9th and Penang the following day-it deployed special constables and military personnel in the sugar cane belts, particularly in western Viti Levu. Indian schools were commandeered along with jeeps, land rovers and passenger buses. Special constables were posted to protect those who wanted to harvest, the government said. The farmers saw the deployment as intimidation.

Some influential people in the colony wanted the government to take an even stronger stand against the growers' leaders, in particular A.D. Patel. P.J. Bull of Dreketi wrote: 'Let us act against these agitators (who seek to undermine and destroy) by deporting those of them who are aliens and by banishing to some outlying islands (as in the old case of Apolosi) those who were born here. ${ }^{13}$ For good measure, he raised the partly dead horse of Indian non-participation in the war effort. A.J.C. Foster added another dimension: 'When a child fails to respond to coercion, there is only one solution: good hearty wallop.'14

The Fiji Times concurred. Commenting on the dignity and pride with which the Fijian ex-servicemen had marched through Suva, it said: 'They were not like the skulking cowards who hide in the cane fields to destroy by fire the fruits of other men's labour...They were not self-effacing, politically ambitious, emotionally twisted grabbers after power by lies and intimidation.' It urged the government to take advantage of the ex-servicemen's declaration to 'stand on the side of the preservation of law and order. ${ }^{15}$ For their part, the Great Council of Chiefs resolved late in August to 'stand ready to assist in the preservation of law and order and the protection, if necessary, of cane farmers who are prepared to harvest their crops. ${ }^{16}$ Besides their natural affinity with the colonial government, the chiefs also feared loss of rent from the strike.

13 Fiji Times, 9 July 1960.

14 Fiji Times, 30 August 1960.

15 Fiji Times, 22 August 1960.

16 Fiji Times, 29 August 1960. 
Similar sentiments were expressed in the Legislative Council. John Falvey called A.D. Patel the 'villain of the piece/ a man of 'outrageous vanity' with 'clear indications of paranoia.' Ravuama Vunivalu wanted people like Patel to be 'sent where they came from, lock, stock and barrel.' Ratu Mara concurred: 'If Apolosi was considered to be fit subject to be deported from Fiji, why not this certain gentleman whose name was mentioned here yesterday' He assured the Council that the Fijian people 'will see to it' that there was no law and order problem in the country. In Patel's opponents, Mara saw the 'birth of a new type of Indian, which I like and respect.' Vijay R. Singh blamed Patel for having 'successfully divided the Indian community itself into various pieces.' His thoughtless actions had undone a lot of the interracial bridge-building that had been so painfully achieved by leaders like himself. B.D. Lakshman accused A.D. and S.B. Patel, 'who had started their sinister work from 1929 onwards' of being the agents of the greedy Gujarati community 'which was trying to keep people in bondage. ${ }^{\prime 17}$ The Gujaratis were not the cause of the indebtedness among the growers, Patel would respond. The grower was poor 'because he sold at credit. His price was paid over eighteen months. Everyone spoke of him being in debt but no one tried to work out that the CSR owed him money and this was what was making him poor. ${ }^{18}$ If the government was seriously concerned about the problem, why could it not start an Agricultural Bank to lend growers money at cheaper rates, Patel asked. He had first mooted the idea of an Agricultural Bank in 1945.

Meanwhile, in the cane belts, the situation was tense with the presence of the military and with cane fields regularly set to fire. The growers were agitated, confused and apprehensive, their solidarity threatened by the sight of some growers harvesting. They still clung to their demands and condemned those who had signed the agreement with the CSR. If all else failed, Patel told the growers, he would lead a delegation to the CSR in Sydney and to the Colonial Office in London, at his own expense, if necessary. Patel urged the growers not to give up. ${ }^{19}$ 'Do not worry about some people cutting cane. Try to persuade even these few to stop. During a hurricane one should steer the boat patiently and carefully. He should not jump into the sea full of sharks. In this trying time advise the breakaway to come again to the united front. We have yet to make the future contract. Let us not get knocked out in the first round itself. The government follows the Company. Now the alternatives are sacrifice or surrender. Choose the honourable course.' Brave words, but by now the battle had been lost.

From the Colonial Office came the fortuitous announcement that Julian Amery, the Under Secretary of State for the Colonies, would be visiting the South

17 For these quotes, see Legislative Council Debate, 30 September 1960.

18 Legislative Council Debate, 1965, 641.

19 Pacific Review, 29 August 1960. 
Pacific, including Fiji, in October, to discuss a number of subjects, including the strike. Patel and his colleagues seized upon this as a sign of the Colonial Office responding to their demands, which was far from the actual truth, and urged growers to begin harvesting.

Patel and S.M. Koya held a lengthy meeting with Amery in Lautoka on 14 October and briefed him on the events leading to the strike. They urged him to seek moderation from the CSR, and reiterated their views about the uselessness of a commission of enquiry proposed by the government. The problems of the sugar industry would continue to fester unless appropriate and timely steps were taken by both the colonial as well as the imperial governments. Assistance should be given to setting up cooperative mills throughout Fiji; the sugar quotas of Fiji should be divested from the CSR and vested into the Government; as long as sugar was available in Fiji, the CSR should fulfil the quota from Fiji, and not Australian, sugar; the sugar industry should be nationalised and a statutory sugar corporation set up with the government having a 51 per cent share and the growers 49 per cent; a joint stock growers company should be created and monopolies prohibited by legislation. For his part, Amery asked the growers to reconsider their opposition to a commission of inquiry which, he promised, would be thorough and independent. ${ }^{20}$

A.D. Patel and his group had fought hard, but disunity among growers, the CSR's demands and government's reluctance to intervene in the dispute had broken the strike. Most of the growers were dispirited by the prolonged disruption and many were rapidly sinking into indebtedness. Broken and disheartened, they gathered for the last time at the Churchill Park in Lautoka on 15 October, where they passed resolutions against the CSR and the government, the military personnel and special constables, the Indian members of the Legislative Council who had pilloried the Federation leaders in the council debates, and against all those who had signed the 24 July agreement which, it was alleged, had grossly damaged 'the growers' prospects of reaching a favourable settlement with the Company.'21 'Our own lamps were used to set fire to our houses' was how Patel described the signatories to the agreement. Heeding Amery's advice to begin harvesting to salvage what was left of the colony's economy, the growers resolved to harvest their cane during the season under protest, with the promise to plough out their ratoon crop and not plant any new cane until a settlement was reached between the Federation Committee and the Company. Furthermore, they resolved to create a special fund, to which each grower would contribute the gross proceeds of two tons of cane, to compensate those farmers whose cane had been burnt and those who had boycotted harvesting. Nothing came of this resolution.

20 Fiji Times, 13 October 1960; Pacific Review, 20 October 1960.

21 Pacific Review, 20 October 1960. 
The government did what it had promised to do all along, and which the growers had opposed all along (but which the signatories to the 24 July agreement supported). It appointed a commission of inquiry into the sugar industry. It promised that the inquiry would be independent and wide ranging, but the CSR had its own ideas and there seems little doubt that the government's choice was influenced by the CSR's preference. The CSR was against the idea of a full inquiry. Nor did it favour an inquiry comprising representatives of the different interest groups, such as growers and millers, even with an independent chairman. Its own preference was clear: 'The Company believes that a single person should be appointed. Being a sole Commissioner he would not have to make compromises with local members in reaching his findings.' The CSR went as far as suggesting the names of prospective commissioners, including academic economists E.H. Phelps Brown and J.R. Hicks.

The Colonial Office, however, chose Sir Malcolm Trustram Eve, later Lord Silsoe, to head the inquiry. Of his appointment, Michael Moynagh offers this assessment: 'It is hard to imagine a person more representative of the English establishment than Eve. He was Queen's counsel, the First Church Estates Commissioner of the Church of England, a member of the Prime Minister's Committee on the administration of Crown lands, the independent chairman of the Cement Makers Federation, director of the Yorkshire Insurance Company,' and many other such bodies. ${ }^{22}$ By training and temperament, then, Eve was closer to the CSR than to the growers. Moreover, he believed that the CSR itself was not on trial. His role was to 'remove the bees from the bonnet.' Eve was assisted in the inquiry by I.S. Wheatley from the Colonial Office, and accountant J.M. Bennett who, interestingly enough, was connected indirectly to a company which was helping the CSR prepare its case for the inquiry. So, as Moynagh says, 'The inquiry was to be a public relations exercise designed to improve relations between the growers and the CSR.' At the Commission hearings, the CSR was represented by its counsel Ronald Kermode and its senior officials, the Kisan Sangh was represented by D.M. MacFarlane and the Federation Committee by A.D Patel, assisted by S.M. Koya. The Commission sat at Lautoka.

The extensive submissions made to the Commission cover a whole range of issues and concerns that need not be repeated here. We shall discuss only the submission of the CSR and of the cane growers represented by A.D. Patel. ${ }^{23}$ Together, they help to provide a representative picture of the issues facing the sugar industry. The Company argued at the outset that while some of the growers' complaints might have economic foundations, political considerations lay at the root of the problems in the sugar industry. The growers' leaders, A.D. Patel in particular, were using the sugar dispute to advance their political agenda

22 Moynagh, Brown or White, 243.

23 In the transcript of the proceedings of the Commission. 
in the Indian community. The CSR had a proven record of sound and efficient management, the 'system has proved itself and there is no need to vary the present organisation, operation and development,' except in minor details. The sugar market was tight, the Company argued, and unless some further sugar quotas could be secured, no further expansion of the sugar industry should take place.

The growers themselves were a large part of the problem, the Company argued. Too many of them lived on the cane farm and expected to earn a good living from it. The growers lacked discipline and diligence, employing casual labour and substitute cane cutters to perform work which they themselves could and should have done, using their own equipment and livestock. It was these tendencies, rather than any Company policy, which strained the growers' income and increased their indebtedness. The growers complained about the Company dividing the farmers to serve its own ends, and fragmentation was a problem, but it was the growers' own leaders who were responsible because the division 'has been mainly for political purposes.' The CSR denied that it was making the excessive profits alleged by its critics. In its view, it was the growers who had been receiving a larger share of the industry's proceeds than had been intended or could be justified. The truth was, that 'the miller's share of the gross income has dwindled to such an extent that his profits are inadequate and unsatisfactory' to maintain milling infrastructure efficiently.

When Patel opened his case, the tension between him and Eve was palpable. The CSR had been allowed to open its case with little interjection from Eve, but with Patel, the Commissioner was combative. He seemed determined not to let Patel come out on top, as the CSR had advised privately. The differences between Patel's group and the CSR were fundamental. Whereas the CSR had suggested minor changes in the sugar industry - to remove the bees from the bonnet-Patel advocated fundamental restructuring of the industry. The CSR was a monopoly, he argued, which 'treated Fiji as a closed shop for all time to come.' This monopolistic situation enabled the CSR to dictate terms to all the parties in the sugar industry; even the government itself was not free from its influence. As if this was not bad enough, Patel went on, the monopoly operated by 'remote control' from Sydney. Even the commission itself would have to travel to Sydney to examine the company's account. 'If the Commission cannot have the company's books produced in Fiji, I very much doubt whether the Inland Revenue can get them here.' And he showed how the company had used book-keeping practices to deprive the colony of revenue by citing the example of molasses pricing. The price per ton of molasses from 1934 to 1960 had remained constant at $£ 1$ per ton. There was no other commodity in the world which had remained at a constant price except molasses which the CSR manufactured and sold to itself. In Jamaica, comparably situated, molasses was 
valued at $£ 7$ and ten shillings per ton. 'If I am correct in my assumption that the value of molasses exported to Sydney should be at the same price prevailing in Jamaica and British Guyana, it means that the Company - and I don't like to use strong language but I am compelled to use it here-is cheating the growers to the extent of $£ 300,000$ a year.'

That was a very sorry state of affairs, Patel told Eve. He wanted the Fiji government to pass legislation compelling the CSR to keep its book of accounts in Fiji, which should be audited by the government's own audit department. Further, the Company should be obliged to produce their books to commissions of inquiry and courts of arbitration, or any other responsible authority such as the Commissioner of Inland Revenue. Another measure to control monopoly in the sugar industry was to introduce an element of competition. Establishing grower-owned cooperative mills was one sensible solution, Patel suggested. ${ }^{24}$ These mills could be located in rural areas, thereby alleviating the problem of rural unemployment. Moreover, the mills would do away with the processor middlemen, and the growers, as shareholders, would be the beneficiaries. The growers must prepare to stand on their own two feet, establish their own cooperative mills and become the processors as well as producers of their cane, said Patel. There was no other alternative if things did not change. Eve would have none of this proposal. The following exchange captures the general tone between Patel and Eve:

Eve: Won't they want to make as much profit as the CSR Company?

Patel: Yes, but these profits will go back to the growers themselves. They are going to make those profits.

Eve: But those profits will go into the pockets of the shareholders and the shareholders happen to be cane growers. I thought you wanted the processing made without profit?

Patel: What I meant was that it would cut out the outside middleman's profit.

Eve: I cannot see that. Any profits that will be made will go back to the shareholders.

Patel: They will not go to an outsider.

Eve: They will go to the shareholders who will happen to be the growers. They will be the same profit.

Patel: But those profits will go to the growers.

24 See also Legislative Council Debate, 12 May 1969. 
Eve: Who will be the shareholders and will have put up the capital.

Eve was adamant, and Patel moved on to another proposal to rein in the CSR. This was the creation of a Sugar Board. Fiji, he said, was the only country under the Commonwealth Sugar Agreement where the government exercised no control over the industry, which worsened the situation in the event of strikes or other disruption to the industry. A Sugar Board, properly constituted, preferably with the concurrence and assistance of the Imperial Government, with its members drawn not from Australia, New Zealand, Fiji or India, but from countries like the United Kingdom and Canada, could reduce suspicion and misunderstanding between the growers and the millers. 'It can establish industrial peace and good relations in the industry; and it can ensure a fair and equitable distribution of rewards to both sides.' It could oversee the smooth functioning of the industry, ensure compliance with agreements reached between growers and millers and, if need be, take over the marketing and selling of sugar as well. Similar boards existed in Mauritius and Queensland, Patel told Eve, where they had worked well.

Another important function of the Board would be to the negotiate Fiji's sugar quota in the British Commonwealth Sugar Agreement and the International Sugar Agreement. The quota negotiated belonged to the sugar industry as a whole, on whose behalf it was negotiated and obtained, Patel argued; it was not the CSR's 'personal individual property,' as the Company claimed. The growers had no say in its negotiation or its content; instead, they were hostages of the Company in the matter of quotas. An independent Sugar Board, made up of government, Company and growers' representatives, should represent Fiji's sugar industry in the international arena.

The Sugar Price Stabilisation Fund was another bone of contention between the CSR and the growers, and Patel wanted it abolished. The Fund was created in 1946, without the growers' consent, to cover contingencies such as depression in the world price of sugar, and to promote experimental research into new varieties of cane, disease control, and public education through the Company's mobile film unit. The growers paid three and a half shillings per ton as their contribution to the Fund.

Overall, their contribution was 75 per cent, and the Company's 25 per cent. But when the money was paid back to the growers, they received only 66.5 per cent instead of the 75 per cent they had contributed, while the CSR share rose to 35.5 per cent. A cane grower who produced 120 tons of cane paid $£ 21$ into the Fund. That was substantial sum of money, especially as many growers were in debt and often paying interest of around ten per cent. Meanwhile the Fund was invested at a much lower rate in such a way that some penalty was often incurred when the money was withdrawn. Patel argued that the Fund was 
'inadequate for its purpose and is unjust to the growers.' In the event of a real depression, he said, the Fund could keep the price of sugar at an economic level for no more than a year, after which the 'grower will be in the same position as he would have been without the Sugar Price Stabilisation Fund.' He wanted the Sugar Price Stabilisation Fund repealed, and the funds 'divided in the actual proportion in which it was contributed to by both the growers and the miller under the Agreement and that the further collection or deduction of the Price Stabilisation Fund be discontinued.'

Was this in the Commission's terms of reference, Eve asked Patel, and a heated exchange followed:

Patel: It comes under the reorganisation of the industry and I am telling you why it is not in the best interests of the industry and the Colony. It is on those grounds I ask you to advise and recommend.

Eve: You are content for the present and the future? It is all right?

Patel: For the future we advocate that the deductions be discontinued.

Eve: It is all right, isn't it? May I put it quite slowly: for the present and the future you have no complaint about this measure and...

Patel: ... .and of the division part, yes.

Eve: It is only for the past.

Patel: For the past.

Eve: I may say at once, I think you will find it a little difficult to recommend retrospective legislation.

Patel: That is for you to consider.

Eve: Well, I am telling you.

Patel: I am doing my part.

Eve: Yes, certainly, so am I.

Patel: I cannot presume to take over your part, Sir.

On the question of estimating the costs of production, Patel and the CSR were poles apart. The Company, it will be recalled, had portrayed growers as a generally un-enterprising lot who palmed off work to others and yet expected to earn a good living off the farm. Patel disagreed. The Commission should look on the grower as a seller of commodities and not as a seller of services; whether he worked himself or employed casual labour, the value of the labour should 
be included in the cost of production. Whether the grower harvested the cane himself or engaged a cane cutter, the value would be just the same as far as the cost of production was concerned. 'If the Company say that the grower is merely a worker who has no business to get an outsider to do his work, I am in entire disagreement with that principle. We cannot take into consideration when assessing the price of cane, as to how much it takes for a grower and his family to live on as we would, for instance, do in the case of workers when assessing their wages. Their wages, more or less, have some relation to the cost of living and how they live and their standard of life. As far as the growers are concerned, if they are producing more and selling more, they are getting more money, but if they sell less, they get less money. If they are careful they can save money. If they are improvident and they squander their money it is not our look out.' It was as simple as that. But Eve remained unmoved.

Indebtedness among of the growers had been raised by the CSR in its submission, incurred, it had said, through foolish investment. Indebtedness was a problem, Patel agreed, but he disagreed with the CSR about its causes. It was, he said, a direct result of rural unemployment. People bought tractors or lorries to set up a member of the family in productive employment. 'Probably the farmer thinks that if he buys a tractor one of the boys can work the tractor and go and plough for the neighbours on hire and make an income from that. It is not that the owner just wants to buy a tractor for a small 10-acre farm and he himself wants to have a tractor instead of a pair of bullocks for his own farm, but this is the way to get some sort of work or occupation for a member of his family' Growers incurred debts to educate their children, to equip them with technical training so that they could find employment outside the sugar industry.

Moneylenders added their share to the problem, Patel said. They made loans on very high rates of interests, partly because the banks were reluctant to lend money.

There were no easy solutions, Patel conceded. Nonetheless, he made a number of proposals to alleviate the situation. One way to control the credit squeeze and resort to the money lender was to make more credit available at the cheaper rate and introduce an element of competition in the field of money lending.' Another was to force the CSR to make its cane payments as soon as possible after the harvest, thirty days from delivery and no further than April for the final payment, which would obviate the need for the farmer to buy goods on credit or incur debts for other reasons. The third solution Patel proposed was diversification. Additional land should be found for surplus rural population, and the planting of alternative crops should be encouraged. Cotton was one crop that could be looked at, he said. 'Sea Island cotton is very famous throughout the world and gets higher values than other varieties grown in other countries, and we've got at least two markets which are in need of staple cotton-India 
and Japan.' Diversification, Patel said, 'will take pressure off the cane growing areas. It will bring the value of the cane lands down, it will bring the rents of the cane lands also down because there is competition just now to secure cane land...It will expand the economic development of the country and will benefit the people all round. What we urgently need is to take pressure off the surplus population from the cane fields and speculate on other profitable lines.'

The gulf between Patel and the CSR was as great as ever. Patel's distrust of the Company remained. 'I am convinced more than ever after reading what CSR officials have given that the Company is adept at juggling figures as it suits them.' And he questioned why the CSR officials in Fiji were paid so handsomely. 'We have at this Inquiry heard time and again that when the question of labourers or ordinary workers was concerned, it had always to be borne in mind whether the wages asked for are economically sustainable or not. The question naturally arises whether the Company has two different standards, one for the staff and one for the labour. If they want to have an economically sustainable wage, why not economical salaries for staff? Why should their staff be paid on the standards of living in Australia and not on the standard in Fiji?' A fair question but an unrealistic prospect in colonial Fiji.

It was a long and deeply contentious inquiry. Eve was aware of this. Concluding his inquiry, he said: 'I have put some questions of a fairly hostile nature to all the four parties. I hope I have been reasonable with everyone and I don't want anyone to think that because there has been a hostile question from the Chair that is the view of the Commission. It is a way of getting the real facts out. I take some small bit of credit that I provoked most people and it has helped to get out the stuff we wanted to hear. But please do not think that what Counsel have said or what questions they have put have, in fact, proved anything any way. I hope everyone will keep their judgement till they read our report.'

The Eve report was published in $1961 .{ }^{25}$ On most of the major points, Patel and his group had lost, their demands for accountability and equity in the sugar industry either denied, deflected or diluted in the recommendations. The idea of cooperative mills was rejected outright as being impractical. The growers had not learned to manage their farms without supervision, how could they be trusted to run efficient mills? The Price Stabilisation Fund was not abolished but future levies were. Patel's idea of a Sugar Board with teeth was ignored in favour of an advisory sugar council. Eve underlined the point for all concerned: 'The word advisory shows that its members are not to decide anything. They are to discuss all problems, to advise the industry, to advise government and to try to solve any difficulties.' This view was supported by the Kisan Sangh. On the question of molasses, about which Patel had submitted at length, Eve 
acknowledged that the CSR had done well under the old agreement, but it had not violated the terms of that agreement; he did agree, however, that the price should be raised though not to the level demanded by the growers. On the question of production control, Eve acknowledged the difficulties involved but came out in favour of control by tonnage than by acreage.

Eve endorsed the idea already being mooted privately by the CSR of forming a wholly owned subsidiary for managing its Fiji activities. The result was the creation, in 1962, of the South Pacific Sugar Mills Limited. And on the vital question of sharing the cake, Eve recommended that 30 per cent of the net proceeds be allocated to the CSR to cover its sugar making costs, thus protecting the Company against losses but not the growers. The growers' basic share of the proceeds was 57.75 per cent, which was closer to the CSR offer of 55.1 per cent than it was to the Federation's demand of 66.3 per cent. It was also less than the 62.6 per cent the growers had obtained under the 1950-59 contract. ${ }^{26}$ The CSR was pleased with the report. Deputy General Manager G.M. Dixon wrote to the Company's London agent on 22 September 1961: 'The Commission obviously had to criticise the Company for something. All the major points which the Company had included in its draft agreement as put to the growers, and all the major points we wished the Commission to rule on, are covered in the report or a recommended contract in a way which is very satisfactory.'

Everyone connected with the industry was to share blame, Eve wrote. The government was to be blamed for not heeding Lord Shepherd's recommendation for a sugar advisory board which, had it existed, could well have averted the strike. Eve agreed with the CSR's contention that its income from the industry had become inadequate and un-remunerative, but said that its behaviour towards the growers was inexcusable. The Company claimed it could not pay the high price of cane demanded by the growers yet, Eve said, 'they did not produce for the growers any accounts of any sort at any stage until our public hearings. This was no way to deal with people who admittedly were to have a share of the sugar proceeds.'

But this reprimand was nothing compared to what Eve had to say about the growers' leaders, and Patel in particular. For a start, Patel and other leaders of the Maha Sangh had deliberately caused disruption in the sugar industry in the hope of gaining advantages for themselves and of trying to drive the millers out of Fiji.' The sugar industry had become a vehicle for 'ambitious politicians.' Then, in an unusual and unprecedented move, Eve singled out Patel for special criticism: 
We have pondered deeply upon the intentions of the leader of the no cutting campaign. We hoped that we might discover some evidence that the policies advocated by him were directed towards the improvement of the growers' lot. We realise that the attitude of the millers could well have antagonised him and the withholding of financial particulars could have given him cause for suspicion. None of this however justifies the form and extent of the no cutting campaign particularly after the offer of an inquiry. His conduct has been so obviously against the interest of the growers as to lead us to advise them that his policies at the time should not have been followed. We hope that his future conduct may change and that he will show far greater sense of responsibility to the country of his adoption. We are satisfied that this leader is a very able man, and that he could provide sorely needed leadership of the right kind. ${ }^{27}$

Eve's harsh tone was not unexpected given the tenor of the exchange between him and Patel during the hearings and the ideological gulf that separated the two men, not to mention their vastly different understandings of the fundamental problems in the sugar industry. Some of Patel's proposals do seem infeasible, such as establishing cooperative mills. The idea had its appeal, but the growers did not have the technical know how to run such a vast industry on their own. Nor, would the government allow the colony's major industry to be dominated more than it already was by the Indian community. Some in the Kisan Sangh thought the proposal was a plot for a Gujarati takeover of the sugar industry. Both B.D. Lakshman and the Kisan Sangh had publicly opposed the idea of a strong Sugar Board, and both had wanted to exclude lawyers serving on such boards. Eve was thus aware of the divisions among the growers. And he was well briefed about Patel as well. In a confidential memorandum prepared for the Commission, the CSR went out of its way to portray Patel as the chief villain of the piece. The tone and indeed some of the words in the CSR's memorandum are echoed in Eve's report. The CSR had said of A.D. Patel:

There would seem to be no doubt that A.D. Patel is a very ambitious man, and from his actions over the years, it seems that political leadership of the Indians, and in time of Fiji, is his aim. He possibly pictures himself as the first Prime Minister of a self-governing or substantially self-governing country, with the control of the sugar industry. Thus, any other Indian who comes to the fore as a leader and a possible rival must be put down, and if in doing this, the sugar industry suffers, A.D. Patel is apparently unconcerned. If the situation is as described, and the pattern seems quite clear over the years, the real reason for the recent troubles seems manifest. The more important question is how much can 
such a man be relied upon to act responsibly in the interests of the Sugar Industry (and not of his own political advancement) in the future. No leader who had the welfare of his supporters at heart would tell them to burn their crops, plough out ratoons, and do no planting, as he would well know that such advice must result in his supporters becoming ruined, or at least being left very heavily in debt. ${ }^{28}$

Such an allegation by Patel's principal adversary is understandable; but for Eve to make them himself does seem curious. As Patel said, here was a Queen's Counsel, a member of the British Bar, who had not followed the elementary procedures of natural justice. At the very least, he would have expected Eve, after passing any judgement, to give him the fullest opportunity to respond. Patel's own judgement of Eve was equally harsh, but he himself remained philosophical: 'There are two sides to a man's action: on one side is praise, on the other side is blame; on the one side is honour, on the other side is insult. But my religion has taught me to do your duty unaffected by praise or blame and without expecting any reward for what you do. ${ }^{29}$ Assuming that Patel's political ambitions were a factor, to attribute all the troubles of the sugar industry to the political ambition and vanity of one man seems far fetched. Such a characterisation portrays sugar cane growers as passive and ignorant people who did not know what was in their own best interests, which even a cursory knowledge of Fiji's cane farming community would find grossly unfair. And it needs to be explained why, if Patel was such a personally ambitious man who cared little for the interests of his people, why he would be returned to public office in election after election, making him the dominant political figure in Fiji in the 1960s? The Fiji Samachar put the whole issue succinctly: 'We are totally against the policy of A.D. Patel but are compelled to ask why he is such an outstanding person that the majority of the farmers are under his influence, and even the members of the Legislative Council and farmers' representatives have failed to disperse it? ${ }^{\prime 30}$

So what of the whole commission exercise? Michael Moynagh:

The Eve inquiry had been an astute political exercise. Under the guise of impartiality, a report which was distinctly favourable to the CSR had been produced. Despite opposition from the leaders of the Federation, in early 1962 growers signed a new contract based on the commission's findings. Later there would be complaints that the farmers had been forced to do this because there was no alternative. Growers were financially drained and thoroughly disheartened from the strike two years before, which had cost them an estimated $£ 850,000-£ 900,000$ in

28 I am obliged not to reveal the source of this quote.

29 Legislative Council Debate, 21 April 1969.

30 Editorial on 7 October 1960. 
lost income (CSR had also suffered, making a loss on the 1960 season). They were in no mood to start industrial action again. The position of the CSR, supported by the government and Fijians, seemed unassailable. The implementation of most of the Eve report was extremely important for the sugar industry. The method of production control, the Sugar Board and the Sugar Advisory Council still exist today. CSR's continued presence in the colony - for at least another ten years - was assured. ${ }^{31}$

Those ten years were crucial ones in the history of Fiji. Political change, its nature and pace, would dominate discussion, but in the Indian community, particularly in the sugar cane belt, the issues surrounding the strike, why it was started and why it collapsed, the role played by certain individuals in prolonging or terminating the strike, the poverty and the suffering caused by the application of the Eve formula for sharing proceeds from the sugar industry, would continue to be debated with great emotion and controversy. The Company and the kisan would confront each other again a decade later, but with different results. Meanwhile, the slogan chanted at virtually every major meeting of cane growers throughout Fiji was 'You Can't Trust Eve.'

31 Moynagh, Brown or White, 216. 



\section{Chapter 8: Towards Freedom}

The winds of political change are blowing all over the colonial territories and Fiji cannot hope to remain unaffected.

\section{A.D. Patel, 1963}

Won't it be better if we thought less of our race and more of our nationality?

\section{A.D. Patel, 1964}

'Independence will surely come to Fiji, if not today, tomorrow, or in two or four or ten years time, whether we wanted independence or not,' said A.D. Patel in 1964. 'But what kind of independence should we have?'1 That was the main issue which occupied Patel for the remaining five years of his life. The inevitability of independence seems so obvious now, the pattern of decolonisation of the Pacific so clearly discernible, the dismantling of colonialism so inevitable, but it was not so in the early 1960s, when it provoked heated debate and acrimony in Fiji. Patel's quest was seen by his opponents as yet another of his crafty schemes to rid Fiji of the British. Ratu Kamisese Mara, ascendant Fijian leader and independent Fiji's first Prime Minister, was less enthusiastic. 'We are not as stupid as that' [to ask for independence], he told the American reporter Homer Bigart in 1961. 'What would we get out of it? We can't even pay for our own food. We would have to pay for everything. There would be no advantage in independence.' ${ }^{2}$ One must not tear down old houses before building new ones, Mara advised. A correspondent to the Volagauna put the same thoughts in a different way: 'The desire for prompt independence is similar to a young boy who wants to get married when he is not self-supporting. It is obvious that he will get married when he is well off. Similarly the time of independence will come but all the necessities for good independence are not in hand yet.' ${ }^{3}$

Patel disagreed. 'Who does not want to be free? Even birds and animals want to live in freedom. It's the British colonialists who do not want us to be free.' As far as he was concerned, Fiji was ready for independence. 'People of Fiji compare their lot with that of the people of Hawaii and do not fail to observe the vast contrast. When Fiji is compared with Samoa which now stands on the threshold of independence, the contrast becomes even more glaring.' Patel advised government officials 'not bury their heads in sand ostrich-fashion and pretend that [the] people of Fiji want no political changes. It is often said that

\footnotetext{
Jagriti, 16 November 1964.

Reprinted in Fiji Times, 10 January 1961.

Vohgauna, 11 October 1963.
} 
Fiji will be the last colony to go out of the British Empire. That may be so. But it may not be very long before she goes.' ${ }^{4}$ Patel was closer to the currents of international thinking than his political opponents.

The United Nations General Assembly had passed a resolution on 14 December 1960 which had defined colonial domination as a denial of fundamental human rights and contrary to the charter of the United Nations. It was accepted that all peoples had the right to self-determination which entitled them to determine their political status. 'Inadequacy of political, economic, social and educational preparedness should never serve as a pretext for delaying independence.' The tension between these opposing views, the desire for independence or at least some change towards a greater degree of internal self-government on the one hand, and the reluctance or even fear to contemplate it on the other, dominated the public debate in the 1960s.

Patel's standing and prestige in the Indian community had soared after his performance during the Commission of Inquiry. Soon after the report came out, the cane growers realised how harmful Eve's formula was for them; even those who had signed the 24th of July Agreement agreed. Inevitably, perhaps, the strike became the central issue in the 1963 election campaign for the Legislative Council. This was the first time since 1953 that Patel was contesting an election. It was a historic election in many respects. ${ }^{5}$ For the first time the Fijian people were given full, universal franchise; before then, it may be recalled, all Fijian members of the Legislative Council were nominated by the Great Council of Chiefs and appointed by the Governor. And, for the Indian community, it was the first time a quasi-political party was sponsoring candidates. That party was the Citizens Federation, the political wing of the Federation Committee. It was a rudimentary organisation, without a constitution or a manifesto or a platform, beyond the rhetorical pledge to promote 'economic, cultural and political progress and stability,' with 'trusted, proved, able and valiant leaders,' who would work together to create a united Fiji. The Federation, its leaders said, 'will stand for amity and equality of all sections of the community.' The party would 'of course, uphold the legitimate interests of the Indians but at the same time will work with the same fervour for the interests of Fijians, Europeans, Chinese and all others in Fiji.' Its approach would be 'straightforward, open and constructive.' The more interesting point is that for the first time a team was being offered to the electorate rather than individuals standing on their own.

Federation candidates for the election were Patel himself, Siddiq Moidin Koya and James Madhavan. It was an attractive and unique slate of a Hindu, a Muslim and a Christian, all three standing on the same platform for one political party,

4 Pacific Review, 11 February 1960.

5 For one study of this election, see Meller, 1968. 
the representative party, it hoped, of all Indian people. Patel did not want to stand for the election, saying that people would once again accuse him of using the strike to gain political mileage for himself. That was the reason why he did not contest the election in 1960 even though both B.D. Lakshman and James Madhavan had offered to withdraw their nomination from their respective constituencies if Patel decided to stand. In 1963, his nomination papers were prepared reportedly without his prior knowledge by M.K. Pillay and Swami Rudrananda. When Patel found out, he went straight to the Swami who had agreed to take the responsibility for the surreptitious action. Swamiji was blunt: 'Look Patel, whenever the public needs you, you are there. The public cannot do without you, and you cannot do without the public. You have no choice but to stand. ${ }^{6}$

Koya had risen to public prominence during the Eve Commission hearings. He was born in Ba in a prominent Malayali Muslim family. After primary education he never attended secondary school - he worked as a clerk in S.B. Patel's Lautoka law firm and later for Tulsi Ram Sharma. From there he went on to Auckland University and then to the University of Tasmania to obtain his law degree. The University of Tasmania for some odd reason trained a disproportionately large number of Fiji's earlier generation of lawyers. During the 1950s, Koya was an active member of the Kisan Sangh, as many prominent Ba families were, but he switched to the Patel camp later that decade, encouraged by his father, Moiddin Koya, who had known and admired Patel for a long time and whom Patel had successfully defended in a serious criminal trial.

Siddiq Koya was one of those who had persuaded Patel to lead the cane growers in the negotiations with the CSR. At public meetings, Patel praised Koya for the enormous amount of work he had done during the hearings. Koya had passed the agni pariksha, the test of fire, Patel said, and was a great asset to the Indian community. A big, burly man, emotional and ebullient, a good criminal lawyer, and a rousing, chest-thumping, no holds-barred orator, Koya could always be counted upon to work a crowd, to give masala (spice, punishment) to his opponents. He was the perfect lieutenant for the cool, analytical Patel. After Patel's death, Koya would inherit the leadership of the National Federation Party, though not Patel's authority or his unchallenged mastery of the party machinery. James Madhavan was a prematurely grey haired South Indian Christian, a primary school teacher, a modest, moderate man well known for his selfless community work. He had first entered the Legislative Council in 1947, and served continuously until his death in 1973.

All three Citizens Federation candidates were elected to the Legislative Council, though Koya and Madhavan after particularly gruelling campaigns. Madhavan's

6 Communication with M. K. Pillay. 
opponent in the Northern Division was Harish Chandra Kohli, a wealthy, Indiaborn Labasa lawyer who had been endorsed by the Kisan Sangh. Madhavan polled 2,756 votes to Kohli's 2,154. Koya's opponent in the north-western Viti Levu Indian seat was James Shankar Singh. An insurance agent, Singh came from a very large and influential Kisan Sangh-supporting clan in Ba. He was expected to defeat Koya handily. In this campaign, as in many others before and since, religion was used as an issue. Singh was an Arya Samaji who had converted to Christianity, whereas Koya was a Muslim. Shafiq Koya, Siddiq's elder brother, told me an interesting anecdote about how Patel responded to the campaign call for all Hindus to rally behind Singh. How could a Muslim be elected from a predominantly Hindu electorate? Without referring to Singh directly, Patel began a campaign speech by telling the audience about what he had been told. Then he said, 'Janab Koya Musalman to hain, yeh sahi hat, par apne dharam par we atal hain, badle to nahin.' ['Yes, Mr. Koya is a Muslim it is true, but at least he has remained true to his faith.'] By implication, Singh had betrayed his community by converting to Christianity. Religion did not surface as an election issue again. But $\mathrm{Ba}$ was $\mathrm{Ba}$, the heartland of proud, wealthy landowning families, supporters of the Arya Samaj and the Kisan Sangh. It was not surprising then that the campaign was tense with occasionally frightening incidents of violent clashes between supporters of the two rival factions. Still, in the end, Koya defeated Singh, though only by a narrow margin of 3,998 votes to 3,480 .

Patel's own seat attracted even more interest, for the election was seen as nothing less than a referendum on his role in the 1960 strike. Making the contest even more interesting was the fact that Patel's opponent was none other than the president of the Kisan Sangh, Deo Sharma, a Fiji-born North Indian lawyer based in Patel's home town of Nadi. But Sharma proved no match for Patel. He was young and inexperienced. Why hadn't Sharma appeared for the Kisan Sangh before the Eve Commission, instead of D.M. MacFarlane, people asked? What was his record of public service? Sharma said that the real reason why people were suffering was because Patel had stubbornly refused to sign the 24th of July agreement. Patel was not really interested in the welfare of the farming community, he told his campaign rallies, being bent on mortgaging their future to the Gujarati shopkeepers. That was his sole hidden agenda.

Patel was a stubborn man, 'jiddi,' his opponents said, who would not budge even though he knew he was not going to win. Was Patel stubborn? Patel himself did not think so, and he confronted this accusation by citing, as was his wont, religious texts. At one meeting he said 'Rama went to forest to fulfil his father's promise to his (Rama's) step-mother (Keykei). He was not commanded by his father to go to the forest. After the death of his father, the three wives of his father, including the step mother and her son, Bharata, for whom she 
wanted the crown, went to Rama and requested him to return to the capital and assume the reign of the kingdom. The mothers, brothers, the royal family priest and preceptor, state ministers and all the citizens beseeched Rama. But he refused for he wanted to fulfil his father's word. This is not obstinacy, though requested by all. Rama was standing for a principle.' He quoted a passage from the Mahabharata, where Duryodhana refused to follow what he knew to be the right path. That, Patel said, was obstinacy. Patel was comparing himself to Lord Rama and the great sages of India, his opponents said. It was all reminiscent of the election campaign of 1937 when Patel had said that many of the people in the indenture days were born in the cane fields because of the oppression of the CSR. That remark, it will be recalled, had been twisted and used against Patel.

Patel's and Koya's promise to go to London, at their own expense, to present the growers' case to the Secretary of State for the Colonies was a ploy, a charade of selfless service, Sharma said. Patel's motives were suspect. The real reason was that Patel wanted to visit his sons Atul and Dhimant who were enrolled at an exclusive private school in England in 1959. Patel rejected the charge. He and Leela had visited them only a year ago, in May 1962. The reason he had abandoned his plan to go to London, Patel said, was the announcement by the Colonial Office that the Under Secretary of State for the Colonies, Julian Amery, would be visiting Fiji, and that it would be better for the growers to present their case to him in the colony itself. Amery did not come to Fiji to solve the sugar dispute, Sharma said, but his opponents countered that Amery spent more time discussing problems in the sugar industry than any other issue. And so the campaign went. In the end, Patel defeated Sharma by one of the biggest margins in the 1963 elections, winning 6,244 votes to Sharma's 3,346.

The third candidate in the western constituency, Mahadev Singh, got only 72 votes. So, A.D. Patel entered the Legislative Council in 1963, after an absence of thirteen years. He would dominate its proceedings for the rest of the decade. When Patel spoke, people listened. Ratu William Toganivalu, perhaps echoing the feeling of many members of the Council, said that he listened carefully whenever Patel was on his feet. He did this out of respect for Patel as the senior member of the Council. 'He was here when my father was a member of this House many years ago.' And he listened carefully and intently because 'I am learning something from the eloquent way in which he delivers his address. There is magic in his delivery.' Patel's mastery of parliamentary procedures, his impressive command of detail, enormous powers of concentration, facility with the English language, and a cool, analytical approach made him an outstanding debater. 
A.D. Patel's maiden speech in the Legislative Council on 23 August 1963 provides as good an example as any of Toganivalu's point. ${ }^{7}$ The Traffic Amendment Bill had been introduced to limit the number of taxi licenses issued to local operators, to curb 'the overcharging, touting, cut-throat competition and extracurricular activities' of taxi drivers. Patel opposed it, as also did Ratu Mara. Patel called the Bill wrong in principle and, if enacted into law, harmful in practice. The taxi industry was not the only industry which was facing the problem of overcrowding and competition. 'Now suppose tomorrow the cafe owners came before this Council with a request, 'Please limit the number of cafes in this Colony;' the shoemakers coming with the request to limit their number, and farmers coming, with far more justification, to limit their numbers because of shortage of land and pressure on land, and the labourers, who are last but not the least, coming with a similar request to limit their number as far as that particular employment is concerned.'

What would be the result? 'It would only mean this: instead of living in an open society, in a free society, we will all be going towards a closed society with advantages for few, disadvantages for many.' If enacted into law, the Bill would create more problems than it would solve, Patel went on. How? 'It would harm the public; it will affect business people who are selling their vehicles; it would affect mechanics in the Colony; it would affect the livelihood of drivers.' To the argument that the bus industry was controlled by the Transport Control Board and that a similar body could control the taxi industry, Patel reminded the Council of the essential difference between the two. Buses served the community, while taxis served individuals. 'The passengers have no choice as regards the time when they can get on the bus; they will have to wait for the bus to arrive. They have no choice as to who their fellow passengers will be; they have to take the passengers in the bus as they come. They cannot direct the bus to drop them where they like; they have got to get down at the appointed station and at the appointed terminal. And, they cannot make buses wait; they have got to wait for the buses.' But with taxis, it was a completely different story. 'You can order it and use it at any time for the services that you require. You can take it as long as you like, you can make it pick you up from anywhere and you can make it drop you anywhere you like.' Service of this personal nature was important to the people of Fiji, Patel went on, and public consideration should be uppermost in considering the Bill. Limiting the number would not benefit the public. 'Competition is the essence of efficiency and good service.' Healthy competition, regulated by law, was the best public policy for Fiji, Patel argued.

What guarantee was there that limiting the number of taxis in the industry would curb touting and other extra-curricular activities of the drivers? Patel asked. 'Limiting the number does not set the wrong right. It is competition

7 This speech and others quoted later can be found in the Hansard of the Legislative Council. 
which will bring about things that the public require in taxi service; passengers want their taxi driver to be an honest man, a courteous man and a very competent driver in whose hands they can trust their life and limb. What the individual requires is some comfort and safety as far as the vehicle is concerned, and that can only be brought about by competition, not by laying down rules and limiting the number.' The Transport Control Board wanted to take upon itself the responsibility to safeguard the interests of the general public, and ensure a reasonable standard of living for those engaged in the industry. 'Who is going to decide what is the reasonable standard of living for any particular industry? I think in every industry we have to leave it to the individuals who are engaged in it, and to the economic conditions prevailing in the industry, as well as outside. It is the natural law of supply and demand which determines the standards of living in that particular industry.' The imposition of control encouraged evasion, subterfuge and dishonesty Patel suggested. And the Bill vested too much power in the hands of one body, the Transport Control Board, from whose decisions there was no appeal. The Bill gave the Board the power to increase or limit the number of licenses issued. But the government was being disingenuous. The words 'to increase' were 'superfluous and redundant,' Patel said; to 'limit' was the real gist of the bill. 'Increasing the number is not in their hands. The number can only increase if there is an increase in demand, and if people who want to enter the industry consider it is worth their while to invest the money to purchase cars and put them in the taxi industry.' And public interest was not going to be served by this action. Free and fair competition, regulated by law, was the best way forward. These words, cold in print, do justice neither to the man nor to the moment. But they do show a logical mind, fluent, flowing, in full cry.

Patel was not long in the new Legislative Council when further constitutional changes were announced by the Colonial Office. Ever since the late 1940s, Britain had been gradually increasing the degree of self-government in the colonies. By then, as we know, colonialism was being dismantled in other parts of the world, beginning with India in 1947 and in various Asian and African countries in the 1950s. In the Pacific, Samoa gained her independence from New Zealand in 1962, and Cook Islands followed in 1965. In Fiji, giving the Fijian people the right of universal franchise was the first step in the direction of constitutional change.

Once the election was over, the Governor introduced the 'Membership System,' which came into effect on 1 July $1964 .{ }^{8}$ It was a small but significant step in the direction of greater internal self-government. For the first time, the Executive Council had three elected members on it, all of whom were placed in charge of a group of government departments. John Falvey was appointed the Member for

8 Following the Secretary of State for the Colonies Despatch No. 388. 
Communications and Works, which included responsibility for civil aviation, electricity, hotels, marine, meteorology, postal service and telecommunications, transport, tourism and public works. Ratu Kamisese Mara was appointed the Member for Natural Resources, being in charge of agriculture, co-operatives, crop processing, fisheries, forestry, geology, lands, livestock, marketing, mining and soil conservation. And A.D. Patel was appointed the Member for Social Services and placed in charge of cultural activities, education, health, prisons, social welfare and charitable societies. The other major portfolios were controlled by official members, by the Colonial Secretary, who was responsible for the civil service, constitutional, consular and defence matters, external affairs, immigration and emigration, labour and the police force; by the Financial Secretary who controlled banking and budget, commerce and industry, economic planning, exchange control and fiscal policy, by the Attorney General under whom came matters relating to law and order, the drafting of legislation and provision of legal advice to all government departments. There was a separate office for the Secretary for Fijian Affairs and Local Government.

Patel accepted the appointment but only on certain conditions. One concerned the nomination of the second unofficial Indian member to the Executive Council. Chirag Ali Shah was the first nominated member. The government wanted to nominate Andrew Deoki. It approved of Deoki for several reasons. Deoki had been in the Legislative Council before, he was a prominent Suva lawyer and a Methodist, so his appointment would provide a semblance of regional and religious balance among the Indian members in the Council; he was often on the opposite side of the political fence to Patel; he had been harshly critical of Patel's role and leadership in the 1960 strike; and he appeared moderate and willing to compromise in the interest of the greater good. Patel demurred with the government's proposed choice. On 11 May 1964, he wrote to Sir Derek Jakeway. ${ }^{9}$ Deoki was uncooperative with him and his group, Patel said, and since the proceedings of the Executive Council were of a secret nature, Deoki would get a free hand to disregard him. 'In these circumstances, Mr Deoki's appointment with me on the Executive Council will be tantamount to introducing a split $a b$ initio [from the start] in the Indian representation on the Council and thereby weaken the position of Indians vis-a-vis the Fijians and the Europeans. If I am to join the government I should be sure of fullest cooperation at least from my Indian colleagues in the team and in this respect I can only be sure of Mr Madhavan and not Mr Deoki.' Deoki's selection would make little difference to the existing splits in the Indian community, Patel agreed, but he told Jakeway that if 'for some reason you decide to appoint Mr Deoki, I hope you will appreciate my difficulty and understand if I prefer to remain out of the government.' Jakeway regretted Patel's decision, he said in a handwritten

9 Patel's letter and Jakeway's reply are in Patel's private papers. 
note on 30 May, but there was very little else he could do other than appoint Madhavan to the Executive Council. Deoki's political career was effectively over; he would lose the next election.

Under the membership system, the Executive Council continued to advise the Governor who decided all matters of policy. But the one important change was the assumption of collective responsibility by members of the Executive Council for the formulation and implementation of government policy. Those unable to accept the principle of collective responsibility would have to resign and be replaced by other unofficial members. All three members had direct access to the Governor, and each had a Secretary [equivalent to today's Permanent Secretary] who was in charge of the office and served as the link between the Member and the departments which came under him. Heads of departments retained full internal control of their departments, responsible to the Colonial Secretary in matters pertaining to the civil service, answerable to the Member for functional operations and to the Financial Secretary for all matters of financial administration. Patel's secretary was Kenneth Bain, an experienced civil servant who had previously served in Tonga and who would later join the Commonwealth Secretariat in London.

Along with Ratu Mara, Patel agreed to serve full-time on a salary of £3,000 a year, with a $£ 75$ monthly housing allowance, and a $£ 275$ annual constituency allowance to meet subsistence, transport and associated costs. Falvey opted for part-time appointment. Patel relocated to Suva. Patel's appointment was not surprising; it was simply an acknowledgment by the government of his leadership of the Indian community. His supporters felt proud that their leader was now sitting in the highest echelons of the government, helping formulate policy. The Fiji Samachar welcomed the membership system as 'the first step towards the road to independence. It should be maintained firmly. ${ }^{10}$ But others disagreed, and criticised Patel for accepting the position in the Executive Council. Among the critics was Kisan Mitra, the mouthpiece of Kisan Sangh, which said that Patel 'who has never done any good to the Indians and he does not intend to do so,' has become a government servant. 'Servants will have to obey their employers. This is the set rule of the world. What can the Indians expect from a government servant for their welfare?'11 Jai Fiji castigated Patel for accepting such a large salary without consulting his constituents. ${ }^{12}$ This was yet another evidence of his greed.

Patel condemned the two weeklies for their criticism. Invoking religious imagery, he said that in Ram Rajya, there was one dhobi (washerman), who could

10 Fiji Samachar, 28 May 1964.

11 Kisan Mitra, 3 June 1964.

12 Jai Fiji, 7 January 1965. 
not refrain from condemning a noble woman like Sita. It was not surprising that in this age (Kaliyug), there were two dhobis, and both of them found in Lautoka, the home of the two dailies. Anyone familiar with the law knows that according to the existing constitution no Indian in government employment can become a representative of the government in the Legislative Council. In the circumstances, if I was a government servant, I could not have become an elected representative of the people. I am a member of the government on behalf of the Indian community, not a servant..'13 The membership system was to be welcomed as a step in the right direction, Patel said. 'Today people have a say in government whereas before government had deaf ears. Now the views of the people are being considered.' 'Once we establish mutual confidence and trust amongst all groups in this House, and amongst all communities outside this House, I think the field will be cleared and we all will be in a position to make advances freely and firmly.' Financially, it was a sacrifice for him to join government. Three thousand pounds may appear a lot of money to some people, he said, but that would be no more than the fee for four court cases for him. In any case, he was not in the Legislative Council when the salary was decided by the members. The issue never came up again.

A.D. Patel was the Member for Social Services for two years. Those who worked closely with him found him courteous, astute and judicious, and developed a genuine affection for him. Aubrey Parke, sometime Secretary of Social Services, remembered him as a 'wonderful and kindly man to work for in the office, a cheerful and thoughtful travelling companion and a friendly neighbour who never minded what time of day or night I called on him. ${ }^{14}$ This view was echoed by others who had close contact with Patel. Among them was J.G. Rodger, the long-time Director of Education in Fiji. He found Patel refreshingly different from others with whom he had worked during his long career. Rodger's recollection provides an intimate first-hand account of Patel's method of work. ${ }^{15}$ He said:

A.D. differed from his successors in two main ways. First, he had (or at least gave the impression of having) no political axes to grind. This meant he was able to look at educational ideas and problems in terms of education not in terms of votes; and because we (his senior staff in the Education Department) had been brought up to do likewise there was in fact very little friction between us. Indeed, I doubt whether we really appreciated at the time just what an introduction to the future 'ministerial system' A.D. was in fact giving us. Certainly, after he left, we initially found it very difficult to get into the habit of judging possible

13 Jagriti, 5 January 1965.

14 This letter is in Patel's private papers.

15 Personal communication. 
changes in terms of political expediency - though it is surprising (or would depressing be the better word?) just how quickly we did get used to it.

The second difference related to Patel's approach to the issue of financial responsibility. As civil servants, Rodger and his senior staff had to take financial constraints into account when making major policy decisions. 'But A.D.surprisingly, because he was a very intelligent man - seemed to regard this as a very negative and 'colonial' approach. If funds were not available for something he wanted done, there were, in his view, three obvious approaches: increase general revenue by increased taxes, etc; increase his ministry's budget at the expense of someone else's; or rob one part of the Education Department to pay another. He never got far with the first two, so the pressure was constantly on us to see if the third could be made to work - 'getting our priorities straight,' was how A.D. put it.' Often Rodger and his senior staff had to decline Patel's proposed changes in priorities. 'But there is no doubt that once we started looking at things through his eyes - he was a very persuasive teacher! - our generally negative attitude became positive.' Rodger goes on:

Here's an example of the way he learned to handle us. He phoned me well before 8 one morning to ask that Max Bay (my Deputy) and I come along at morning teatime and tell me why I can't do so-and-so ('so-andso' being his latest bright idea). It was the first time he'd used this ploy and it proved very effective, because a hurriedly-convened staff meeting at $8 \mathrm{am}$ had shown me that the idea wasn't in fact nearly as impracticable as it had sounded 20 minutes earlier. When I subsequently told him how near I'd been to saying 'no' again, he smiled engagingly and said, in the nicest possible way, 'You know, Gordon, it's good for all of us to be made to think sometimes.'

Education was certainly a major interest of Patel's, as we shall see, but there were others as well. Patel was instrumental in setting up a number of projects which still exist today. D.P. Hurley, the chairman of the Housing Authority, wrote that Patel was 'involved in much of the Housing Authority's planning and operations and was the key-man in our negotiations with the Government of that time. ${ }^{16}$

The low-cost housing which the Authority provided in Raiwaqa and elsewhere since the mid-1960s is a permanent fixture of urban development in Fiji. The prison system was constituted as a separate Prisons Service in line with other disciplined services, like the police force, and placed under the Controller of Prisons, with other senior officers appointed directly by the Governor. While

16 The letter is in Patel's private papers. 
prisons 'punished' offenders, Patel said his ministry laid 'great importance on the reformative side of the prisons.' To that end, the teaching of trades and skills was important and was to be encouraged. The Library Services of Fiji was started, and the Western Regional Library established (and opened by Patel on 20 November 1964), with branches set up at Ba, Nadi and Sigatoka. Books were also taken regularly to the islands of Viwa, Malolo and Vatulele as part of the Book Box Scheme funded by the British Council. As we know from the previous chapter, libraries and books were things that mattered greatly to Patel. These libraries still exist today. A 'Fair Rents Bill' was approved to control excessive rents charged for houses in urban areas.

A landmark body created during Patel's tenure as Member for Social Services was the Fiji National Provident Fund, based on a report prepared by J.E. Ashford. ${ }^{17}$ Patel shepherded the report and the Bill through the Legislative Council. The Ashford report concluded that among the causes of poverty in Fiji were old age, widowhood, desertion or imprisonment of the breadwinner, unemployment or permanent incapacity caused by injury and sickness. The Fund would be a compulsory savings scheme for wage earners who would make periodic contributions through deductions from their wages, at one shilling per every pound earned, with matching contributions from employers. Funds would accumulate for each member until he or she reached retiring age, or it could be withdrawn because of some contingency, as such as death of the member, permanent incapacitation, emigration or marriage (in the case of women). The Fund would not only provide social security, but also act as stimulus to growth through local savings. The Fiji Industrial Workers Congress supported the measure and led a delegation to Patel. James Madhavan noted for the record Patel's own commitment to the idea of social security. He had advocated some form of social security in the mid-1940s; now, twenty years later, his vision was being realised. This was 'by no means a small achievement,' Madhavan said. 'It is a great achievement for him and for all those who think in terms of social welfare and old-age benefits and who fight against destitution of the workers of this country who have always been living hand to mouth.'

But the Fund had its critics too. The Kisan Mitra criticised Patel for pushing the legislation that established the Fund.$^{18}$ It said that the compulsory savings of one shilling per every pound earned was too excessive for the ordinary wage earner! C.P. Singh, nominated Indian member of the Legislative Council, also rejected the proposal. The workers were already struggling: how could they be expected to make contributions to the Fund without incurring further hardships? 'It is better to have a loaf of bread now, than to have half a loaf and

17 Debated in the Legislative Council in March 1965. A Destitute Allowance scheme was started in the 1950s for the Indo-Fijian community.

18 Kisan Mitra, 7 April 1965. 
prepare for the future.' Andrew Deoki shared those sentiments. Just because a similar Fund had been established in other British colonies did not guarantee its success in Fiji. 'Our economic conditions here in Fiji are such that we cannot say that a scheme of this nature would be successful.' He wondered how would the Workers' Congress contribute five shillings of their wages when they said they could not pay a Basic Tax of six pennies in the pound. Patel was scathing in his reply: 'Any person with an iota of sense can see the difference between payments straight-out as a tax of $6 \mathrm{~d}$ in the pound and saving for a rainy day which attaches a matching contribution from an employer, which earns interest, and which gets exemption from income tax.'

As the Member for Social Services, Patel said his task was to improve the standard of living of people. Integrated development, of both human and natural resources in tandem, was the right way forward. A good standard of living meant good income, good health and good education for every citizen. If development did not reduce and wipe out poverty, ignorance and disease in an underdeveloped country like Fiji, then the development plan would fail to serve its purpose. Poverty, ignorance and disease were the three enemies of mankind, always working in concert. Poverty bred ignorance as well as disease; ignorance brought about poverty and helped disease; disease led to poverty as well as ignorance. 'So in any development plan we have got to attack from all sides, not only physical development of the natural resources of the colony but also the development of the human element, the man power, which is the most important component of any development plan.' Finance was critical, but not all important in the scheme. 'Development is for man, man is not for development, and what I wish to say is that health and education are not mere social graces and declarations.' They were important economic investments and it was, therefore, wrong to treat education and health as subjects separate and apart from economic development. 'I know that there is a mistaken notion amongst many people in this colony, but the time has come when this sort of disillusionment [sic] should be done away with.'

'Education has got to look ahead,' Patel said; it should 'precede and not keep pace with, or follow, economic development in this colony.' Proper education was the key which opened the right doors to a bright future, but what kind of education was appropriate for Fiji? Education is always a contentious issue, a subject of perennial debate in every society. But in Fiji, there were several issues that aroused particular interest. One was the medium of instruction in schools. Many parents, particularly in the Indian community, preferred English as the medium of instruction in primary and secondary schools, and criticised the government for not doing enough to lift the standard of the language. English was the ladder to success in colonial society, and the sooner the children acquired it the better. 
Patel differed. He argued his case this way: 'As far as Indians and Fijians are concerned, English is a foreign language. We should also bear in mind that in most of the areas in this colony, the only language spoken is either Hindi or Fijian...you might teach the children all the elementaries of the English language, but as soon as he goes out of the school, he has, of necessity, to give up English for the time being and use the Hindi language. The same thing happens in predominantly Fijian areas.. .It is only in urban areas, townships, the town of Lautoka and the city of Suva where all the races are thrown together, that English becomes the important language (but not so important as to exclude the other two languages) in daily use. So we have to realise the circumstances, the linguistic setup in which we are trying to teach English to our children.'

Another factor to be considered was that Fijian or Hindi, or any other Indian language for that matter, was an integral part of the culture of the people. The Fijians would not be prepared to give up their culture, nor the Indian theirs. Consequently, though they would all like to learn English, they would not like to learn by sacrificing their own language. 'Just imagine expecting Fijians to perform their traditional ceremonies in the English language instead of the Fijian language. It would lose all charm and meaning. So we have to got to remember that while we want to improve English in this country, we do not want to sacrifice other languages - the languages which are the vernacular languages of the culture of the people.' English afforded people 'a window on the world,' and the standard of English needed to be improved, but not at any cost. Language of instruction was an issue on which opinion was deeply divided, but Patel's position was consistent with the stand he had taken on the issue since the 1930s: loss of language would erode the foundations of a culture.

The integration of schools was another issue that aroused considerable emotion in the colony. Some groups, Europeans especially, preferred racially segregated schools for obvious reasons. There were others who preferred multiracial schools. 'I do not like the word multi-racial because it emphasises and accentuates racialism. I would rather like to call them public schools, or call them national schools or, if you like, non-racial schools. I would like to see (and I staunchly believe) all the children in this colony, irrespective of race, or creed, being able to attend the nearest school that they can go to.' To that end, the Director of Education, in consultation with Education Advisory Councils, was authorised to close schools in certain areas to reduce fragmentation, duplication of effort, unnecessary competition, and communal segregation. 'I know that the time has come when we have to make up our minds...this is the time when we must decide; either we integrate or we disintegrate - there is no third choice.' There was still a long way to go, Patel admitted. For example, in government schools, such as the Suva Grammar School, the Director of Education was empowered to give priority to candidates of the race which was predominant on the roll of 
the school, but he could, at his discretion, admit pupils of other races. And in government-aided schools, preference could be given to pupils of a particular race or creed, but no pupil could be denied admission solely on those grounds. That was the present reality, but Patel said that he was 'rather optimistic of persuading the people who control these institutions to broaden their views and accommodate children of all creeds as far as possible.' Patel's own daughter, Vasantika, was one of the first Indian children to be admitted to the Suva Grammar School. That proved that there was integration in schools in Fiji already, chimed in John Falvey. 'But one swan does not a summer make,' retorted Patel. Nonetheless, as the 1960s progressed, more non-European children entered the formerly exclusively European schools.

Early in January 1965, Patel convened a meeting of all non-government primary school managers at the Suva Town Hall to discuss removing race from names of schools (such as, say, Ba Fijian School or Nadi Indian School). The Fijian managers objected. They had their own government, they said, referring to the Fijian Affairs Board, and Patel should discuss policy matters with that body. The motion to have non-racial names for schools was defeated 90 to 73 . The Fijian people at large strongly opposed Patel's suggestions of non-racial education. Said S. Saratibau of Tamavua: 'I have two reasons. Firstly our language and secondly our custom. We are going to lose both of them if this suggestion is carried out. It will not happen immediately but it will become obsolete gradually.' S. Dewa of Sewani-Serea thought that Patel's intended but unstated policy was 'to dissolve our most sacred institutions: our customs, our language, our way of life. ${ }^{\prime 19}$

Patel was undeterred. Opening the 34th annual conference of the Fiji Teachers Union in August 1964 at the Majestic Theatre in Labasa, he urged the predominantly Indian members of the FTU to seek ways of joining hands with the Fijian Teachers Association, which was exclusively Fijian. ${ }^{20}$ 'If the main profession, which is the teacher of all professions, if that is going to be divided and separated along racial lines, then where is the hope of eradicating racialism from the Colony?' he asked. 'Won't it be better if we thought less of our race and more of our nationality?' To those who felt that racial barriers could not be broken down, that there was something immutable about communal affinities, Patel responded in his own quintessential way at the Century Theatre in April 1965. ${ }^{21}$ 'If a young calf is kept by itself in a separate paddock for the first six months, when it is put in another paddock with other calves, it will try to break the fence and run back to its old paddock. In the same way, after ninety years of British rule in which Fijians and Indians have been kept separate, attempts are

19 Nai Lalakai, 28 January 1965.

20 Pacific Review, 9 September 1964.

21 Jagriti, 8 April 1964. 
now being made to bring them together. This is a matter which stuns people. They will not easily leave the paddock which they are used to. The object [should be] to breakdown the barriers and bring everyone into one paddock. ${ }^{22}$

Teachers had a vital role to play in that process cross-cultural bridge building, Patel said. And he urged them to constantly upgrade their qualifications through training.

Teachers needed to have pride in their profession. Addressing the 30th annual meeting of the Fijian Teachers Association, he said: 'You might encourage your members to prepare short talks, and the reviewing, criticism and discussion of them, as part of the ordinary everyday professional responsibilities. You should not regard this as the kind of activity which belongs only to research by lecturers and specialists. The professional status of your organisation will grow in proportion to the increased professional knowledge and ability of your members in the eyes of the general public as well as in the classroom. You should lose no opportunity in becoming leaders of educational thinking, development and progress in Fiji. The success of the teacher depends on the status of his profession in society. The full status of teachers will be achieved when every teacher is immensely proud of his calling. Proud, not boastful. Getting quiet satisfaction from being able to follow his calling. When every teacher is proud to teach, we won't hear so much about the status of the teacher. ${ }^{23}$

Patel also spoke of the need for a university in Fiji. There were many who thought this idea Utopian, expensive, unnecessary and premature. Among them was Andrew Deoki, who asked if it was right to have a university in Fiji when the government could not properly provide for the education of thousands of little children of primary school-going age. Wouldn't it be better to continue the existing system of sending students overseas on scholarship for higher education? Would a local university have the same standards as universities in Australia and New Zealand? 'Cater for the little children first and then think of university [education].' Very soon, over 90 per cent of children of school age would be attending primary schools, without compulsion, Patel said. 'Compulsory education, in itself, is not either a great thing or a wise thing.' What Patel wanted was 'universal education, and if parents are sending their children to school without any compulsion, and if the children are going to school out of their own willingness, then we can be proud of the achievement of that at least, the parents of the country are education-minded and sincerely believe in giving education to their children.' In such circumstances, making education compulsory would be redundant.

22 Jagriti, 8 April 1965.

23 Manuscript of the speech in Patel's private papers. 
As for standards, the proposed university, he said, would be second to none, comparable in quality to universities not only in Australia and New Zealand but to those in the United Kingdom and the United States. Sending select students abroad for higher education had its own difficulties, Patel went on: 'All children who are fit for academic or technical education will not be able to go abroad. If the government is going to send students abroad to receive higher education, it will only be a limited number. There would be students here who will not have sufficient means to go abroad to receive higher education. There would be students here whose parents would not be willing to send them out into the world in alien societies, for religious or social reasons. Sometimes students who had the qualifications were refused sponsorship simply because it was thought that they lacked the standard necessary for success in New Zealand. Having university education available locally would resolve that difficulty. 'Our problem is that many students go abroad, receive higher education, receive qualifications and then settle down outside of Fiji because they get more remunerative employment. We at present, unfortunately, are placed in such a position that our educated people have to seek employment abroad and we have to get people from other countries to fill our posts in Fiji. If we have a university here, that problem would, to a large extent, be solved. Most of the graduates, or sub-graduates that we turn out here will be looking for local employment and will fulfil local needs.' The case for a university based in Fiji needed no further elaboration.

Patel had been talking about starting a university in Fiji in the 1950s, as we have already seen. He had once raised the idea with the Government of India which had responded enthusiastically to the proposal with promises of financial and personnel support, but nothing came of it. Still, both he and Swami Rudrananda had managed, with the assistance of the Ramakrishna Mission, to start a University Tutorial College at Tailevu in May 1965. Its aim initially was to prepare students for pre-university courses - Ordinary and Advanced Levelsof the University of London and then to full-fledged undergraduate education in the Humanities, Sciences and Letters. It was an ambitious project and the idea withered away on the vine of public indifference and financial constraints, but by then the idea of a full-fledged university in Fiji was no longer a distant hope. The Higher Education Mission arrived in 1965 under the chairmanship of Sir Charles Morris, former Vice-Chancellor of Leeds University and Vice-Chairman of the International University Council for Higher Education Overseas. Its recommendation for a regional university was realised when the University of the South Pacific enrolled its first students at the former Royal New Zealand Air Force Base at Laucala Bay in Suva in February 1968. That event marks one of the most important turning points not only in Fijian but in wider Pacific islands history in the twentieth century. 
There were areas and issues outside Patel's portfolio on which he spoke, and it would be tedious to repeat all of them here. However, there was one, the question of land, on which his thoughts are important. Land was one of the most contentious issues in Fiji in the post-war period, as it is still today. The creation of the Native Land Trust Board in 1940 had brought about a semblance of regularity in leasing arrangements, but for the tenants it had created new uncertainties. One of them was the reserves policy intended to protect the interests of the indigenous land owners by ensuring that 'ample land suitable for their use, maintenance or support is reserved having due regard to the natural economic development of the natives.' Large areas previously occupied by Indian tenants were placed under reserves, with the farmers moved to new and sometimes inaccessible, arid, virgin areas. Tenants wanted security and firmer protection of the law. Their anger and hurt was accentuated by the sight of their previous land falling into disuse. Patel was acutely aware of the tenants' anxiety, and their helplessness as well. In November 1964, he told a meeting of Indian farmers: 'Indians depended on agriculture, and without land, cultivation could not be carried on. We would remain landless even after the granting of independence; we would always remain tenants of others. The government would say to us: 'You have full rights in Fiji but under the Constitution, after the expiry of leases, the Fijians, if they wish, will give new leases and if they don't, they will not give them. It is their pleasure. The land is theirs.' On the other side, Fijian landlords wanted more secure returns and, over time, the opportunity to cultivate their lands themselves, which they found almost impossible to do under the existing system. They objected vehemently to the practice of their land being perpetually leased out, often without their consent.

In July 1966, the government introduced the Agricultural Landlord and Tenant Bill in the Legislative Council. ${ }^{24}$ The problem of land was succinctly summed up by the committee, chaired by the Attorney General, upon whose recommendations the Bill was based. The Committee was concerned to protect the agricultural tenants against exploitation through exorbitant rents and premiums, the threat of eviction at the whim of landlords and the constant anxiety about the future caused by the insecurity of tenure. It was this fear and sense of insecurity which discouraged the tenants from investing in the land or in building proper houses or installing other agricultural fixtures. There was every incentive for the tenant to 'mine' the land in the quickest possible time because there was no guarantee of long-term occupation. The Bill proposed that contracts taken out prior to the enactment of the ALTO [Agricultural Landlord and Tenants Ordinance] legislation be extended automatically at the option of the tenants except where the land had already fallen into reserves or where the tenant had shown bad husbandry. All existing leases should be extended by two ten year periods and

24 Legislative Council Debate, 20 July 1966. 
a fair market rent assessed every five years. Annual tenancies were abolished along with tenancies-at-will (whereby tenants had to pay monthly rent while their application for extension of their lease was being considered), and which could take as long as a year to be processed. Share-farming was controlled, and while tenants could not receive compensation for improvements they had made, they at least now enjoyed the security of two extensions. Patel's proposal to the Committee for perpetual tenancy was rejected, but that was not surprising.

The Bill provoked a very heated debate in the Legislative Council. Patel supported it in the end, with, as he said, 'a feeling of ambivalence.' It did not provide the tenants with the security he would have liked, but it was an improvement. The Bill had bought time. 'We are not finding a permanent solution to the problem but we are, by this Bill, providing an immediate relief and remedy which may last for twenty years and within those twenty years this country, I hope, will make great advances in economic development which will result in relieving pressure on the land and increasing the prosperity of the country, which will result in increasing the number of tenants of all races, including the Fijians, so that at the time when it comes to revise our thinking and to find a solution, there will be as strong and as numerous a body of Fijian tenants as there are of Indian tenants now.' This would help in securing a solution, or at least remove race from the equation.

Fijians should be encouraged to enter commercial cultivation, Patel said, but he warned against over-optimism. If the Fijian landlords gave in to the temptation to re-possess land already in a good state of production, it will only result in uprooting farmers who have been experienced over all these years, farmers who have specialised in growing particular crops which they are growing on those lands, such farmers of necessity will face utter ruin and the land which will revert to the Fijian owners will, of necessity, go down in production.' Meanwhile, the uprooted farmers - Patel called them nomadic farmers - would be removed to virgin or marginal land, and would have to start all over again. 'That sort of treatment will terribly shake the confidence of the farmers both as far as their own personal interests and their profession is concerned, and also in the training of the future generations.'

Fijian appetite for commercial competition was whetted by the prospect of prosperity in the sugar industry. That was understandable, Patel argued, but shouldn't the already large areas placed in reserves be used first before displacing the Indian tenants from their leases? Prospects in the sugar industry looked attractive, but there were dangers as well. The industry had had its ups and downs and there was no guarantee that this would not happen again. Indian farmers had time and again rescued the industry from ruin. 'It was because of their innate temperament for hard work and thrift [that they succeeded]. They know how to live on as little as they can get as well as live on the utmost 
limits of luxury and comfort that they can afford.' There was enough room for expansion in the sugar industry to accommodate Fijian growers, but that could be done without displacing the existing Indian tenants.

As to be expected, the Agricultural Landlord and Tenant debate aroused strong interest and heated exchanges. Semesa Sikivou, at the peak of his powers and an acknowledged champion of Fijian rights and aspirations, attacked Patel in terms that could be constituted unparliamentary. Patel reminded him of rats who would sneak into his smelly socks at Vulagei during the Second World War. 'Rats would sneak in and blow gently, take a little bite, then blow and take another bite, taking something out of you and yet covering up afterwards, soothing, soothing, soothing, as it bit. Patel reminded me of that.' Patel, Sikivou said, was an acrobat, full of tricks. He was referring to Patel's performance in the debate. At one moment, Patel seemed to be supporting the Bill, albeit half-heartedly, while in the next breath, he excoriated it. He was a member of government, and yet he was critical of it. Sikivou was frustrated, angry and perplexed. It was the crafty Patel at work again. Referring indirectly to Patel, Sikivou said: 'Perhaps many people do not realise that certain people in this country have only got to put up a suggestion and others rally round and tell them the answer is 'No, this must be no good'. Patel had that kind of effect on his opponents. But this was not the last time that land would come up for discussion. The Bill was approved but it remained in limbo because the Membership System was dissolved and the ministerial system of government introduced following the promulgation of a new constitution in 1967. At the time of his death in 1969, Patel was a member of the newly constituted Agricultural Landlord and Tenant Committee, chaired by Ian Thompson.

Semesa Sikivou's criticism of Patel revealed an important tension inherent in the Membership system. Patel was an elected member with responsibility to his party and his constituency and yet at the same time he was bound by the rules and procedures of collective responsibility as a member of government. This placed Patel in a difficult position. For the most part, though, the system worked well, not least because there was a genuine desire on all sides to make it succeed. It required considerable astuteness and dexterity on the part of the Members, particularly Patel, who stood for interests and groups which had much to gain from change. In other circumstances, Patel might well have opposed the Landlord and Tenant Bill, but as a Member, he supported its provisions while clearly indicating his concern about broader issues, such as the government's reserves policy. By the time Patel finished his speech in the Legislative Council, there was no doubt in anyone's mind where he stood.

The Members also used surrogates to make their points in debates in which they themselves might have found it too sensitive or difficult to participate. For Patel, Koya provided the perfect proxy. While Patel sat on the official benches, 
Koya became the crusading, uncompromising champion of Indian rights, a takeno-hostages kind of performer in Council debates. He criticised Bills, opposed motions, took on the opposition. Chirag Ali Shah and James Madhavan also made their contribution, but in a much more restrained, moderate way. Koya played the same role for Patel that Sikivou played for Ratu Mara who adopted a measured, statesman like approach, above the fray of ordinary politicking. Sikivou, on the other hand, seemed to be the very opposite, an uncompromising champion of Fijian nationalism, quick on his feet, disruptive in debate, baiting the opposition with his barbed interjections and cutting remarks. Only he could call Patel a rat, a duplicitous dealer, and get away with it, such was his reputation (or otherwise) as a debater in the Council.

Sometimes, the Members avoided complicated issues which could compromise their political credibility or undermine their public positions, by submitting separate minority reports. A case in point for Patel was the Report of the Fiscal Review Committee. ${ }^{25} \mathrm{He}$ was a member of the nine-member committee, along with Ratu Mara. He had been appointed shortly before being made the Member for Social Services. The Fiscal Review Committee, as the name suggests, was asked to review the financial position of Fiji, and to recommend ways of increasing the colony's revenue. It made several far-reaching recommendations, among them the imposition of the Basic Tax on all wage earners of the colony at the rate of 6 pennies per pound earned. Patel objected. He wrote: 'It is grossly iniquitous because it does not take into consideration the taxable capacity of the income earner and the incidence falls heaviest on those who are least able to bear it. There are thousands of Fijians, Indians and part-Europeans who live just on the breadline or even under that line. As it is, these people find it hard to meet the school fees for their children. A basic tax of this nature will further increase their inability to pay school fees for their children, and in many cases it would result in further privation and suffering in poorer families.'

Patel was attacked by Semesa Sikivou, among others, for dissenting, and was asked to resign for breaching the collective responsibility principle of the membership system of government. Patel dismissed such attacks. He was selected to serve on the Committee in his individual capacity, not in his official capacity as the Member of Social Services. He had given the government his candid advice. It was for the government to decide whether to accept or reject that advice; no fiscal measure had yet been formulated. It would be wrong for himself or any other member of the Committee to 'insist that every word that they have recommended must be accepted by the Government,' and to threaten resignation if a compromise policy were adopted. 'It must be remembered that we are the Members of what I call a conglomerate government. We all represent different conflicting interests; we have got to harmonise these interests; we have 
got to make compromises day to day if we [are to] make such a government function.' It was not an easy task to accomplish. It was easier to be a sectional politician than a statesman in such a government. But Patel went on, 'A statesman has got to look to the next generation. A politician usually looks to the next election.' The question of resigning was for his conscience to decide. 'The day my conscience tells me that I am no use to my country by occupying this seat on the Government I will vacate it without hesitation.'

There were times when Patel was sorely tempted to resign. The coverage of confidential discussions surrounding the 1965 constitutional conference by the Fiji Broadcasting Commission had so vexed Patel that he wrote to the Governor in April 1965 complaining about distortions and, as he saw them, outright lies about himself and his party's position on important issues. In one of his speeches Patel said that he was an 'optimist' and an 'economist' (why use three words when two will do). The public heard that Patel had claimed himself to be an 'opportunist' and a 'communist'! Patel said he found it very difficult to be a member of a government that condoned such behaviour in one of its own departments. The correct procedure, Governor Jakeway told Patel, was to refer any instances of mis-conduct or negligence for investigation to the Colonial Secretary or to the Broadcasting Commission itself. Jakeway reminded Patel that membership of Executive Council involved participation in the Government; it did not stifle criticism of Government, its officers or statutory bodies but it did imply directing such criticism through appropriate channels. A member could not enjoy the advantage of operating from the inside and retain all the freedom of being on the outside. Patel could not have it both ways. Jakeway went on:

I value your membership of Executive Council and believe it to be in the national interest that you should continue to be a member and to retain your portfolio. I realise that this from time to time presents you with a conflict of loyalties, and I have hitherto much admired the way in which you have reconciled that conflict. At this juncture, in particular, it would be a setback to the ideal of national unity for which we are both striving if the leader of the majority Indian party withdrew from the Government. If you share this view I hope you will refrain from active association with words or deeds which make it impossible to reconcile your continuation in the Government with the principle of collective responsibility and the conventions which surround that principle. ${ }^{26}$

The Membership system of government was a transitional phase on the road to full internal self-government. It came to an end in July 1966, when fresh

26 Letter in Patel's private papers. 
elections were held following the London constitutional conference of 1965. In the new Legislative Council, A.D. Patel would become Fiji's first Leader of the Opposition.

The Legislative Council in the 1960s provided a wonderfully vigorous arena for debate and discussion in Fiji. Members defended party positions and deeply held political convictions and issues of particular concern to their respective social and ethnic constituencies. They decided issues and formulated policies which laid the foundations of modern Fiji. These debates remain unparalleled in their intensity, texture and quality. The flair and fluency with which members articulated their views and vision remains unmatched. Perhaps the 1960s was the high water mark for parliamentary debates in Fiji. Much of the discussion in the Legislative Council was taken up with social, economic and political issues that impinged directly on the practical affairs of the colony. Nonetheless, there were a few occasions when the members were called upon to express opinions on issues which transcended parochial and sectional interests, issues which went to the core of some of the basic moral debates about the nature of human society. One such issue in the 1960s was the abolition of the death penalty. Members were freed of their political and official obligations to speak their minds freely. It was, in other words, a 'conscience' debate, and it remains, in my view, one of the finest debates in the annals of the Fiji Legislative Council. ${ }^{27}$

Arguments and evidence were marshalled on both sides. Ratu Mara cited St Thomas Acquinas' principle of natural equity for his opposition to the abolition of capital punishment. The principle held 'that a man should be deprived of the good against which he acts, for he thereby renders himself unworthy of it.' Just because England had abolished the death penalty - which had made the abolition of capital punishment a 'status symbol of civilisation' - did not mean that Fiji had to follow suit. Life sentence was not an effective enough deterrent for murder; 'capital punishment is a real deterrent to taking the life of others and disturbing society.' C.P. Singh agreed, saying that if capital punishment was retained, 'people would be more scared of losing their own lives to take somebody else's life.' Ratu Edward Cakobau also favoured capital punishment. 'I have killed, and I have nearly been killed. If I were to be murdered, I do hope that the man who murders me will be hanged.' Ratu Penaia Ganilau had 'no sympathy whatsoever for any man who has planned to deliberately take away the life of another man.' The murderer deserved the gallows and I would, myself, if I were a murderer, prefer to go that way' Koya agreed: the society was entitled, for its own preservation, to tell a convicted murderer that he had no place in decent human society. 
Equally strongly held views came from those who opposed the death penalty. For once, John Falvey, Semesa Sikivou, Andrew Deoki and A.D. Patel were on the same side in a debate! Patel reminded the members that two decades before, he had opposed the death penalty but then his had been a lone voice in the wilderness. He opposed the death penalty because 'non-violence and non-killing is the very essence of my upbringing' as a Hindu. He was taught that life is sacred and that 'it must not be taken under any circumstances.' An eye for an eye and a tooth for a tooth was no answer, Patel said. He held his eyesight precious, and if a man offered him the alternative of losing his life or his eyesight, he would opt for the former. 'But if he puts my eye out, he will be sentenced to imprisonment; his eyes will not be put out by the State. If a man burns my house, I cannot ask the government to burn his house.' So it was not a simple question of punishment being the same in nature as the crime. 'We have got to find adequate and proper punishment for the person who has committed the offence and, at the same time will deter others from committing such a crime.'

To the argument that some murders - of a policemen in the discharge of his or her duty, for example - were more serious than others and thus deserved a higher penalty, Patel responded this way. People in public life were all taking risks: the magistrate, the judge, the counsel defending a criminal. 'Now, supposing a man who has been sent to gaol by the magistrate, after he has served his sentence, feels very annoyed with the magistrate for sending him to gaol, comes back and murders the magistrate. Is that any less serious than if he kills the policemen?' Killing a policemen would lead to anarchy, and threaten the entire foundation of society, argued those who favoured capital punishment. But to Patel, 'any murder is an act of anarchy.' 'Why should a man who, for instance, murders a Governor be liable to imprisonment for life and a man who murders a constable be hanged?'

Patel exposed the same sort of tenuous logic in the view that held that prisoners committing murder should be sent to the gallows. 'Supposing a man has committed some petty offence and he has been sentenced to gaol for six months and he has been ordered to serve his sentence extramurally, and while he is a prisoner serving his extramural sentence, murders somebody with whom he has a private grudge. Why should he be hanged just because at that time he happened to be a prisoner serving an extramural sentence. If he had committed the same murder before he was prisoner or after he had served his imprisonment what serious difference does it make to the heinousness of his crime, to the gravity of the crime?'

Capital punishment had not, and never had been, a complete and universal deterrent, Patel went on. Murders were committed in countries in spite of the provision of capital punishment. 'Merely providing for a deterrent has never 
kept the prisons empty or the country free of crime. If it were so, then we would not need an efficient Police Force. All that we have to do is to enact laws providing for these sentences, people would be simply frightened of the sentences and would desist from committing crimes. But that does not happen.' Fiji had a very high murder and suicide rate during indenture, one of the highest among Indian indentured labour importing colonies; death penalty had not acted as a deterrent. But both declined dramatically after indenture as social conditions improved. Murders, like so many other social problems, had their root in 'maladjustment of human relationships,' and in poverty. People did not kill each other just for the fun of it, as sometimes happened in western countries, Patel argued. 'We are, on the whole, a better behaved community.'

Patel then referred to an incident that Ratu Mara had used to justify his support for the retention of capital punishment. As a young man growing up in Lakeba, Mara had been deeply distressed by the murder of a Chinese storekeeper, the only murder to have taken place on the island. It was the fear of capital punishment that had acted as real deterrent to murder and mayhem in the distant islands in the Koro Sea. Patel turned Mara's evidence on its head. The fact that in all these years only one murder had taken place in Lakeba, where police presence was minimal, spoke not in favour of the death sentence, but in favour of the 'natural peaceful disposition of the people of the country and good human feelings prevailing there.' As long as those good relations remained, and cases of maladjustment reduced, there was every reason to expect a corresponding reduction in the crime rate. The abolition of the death penalty was a humanitarian gesture, Patel concluded. It was wise to extend that gesture both to the victims as well as to prospective murderers. He alluded to his experience as the lawyer who had defended the largest number of murder cases in the colony. In all those years he had never come across a person who did not have the potential for good in him. Men had been driven to murder for various reasons, but they were not brutes. The death sentence would not do anyone any good. Instead, he pleaded for the life sentence which, he hoped, 'will be used in touching his humanity so that he becomes again, a decent, normal human being.' The death penalty was suspended and abolished altogether a decade later. 



\title{
Chapter 9: Shaking the Foundations
}

\begin{abstract}
Of all the people, Indians are bitterly against communal representations because they have seen its painful results in the course of time. It may not be very serious now, but as time goes on, once people get used to the idea of racial separation, racial attitudes harden and people start thinking in racial terms and racial interests which leads not to one nation but, in the course of political developments, it leads to claims of several nations.
\end{abstract}

A.D. Patel, 1965

Political liberty, equality and fraternity rank foremost among the good things of life and mankind all over the world cherishes and holds these ideals close to its heart. The people of Fiji are no exception.

A.D. Patel, 1965

'In ten years time, there will be a lot of changes in this country,' A.D. Patel said to Andrew Deoki in 1960. Deoki looked at Patel and asked, 'What do you mean? Do you mean that you will be the dictator of this Colony in ten years time?' Deoki went onto recall the rest of the conversation: 'And he looked at me and smiled, and he said 'Yes.' 'In other words,' Deoki informed his listeners, 'he wants to be a dictator.' ${ }^{1}$ C.P. Singh, another opponent and a nominated Indian member of the Legislative Council, called Patel an evil demigod, like Ravana, a man endowed with the intelligence of ten humans, but who always used it for destructive purposes. To his supporters, on the other hand, Patel was like a medical doctor whose diagnosis one never questioned and whose prescriptions one accepted unreservedly. Clearly, Patel aroused strong emotions on all sides. He only had to put up an idea, Semesa Sikivou once said, for Patel's opponents to close ranks and oppose it. Whether one supported or opposed him, one could not discount Patel's presence and influence as a political leader. He was the founding father of the independence struggle in the colony. Here we explore the ideas and strategies he employed in that struggle.

By the early 1960s, as discussed in the previous chapter, Britain had already begun introducing a measure of self-government in Fiji, the membership system being the first step in that direction. Everyone acknowledged the inevitability of some form of self-government, but disagreed on its pace and direction. Europeans opposed any constitutional change which might diminish their dominant position in the colony. But they also realised that alone, they could not

1 Legislative Council Debate, September 1965. 
justify their privileged constitutional position. So they began forging a closer alliance with the Fijians. For their part, the Fijian people, too, opposed farreaching constitutional changes. As Ratu Mara told the London constitutional conference in 1965, the Fijian people 'had declared that independence is not our goal because we have never found any sound or valid reason to attenuate, let alone abandon, our historical and happy association with the United Kingdom.'2

His ambivalence and apprehension were understandable, for the early 1960s was a deeply uncertain time for the Fijian people. Two independent commissions of enquiry had both recommended far reaching changes in the structure of the Fijian Administration, which caused great alarm in the Fijian community. In 1959, Professor O.H.K. Spate of the Australian National University was asked to examine the extent to which the social structure of the Fijian people inhibited their economic prospects and potential, and to suggest appropriate remedies. Spate did not mince words in his report. The Fijian people were lagging behind the other communities in economic development; the inherent conflict between custom and money was 'at the root of the problem'; and chiefly leadership, attuned to the needs and requirements of another era, was unable to provide guidance in the changed modern context. ${ }^{3}$ Spate recommended more independence and social and material support for those Fijians who wanted to pursue economic activities on their own.

A year later, an inquiry into the natural resources and population trends by Sir Alan Burns, a former Governor of Nigeria, also suggested drastic changes. ${ }^{4}$ Fijian land ownership should be secure and unchallenged, Burns said, but the reservation of land for exclusive use by the Fijian people themselves should be completed expeditiously to allay the fears of other sections of the community and to pave the way for investment and development; the independent Fijian farmer should be encouraged; the Native Land Trust Board should be placed under the authority of the legislature, and, most controversially, the structure of the Fijian Administration should be modified to bring the Fijian people more into the mainstream of Fiji society. These sentiments were echoed by scholarly enquiries as well. ${ }^{5}$ If the changes the visiting experts recommended were implemented, they would permanently alter the basic fabric of the indigenous society. The fear of the Fijian people was well captured by the Volagauna:

When the wind of change started to blow over us, both the sophisticated and unsophisticated Fijians started looking about them and asking questions on matters quite foreign to their way of life. They think back and visualise what the future has in store for them. They hear so many

2 From the opening statement at the London conference, a copy of which is in my possession.

3 Spate, 1959.

4 Burns, 1960.

5 See among others, Watters, 1969 and Belshaw, 1964. 
things said and foreign influences infiltrate their midst. But what can they do in the weak economic condition they are in? They are hastened or rather pushed forward to a money economy; but when they make their sudden transition, the communal way of life grips them and the two are engaged in a tug of war. They have not been steadily and slowly guided along the correct path and have been neglected for a long time. There are so many words directed at the Fijians, but what can they do? ${ }^{6}$

Such words of anxiety and apprehension, the result of deep soul searching in the Fijian community, would continue to echo throughout the 1960s. But constitutional changes could not be stalled as the winds of change were already evident on the horizon. Western Samoa became independent in 1962, and the Cook Islands in 1965, and it was only a matter of time before the tide of constitutional change would lap the shores of the other Pacific colonies. The Fijian leaders realised this, but insisted that any changes would be acceptable only if they were made with the concurrence of the Fijian leaders and on Fijian terms. To that end, the Fijian Affairs Board, the executive and administrative arm of the Great Council of Chiefs, met on the island of Wakaya in January 1963 and drafted what came to be known as the Wakaya Letter. Mara sent a copy to A.D. Patel in December 1964, hoping that he, Patel, would find it 'digestible.' That letter in time came to be seen as the basic negotiating document of the Fijian people in the 1960s.

Addressed to Nigel Fisher, the Parliamentary Under Secretary of State for the Colonies, the letter reminded the Crown of the special significance of the Deed of Cession for the Fijian people. It was the 'Fijian view that the possibility of severance of this link with the Crown - a link forged in a spirit of mutual trust and goodwill - should never be contemplated.' Before any further constitutional changes were considered, the letter stated, the terms of the special relationship between Britain and Fiji, a relationship similar to that which existed between Britain and the Channel Islands, should be clarified and codified. The letter went on: 'There would have to be a precise restatement of the guarantee on Fijian land ownership. We visualise that the Native Land Trust legislation should not be changed or added to without the prior consent of the Sovereign and the agreement of the Council of Chiefs. We also stand by the expressed desire of the High Chiefs in the preamble to the Deed of Cession that Fiji should be a Christian state and that therefore no constitutional or administrative changes should take place that would deviate from that intention. The provision in the Fijian Affairs Ordinance that all legislation affecting Fijian rights and interests should be referred to the Fijian Affairs Board or, on the recommendation of the Board, to the Council of Chiefs, should be retained, and likewise the Governor's direction

6 Volagauna, 16 October 1964. 
to the Public Service Commission to work towards a balance of the races in the Civil Service.' If these concerns were addressed, the letter concluded, the Fijian chiefs would consider contemplating further constitutional changes. ${ }^{7}$

The letter was a powerful assertion of the principle of Fijian para-mountcy, signed by all five Fijian members of the Legislative Council, including Ratu Mara, Ratu Penaia Ganilau, Semesa Sikivou, Ravuama Vunivalu and Ratu George Cakobau, and by A.C. Reid, Chairman of the Fijian Affairs Board, John Falvey, its Legal Advisor and R.M. Major, the Financial Advisor. The Colonial Office was sympathetic to the concerns raised in the letter but said that any proposed constitutional arrangements would have to take the reality of the situation in the islands into account rather than impose models derived from elsewhere, including the Isle of Man. ${ }^{8}$ Unofficially, the colonial government assured the Fijian leaders that the special position of their people in Fiji as the autochthonous race would be safeguarded. ${ }^{9}$

There is no record of how the Indian leaders viewed the Wakaya Letter; judging by their reaction in Legislative Council debates, it seems very few knew about its existence. Patel knew of its existence and its contents. But from his notes it is clear that he did not accept its preconditions. In a public address at Churchill Park on 24 February 1964 welcoming the new Governor, Sir Derek Jakeway, Patel gave glimpses of his own thinking. ${ }^{10} \mathrm{He}$ spoke of the peace and harmony which existed among the various cultures and ethnic groups in Fiji, which, he said, 'was a good asset to start the building of a nation. He spoke about the economic needs of the Indian community. 'If Indian farmers are provided with sufficient land and facilities for marketing the produce at an economic price, they can play a very important role in the economic development and in raising the standard of living of the people of this Colony.' And he pledged his community's cooperation 'in any measures which may be devised to promote social and political integration and understanding between all the races residing in the Colony.' Phrases such as 'building a nation,' 'political integration,' 'welfare of the people of Fiji.' were the key words in Patel's political lexicon. Jakeway listened politely, but as former Chief Secretary of Sarawak, his sympathies lay with the Fijians. In this, of course, he was no exception. Much of the colonial establishment also felt that way. ${ }^{11}$

\footnotetext{
7 A copy of the letter, though never made public, is available in several places, including the Hansard of the Legislative Council. See also my Broken Waves, 189. The Colonial Office rejected the appropriateness of the Channel Islands as the model for Fiji, the Governor telling the Great Council of Chiefs in September 1963 that 'as the circumstances of these islands are in many respects different from Fiji, their constitutional arrangements could hardly be adopted in their entirety.'

8 Public Relations Press Release, no. 737.

9 Sir Derek Jakeway's statement in the Fiji Times, 2 March, 1965.

10 Address in Patel's private papers.

11 Assistant Colonial Secretary Ray Barker wrote: 'It is probably true to say that most expatriate administrators were at that time pro-Fijian in the sense that we felt in sympathy with their perception of
} 
Patel was aware of the impending constitutional developments. His first priority was to get his own house in order. The Citizens Federation had done well in the 1963 elections, winning all the three Indian communal seats. Soon after the elections, Patel, along with Siddiq Koya and other Indian leaders, decided to transform the Federation into a full fledged political party. From this initiative came the Federation Party in 1963. A formal constitution drafted by Siddiq Koya was adopted on 21 June 1964, making the Federation the first political party in Fiji and among the very first in the whole of the Pacific. The party's founding aim was to create and foster national consciousness 'irrespective of any distinction of community, religion, race or sex;' to bring about economic, social and cultural integration in Fiji by pursuing the ideal of 'Unity in Diversity;' and to 'obtain self-government for Fiji by all legitimate and peaceful means.' The party's head office was set up at Lautoka; Working Committees were established throughout the country, and duties and obligations of the office bearers outlined in nine pages of foolscap size paper. Patel was elected the founding president and party leader and Siddiq Koya the first vice-president. ${ }^{12}$

In late 1964, the government announced that a constitutional conference would be held in London to decide the next step in Fiji's move towards self-government. The Colonial Office informed Fiji that 'The British Government accepts that the time is approaching when the future relationship between Fiji and Britain should be clarified and codified, and will be glad, in consultation with representatives of the people of Fiji, to work out a constitutional framework which will preserve a continuing link with Britain and within which further progress can be made in the direction of internal self-government.' ${ }^{13}$ Following instructions from Whitehall, Governor Jakeway initiated a series of consultations with all the principal political leaders, which in turn led to a series of confidential meetings under his chairmanship. The purpose of the meetings, Jakeway explained, was to get members 'into the habit of exchanging views in a civilised, restrained and courteous manner. ${ }^{\prime 4}$ That was the only way compromise could be reached. Members would be encouraged to make suggestions, and agree on issues before proceeding to London for a constitutional conference. Ratu Edward Cakobau and John Falvey thought that the delegates and the leaders should reach a substantial measure of agreement among themselves before going to London. But Patel disagreed, saying that London 'might, after all, be the best place to iron out difficulties, since members would be away from outside pressures,' and the Colonial Office would have experts to guide discussions.

\footnotetext{
themselves as the taukei - the owners of most of the land but economically backward and overtaken in population by immigrant races.'

12 The concept of Working Committees is a direct borrowing from the structure of the Indian National Congress.

13 Secretary of State for Colonies Despatch no 388 (15 August 1963).

14 What follows is based on Patel's private papers.
} 
Not everyone agreed with this view. Kisan Mitra, for one, castigated Patel for accepting the invitation to go to London. How could he justify this decision after criticising Britain all along? It would be far better for a representative of the Colonial Office to come to Fiji, so that all the Indian people of Fiji, and not only the Federation Party, could participate in the discussions. ${ }^{15}$ Apisai Tora was opposed to any Indian participation in the conference altogether, whether in London or Fiji. The Deed of Cession was signed by two parties, the Fijian chiefs and the British Crown, and, therefore, he said, 'it is only right that only the signatories to the Deed should take part in the deliberations. ${ }^{\prime 6}$ Many Fijians agreed, but the Colonial Office stood firm.

Who should attend the London conference and how delegates were to be chosen, became an issue which nearly derailed the discussions then under way. At a conference in December 1964, the Governor had apparently suggested that each ethnic group would select its own delegates to the conference. On 26 January the following year, Patel nominated himself, James Madhavan, Chirag Ali Shah and Siddiq Koya as the Indian delegates. The Fijian members had selected Ratu Mara, Ratu Penaia Ganilau, Semesa Sikivou and Ratu George Cakobau as their representatives. No one objected to the composition of the Fijian delegation, but Ronald Kermode asked Jakeway why the Federation had chosen only its own members, leaving 'a very large section of the Indian community totally unrepresented.' The two non-Federation members agreed. Andrew Deoki suggested that all the 18 unofficial members of the Legislative Council should select delegates. Koya objected, reminding the Governor of his understanding that each group was to select its own delegates. Jakeway rejected Patel's choice of only the Federation members, and said that the Secretary of State for the Colonies would not agree either. As far as he was concerned, the Federation group did not necessarily represent all Indian political opinion in Fiji. ${ }^{17}$

Later that day, Patel wrote a strong letter of protest to the Governor. At no time was the Federation told that candidates would be selected by the Legislative Council, Patel said. If such a suggestion had been made, it would have 'been bitterly opposed' by the Federation Party. 'In the proceedings of the Legislative Council and other matters connected therewith, the democratic method of taking decisions by the majority is followed without exception and we fail to see why you should require an unanimous decision on the part of the Indian members on this matter,' the letter said. The Federation Party would resent 'the interference of any member of another racial group in the selection of the delegates from our group.' The suggestion had 'given us the strong impression that this is being done to introduce discord and disunity on the Indian side at

15 Kisan Mitra, 13 January 1965.

16 Nai Lalakai, 24 June 1965.

17 Jakeway's letter to Patel on 28 January 1965. 
the London Constitutional Conference vis-a-vis the Fijians and Europeans. For the conference to succeed in its undertaking, it is imperative that the delegates of each racial group are able to speak with one voice and have the confidence, trust and the backing of the community they represent.' The Federation Party was the representative party of the Indian community, and there were no sectional interests represented by Deoki and Singh that the Federation group itself did not represent. In the 1963 election, the Federation group argued, one of its platforms had been to 'bring about constitutional changes to give Fiji internal self-government and we claim that a specific mandate was given to us on this subject.' If the constitutional conference was to succeed, it was important for London to 'know what the Indians as a whole want and not the individuals or splinter groups.' Whitehall listened, and the Governor relented: all elected unofficial members of the Legislative Council were to be invited to London.

After the initial hiccups, confidential discussions began to take place among the elected members of the Legislative Council and agreement was reached on a number of issues, all paving the way for greater internal self-government. The Crown would be responsible for external affairs and defence but on other matters, the Governor would be obliged to act on the advice of the premier who, in turn, would govern the colony through a cabinet. Civil servants would not be allowed to contest elections, as they had been in the past; nor would there be any nominated members in the Legislative Council. Patel's point about the Speaker of the Council being elected by the House itself was accepted, over some objection. So, too, was the removal of literacy qualifications for voters. Universal franchise for all ethnic groups had been introduced in 1963.

Semesa Sikivou asked the Indian members for their views on common roll, the central plank in the Federation Party's platform, and an Indian demand since 1929. It was the one issue which deeply polarised the country. Fijians and Europeans were totally opposed to it though, as Ratu Edward said at the meeting, 'a time might come when the introduction of common roll would be possible.' That time, it was clear, was in the very distant future. Semesa Sikivou told the meeting that 'he had a definite mandate from the Fijian people not to support measures for the introduction of a common roll.' Until his constituents told him otherwise, he would not alter his position even if he were to take part in discussions.' For his part, Patel invited all members to a meeting where he explained his position. His letter is reproduced in full:

You will remember that when the idea was first mooted that unofficial members of the Legislative Council should hold meetings in Fiji among and between themselves on the proposed constitutional changes, it was generally agreed that the sole purpose of such meetings would be ascertain and determine the areas of agreement and disagreement on the subjects under discussion. We have had three (3) such meetings under the 
chairmanship of His Excellency the Governor and an additional meeting under the chairmanship of the Honourable Ratu Edward Cakobau. On a close analysis of the matters already discussed at these meetings and those which appear on the Paper circulated to the Honourable Members by His Excellency the Governor, it is abundantly clear that we have now reached the stage that nearly all remaining subjects for discussion are controversial and one on which it is very unlikely any agreement would be reached in Fiji.

Bearing these in mind, I have, nonetheless, decided to give an outline of my views and those my colleagues why we advocate Common Roll and oppose Communal Roll in Fiji. I appreciate that some of you gentlemen would not agree with the views I now express but I assure you that they are being put forward so that you may seriously consider them before going to London.

Our case for African Colonies.

Common Roll as against Communal Roll is as follows:

(a) It is only through making one nation out of Fiji that we can achieve the sort of future we want for everybody. This goal can only be achieved if we accept a Common Roll system of election.

(b) Common Rolls have been successful in a plural society. Examples are the former East and West African Colonies.

(c) Common Rolls will encourage the citizens to organise political parties along national lines and in the long run compel everyone else to think in terms of his country rather than a particular race, community or religion.

(d) Communal Rolls stand for divided loyalties, inhibit national consciousness among the people; and are generally identified with religious fanaticism or racial separatism or economic or social privilege.

(e) Communal Rolls can be a serious obstacle to the successful operation of parliamentary democracy. The elected representatives of a racial or religious sub-community cannot afford to subordinate the interests and prejudices of their people to those of the larger community. Whether elected as independents, members of a communal party, or even as members of a party professing to transcend communal lines, they will not accept party discipline in a way to offend the group upon whose support their political future depends. It will inhibit the formation of secular parties. Success in politics will depend upon reflecting exactly the communal interests and prejudices. Compromise will be rendered 
difficult and relative party strength may be frozen for long periods because a party can grow only with an increase in the size of the community upon which it is based. In such a case government formed by one, or a coalition of two or more of these communal parties, may not be able to meet the challenge of urgent social problems and a breakdown of representative government may occur because the legislators and executives are prevented by communal loyalties from attacking problems in a common-sense fashion.

(f) Communal Rolls tend to magnify communal differences and new communities discover themselves as further claims to separate representation are lodged.

(g) Communal Rolls, to the best of my knowledge, have been abandoned (with a few exceptions) by all the countries of the world.

I do take into account and appreciate the reasons why some of you gentlemen find it difficult to accept a Common Roll at this stage. On the other hand, it is pleasant to note that generally speaking a number of us have accepted a Common Roll in principle but they only wish to postpone its application till some future time.

I sincerely believe that our salvation lies in making one nation out of Fiji and for this and this reason alone, my colleagues and I commend our proposal for a Common Roll to you for your serious and earnest consideration.

Common Roll was an idea that Patel would advocate tirelessly throughout the sixties. But his opponents rejected it with the same passion with which Patel articulated it. John Falvey outlined the objections at one of the meetings, expressing views widely shared by the Fijian leadership as well. The system of communal representation was well established in Fiji; it had worked well; a system of guaranteed racial representation produced no fears of any one group dominating others; it accepted 'realistically the fact there are differences of custom, language, religion, and to some extent of interest, among the various races of Fiji, and it provides a practical way of harmonising these differences through people working together in orderly good-will.' 'Any major change proposed for Fiji should be judged, and decided upon, only in the light of Fiji's special circumstances and special requirements, and only in accordance with the freely determined and expressed wish of the people of Fiji.' 'We should insist,' Falvey said, that 'there should be as little disturbance of the present situation as possible.'

The average Fijian fear about the Common Roll was expressed by the Nai Lalakai. Common Roll would mean: 
there will no longer be representatives of the Fijians, as a race, in the Legislative Council. There would be no European representatives, as they are a minority race. It follows that a majority of the members of the Legislative Council, assuming that common roll is applied to Fiji, will be Indians because they are numerically superior. They have the maximum votes in most of the constituencies in Fiji. Decisions in the Legislative Council will be decided by a show of hands which is a situation where Mr Patel will thereby realise his aims concerning lands and the leasing of lands. Moves can also be made to abolish the laws and ordinances of the Native Lands and Fisheries Commission and also the Fijian Affairs Ordinance on which the Fijian Administration is based. These are some of the things which can be done by Mr Patel and his followers if a common roll is accepted. If this is not so then what really lies behind the proposal to have a common roll? ${ }^{18}$

'E na vula se na balabala,' said many Fijians. We will have common roll when the balabala flowers, which, of course, it never does. Or when the eel grows hair. Patel's answer was simple. It was precisely this kind of mentality, fostered by the system of racial politics, that fuelled suspicions and anxieties among the people. Common Roll did not mean the tyranny of the majority, nor did it imply the derogation of the rights of the minority. The Sovereign would retain the power to amend, suspend or revoke the Constitution, and disallow certain bills. The Governor would retain the right to reserve bills for assent by the Sovereign; he himself could refuse assent to certain bills; and there would be certain 'neutral zones' in the public sector through the creation of independent commissions. If further safeguards were needed, Patel went on, he would like them to be entrenched in the constitution so that Fijian land ownership rights were inviolable and could not be challenged except through the concurrence of the Secretary of State for the Colonies. Indeed, he was ready to endorse 'any other safeguards which would not be incompatible or infringe the principle that each citizen has one vote, one value, in a single member constituency under the future constitution.'

Battle lines were thus drawn. This became apparent in the submissions various groups made to Mrs Eireen White, Under Secretary of State for the Colonies, when she made a fact finding visit to Fiji in May 1965. Basically, the Fijians wanted the principle of Fijian paramountcy reiterated as a precondition for any further constitutional changes. Indian groups demanded some honourable form of power sharing based on universal and equal franchise, and Europeans asked for the retention of their privileged position on account of their dominant position in the colony's economy. In the country at large, there was an atmosphere of apprehension and anxiety. The uncertainty about the outcome of

18 Nai Lalakai, 29 April 1965. 
the negotiations fuelled fears and suspicions on all sides. Making matters worse was the appearance in the daily media of selected portions of the discussions which were supposed to be confidential.

On 26 April, the Federation group decided to terminate its participation in the informal discussions, which caused much controversy. The boycott decision was taken at the Federation Party's annual general meeting at Lautoka on 25 April. The party accused the Fiji Times, the Public Relations Office and the Fiji Broadcasting Commission of being anti-Federation, distorting translations of the party's views on the proposed constitutional changes in Fiji, and generally creating 'animosity, misunderstanding and disharmony' among the people. ${ }^{19}$ For these reasons, it was 'inconceivable that any good purpose would be served by holding further discussions in Fiji between the Honourable Members of the Legislative Council on constitutional matters.' Patel, Shah, Madhavan and Koya were empowered by the meeting to 'make all such representations and submissions which they may think fit and proper in their absolute discretion on all matters to be discussed at the said conference with a view to obtaining fair, just and equitable rights for the Indians in Fiji and with a view to making a nation out of the several communities who live and belong to Fiji.' ${ }^{20}$

The boycott decision was not taken lightly. There was deep anger among the Federation supporters over their real or imagined sense that the media was deliberately fostering anti-Federation feeling in the country. The way the Fiji Times had covered the 1960 strike as well as other events, suggests that, at least against this newspaper, that feeling was not unjustified. Patel detected a clear strategy to derail his common roll platform. He suspected an orchestrated effort by his opponents to undermine his campaign for political independence. At a meeting at the Lilac Theatre in April 1965, he said: 'A common method of forcing a tiger out into the open from its hiding place is to create as much noise by beating and banging whatever comes handy. When the din brings the animal out, he becomes an easy target. I hope that the Indians here will not find themselves in the same situation someday. ${ }^{21}$ There was no dispute between the Fijians and Indians, Patel said; there was no reason for it. 'But we certainly have a right to decide for ourselves as to what is best for us. By deciding not to enter into further discussion here on political changes, we are not doing anything against the interest or security of anyone else. We have been compelled to take this step because much of what we say is distorted to a dangerous level.'

What the country did not know was the extent to which Patel had gone to try and find a common ground with the Fijian leaders. ${ }^{22}$ When the discussions

19 See also Alley, 1973, 179.

20 In Patel's private papers.

21 Pacific Review, 12 May 1965.

22 Based on a tape of an interview with A.D. Patel (by Robert Norton). 
began, Patel wanted to have direct talks with Ratu Mara, the principal Fijian leader. If only the two could talk together, face to face and honestly explore each others' fears and concerns sincerely, most of the problems would be resolved, Patel believed. According to Patel, Mara was lukewarm to the idea, and sent John Falvey to talk to him instead. Patel was disappointed. He believed that these intermediaries, who had vested interests of their own, were themselves a part of the problem. He listened to Falvey but did not respond. Later, he asked Ratu Edward, whom he trusted and liked, to arrange a meeting with Ratu Penaia Ganilau and Ratu Mara. Ratu Edward Cakobau organised an informal dinner at his place in Domain for the four of them, but Ganilau and Mara did not turn up, which embarrassed Cakobau and confirmed to Patel that the two were not prepared to have serious face-to-face discussions, without the presence of their European colleagues. Hence, Patel concluded, it was fruitless to conduct further discussions in Fiji.

Nonetheless, Patel's decision was widely criticised. M.V. Pillay called Patel a petulant man reminding him that at the London conference he was representing not only the Federation Party but the entire Indian community, and not all Indians were members of that party. "The future of every man, woman and child is in the balance,' Pillay argued. 'We want the fullest disclosure. We want to be able to study and learn the views of the leaders and offer suggestions when necessary. ${ }^{23}$ That was fine, but the Federation Party's views were already well known. Others rejected the common roll in favour of the communal roll as the best option considering the realities of Fiji politics and asked Patel not to push the point too far. Ajodhya Prasad's National Congress of Fiji passed a resolution at $\mathrm{Ba}$ in mid-June rejecting common roll. K.S. Reddy agreed. Fiji had the communal roll since 1929: why not carry on, why risk suspicion and mistrust, he asked. Kisan Mitra added: 'How could all the people of the various races get together and conduct elections peacefully when the Federation does not desire to discuss the matters with the other races.' Patel, it said, 'is always trying to obtain rights by displeasing others, which is impossible in a multiracial country such as Fiji. ${ }^{24}$ Patel would not budge on the common roll issue.

But it has to be said that given the Fijians' and Europeans' almost visceral opposition to the idea, little more could have been achieved by further discussions in Fiji. Even the government itself seemed unsympathetic and unwilling to listen to alternative views. Sir Derek Jakeway had showed his hand when he made a remark that was widely condemned in the Indian community. In March 1965, he had said: 'I thought it was common ground that the Fijian people - the autochthonous people - have a special position in Fiji because they belonged here first, long before anyone else came here. It was inconceivable

23 Fiji Times, 3 May 1965.

24 Kisan Mitra, 4 August 1965. 
that Britain would ever permit the Fijian people to be placed politically under the heels of an immigrant community. ${ }^{25}$ With the Governor taking sides, there was little hope for open and genuine exchange of views which might produce compromise. Patel hoped to persuade the Colonial Office to put pressure on the Fijian and European delegates to at least think seriously about the idea.

The deliberations of the United Nations General Assembly Committee on Decolonisation in the early 1960s coincided with the constitutional discussions and aroused great controversy in Fiji. As far as the government and Fijian and European leaders were concerned, the UN had no business discussing Fiji's political situation, and they derided its deliberations in stinging terms. The people of Fiji knew little about the UN and its views on decolonisation. Patel's Pacific Review had published the mandate of the Committee on Decolonisation in full. The Committee had rejected the delaying of independence to colonial or dependent territories on account of their social, economic and political preparedness, urging the colonial powers to expedite the process of selfgovernment which would, in due course, lead to full independence. In November 1964, Afro-Asian members on the Committee drafted a resolution, asking Britain to reaffirm 'the inalienable right of the people of Fiji to selfdetermination and national sovereignty,' and to take 'immediate steps to hand over power unconditionally to the people of Fiji.. ${ }^{26}$ Questions were asked about European over-representation in Fiji's public life and the inordinate amount of power exercised by the executive authority.

Not surprisingly, the local establishment was furious that Fiji's internal problems should be discussed in such an open way. Ratu Penaia Ganilau criticised the Committee for ignoring the 'repeated expressed desires of the native Fijians to retain British protection..' 'We know Fiji, they don't. We know of the kind of future we want. They don't. We treasure our trust that was expressed in the signing of the Deed of Cession. They have never heard of the Deed of Cession.' The Fiji Times editorialised Macbeth's celebrated observation on life as 'a tale told by an idiot...full of sound and fury signifying nothing,' which might be aptly if unkindly, applied to much of the twaddle talked in the United Nations Committee on Colonialism about Fiji. ${ }^{27}$

Many suspected Patel of instigating the Committee's unusual interest in the affairs of Fiji and its condemnation of the slow pace of its political progress. I have not been able to discover Patel's direct link or involvement with the Committee, but would not be at all surprised if there were one. The UN's declarations confirmed to his supporters that Patel was not the dangerous and irresponsible radical his

25 Fiji Times, 2 March 1965.

26 Pacific Review, 16 December 1965.

27 Fiji Times, 6-14 November 1964. 
opponents made him out to be. His ideas and philosophy found resonance in the international arena as well. Fijians and Europeans might ridicule the United Nations, but Patel knew that Britain could not. When it was suggested that the UN Committee on Decolonisation send a fact-finding delegation to Fiji, Patel welcomed the idea. He told H.M. Lodhia that a Fijian village would be first place he would take the mission to show how little progress Britain had made in improving sanitation in the rural areas, how backward the conditions of life in the koro really were. ${ }^{28}$ But whatever his plans, the UN's deliberations hardened Fijian and European attitudes towards the Indian leaders, especially Patel.

For some Fijians, all this was yet another sign of Patel's intransigence. Among them was Apisai Tora. The co-leader of the 1959 strike and self-styled Fidel Castro of the Pacific, Tora was the founder of the Fijian Democratic Party. In May 1965, addressing a party meeting at the Kisan Hall at Lautoka, he called for a commission to investigate the possibility of re-settling the Fiji Indians in some other parts of the world. 'If Fiji's and Fijian interests are to be protected then the quickest possible way should be found to send the Indians to other countries.' Burma and Ceylon were doing it, he said, and Fiji should learn from their example. The Europeans were alright, Tora said; it was the Indians who were the problem. 'We know the Europeans and we can get along with them. We also know what they will advocate in the coming London conference. As for the Indians, we do not know what they want or what they are going to say in London. They are keeping quiet, and we don't like it. ${ }^{29}$ Indeed, as already mentioned, Tora was among those who wanted Indians totally excluded from the conference. A Volagauna correspondent agreed, but for another reason: 'The Fijians and Europeans are benevolent and patient and are not greedy [like the Indians]. They can evenly distribute things so that peace and harmony can prevail in Fiji. Both belong to the Christian faith. They act like Christians and they will never wish to deprive anybody else of what is rightfully theirs. ${ }^{30}$ For its part, the Colonial Office rejected the demand; this was a conference to decide the future of all the people of Fiji, not the future of the Fijian people alone.

The Fiji delegation left for London agreed that the question of land ownership would not be touched at the conference and that immediate independence was not the goal for Fiji, but divided and unclear about the most contentious issue of all, the method and nature of election to the Legislative Council. The conference was held at the Marlborough House from 26 July to 9 August. Anthony Greenwood, Secretary of State for the Colonies, chaired the first session, and the remaining fifteen were chaired by Eireen White. All the three principal leaders made opening statements. John Falvey said that 'there are many people

28 Personal communication.

29 Fiji Times, 17 May 1965.

30 Volagauna,22 January 1965. 
in Fiji who are well content with our present and quite new constitution,' and there were 'few who are seriously critical of the administration of our country since 1874. ${ }^{31}$ Not one member of the European delegation was there to ask for immediate independence for Fiji. 'We might rather be said to be in the forefront of the smaller British territories which, not unnaturally, aspire towards a system of internal self-government, but which insist upon a continuing link with the Crown.' That form of constitutional association was, said Falvey, both sensible and realistic. Ratu Mara said: 'We have declared that independence is not our goal because we have never found any sound or valid reason to attenuate, let alone abandon, our historical and happy association with the United Kingdom.' He spoke warmly of 'mutual trust and abiding loyalty' between the Fijian people and the people of the United Kingdom, and of 'enduring faith and loyalty in the British Crown and in British institutions.' Instead, he expressed the hope that the UK 'will share with us our prosperous future as she has always willingly and unstintingly shared our past and our present.' So, for Falvey, and Mara, a minor alteration in the direction of modest self-government perhaps, but no fundamental redirection of policy or re-structuring of the relationship between Britain and Fiji.

Patel couldn't disagree more. As agreed in Fiji, he did not ask for immediate independence, but expressed the hope that the conference might set in motion a train of events which would lead eventually to full independence. Here is his speech in full:

I thank you and the United Kingdom Government for the kind invitation and welcome extended us to this historic conference which is called to smelt the existing system of government in the Colony of Fiji and to forge and mould a new constitution in the not too distant future.

Political liberty, equality and fraternity rank foremost among the good things of life and mankind all over the world cherishes and holds these ideals close to its heart. The people of Fiji are no exception.

Without political freedom no country can be economically, socially or spiritually free. We in Fiji, and in many underdeveloped countries of the world, are faced with the three most formidable enemies of mankind, namely, poverty, ignorance, and disease. We need political freedom to confront these enemies and free our minds, bodies and souls from their clutches.

Needless to say that when I refer to political freedom, I mean democracy under the rule of law, the sort of freedom which the British people and the people of the United States enjoy. We need freedom which will

31 Brief reports are in Fiji Times, 27 July 1965. 
politically, economically and socially integrate the various communities living in Fiji and make out of them one nation deeply conscious of the responsibilities and tasks which lie ahead.

I call this Conference important and historic because it is the first Conference of its kind in the history of Fiji and it may very well prove the beginning of the end of a form of government which stands universally condemned in the modern world.

I have come to this Conference with faith and trust in British people and their government which has set people of other colonies free and has led them on the path of economic and cultural development. After all Fiji's problems are not as difficult or formidable as those which some of the Colonies which are now independent have had to face and solve.

We from our side promise you full co-operation and serious consideration in the deliberations which lie ahead in this Conference.

We have all got to guard ourselves against avoiding right decisions because they are unpleasant or run counter to our ingrained habits of pre-conditioned thought, or taking wrong decisions because they appear advantageous in the short run.

We must appreciate the fact that we owe great responsibility, not only to the people of the present generation but also of generations to come. We have to resist the temptation of driving the boat on the shallow waters because of the fear that it will rock heavily if we steered it on the right course. Bearing all this in mind, let us bend to the tasks before us.

In the end I pray to the Almighty God who led the Crown colonies like Australia and New Zealand to full independence, may He also lead us and our country to the same destination safely and in good heart.

The record of the conference proceedings remains confidential, but Patel's private negotiating notes indicate the direction of his thinking. It is clear that Patel wanted not only the spirit but also the substance of full internal self-government entrenched in the constitution. 'The constitution should empower the local government to conclude trade agreements with other countries and provide for further delegations of authority to be made by the British government.' As far as possible, Fiji should have a 'full international personality' and 'Statute of Westminster legal status.' Britain should give explicit assurance that the 'field of self-government [would] be inviolable' and that therefore 'it would be improper to encroach upon it.' The real power should reside with the elected representatives of the people, the Governor, as the Queen's representative, acting on important matters on the prime minister's advice. The Governor should not 
summon, preside at, or attend cabinet meetings, which should come under the control of the prime minister. The independence of the judiciary must be secure and free from political interference, and special independent commissions should be set up to advise the government on matters relating to the public service, the police and the judiciary. In other words, the power of the executive should be severely restricted and, wherever possible, made subordinate to the power of the elected legislature.

On the election to, and composition of, that legislature, which was perhaps the most contentious issue at the conference, Patel argued that there should be a single chamber parliament, with no ex-officio or nominated official or unofficial members. There should be no communal and non-communal members elected on separate, mathematically weighted rolls, nor should there be specially elected and nationally elected members. There should be no multi-member constituencies. Was there a case for proportional representation? The best system was common roll, one man, one vote, one value, elected on the basis of universal franchise from single member constituencies using the first past the post system. The Legislative assembly should be a wholly elected one, with the Speaker coming from among its members. And the delimitation of electoral constituencies should be left to an independent electoral commission.

Patel had done his homework. The thoroughness of his preparation, his attention to and mastery of the detail, somewhat in the manner of a barrister preparing a case for appeal, is impressive. Nothing of importance escaped Patel's notice. As it happened, many of his points were incorporated in the final report. ${ }^{32}$ For instance, the new constitution provided for a Public Service Commission, a Judicial and Legal Services Commission and a Police Services Commission, each advising the Governor on matters under their separate jurisdictions. There were safeguards against the abolition of the office of any judge during his tenure. The new constitution had a Bill of Rights to guarantee freedom from discrimination without derogating from discriminatory sections of existing legislation, a point the Indian delegation fought hard but unsuccessfully to eliminate from the constitution. The people of Fiji had universal franchise without any property qualification. A full ministerial system of government was to be introduced. The nomination of unofficial members in the Legislative Council was discontinued, but the government, with the support of Fijian and European delegates, retained four nominated official members in the Legislative Council (that is, the Colonial Secretary, the Financial Secretary, the Attorney General and the Secretary for Fijian Affairs).

The Legislative Council itself was expanded to 36 members: 14 Fijians (nine elected from the communal roll, three from cross-voting roll, and two nominated 
by the Great Council of Chiefs); 12 Indians (nine communal and three crossvoting); and ten Europeans (seven communal and three cross-voting). The introduction of cross-voting, where multiracial electorates voted for candidates of different ethnic groups, was seen as a compromise by the United Kingdom and an important concession by the Fijian and European delegates. That was the furthest they were prepared to go, encouraged by messages from Fiji to walk out of the conference if the 'Colonial Office wallahs' (Apisai Tora's phrase) insisted on the introduction of a common roll. Some Fijian leaders threatened to boycott the conference if the UK delegation demanded any further concession. The Europeans made much of their gift of two seats to Fijians, though, in truth, they had very little choice in the matter. The UK government was ready to whittle the European numbers down even further but baulked when the Fijians advised against it. The Europeans also claimed credit, for which they wanted praise not criticism, for opening up their electorate to Chinese and Rotumans who were enfranchised for the first time. Pacific islanders were put on the Fijian roll.

On many important issues the Indian delegation lost out. The principle of parity which Indians had enjoyed with the Fijians since the 1930s was now gone. Politically, the Indians were even further isolated. While Fijians had other Pacific Islanders on their rolls and Europeans had Chinese and Rotumans on theirs, the Indians were by themselves. As Patel said in a speech at Albert Park, a speech which provoked considerable comment, why were Chinese who ate 'rats, bats and cats' placed on the same roll as Europeans when culturally and historically the Indians and Europeans had more in common with each other? Putting it another way, while the Europeans and Fijians had common roll among themselves, it was the Indian community which was now confined to the communal ghetto. Patel pressed hard for a common roll. When it became clear that the Fijians and Europeans would not budge beyond conceding a few crossvoting seats, Andrew Deoki made a compromise proposal that attempted to bring together the communal, common and cross-voting rolls into one system. Deoki proposed that 12 seats, four each from the three ethnic groups, be elected on communal roll; 18 from cross-voting seats (six Fijians, six Indians, three Europeans and three (one each) from Chinese, Rotumans, and Pacific Islanders. The remaining six seats, Deoki proposed, should be elected from a common roll. Deoki explained: 'We made it very clear that compromise proposal was being put forward for the purpose of discussion by all members of the Conference. We also made it clear that we were not going to stick rigidly to the details of the compromise proposal; that was a matter for discussion amongst the 18 of us. So long as, in principle, there was an acceptance of the common roll idea in part, and the cross-voting, with reservation of seats idea in part, and the system of communal election in part, the details could be discussed and 
agreed upon by the 18 members of the Conference.'33 Deoki thought the UK delegation was impressed with the proposal, but when Europeans and Fijians refused to consider it, the proposal was dropped because, the Colonial Office said, it had come too late in the discussions, at the end when the conference was about to close. The Federation group then returned to their original common roll platform.

When the conference ended, Patel and his group rejected the report and recommendations of the conference. Indeed, they had nearly boycotted the last session of the conference but had held back, in Koya's words, 'out of respect for the Crown and in the belief that the British Government will not impose on any community in Fiji a constitution which is unfair, unjust and undemocratic.' The Indian group was 'bitterly disappointed' with the results. 'Since the conclusion of the Conference we have given serious and anxious consideration to the proposals and after a long deliberation we have come to the view that we must reject them.' In a public statement, Patel wrote: 'The Indian group unanimously rejects the proposal that there should be two more Fijian members of the Legislature than the Indian members. They reject the argument of the Fijian and European groups that this additional representation is justified by a 'special' position occupied by the Fijian community in Fiji. They also reject the argument of the UK delegation that two extra Fijian seats are justified by the inclusion of the Rotuman and other Pacific Island communities in the Fijian electorate. The Indian view is that they represent the majority of the community in Fiji and that they are therefore entitled to at least as many seats as the Fijian, Rotuman and other Pacific Islanders command.'

Britain was not entirely free from blame for the way it had conducted the conference. The UK delegation had 'made no serious effort to impress upon the Fijian and European delegations of the efficacy, practicability and the need to reach a compromise. Such a compromise was, in our view, highly probable if only the United Kingdom delegation had not committed themselves at the onset to its proposals for cross-communal system of voting and had cared to spend more time in the negotiation with various groups separately and collectively at the Conference.' Britain's attitude had led to the Fijian and European delegates to believe 'that the rejection by them of constitutional proposals to the unreasonable detriment of the Indian community would be adopted by Great Britain without due regard to the requirements of fair play and justice to all communities.'

On 12 August, a week after the conference ended, Patel wrote to Anthony Greenwood, explaining his objections to the final report, the effects of entrenching the communal system, and his intention to oppose the recommendations by 
all constitutional means. The full letter is at the end of this chapter. Patel reminded Greenwood of the British Government's promise over the years that the Indian community in Fiji would enjoy the same rights and privileges as other communities in the Colony; he referred to the Salisbury Despatch and argued that 'the proposal to give two extra seats to the Fijians constitutes, in our view, a clear breach of Lord Salisbury's Despatch on the part of Her Majesty's Government.' He said that 'the United Kingdom Delegation's proposals relating to the composition of the Legislature and the method of election are so unjust, unfair, impracticable and undemocratic that they will harden the existing racial divisions and make political integration extremely difficult, if not impossible.' He accused Whitehall of not making a serious effort to consider the compromise proposals put forward by his side. It had been agreed that land would not be discussed in London, and yet it was. 'We cannot for one moment accept the proposition that the existing Native Land Trust Board Ordinance ought not to be changed. On the question of Native land, we cannot help saying that neither the Government of Fiji nor the architects of the relevant Bill in 1940 have honoured their undertakings which were given to the Legislative Council.' The Ordinance contained 'unjust and iniquitous provisions and its operation has not helped the country, let alone the Fijian owners and Indian tenants.' Patel told Greenwood that he was deeply disappointed with the proposals for constitutional reform. Their implementation 'would create a grave racial disharmony leading to undesirable results. In this process an irreparable harm would be done to the country as a whole and we fear that goodwill, harmony and understanding, which has existed among all the races in Fiji over the last 90 years, would disappear forever. The responsibility for any course of events arising out of the implementation of these proposals would rest, in our view, on Her Majesty's Government.'

Greenwood sympathised with Patel, but in his reply of 9 September, said that it was not 'possible for the British Government in all the circumstances to impose an a priori solution of this type [full internal self-government based on the common roll]. The British Government took considerable pains before and during the conference to ascertain the views of all groups and communities in Fiji and the proposals put forward by the British Government and eventually accepted by a majority of the delegates at the conference constituted an attempt to make progress towards the general objective in a way which took into account the interests of all concerned.' Patel could, of course, oppose the report, though Greenwood asked him to remember the consequences of outright opposition. 'In my view, it is far more likely to increase the suspicions of the other communities, particularly the Fijians, than to win them over to support your point of view, which must surely be your objective. I believe that a much more fruitful course of action and one which would be far more likely to lead to the political integration and racial harmony which we all want to see achieved, 
would be to co-operate fully in the introduction of the new constitution and, by showing that the measure of inter-racial voting which it will introduce does not adversely affect the interests of any race, to pave the way to further constitutional progress. ${ }^{34}$ Patel accepted the constitution but only under protest.

Fijian and European delegates were delighted with the conference's outcome. A tiny minority in the population, the Europeans had managed to retain their privileged position, with the added bonus of renewed Fijian support. The principle of Fijian paramountcy had been explicitly recognised in the constitution with the allocation of two extra seats, which was as it should be, according to Ratu Edward Cakobau, because Fijian interest was 'fundamental and it must be given priority.' Ratu Mara cabled Fiji: Na yalovinaka ni kakua ni taqaya, na veika kece koni taqayataka e seqa ni yaco, sa nomuni na lagilagi' [Don't be concerned. All that you were concerned about, did not materialise. The victory is yours]. ${ }^{35}$ The Fijian delegates returned to grand traditional ceremonies of welcome, jointly organised, at the suggestion of Adi Litia Lalabalavu and Ratu Naulivou, by the three confederacies of Kubuna, Tovata, and Burebasaga. It was the first time in modern Fijian history that the three groups had come together to perform such a ceremony. The symbolic message of Fijian unity could not have been more forcefully expressed. Mara expressed his gratitude to the Europeans for their magnanimity. 'I am very pleased indeed particularly at the way the Europeans have behaved,' he said. 'We have gained two more seats in the outcome at the expense of the Europeans. This proves to me that greater love hath no man than he lay down his life for fellow men, and this is what the Europeans have done for the Fijians at this conference.' Turning to the Indian leaders, he said: 'This constant pin-pricking, the constant endeavour to drive a wedge between Fijians and Europeans is not only stupid but fruitless. Speaking as a representative of the Fijian people, I can say that [the Federation Party] will never achieve its end.'

Patel stayed back in London for a few weeks, spending time with his children, and sightseeing. On his way back, he spent a few more weeks visiting relatives in India. Patel's absence aroused suspicion, enough for the Volagauna to write an editorial headed 'Is He Back?' 'Patel's long stay in India has given rise to speculation by a majority of the people of Fiji, particularly Fijians. Does anybody know what his intentions are?' Was Patel seeking the Government of India's assistance for his party? That was hardly the case, with India engaged in a tense stand off with China and Pakistan, but the editorial says something about how many Fijians saw Patel. He was just too clever, too crafty to be trusted; Patel was always seen to have a card hidden up his sleeve. They feared his political cunning.

34 Greenwood's letter in Patel's private papers.

35 See Lal, Broken Waves, 199-200. 
Patel's defiant stand had won him the admiration of his followers, but it also deepened bitterness against him in his opponents. Andrew Deoki, the architect of the compromise proposal, distanced himself from the Federation platform and Singh laid all the blame for the Conference's failure at Patel's door. Ajodhya Prasad revived his anti-Patel and anti-Gujarati rhetoric. C.P Singh called Patel a petty, selfish man, a wrecker of Indian unity, a man whose conduct at the conference had disgraced the Indian community. Throughout his life, Patel had not been able to 'achieve anything but disunity.' Patel told his audiences that the Indian people should be proud, rather than feel disgraced, at standing up for their rights. There was no disgrace in fighting against racialism and racial isolationism and discriminatory legislation. All should be equal before the law. There was no point in giving up hope and losing heart, there was no point in bowing to what appeared to be inevitable. Truth would triumph in the end, he would say, paraphrasing the philosophy of the Bhagvada Gita. Nonetheless, the Indian community was dispirited and divided, anxious about the future.

In December 1965, Fred Archibald moved a motion in the Legislative Council to accept the conference report as a 'satisfactory basis for future political progress in Fiji along constitutional lines.' ${ }^{36}$ The motion provoked a long, wide ranging and often bitter debate in the Council. Patel opposed the motion, and in the process, explained his objections to the communal and cross-voting rolls which, he said, perpetuated 'division of people on racial lines and prevented them from integration into one nation.' Patel repeated points noted earlier in this chapter. Then, he went into specific issues. The constitution was fair only to two communities, Patel said, the Europeans and the Fijian chiefs. The Council of Chiefs, a small body of men, got two separate seats in the Legislature, while the Fijian commoners and Indians, the two largest communities in Fiji, had only nine seats each. Europeans, even with a few thousand Chinese thrown onto their rolls, were the 'smallest political unit in Fiji,' yet they had seven seats. Numerically, Europeans had one seat for 1,200-1,500 people, Fijians had one for $8,000-9,000$ people and the Indians one for 10,000-12,000 people. 'This roughly means that the European vote is equivalent, as far as representation in this House is concerned, to roughly about eight or nine Fijian votes to ten Indian votes. What could be more unfair than that? How can anybody call that equality of status for all the racial groups in Fiji?' The European group held the balance of power in the House; even the fourteen Fijian members of the House could not form a government on their own without the support of the Europeans.

But not everyone wanted equality, said Josua Rabukawaqa, and nor was that possible or desirable. He quoted Disraeli in support: 'There are two kinds of equality. There is the equality that elevates and creates, and the equality that levels and destroys. You give leadership to the one who has proved himself to

36 The following is based on the debate in the Legislative Council, December 1965. 
the world to lead. He will elevate and create [sic] the others to enjoy the same status that he has.' Britain provided the first kind of equality, Rabukawaqa said; Britain was unique in that it had 'created and elevated all her colonies to enjoy the same status she enjoys.' So any criticism of the 'mother country' was unfair and unwarranted. Ratu Mara made the same point. Fijians admired English culture. 'It is only through aspirations to adopt the best of western culture that the Fijians will abandon some of their own culture.' It was the only culture to which 'we will submit, as Fijians, and to no other culture.' Remove the buffer of European presence and culture, and there would be 'a conflagration in this country because we will have to come to a decision [sic] which culture dominates in this country - will it be a Fijian culture or an Indian culture.' Mara's argument echoed a recurring theme in Fijian thinking: respect for things British, a strong, conservative predilection for law and order, and a sanguine view of colonialism. For them, colonialism was not the malignant disease that was wrecking the Fijian body politic, as Patel argued; British colonialism, Fijian leaders said over and over again, had given them unity, progress and a moral and political order they had not enjoyed before.

Asking for common roll in the context of Fiji society was like putting the cart before the horse, said many Fijian leaders. Rabukawaqa: 'To achieve common roll we must, first of all, achieve common grounds, and by common grounds, I mean common language, common beliefs, common religion, common culture. In Fiji we have different religions, different cultures, different languages which must be moulded first before we can achieve common roll.' Patel disagreed. Political integration should precede and not follow racial and religious integration. He argued that 'neither integration in schools nor racial miscegenation is necessary for political integration.' The United Kingdom, with its myriad of so-called races - Scots, Welsh, English, Irish - had a system of political representation based on common franchise. England had Jews, Roman Catholics, Protestants, Hindus and Muslims, but one common franchise. Closer to home, how come Rotumans, Banabans, Solomon Islanders and other Pacific Islanders, with separate racial and cultural identities, were on the Fijian roll? How come the Chinese were on the European roll? 'As far as they are all concerned, common franchise and common roll is accepted.' Rabukawaqa's argument was hollow, said Patel, and cited the examples of Australia and New Zealand and the United States to show that racial and cultural integration was not a necessary precondition for political integration. 'If these can politically integrate with immigrants who come to their countries and if they can integrate as soon as they set foot into that country and they can be accepted as Australians and New Zealanders, even when they do not know a word of English, I do not see any difficulties when three races who have lived together in this country for nearly 90 years being brought together politically.' 
Common roll would lead to Indian domination - that was the greatest fear that Europeans and Fijians had. There were more Indians of voting age than other groups, and it was an instinctive tendency, whether you were European, Fijian or Indian, to vote for your own kind, said Ronald Kermode. Patel didn't agree. The notion that common roll would lead to Indian domination started on the wrong premise that 'if there is common franchise all will necessarily vote on racial lines.' If that were the case, Patel went on, 'there would not be any meaning in forming alliances under the cross-voting system because you would expect every voter to vote with his racial interest in mind and not with common interest.' There was no such thing as a permanent minority, Patel said. 'Under a democratic form of government, the minority today may be the majority and the government after the next election. The Bill of Rights protected the rights of minorities, the individual being the smallest minority. If individual rights are adequately safeguarded, minority rights are automatically safeguarded because minorities are composed of individuals. Nobody can claim to be entitled to special privilege in a democracy by reason of race, colour, creed, birth or sex.' At the London conference, Patel reminded his critics, he and his group had argued that 'there should be no saving for existing laws which were in conflict with the right to freedom from discrimination and which could not be brought within one of the specific exceptions set out by the Constitution,' but he had been prepared to let them exist for a specified period of time.

Even his sternest critics respected - and said so publicly-Patel's passionate commitment to the principle of common roll. Indeed, they all agreed, including Ratu Mara, that the common roll was a noble ideal; they disagreed with the timing of its introduction. As Mara said, it was an ideal, like going to Heaven was the ideal for Christians. The important question for him was when and how common roll was introduced. Mara was perplexed by Patel's impatience for common roll. His fear of the consequences of communal roll leading to disharmony was unreal, or perhaps simply the projection of his experience of disunity in the Indian community. 'He has put this fear of disunity on a pedestal and lives in dread, practically the whole of his political life, of this disunity.'

When Mara reminded Patel of the communal conflicts in India and Pakistan, Patel responded that the experience of the sub-continent was in itself a very good reason to avoid the system of communal representation. The communal system had exacerbated tensions between the Hindus and Muslims. 'That is why of all the people, Indians are bitterly against communal representation because they have seen its painful results in the course of time. It may not be very serious now, but as time goes on, once people get used to the idea of a racial separation, racial attitudes harden and people start thinking on racial terms and racial interests which lead not to one nation but, in the course of political development, it leads to claims of several nations.' It will divide the 
country, Patel predicted, and bring destruction in its wake. Just how far-sighted Patel was in his prognosis was to become evident two decades after his death Meanwhile, those who had argued that common roll was an ideal striving for, but not immediately, turned their back on the idea once they came to power.

By 1965, with the Federation Party already well established, it became clear that other groups would sooner or later have to form political parties of their own. Ironically, the lead in this direction came from Sir Derek Jakeway. In his address to the Legislative Council in November, he said that the London constitutional conference, and especially the provisions for cross-voting in the new constitution, had laid the foundations for a greater degree of internal selfgovernment. So 'the way is now wide open for leaders of imagination, who have the interests of all the people of Fiji truly at heart, to build political alliances with the object of contesting elections on a common racial platform and then, if they win a majority of seats, forming a broad base administration which will be effectively self-governing. I shall only be too happy to co-operate with such an administration and give it maximum freedom of action.' And then, with Patel in mind no doubt, he said that the claim that the Indian people had been reduced to second-class citizens was entirely without foundation. Patel's plan, as stated in his letter to Greenwood to oppose the constitution through all constitutional and peaceful means, was, in Jakeway's view, a 'retrograde step.' For him, there was no room for an 'attitude of mind which is intent on wrecking it and has no alternative to put in its place.' Jakeway's attitude was not surprising, but it does show what Patel was up against.

Jakeway's exhortation encouraged the leaders of the different groups to accelerate efforts already underway to form political parties. By 1965, a number of quasipolitical parties were already in existence, including the National Congress of Fiji, formed by non-Federation Indians, the Rotuman Association, the Chinese Association, the General Electors Association, the Fiji Minority Party, the Tongan Association and, of course, the largest and most important of them all, the Fijian Association. They all shared broadly the same political agenda of gradual, minimalist constitutional reform, with communal representation at the heart of their platform. They all came together in the Alliance Party under the leadership of Ratu Kamisese Mara on 14 March 1966. In the elections for the 1966 elections, then, for the first time in Fiji's political history, two political parties were contesting for supremacy in the colonial legislature. We shall see the result of that contest in the next chapter.

Here, let us return to the issues raised at and by the London constitutional conference. As already seen, Patel was dissatisfied not only with the rejection, in effect, of his common roll proposal, but also by the United Kingdom's reluctance to persuade the Fijian and European delegations to move further along the path of full internal self-government. His opponents castigated Patel 
as an irresponsible leader bent on wrecking the fragile racial harmony of the country. But independent observers were in fact closer to Patel's thinking than to his opponents'. Among them was Professor Jim Davidson of the Australian National University and a scholar of wide experience in Pacific constitutional matters. Davidson had been involved in Samoan decolonisation process as an advisor. For Davidson, the British Colonial Office had shown:

...only an intermittent and unimaginative concern with the process by which this change [internal self-government] should be brought about.

In the colony itself, senior officers of government have largely retained an attitude of benign, but out-dated paternalism. To these men, there has seemed little need for change. When London has required them to discuss constitutional development with representatives of the local people, they have done so without any deep sense of commitment to self-government and, partly as a consequence, without much political sensitivity or skill. The leaders of the Fijian and European communities have been wary of change lest, in particular, it should enhance the political influence of the Indians. The old technique of 'divide and rule' has thus been maintained, not primarily for the reasons that anticolonialists are wont to assume, but because it has been supported by those groups in the colony that are in closest touch with the official establishment. ${ }^{37}$

The official propaganda surrounding the achievements of the conference was just that, Davidson argued. Insofar as the conference had been a success, 'it had thus been so in terms of short-term political management, not in relation to the resolution of fundamental political problems. There is reason for believing that the Fijians could have been persuaded to abandon their demand for greater representation in the legislature than that of the Indians and to accept a simple common-roll procedure for the election of the nine members to be returned by voters of all communities. The initiative in proposing such concessions would have to come, however, from the British government.' That, of course, did not eventuate. Down but undefeated, Patel continued his by now almost lonely struggle for what he regarded as a more just and fair political system for the remaining three years of his life.

A.D. Patel's Letter to Anthony Greenwood, Secretary of State for the Colonies:

We must point out that the basis of the Indian Delegation's complaint is that their community were at all times led to believe that by becoming settlers and adopting Fiji as their permanent home, they would enjoy rights and privileges no whit inferior to those of other races residing in Fiji. In this connection, we beg to remind Her Majesty's Government that such a guarantee and undertaking was given in Lord Salisbury's

37 'Constitutional Change in Fiji,' Journal of Pacific History (1966), 1:165-182. 
Despatch in March 1875. The undertaking given in this Despatch has never been withdrawn or contradicted. Indeed it was accepted and confirmed by the Crewe Commission in 1910. This Despatch was a subject matter of public discussion in 1963 on the eve of the arrival in Fiji of Mr Nigel Fisher, the then Parliamentary Under-Secretary of State for the Colonies. At the conclusion of Mr Fisher's tour and on the eve of his departure, he made a public statement in which he categorically said that Her Majesty's Government considered that this Despatch was binding on her. He further said that the Indians rightly regarded that the Despatch conferred on them rights and privileges as the Fijians regarded the Deed of Cession in respect of their rights and privileges. In $\mathrm{Mr}$ Fisher's view, the Indians could not be regarded as second-class citizens and that he considered that their rights and privileges were equal to those of other communities in Fiji. May we say without hesitation that the proposal to give two extra seats to the Fijians constitutes, in our view, a clear breach of Lord Salisbury's Despatch on the part of Her Majesty's Government.

We sincerely believe that political integration of the different communities living in Fiji is vital and necessary to the building of a politically homogeneous democratic nation. We assume that Her Majesty's Government accepts this view. However, the United Kingdom Delegation's proposals relating to the composition of the Legislature and the method of election are so unjust, unfair, impracticable and undemocratic that they will harden the existing racial decisions and make political integration extremely difficult, if not impossible.

You will note that at the outset the Indian Delegation asked for the immediate introduction of full internal self-government based on the Common Roll of system of election at the Conference. Nonetheless, our Delegation for the sake of peace and harmony and to avoid a deadlock submitted an alternative proposal. The substance of this proposal was that there should be part-communal, part cross-communal and part common roll method of election. This proposal would have accommodated the views of the United Kingdom Delegation and that of the Fijian Delegation as a whole and thereby satisfying the demands of all races. Unfortunately the United Kingdom Delegation made no serious effort to impress the Fijian and European Delegations of the efficacy, practicability and the need to reach a compromise. Such a compromise was, in our view, highly probable if only the United Kingdom Delegation had not committed themselves at the outset on its proposal for cross-communal system of voting and had cared to spend more time in the negotiation with various groups separately and collectively 
at the conference. We are more than alarmed to note that along with the Bills concerning special subjects which would require more than two-thirds of the votes of the Legislative before they may be passed, it is in contemplation that the existing laws relating to Native Lands, namely, the Native Land Trust Board Ordinance would be included in this category. We venture to say that in spite of the agreement reached between all the delegates in Fiji in April 1965, the United Kingdom Delegation indirectly brought the question of ownership of land and other allied matters for discussion before the Conference. The agreement was to the effect that the question of land should not form part of the Agenda of the London Constitutional Conference, that the ownership of land, be it native or otherwise, would not be challenged, and that as the solution to the problems concerning the security of tenure, renewability of leases was vital from the viewpoint of the economic life of all the communities in Fiji, these matters should be discussed freely in Fiji and agreed upon.

The substance of this agreement was, in our opinion, brought to the notice of Her Majesty's Government through His Excellency the Governor, and yet land was discussed at the Conference. We cannot for one moment accept the proposition that the existing Native Land Trust Board Ordinance ought not to be changed. On the question of Native land, we cannot help saying that neither the Government of Fiji nor the architects of the relevant Bill in 1940 have honoured their undertakings which were given to the Legislative Council. In addition, this Ordinance contains unjust and iniquitous provisions and its operation has not helped the country, let alone the Fijian owners and Indian tenants. If Her Majesty's Government proceeds with this aspect of the proposal as contained in the Final Report of the Conference, we can see nothing but ruination for Fiji. For this reason, we feel we must advise Her Majesty's Government that the question of the ownership of Native land may well have to be raised again.

We note that the purpose of the Conference was to bring constitutional changes in Fiji towards internal self-government. These proposals, in our view, move the Colony away from that goal and they are not in keeping with the United Kingdom's declared policy of leading her Colonies towards democracy and political independence.

Since the conclusion of the Conference, we have given serious and anxious consideration to the proposals and after long deliberation we have come to the view that we must reject them. 
It is our intention to oppose these proposals by peaceful and constitutional means. The implementation of these proposals, in our view, would create a grave racial disharmony leading to undesirable results. In this process an irreparable harm would be done to the country as a whole and we fear that goodwill, harmony and understanding, which has existed among all the races in Fiji over the last 90 years, would disappear forever. The responsibility for any course of events arising out of the implementation of these proposals would rest, in our view, on Her Majesty's Government. In the circumstances, we make this plea: that Her Majesty's Government take necessary steps to amend these proposals in consultation with the remainder of the Delegation and make an earnest effort so that a solution may be reached acceptable to all concerned. 



\section{Chapter 10: Independence Now}

Independence our only salvation.

A.D. Patel, 1968

I do not threaten anybody, and I do not fear any threats. My policy is to live and let live.

\section{A.D. Patel, 1968}

This Convention is firmly of the view that this country is fit and ready for political independence and requests the United Kingdom Government to convene a constitutional conference as soon as possible to prepare a democratic constitution based on one man one vote constituencies and transferring power to the representatives elected under such a franchise. The Convention emphasises the urgent need for immediate political independence in order to remove all political, social and economic impediments which obstruct the development of the country and thereby come seriously in the way of raising the standard of living of its inhabitants.

Ratu Mosese Veraeikete and Ratu Julian Toganivalu

Federation Party Convention, Ba, 29 June, 1968

'I, for one, believe that Fiji is ready for complete independence,' said A.D. Patel in late 1965. 'When we compare Fiji with countries like Samoa, Cook Islands, and other territories, no one can say that we are in any way backward to those countries. If they can shoulder responsibilities well, I do not see any reason why Fiji should not.' ${ }^{1}$ That became the standard platform of the Federation Party, and its principal manifesto in the 1966 elections held under the 1965 constitution. Political independence was one of Patel's main preoccupations. Another development which occupied him during this period was the negotiation for a new cane contract to replace the Eve contract of 1961. Then there were his duties as the leader of his party and his role as Fiji's first Leader of the Opposition. As if these were not enough, Patel was appearing in the most important criminal cases in the colony. Although his appearances before the Supreme Court had decreased in the 1960s, he was still Fiji's most successful living criminal lawyer. In addition, Patel was the Banaban people's chief legal counsel and advisor to the UN Committee on Decolonisation and had drafted their petition for independence to the United Nations. Patel's fame as a lawyer and as a champion of the underdog had spread throughout the Pacific. Semisi

1 Legislative Council Debate, December 1965. 
Koloamatangi of Nuku'alofa, Tonga wrote to Patel in June 1966 seeking his advice on a constitution for a Labour and Local Producers Union he was thinking of establishing in Tonga. Semisi wrote: 'I have heard a lot about you and your kind help to people who ask for it. You do not know me, but I have heard your name a great deal with your fame mentioned everywhere here in Tonga. That is why I write and ask your help in this matter.' ${ }^{2}$

Such a busy schedule would have taxed the energies of a much younger person, and Patel was in his early sixties. Besides, he was in indifferent health. Since contracting diabetes in the late 1950s, Patel had required daily injections of insulin. In September 1966, Patel became seriously ill, enough for the visiting Secretary of State for the Colonies, Fred Lee, to write to Patel wishing him speedy recovery because 'Fiji needed him.' In some parts of Viti Levu, the rumour spread that Patel had died, while the Fiji Times reported that Patel was preparing to leave for India for a visit. Patel was unwell but fully engaged. For his supporters, Patel's determination to continue on despite failing health was inspiring, an example to younger leaders to emulate. But there were others in the party ranks who wanted Patel to slow down, to delegate more responsibility. Perhaps some of them wanted their own little space in the sun, their own share of limelight, but the majority were genuinely concerned about Patel's health; they wanted him to be around and well when the next constitutional conference took place.

The first task for the Federation Party was to prepare for the elections, raising campaign funds, selecting candidates, educating the electorate about the issues. More complications were involved than might be apparent at first glance. The mechanics of voting was one, especially as there were many illiterate people voting for the first time. To assist them, Patel suggested using symbols on the ballot paper. That was the practice in many third world countries. The government refused. Writing to Patel on 19 January 1966, the Colonial Secretary objected on the grounds that a very large number of symbols for individual candidates would be required, making it difficult to distinguish between them if used on ballot papers. Then there was the question of deciding the basis on which to allot the symbols. Furthermore, 'their adoption would be regarded as retrogressive by literate persons and it would be necessary to make their use general and not confine them to Indians, not only to avoid charges of discrimination but to meet the requirements of cross-voting.' If symbols were used on separate ballot boxes for each candidate, an excessive number would be required to meet the needs of every candidate in each polling booth. Also the additional printing work might delay the elections. This was an issue on which the Fijian leaders might have been expected to agree with Patel. But that did not happen. Symbols would be used after independence.

2 In Patel's private papers. 
Another matter of importance was the strength and unity of the party. On the whole, the Federation Party was united, but there were dissidents among its members. This is revealed in an extraordinary, type-written letter a vice president of the party, acting on the instructions of the Working Committee, wrote to Patel on 6 August 1966. ${ }^{3}$ It is revealing because it indicates that the party members felt comfortable enough with Patel to approach him directly even though the matter they raised was extremely serious. 'This is the time to take stock of the record of the Party's Legco members without fear or favour,' the letter began. Patel had acquitted himself well of his responsibilities, despite his age and ill health, but they warned him that the 'time was fast coming, if not already come, that your responsibilities should be shared by others and relieve you of overwork.' Madhavan was praised 'for his unflinching work and loyalty,' as was Chirag Ali Shah even though he was a nominated member in the Council. The Federation member who came in for particularly severe criticism was Siddiq Koya whose 'rudeness to his colleagues and party workers and some others has by now become proverbial in the party and his insulting behaviour to some good workers of the Party has had demoralising effects on the Party workers and members.' He was susceptible to flattery. Apparently after returning from the London conference, ahead of Patel, Koya had said that 'we lost all and there should be left-wing and right-wing in the Party.' Comments like this had caused friction among the members. Unless this was corrected, cliquism would paralyse the party. The letter concluded that Koya should not be selected as a candidate unless his behaviour and attitude improved.

What Patel thought of the letter, and whether he was aware of Koya's reported conduct, is not known. However, at least two sources have confirmed a very tense encounter between Patel and Koya at a meeting in $\mathrm{Ba}$, so tense that they feared that party unity would be irrevocably damaged. ${ }^{4}$ Koya, who had made no secret of his disappointment with the outcome of the London conference whose failure he apparently attributed partly to his own party's intransigence, wanted to invite Andrew Deoki to a Federation Party meeting in Ra to explain his, Deoki's, position and why he had distanced himself from the Patel group. Patel rejected the request. It was a Federation Party meeting, he said, and since Deoki was not a member of the party, he had no right to insist on being invited. Deoki could call his own meeting to explain his position. Koya exploded and a heated exchange took place between him and Patel. He was not afraid of anybody, Koya said; he would show the people what he was made of. Patel responded in kind. 'No one rides roughshod over A.D. Patel,' he said, and if Koya wanted to challenge his authority, let him try. Koya walked off. But a few

3 This letter is included in the companion volume containing Patel's speeches and writings.

4 Conversation with Vinod Patel; the encounter took place in Ba. Dr Rod Alley of Victoria University of Wellington who talked with Patel at length and has made a fine study of the emergence of political parties in Fiji in the 1960s, has told me that he noticed a certain 'cooling off' in Patel's attitude to Koya. 
hours later, he returned and apologised to Patel for his rude behaviour, saying that Patel was like a father to him and that he would do anything for him. The two men were reconciled, but the warmth and closeness of earlier years was gone. Whatever Patel's own feelings, however, given the political realities and cultural politics in the Indian community together with Koya's performance in the Legislative Council, it was hardly likely that Patel would drop his lieutenant from the line up of candidates. It was critical for Patel to win all the nine Indian communal seats to consolidate his claim as the leader of the Indian community. To that end, it was essential to defeat those Indians who stood on the Alliance tickets and others who had opposed him in the past. The Federation team was predictably safe. Of the nine communal candidates, five were lawyers, one a wealthy landlord, one a farmer and two teachers. Looking at it another way, the communal candidates consisted of two Christians, three Muslims and four Hindus.

Immediate independence for Fiji on the basis of common roll was the platform of the Federation Party. The campaign slogan was 'Independence Our Only Salvation.' It was an intense campaign with its full share of electioneering fireworks. Once again, Patel was the target of particular attack. If the Federation Party were returned to the Legislative Council with increased majority, there would be violence and bloodshed in the country, because Patel had alienated the Fijians and Europeans. Patel was a dictator, his opponents charged, who wanted to become independent Fiji's first prime minister. Patel's response was Gandhian: 'I seek no power. All powers are corrupt. Whatever I do, I do with the co-operation of my comrades and my party members.' I aspire for one thing,' Patel told an audience at the Century Theatre in August, 'and that is the opportunity to serve humanity. To serve and not to rule. ${ }^{5}$

Patel was anti-European, Patel's opponents argued, intent on driving the Europeans out so that the Gujarati business community could flourish in Fiji. That, Patel said, was a wicked lie. How could Fiji do without European capital? He was not anti-European; he was against European domination of Fiji. 'We are trying to change them from sahibs into brothers and they resent it. They are all Christians and if they read the Bible sincerely and carefully instead of feeling angry at me or at the Federation Party, they will join hands with me and they will certainly say that this is what should be done.' Patel wanted the Europeans to take a wider view of their role in Fiji. 'The Europeans have to consider whether they are going to exercise these advantages [of better education and economic status] in the interests of the colony and in trying to make themselves leaders of the colony, or whether they are going to keep themselves into a narrow circle, always thinking in terms of their own small community and trying to look upon themselves as the opponents of other communities.' Those Europeans who knew

5 Pacific Review, 10 August 1966. 
Patel well denied that he was anti-European. J.G. Rodger, who had worked with Patel when he was the Member of Social Services, wrote: 'If A.D. was antiEuropean, I do not recall his ever showing it in my presence. But even if he were, why not? There were plenty of Europeans around at that time who made no secret of the fact that they were anti-Indian. ${ }^{6}$

What Fiji needed most of all for economic development was political stability, and Patel's brand of politics was destabilising the country, his critics charged. But what precisely did political stability mean? 'When they talk of political stability they seem to imply no political change, no change in the Government, no change of the Government. That is not the sort of political stability that anybody would desire or wish for in this country. Whether the outside investors like it or not we have had enough of colonialism in this country-for 90 years. What I understand by 'political stability' is where there is peace and order, where there is security of person and property and where there is rule of law. Governments might change, even constitutions might change, laws would change, fiscal policies would change from government to government and party to party but that does not mean that there is political instability.' The United Kingdom did not have a written constitution but no one accused that country of being politically unstable.

Fiji needed foreign capital, Patel agreed, but added that if the people of this country are to be free and happy, capital will have to be muzzled here, too, in the same way as in other countries.' If the foreign capital wanted to come to Fiji to pay lower wages to get higher prices and pay lower taxes, thus wanting to gain advantage from every source, he would rather go without that sort of capital. It would be better to proceed slowly, for the people to rise by their own boot straps. 'We welcome capital which wants to come in a spirit of give and take, in a spirit where both sides could benefit, not just to say that we have come to establish this factory and are giving employment to so many people, when they are paid only feed and breed wages, to tell the people that we have saved this country so much in foreign exchange when they sell their goods at higher prices than what this country would have to pay if they were imported from abroad or pay lower taxes and then say; look how much we are paying, knowing fully well that in their own country they would pay twice as much. When I advocated the rise in dividend tax from 5 per cent to 10 per cent, the vested interests of this country accused me that I was trying to frighten the future investors from outside, but they did not disclose the fact to the people that in their own countries they are paying as much as 30 per cent.' Often people asked the Federation to moderate its criticism because Fiji received aid from foreign countries, especially Australia and New Zealand. People were expected to be grateful for what they received, and indeed they were, Patel said, but they

6 Private communication 
were 'not prepared to say that it is altogether one-sided. At the best, such an aid on the part of the giver amounts to enlightened self-interest. At the worst, it amounts to self-interest. I will not say that we are not thankful to the Australian Government for giving us this gift of wheat, but I would certainly say that gift is like a cumin seed in the mouth of a camel. In view of what Australia gains and receives from Fiji, this gift is merely peanuts.'

Among Patel's strongest Indian critics in the Legislative Council was Andrew Deoki, who had been in the Council for more than a decade. To dislodge him from his Suva seat was, therefore, no easy task, for Deoki was an experienced politician, with wide social contacts. Putting another Indian male candidate against Deoki might not be enough, Patel reasoned. He gambled by putting up a little known India-born female teacher, Irene Jai Narayan, in the critical Suva seat. The gamble paid off, with Irene Narayan winning 5,676 votes to Deoki's 2,779. In Tailevu, young lawyer Karam Ramrakha won handily (3,220 votes) over K.B. Singh (677) and R.L. Regan (604). Patel's younger brother, also a lawyer, R.D. Patel, triumphed over James Shankar Singh by 4,704 to 4,41 1; Koya $(6,318)$ trounced Jaswant Singh $(2,221)$ and C.A. Patel $(19) ;$ M.T. Khan $(4,380)$ won over R.I. Kapadia (1,650) and B.D. Laksman (24); Chirag Ali Shah $(3,799)$ won easily over Alliance's Vishnu Deo $(1,955)$ and V.P. Vajpai $(770)$. In Vanua Levu, landlord Ramjati Singh $(2,328)$ won over lawyer Harish Kohli $(1,238)$ and James Madhavan $(5,049)$ defeated Andrew Gaya Prasad $(2,494)$. A.D. Patel himself won $(7,601)$ easily over his arch political opponent, Fiji National Congress Party and Kisan Sangh leader, Ajodhya Prasad $(4,025)$. Patel emerged from the election with his reputation enhanced and his party as the representative party of the Indian community.

After the elections, Fiji stepped into the next phase of internal self-government. Ratu Kamisese Kapaiwai Tuimacilai Mara, the leader of the Alliance Party, was elected the Chief Minister. Fiji now had a cabinet system of government. Patel became Fiji's Leader of the Opposition. In the three years that Patel occupied that position, a number of issues were discussed in the Legislative Council on which Patel made his contributions. Some of these concerned minor irritations, such as the restriction on women drinking liquor, which Patel opposed not only because such prohibitions were racially discriminatory-European women were exempt from the prohibition - but because they made little sense and were offensive to non-European women. To say that Indian women would start drinking if the drinking restrictions were removed 'is quite absurd and we are underestimating the sense of their responsibility, the sense of their dignity and pride that they take in their ancient culture.'

Patel supported the cooperative movement in Fiji but issued warnings about its pitfalls. The cooperative movement was a good movement, but very few such movements had actually achieved any success at all in Fiji. The idea behind 
establishing cooperatives was to prevent the exploitation of the consumer, but 'co-operative stores in themselves are no guarantee that the consumer will not be exploited,' Patel warned. 'If a private storekeeper exploits the consumer, or if a joint stock company exploits the consumer, the people working in the co-operative store can equally exploit the consumers, which they have been doing right throughout all these years in Fiji to the detriment of the movement and this has resulted in the failure of co-operative societies in the field of storekeeping. To make the movement a success, the government needed to give the undertaking that 'the farmers' faith and trust will be honoured,' otherwise 'this is all mere talk which leads to nothing.'

Patel spoke, as he had in the 1940s, on the right of the workers to unionise and strike, rights which the Alliance government acknowledged but tried to constrain through legislation. For Patel there was nothing wrong in unions resorting to political action to redress their grievances. 'It is well known throughout all countries that under the capitalistic system, the working class has to make great sacrifices resulting in continuous and constant agitation to assert the rights of the workers and have their share in all industrial undertakings. There is not a single instance in the world where they have managed to do it without resort to political actions. In this country, that seems to be the only remedy.' In India, which had often been criticised for its various real and alleged shortcomings, the workers used various tactics - gherao, dharana, bunds-lay siege and surround the management, until their demands were considered. If the workers did that in Fiji, the special constables would be called in, black-legs would be brought in to replace the striking workers, who themselves would be threatened with coercion and imprisonment. The workers had no minimum wage, and the conditions of employment were often appalling. So, 'to strike is a very important and valuable right of the worker,' but it was a right they exercised only when all other options had failed and not recklessly as the employers argued. If labourers in Fiji had not struck more in the past, it was 'not because they are contented, it is not because they are satisfied with the conditions and the wages they get, but it is because they feel helpless.' Employers frequently resorted to calling trade union leaders militant, but in Fiji, Patel said, a 'militant leader is a leader who stands for and insists upon fair play and justice, who refuses to be a tool in the hands of the employer and who stands firm. Whatever the colonial vested interests say, the salvation of the working class in this country will largely depend on the so-called militant and irresponsible leaders.' Ratu Mara disagreed. Economic development was of paramount importance, and he wanted maximum investment in the shortest possible time. As for trade unions, Mara said his government could not be accused of being against them. Still, labour is getting a fair share of capital investment here in Fiji, and while we are 
attracting capital we leave it to the trade unions themselves to argue their case and see that a fair share of the returns from the capital invested are shared by them.'

Throughout the 1960s, important changes were taking place in the system of Fijian administration. Partly as a result of outside pressure, among them the recommendations of the Burns Commission, the findings of academic experts, and partly out of internal re-thinking, the Fijian Administration of Ratu Sukuna's time was being reformed, and aspects of it rejected. In May 1966, Ratu Penaia Ganilau as Secretary for Fijian Affairs and Local Government, moved a motion in the Legislative Council to abolish many aspects of what by then had become a retrogressive institution. Gone now were separate Fijian courts, a Fijian magistracy, a Fijian constabulary, a Fijian divorce court, a Fijian Criminal Offences Code, sets of Fijian regulations applicable only to Fijians, separate Public Health Regulations, Provincial Prisons Regulations, and the like. Ganilau explained the reasons behind the change. The Fijian people did not want to be regarded as anthropological curiosities and a community different from the broad community in which they lived. They wanted to play a fuller part in the modern life of the colony, which could be achieved only through a thoroughly reformed and more democratic system of Fijian administration. Fijians objected to what Ganilau called 'cotton-wool legislation;' they wanted 'to tackle modern life by being allowed to face the hard facts of such life, free from paternalism, however well meant, and from especially protective legislation. ${ }^{7}$

Patel was cautious but direct. When the Fijian Affairs Board was established, the hopes of the Fijians had been raised high. They thought that they were the lucky section of the population because they were granted real self-government. It was hoped that in a decade or so, the Fijian people would gain valuable training 'in the arts and responsibilities of self-government.' But that hope was dashed. 'The taukei has not progressed very far, has not gained self-government and what is more, with this system he is not able to make very much headway in social, political and economic spheres.' The separate Fijian Administration and the Fijian Regulations had not only kept the Fijian people isolated from the rest of the population and from the mainstream of economic life of the colony, but had also placed on them 'the onerous burden of having to serve three masters - the Government of this country, separate Fijian Administration and the traditional rule of chiefs.' This Patel felt was counterproductive at a time when many Fijians were keen to enter not only the field of commercial agriculture but also the world of industry and commerce. This desire had always been there, though 'strained for a long time.' He urged the government to do something constructive.

7 Legislative Council Debate, 24 May 1966. 
Patel alluded to the Fijian Development Fund, created by Ratu Sir Lala Sukuna. Patel had congratulated the Fijian leader then. But the dream had vanished and the money wasted. 'I would have thought that with a Fund of that magnitude [£100,000 a year] the first thing that anybody would do would be instead of buying things locally and building houses, they would establish a house which would import materials directly, establish small scale industries which would process local material for utilisation and for the implementation of a development scheme, thereby not only saving money, not only making profits but also giving an opportunity for gaining necessary know-how and necessary skill in the fields of commerce and industry. We have a saying in our language. "That what the owner can see even in a broken piece of an earthen pot his neighbour cannot see in a clean mirror." I being the neighbour, if I cannot see what you can see, I would say good luck to the scheme; if you can make a success of it that way, do it. But I honestly feel there are better and more practical ways, and more profitable ways, of employing and using that Fund in the economic development of the taukei.'

Fijians had everything, yet they somehow remained poor, Patel said, like a man standing on the shores of a beautiful freshwater lake and complaining of thirst. They had capital which came from the Fund, collected from cess. They had land which was controlled by the Native Land Trust Board. And they had labour which was regulated by the Fijian Affairs Board. 'All these three, when properly adjusted and properly used, can lead a community to progress and prosperity. When all these three resources are neglected or not properly utilised, it leads to backwardness.' Sufficient land was placed in reserve for the Fijians, yet most of it had reverted to bush or was re-leased to Indian tenants under tenuous arrangements. ${ }^{8}$ Patel pleaded with the government to assist Fijians enter these fields, and offered cooperation. Why could not the Fijian landowners be given the title to their own land, to do with it as they pleased within some form of government oversight to check abuse and corruption? Why couldn't the Fijian landowners sell some of their land and buy out the CSR, thus gaining a valuable stake in an industry which was the mainstay of the colony's economy? ${ }^{9}$ What could be better than for the Fijians to become the millers of sugar cane and the Indians to be its producers? That would be true partnership between the two major communities.

To those who balked at embracing change, Patel responded that change was inevitable. 'Tomorrow will be different from today, because we already find that amongst the taukei now there are two schools of political thought emerging; one the conservative, the other progressive. One wants to hold on the past, the other wants to reach out for the future.' 'You cannot block the progress of

8 See Patel's contribution to the Legislative Council Debate on ALTO in 1966 and 1969.

9 Pacific Review, 28 January 1969. 
a people indefinitely. Everything changes; things will have to change in this country, and it will be the people who have vision, who have imagination to see that in the modern world only those can survive who have the ability to modernise. Those who have not will find that history is merciless and it cannot help them.' Patel contributed his own bit towards fostering change. In the 1960s, he provided legal advice to the fledgling Fijian Chamber of Commerce headed by Viliame Savu. Patel hoped that the Chamber would provide the launching pad for entrepreneurial Fijians, and even talked of forming a major Fijian company called the Taukei Pacific. But he died before much could be achieved. His successors did not continue Patel's unfinished business.

On a related note, during a Legislative Council debate on the Interpretation Bill in August 1967, Patel suggested that there should be a common name for all Fiji citizens, an issue that other leaders would champion later. This is what he said:

The Fijian under this definition does not connote the original inhabitants of Fiji. It is not an ethnic description of the Fijian people. It is widened to include people of other races who originally migrated from islands of the South Pacific. The Banaban is very much a Fijian under this definition as an original inhabitant of Fiji, so is a Rotuman, so is a Samoan, Tongan, Gilbertese, Ellice Islander, New Hebridean, so it is not a question of whether the word 'Fijian' designates any particular member of a particular race. It is a political designation given to a part of the Fiji population. Now, that creates a serious complication in my mind. If merely a section of the population is to be described as Fijians, how are all inhabitants of this country, as a nation, to be described. Whatever race a person belongs to - an inhabitant of New Zealand is called a New Zealander, whatever his race; an inhabitant of Australia is called an Australian; and of Great Britain, Briton. There are so many races in India but anybody belonging to India or an inhabitant of India is called an Indian. How shall the inhabitants of Fiji be described? It think it is high time now that the word 'Fijian' is kept for the inhabitants of Fiji irrespective of their race. If the original inhabitants of Fiji want to have a separate designation, I believe Fijian is not their original designation but their designation as they themselves described in their own language is taukei with pride. I would have thought that taukei would have been more appropriate for the Fijians as an ethnic description than calling them Fijians and including them with a number of other immigrant races who have come and settled in Fiji debarring the Chinese, Europeans and ourselves. There is a danger in this: once people 
get accustomed to the use of the world 'Fijian' as applied to certain races inhabiting Fiji, it psychologically comes in the way of the nationbuilding of this country. ${ }^{10}$

Two years later Ratu Mara resurrected and supported the idea. Patel was pleased hoping that agreements such as this might help 'create a peaceful and harmonious climate' at a tense time in Fiji. Thirty years later, however, Fiji still does not have a common name.

Two industries which came under serious scrutiny in the late 1960s were the gold mine and sugar. The Federation Party moved a motion in the Legislative Council to nationalise the gold mines, as the Fiji Labour Party would do two decades later, both unsuccessfully. ${ }^{11}$ His contribution to the debate shows Patel at his best. First he dissected the arguments against nationalisation. If the mine were nationalised, critics held, all prospecting would cease and the industry would be severely hampered. Patel disagreed. 'If gold industries were owned and run by the State instead of by private corporation, this State could carry on with the prospecting in the same way as a private corporation and perhaps much more effectively.' To the Attorney General's argument about difficulties in government acquiring the ownership of the industry, Patel responded: 'We are aware but once we agree and once we make up our minds that the gold industry would and must be nationalised, then I say, where there is a will there is a way, and constitutions all the world over are not so rigid and inflexible that they cannot be amended to meet the requirements of the country to a particular circumstance.'

Nationalisation would scare capital, the opponents of nationalisation argued, but Patel disagreed. Capital was not shy or timid, as his opponents argued. Shyness ordinarily arose from and was the offspring of morality and modesty. But, in truth, 'capital is a shameless, immoral, brazen dame who would travel and go to any length if there was monetary gain at the other end. Nothing is going to discourage it.' Britain had industrialised many industries yet that did not discourage hard-headed American investors from investing in that country. More British capital was pouring into India after India had nationalised several important industries. The gold mine was paying taxes and wages and employing people, it had even created a special town at Vatukoula. That was all true, said Patel, but 'I would be interested to hear how much of this profit they [the mining company] had ploughed back into the enterprise.'

Sakiasi Waqanivavalagi said that if the mine were nationalised the workers would be seriously affected, and they might even refuse to work for a statecontrolled mine. But Fiji had experienced several changes of ownership of

10 Legislative Council Debate, 29 August 1967.

11 Legislative Council Debate, January 1969. 
major companies and nothing had been said against them. Brown and Joske had been taken over by Carpenters, along with Morris Hedstrom. 'Now if nationalisation was effected in this industry all that it would amount to would be this. Instead of a small limited liability company, which in modern parlance is called a corporation, will be the largest and the strongest corporation in the country, namely the Government.' If the employees of Brown and Joske had no objection to being taken over by Carpenters, then Patel could not see any reason why the employees of the Emperor Gold Mines had anything to fear from government ownership of the gold mine industry. If anything, the workers would be in a better position 'because it is the duty and will remain the duty of Government to be a good employer. It will not be dominated by profit motives all the time at the expense of the employees. There will be no discrimination and the dissatisfaction which prevails in the working force would not arise because the Government would always see to it that there was no discrimination. And since it is the duty and the onerous obligation of the Government to provide as much employment for as many people as it can by economic development and the extending of those operations in the economic sphere as well as controlling and directing the existing ones with a view to better employment advantages they will be securer in their employment than at present.'

Patel then turned to why the gold mines ought to be nationalised. The central question was what was in the best interests of Fiji: to have gold mined by a private company for its own profit or by the government for the benefit of the tax payer. Gold was an important commodity in determining a country's political and economic position in international affairs. Its value might fluctuate, but as a commodity it would always remain important. 'It is one asset that is most important in international trade, both in times of peace and in times of war, and I for one would not call the Government of the United States of America or of the United Kingdom or President de Gaulle if they looked with alarm if there is some depletion in their gold reserves.' What phosphate was to Nauru, gold was to Fiji/ Patel said. Even before it became independent, Nauru had decided to nationalise the phosphate industry, a decision which benefited its people immensely. In the very first year of independence (1968), the Nauruans were in a position to financially help their neighbours in the South Pacific, including Fiji.

Unlike sugar and copra, the two other major exports from Fiji, gold was a limited, wasting asset. If the industry were nationalised, the Government could regulate its operations in such a way 'that the future generations are not totally deprived of the benefits.' Fiji could learn much from what was happening on the Ocean Island where a private concern, the British Phosphate Commission, was mining phosphate at such a rate that within a few years time, the island would 
be reduced to a 'desert of rocks completely unfit for human habitation. So one has got to be very careful about a very important and precious asset which is in the nature of a wasting asset, which cannot be grown or replaced again.'

One crop which could be grown and replaced again was sugar cane, the backbone of the colony's economy. Like gold, the sugar industry, too, was owned by an Australian concern. Since the 1960 strike, it had been organised along the lines suggested in the Eve report. The ten year contract between the Company and the kisan was about to end in 1970. Consequently, the new contract to be negotiated between the two parties became a matter of considerable debate and discussion in Fiji. The sugar industry had enjoyed a mixed fortune throughout the 1960s. In the early years of the decade, the weather conditions were good, production was high and cane prices went up as high as £4.17.6 per ton. Then things took a turn for the worse. In 1964 and 1965, Fiji was visited by two devastating hurricanes, and there was a drought in the sugar belt between 1964 and 1966. Earning from sugar declined, bankruptcies increased by 50 per cent, and sugar cane production declined by 30 per cent, while land rents increased dramatically, sometimes by 400-500 per cent. Petitions and motions were presented in the Legislative Council on behalf of farmers, pleading distress and hardship. Whatever their political affiliations and personal differences, almost everyone in the farming community agreed that the Eve contract was a killer as far as the growers were concerned. The impact and implications of the Eve contract would be brought before the Denning arbitration in 1969.

There were other related questions in the sugar industry as well which created much resentment among the growers. ${ }^{12}$ The machinery created to deal with the supervision of the sugar industry, the Sugar Advisory Board, was a facade of democracy, Patel argued, inefficient, ineffective, partial toward the company, distrusted by the growers, and 'designed to secure a strong representation of the millers and a weak sabotaged representation of the growers and workers.' The Governor would appoint five representatives of the millers in consultation with the General Manager of the CSR in Sydney, while he would select five from a list of ten submitted not by the growers' organisations, but by the foremen of cane harvesting gangs. It was absurd, said Patel, that a man elected for one particular purpose, to act as the foreman of the cane cutters and to see that the cane was properly harvested, loaded and delivered according to the program, should be presumed to represent the growers' voice in all respects in the industry. ${ }^{13}$ Lawyers and candidates for and members of the Legislative Council were ineligible for appointment to the Board. But this provision was nothing more than a tactic 'to create a false impression of impartiality.' Patel wondered

12 Legislative Council Debate, 8 May 1969.

13 Legislative Council Debate, May 1969. 
why such individuals were eligible to serve as Government representatives, but not as the representatives of growers and workers? Surely what was sauce for the goose was sauce for the gander. ${ }^{14}$

The ultimate effect of the Sugar Industry Control Bill, Patel argued, was to weaken the growers' position in the industry. Events proved him right. The chairmen of the Board were people who had little or no knowledge of the sugar industry at all. The first chairman, retired Air Marshall Sir Arthur Sanders, was appointed in January 1962, but left a year later. His successor, Justice C.C. Marsack, formerly the Chief Justice of Samoa, had no previous experience of Fiji or the sugar industry. Consequently and in the circumstances naturally, the officials of the Board relied on the Company for their knowledge of the industry. The growers paid the piper but they did not call the tune. In 1969, Patel moved a motion in the Legislative Council to have the Bill repealed. That paved the way for an independent arbitration into the sugar industry to settle the terms of the new contract.

It will be recalled that the Federation Party had accepted the 1965 constitution under protest, acceding to Anthony Greenwood's request to give it a fair trial. As it happened, the constitution produced the desired result for the colonial officialdom. A Fijian-dominated government with multi-racial trappings and image, headed by a high chief, had been elected into office. If things proceeded in the manner expected, Fiji would eventually be led into independence by the 'right' people, and Britain could honourably withdraw from the colony having fulfilled the terms and conditions of the Deed of Cession. In February 1967, Herbert Bowden, Britain's Secretary of Commonwealth Affairs, visited Fiji and said that the colony would not be hustled into independence. Britain would consider the request for independence only if it was the agreed wish of all the people of the colony. Fiji had a new constitution which was working well and should be given a fair trial. All in all, said Bowden, 'it is impossible to put down a time table. It is very much a matter for Fiji. ${ }^{15}$ Patel saw the trap that lay ahead. He told a meeting in Tavua: 'If we had gone on with the present undemocratic, unjust, iniquitous constitution, Britain would have played the same game with Fiji as it played with Rhodesia. When the time came for granting self-government, Britain would have said: "The 1965 constitution has worked well in Fiji." We would thus have been saddled with the present constitution forever.' ${ }^{16}$

Then, making matters worse, or rather rubbing salt on a deeply felt wound, the Alliance government began making unilateral decisions on important matters without consulting the opposition or even the Legislative Council. For Patel, the

14 Pacific Review, 30 November 1961.

15 Pacific Review, 15 Feb. 1967; Jagriti, 29 August 1968.

16 Pacific Review, 13 January 1968. 
same old pattern of racial imbalance existed. In the Council of Ministers, there were nine Europeans, two Fijians and only one Indian. This was no progress: 'This in a country in which Indians and Fijians are 94 per cent of the population and the European a mere 5 per cent? Is this democracy? Indians who are 50 per cent of the population are completely denied any share in the new government and are reduced to a permanent minority in the Council. ${ }^{17}$ The Federation Party, Patel said, had not been consulted by anybody about the introduction of the ministerial system of government which, contrary to what he had been told, was now beginning to acquire a seemingly permanent status. ${ }^{18}$

Unless there was definite progress toward a better constitutional framework, Patel said, his party would boycott the Legislative Council. His threat was taken seriously enough for Ratu Edward Cakobau, a man trusted and loved by both sides, to indicate to Patel through a Federation member (possibly S.B. Patel) the possibility of a meeting between Mara and Patel. Cakobau also mentioned a proposal that he had broached with someone on his own side. His proposal, a pro-tem compromise for the transitional period leading to independence, was that the Legislative Council should consist of 35 members of whom 15 each would be Fijians and Indians, and five Europeans, all elected on the communal roll. Patel discussed the proposal with his colleagues. Reportedly, Ratu Mara contacted Patel at his Nadi home. When the two met in Suva, Patel made a counter offer of a 40 seat Council, 15 each for Fijians and Indians, five for Europeans and five common roll seats with no racial reservation for either the voters or the candidates. Mara reportedly promised to give Patel a reply in due course, but that reply never came.

So on 1 September, 1967, Patel moved in the Legislative Council that:

undemocratic, iniquitous and unjust provisions characterise the existing constitutional and electoral laws of Fiji and their operation have caused alarm in the minds of right thinking people and have hampered the political advancement of Fiji along democratic lines and this House therefore is of the opinion that Her Majesty's Government of the United Kingdom should call a constitutional conference immediately to ensure that a new constitution is worked out and based on true democratic principles without any bias or distinction on the grounds of colour, race, religion or place of origin or vested interest, either political, economic, social or other so that Fiji may attain self-government and become a nation with honour, dignity and responsibility as soon as possible. ${ }^{19}$

17 Pacific Review, 5 July 1967.

18 Rod Alley 1973,181-182.

19 This quote and the others that follow are from the Legislative Council Debate, September 1967. 
Patel reminded the Council of his party's position at the London conference, and drew attention to the lop-sided composition of the House and flaws in electoral provisions and voting procedures all of which had worked to his community's disadvantage. Instead of bringing people together, fostering a feeling of compatriotism, it was widening the gulf among them. Patel said: 'Time has come when in the interests of democratic freedom, we have called for a halt. If this continues any longer attitudes will harden, difficulties will be created, the real aspirations and wishes of the overwhelming number of people in this country will be misrepresented abroad as is happening now, everybody who comes from outside will be told that we in Fiji like colonialism, we do not want freedom, nobody wants freedom. Racial attitudes will stiffen, the divisions will become still more rigid and defined and when the real time comes, people of this colony will find it almost impossible to break all these rigid barriers in order to unite the various communities of this country [and] lead them to nationhood.' Just how penetrating this prognosis was, subsequent history of Fiji would tragically confirm.

Patel's motion provoked one of the most intense debates in the annals of Legislative Council of Fiji. The constitution which Patel was rejecting was not undemocratic, said Ratu Mara; 'it was unassailable because of what it has achieved.' It was not iniquitous; it was inspiring. It was not unjust; 'it is unparalleled amongst emerging countries in the world today.' The Federation's behaviour, Mara said, was' wild, unreasoned, unfounded and childish.' But the main attack on Patel's motion was led not by Mara, or any other Fijian or European member, but by Vijay R. Singh, Minister for Social Services, signatory to the 24th of July document and a well known, implacable foe of Patel's. Singh was a member of a prominent Ba landowning clan. London-trained barrister, he was a sharp and eloquent, perhaps the best debater on the Alliance benches. Singh was at his fiery best. Patel was wrong and misguided, Singh said, and his fears about the deleterious effects of the communal roll vastly exaggerated. Despite the system of communal election, leaders of the different communities had been able to 'work in peace, harmony and in goodwill for the sake of the country and for the sake of the people.' The Federation preached one thing but practised another. To underscore his point, Singh told a joke about John and Mary. John asks, 'Mary, if you wasn't what you is, what would you be?' Mary: 'Why John, I would like to be an American beauty.' Then she asks John: 'If you wasn't what you is, what would you like to be? [puppet, puppet, interjected opposition members.] 'I would like to be an octopus.' 'Why would you like to be an octopus?' 'So I could put all my hundred arms around you.' 'John, you ain't even putting the two arms you already got.'

Singh pressed on. Patel was a stubborn prisoner of his own prejudices. 'He has this idea of common roll and with this idea he is in search of guinea pigs.' But the 
Alliance was 'not willing to allow the people of this country to be made guinea pigs so that [Patel's] ideas may be experimented with.' The Federation Party had called Singh a traitor, but the real traitor was A.D. Patel, Singh said. While others had risked their lives to defend Fiji, Patel was fighting the enemy from the 'security of his living room.' Patel was a wrecker. He talked incessantly about nation building but 'twice within the last quarter of a century he has brought this nation to the brink of economic disaster by running away from a conference table.' In the midst of this speech, the Federation members walked out of the Legislative Council chambers. As the Federation team were leaving - chased out by Singh's eloquent refutation of the Opposition's argument, according to Mara-Singh homed in. 'They were absent in 1943, they were absent in war and they are absent in peace. I wonder where they propose to fight the battles, the constitutional battles.'

Singh moved a counter motion of his own, expressing confidence in the 1965 constitution, expressing 'gratification [with] the repeated assurances of Her Majesty's government in the United Kingdom that there is no constitutional impediment to the progress of this country towards full internal self-government,' and noting that 'the transition to a ministerial system of government less than ten months after the introduction of the 1966 constitution is plain evidence of the ability of the Alliance Government to govern the nation with honour, dignity and responsibility and on democratic principles.' Singh was applauded by the Alliance for his spirited attack on the Federation Party. But Patel accused Singh of allowing himself to be 'used by his white masters to create a false image of the Indian community before the world.' Europeans in Fiji never soiled their hands with dirty work, they always employed Indians to do it for them. He was not a coward, Patel said of himself; he had never flinched in the face of threat or violence; he had even courted incarceration in gaol for his struggle on the growers' behalf. ${ }^{20}$

Patel wanted to test the strength of his stand in a by-election. He hoped to return to the Council with an increased majority, and a strong mandate for his common roll platform, which neither the colonial government nor the Colonial Office could then ignore. For a start, the Federation sent a long petition to the Colonial Office expressing no confidence in the Governor and asking for his recall. The petition outlined what it saw as collusion between the Alliance party and the colonial secretariat, the abuse of the public relations office engaging in 'obnoxious, misconceived and mischievous' propaganda against the Federation Party and the failure of the Governor and his senior staff to restrain vilification and provocative statements against the opposition. ${ }^{21}$ The reaction of the Colonial Office is unknown, but locally both the Alliance government as well

20 Pacific Review, 27 September 1967.

21 In Patel's private papers. 
as the colonial administration thought that boycott of the Council was a public relations stunt and that the Federation would eventually return to the Council of their own accord. They were mistaken. Patel was intent on going to the polls for a fresh mandate.

To succeed in that endeavour, Patel had to ensure two things. One was that the Federation should remain a united party and present a united front to the people. The bulk of the supporters were with Patel and behind the boycott decision, but there were others who differed with him. Among them was M.T. Khan, who had entered the Legislative Council in 1966 on a Federation ticket but who had subsequently resigned to stand on an Alliance ticket against the Federation's C.A. Shah. Others in the Indian community dissatisfied with Patel's style of politics joined the Alliance camp as its candidates, among them K.N. Govind, R.D. Mishra, M.V. Pillay, P.K. Bhindi, Dr Shaukat Ali Saheb, Andrew Gaya Prasad and Albert Jayant. The Alliance already had in its camp Abdul Lateef, Vijay R. Singh and K.S. Reddy. It was as formidable a line up of Indian candidates as the Alliance would ever get, but as we shall see, it was still no match for the Federation.

While consolidating his constituency, Patel also worked hard to bring more Fijians into the party to make it more multiracial. It was an uphill battle given the history of racial separation in the country. Patel was 'greatly mistaken,' said one Fijian letter writer to the Nai Lalakai, 'if he was under the impression that it would be an easy matter for the Fijian people to embrace the Indians and kick the Europeans aside. ${ }^{22}$ They would never do that, said a contributor to the Volagauna because it was the Europeans 'who have guided, educated and brought Christianity to our people and have patiently lifted our minds to a more enlightened state. ${ }^{23}$

The alliance between the Fijians and the Europeans was not simply an exercise in expediency, a temporary marriage of convenience; its roots went very deep. Perhaps Patel did not sufficiently recognise the depth of the feeling against the Indian community among powerful sections of the European and Fijian communities. But he was not one to give up. In 1968, he launched what came to be known as Operation Taukei to recruit more Fijian members into the Federation Party. Among those who joined the party as a result of this initiative were Ratu Mosese Veresikete, Ratu Mara's brother-in-law, the disenchanted half-brother of Adi Lala Mara; Apisai Tora, and Ratu Julian Toganivalu who became the party's organising secretary. Varasikete and Tora were charismatic characters with chequered pasts. Varasikete, for instance, had been a signatory, along with David Toganivalu, Emosi Vuakatagane, Peniame Naqasima and 
Serupepeli Naivalu, all studying in England in 1960s, to a hard-line Fijian letter to the 1965 constitutional conference which had proclaimed 'as emphatically and unequivocally as possible our desire that in such an event [self government] we, as the indigenous race of the Colony, must be granted the greatest share of political power.'

That was the only basis upon which the system of self-government would be acceptable to the Fijian people. Now, he was a part of the struggle to make Fiji independent. Whether it was a genuine conversion to the Federation philosophy, an act of personal rebellion against the Fijian establishment which had discarded him, or simply an act of opportunism, it is difficult to tell. But once in the Federation camp, Varasikete became an energetic and ardent member. Tora, likewise, had a chequered anti-Indian past; he, too, was a rebel with a mixed bag of causes, a loose cannon. Repudiated by the establishment, he sought succour in the Federation, injecting the word National into the Federation Party when his National Democratic Party merged with the Federation in November 1968.

As the country waited for by-election, tension mounted, exacerbated by certain incidents which only served to harden feelings on both sides. Some of these do not seem important with the passage of time, but they had their effect in the tense atmosphere then prevailing. One such incident involved the membership of a Fiji delegation to the Geneva Conference on Sugar in 1968. Mara wrote to Patel on 4 February inviting the Leader of the Opposition to accompany him to the conference, an invitation which Patel accepted on 21 March (a delay caused by Patel's hospitalisation from a heart ailment), and which the Governor formally announced on 29 March. Mara issued the invitation when the Federation Party was still out of the Legislative Council. According to Harish Sharma, the invitation was not genuine. 'It was not an invitation, it was a bait, it was an inducement for the nine members of the Federation Party to return to the Legislative Council.' When Federation stuck to its original plan, Mara withdrew the invitation. Mara's letter of 19 April read:

Dear A.D.

I am writing in connection with the International Sugar Conference in Geneva to which I invited you to accompany me in your position as Leader of the Opposition.

Indeed, the whole object of our discussion earlier this year was to re-establish the line of communication which should be maintained between the Chief Minister and the Leader of the Opposition and to try to get a bi-partisan approach on important matters like sugar.

Government has now been officially informed by the Speaker of Legislative Council that you did not attend the last two consecutive 
meetings of Legislative Council and that you have vacated your seat and are no longer an elected member of the Legislative Council and consequently no longer Leader of the Opposition.

In these circumstances it would be inappropriate for you to attend the International Sugar Conference at Geneva as part of the Fiji Delegation and I shall not therefore expect you to accompany me as had been previously intended.

Patel replied the following day.

\section{Dear Kamisese}

Received your letter of the 19th April, 1968 cancelling your invitation to me to accompany you to the International Sugar Conference in Geneva. I am not at all surprised.

To be candid, let me tell you that I had my doubt about its genuineness when you personally came to the Hospital to give me the invitation. I wondered whether it was given merely as a sop to induce me and my fellow members of the Opposition to give up our cause, to throw our principles overboard and attend the Council, when it was a matter of public knowledge that the Opposition was not going to attend.

So, to test your bona fide I accepted the invitation. I hope that you and the Colonial Alliance Government are now convinced that we are not out for sale. I am, on my part, satisfied that my suspicion turned out to be correct.

By cancelling the invitation you have relieved me from the strain involved in travelling by air to Geneva and carrying out duties and responsibilities of a prolonged conference which I would have felt in duty bound to undertake as the leader of the sugar cane farmers, in spite of my present state of ill-health. It has also saved me from considerable expense and loss of income during my absence from the Colony.

Further, your letter cancelling the invitation has afforded me sufficient proof of your credibility, for which I am thankful. ${ }^{24}$

If the Alliance leader had hoped to outmanoeuvre Patel and marginalise him in the discussion of an industry vital to Fiji's economic well being, he failed. His action only convinced the Federation followers of Alliance's unilateralism. The fact, as Koya said, that the Federation Party was outside of the Legislative Council did not mean that the party had ceased to exist. Whether inside or

24 Letter in Patel's private papers. 
outside the Council, Patel was without doubt the most knowledgeable man on sugar matters in the country. The Alliance had further rubbed salt into the Federation's wounds by appointing Andrew Deoki as the Vice Chairman of the Sugar Advisory Board. Deoki, based in Suva, had little direct experience of sugar cane farming, was a known Patel foe and had been defeated by the Federation in the 1966 elections. Relations between Mara and Patel, never really warm, cooled considerably.

On the hustings, the Federation explained why they had boycotted the Legislative Council. In meeting after meeting, the theme was the same. 'Smash the Constitution Before it Smashes You.' At a typical meeting at the Lilac Theatre, Patel said:

Our walk out from the Council and evacuating the seats under the Constitution has been the first step in that struggle. Some people called us cowards, some people called us runaways, some people just said that we forfeited, we lost our seats. We did not lose our seats. We willingly gave up our seats for one and one reason only, and that was to realise our goal as quickly as possible. You know the happiness and misery of the people of a country depend on its constitution. If you have got a just, democratic constitution, you are all happy because then every individual citizen, however small or insignificant he may be, is a sovereign in his own right. On the other hand, a loaded, lopsided, undemocratic constitution subjugates all the people for the benefit of the few and we have by now clearly seen what kind of constitution has been imposed on us. Our misgivings and our fears turned out to be true and now we are determined to smash that constitution to pieces. We are not going to rest until we achieve our goal. ${ }^{25}$

On the eve of the by-election, the Federation Party held its annual convention at Ba from 28 to 29 June. There, for the first time, the party launched its full manifesto. It is a document, written by Patel himself, outlining the programs and the philosophy of the Federation. Patel outlined the history of events, promises made and broken, that led to the boycott of the parliament. 'For 300 days we worked in the Legislative Council discharging faithfully our responsibilities as the guardians of the rights and interests of the people against the encroachments of those rights and interests by a government of despotic and greedy colonialists. Afraid to face us squarely in the debate, the Colonial Alliance Government made a practice of hastily using the guillotine. The Government thus deprived us of the basic and most important privilege of a legislator, namely the right of free and unfettered speech. Intoxicated with the power derived from a docile brute majority of yes-men in the Legislative Council, the government did not 
bother to consult the Opposition even on any important issue of bi-partisan national interest. The Governor, who enjoys ultimate, absolute power under the Constitution, ignored the Opposition completely even in such important matters as the introduction of the ministerial system. Without consulting or even mentioning to the Opposition, the Governor decided to set up a Council of Ministers on the 1st of September, 1967 which consisted of seven Europeans, two Fijian chiefs and one Indian in a Colony where Fijians and Indians form 94 per cent of the population and Europeans barely 6 per cent and the majority of whom are temporarily resident in the Colony in course of their employment in the Colonial Government and foreign European concerns.' With the Federation's 'cup of disillusionment full to the brim,' the Opposition staged its walk-out.

So what had the Federation Party to offer the people of Fiji? It looked 'upon the preservation and promotion of Fijian and Indian solidarity and unity as one of its most important tasks.' The recruitment of Ratu Mosese Veresikete as editor of Pacific Review and of Ratu Julian Toganivalu as Organising Secretary of the party, was a step in that direction. The Federation's aim was to create a national consciousness among the citizens of Fiji irrespective of race, religion, place of origin or sex and to make Fiji a democratic nation in which all citizens will be equal in the eyes of law, in which all citizens will enjoy equal political rights and have equal opportunity to advance according to their abilities. The Federation stood for a secular state and would 'follow the ideal of 'Unity in Diversity' by respecting cultures, customs and traditions of all races and through a secular state it will foster equal respect for all great religions of the world represented in Fiji as we firmly believe that all religions are various ways to reach the same God. The party was not anti-European 'but it is most emphatically against colonialism and supremacy of any racial group. ${ }^{26}$

The Federation Party wanted a justiciable Bill of Rights to protect individual and minority interests, would encourage rapid localisation of the public service, encourage local capital formation, control monopolies, abolish basic tax and other duties on the necessaries of life, nationalise the gold mines. 'The basic ideal of the Party is to make Fiji a welfare state in which no citizen however poor or incapable would have to go without food, clothing, shelter and medical care.' To that end, a Federation government would introduce old age pension and unemployment benefit schemes, and free education for primary and secondary levels. Trade union rights would be secured and local self government introduced in towns and townships. And, last but not least, the Federation Party would work for immediate independence for Fiji as a democratic republic within the British Commonwealth. In order to maintain the link with the past, an ethnic 
Fijian would be elected as the Head of State by a plebiscite every five years. To preserve connection with Great Britain independent Fiji will seek membership of the British Commonwealth.'

The Federation Party's manifesto was an important document because it was the first time in Fiji that a political party had outlined its vision for the country's future. For its part, the Alliance rejected Federation's program as unrealistic and unreasonable. Independence was premature. Ratu Mara set the tone. Leading a delegation on a goodwill tour of New Zealand in April 1967, he had said that except for a section of the Indian community, most people in Fiji were not keen on independence. 'We have a great deal to develop in our economy before we can successfully attain independence.' Mara warned the Indians to ponder carefully about their future. Voting for the Federation and embracing its policies would isolate the Indian community even further from the Fijian people. Less responsible Fijian leaders predicted violence if the Federation Party was returned with increased majority because Patel was against the Fijian people, especially their chiefs. Said Viliame Saulekaleka of Nakorotubu, Ra: 'Why hate our Ratus? Don't other people know that they are still our law. I do know some of us are against them some of the time, but don't be mistaken. They are Fijian.' Saulekaleka was not the only one who felt that way.

Patel's response was equally forthright. How could he be against Fijian chiefs when prominent chiefs, such as Ratu Mosese Veresikete, Ratu Julian Toganivalu and Adi Litia Lalabalavu were with the Federation? He added: 'One thing we all have to remember. If a Fijian chief, or for that matter any citizen of this country, wants to remain in the sanctimony [sanctuary?] of his own position, un-assailed by any public criticism, the political arena is the last arena he should think of entering. Once any person enters the political arena, he has got to learn to take the rough with the smooth as we all are doing.' One could not have it both ways. K.N. Govind, a sharp young Ba lawyer and Alliance candidate, summed up the feeling of those Indians who supported the Alliance. He, too, wanted to change the constitution, but instead of smashing the constitution he wanted to build it up and improve upon it. 'If one's kitchen is leaking, one does not smash the whole house to cure the leak. One merely repairs the leak.' Govind had got the whole thing wrong, Patel retorted. A constitution of a country should be likened not to a kitchen but rather to its foundational structure; even if the house had the best roof, the best kitchen and the best furnishings, if its very foundation was defective, it was better to demolish the house and start afresh rather than tinker with it and court certain disaster later.

To those who opposed immediate independence, and there were some in Patel's own community not to mention the Fijian and European community, Patel responded in a meeting of about five hundred in Nadi: 
Who does not want independence? Even the birds and animals want freedom. People who don't want independence are influenced by whites who do not want Fiji to become independent. The whites do not want the coloureds to be given equal rights. We want to make them brothers from masters and we will make them so. Some whites say that Patel wants to drive the whites out of Fiji. I do not accept this but do say that whites do not want to live with us with equal rights. When they live in this country, they will have to live with other races. They cannot be masters and we cannot be slaves. ${ }^{27}$

It was a tough and bitter campaign, marred occasionally by minor incidents of violence, but in the end, the by-election returned the Federation Party with all its nine seats with increased majority in all the constituencies. The Federation Party captured 46,960 of the total votes $(59,786)$ cast, while the Alliance managed only 12,826, with two of its candidates losing their deposits (by winning less than ten per cent of the votes cast in their constituency). ${ }^{28}$ The election was a personal triumph for Patel, who was returned with the biggest majority $(5,131)$ of the election. He won 7,903 votes to the Alliance's M.V. Pillay's 2,772. In the 1966 election, his majority was 3,576. The message was clear. 'The people have given their verdict in no uncertain terms, that the people of this Colony want freedom and equal political rights.' Patel could not be dismissed, dislodged or disregarded. The colonial government and the Colonial Office would have to deal with him. Mara was deeply upset; he felt betrayed. At first he had considered not contesting any of the seats at all, but had been advised by his Indian political confidantes that the Alliance stood a good chance of winning at least three Indian communal seats in Western Viti Levu. Unfortunately, this was not the last time that Mara was misled about his prospects in the Indian communal seats.

On the day the election results came out, Mara invited the Commander of the Fiji Military Forces, Frank Rennie, to a game of golf at Vatuwaqa. Rennie recalled the event: 'The Chief Minister, always a long hitter, belted the ball even further, and seemed to relish getting in behind it and striking it with vehemence. I wondered, as he smashed yet another ball almost out of sight, whether he was identifying each one with the personalities foremost in his mind. ${ }^{29}$ There was a lot on Mara's mind that morning. Fijian reaction to the Federation victory had been immediate: it was uniformly hostile. Protest marches were threatened, with what consequences no one could predict. When Rennie asked Mara what he intended to do, the Alliance leader replied: 'We might let things take their natural course for a while.' Then he departed for Lakeba and remained

27 Jagriti, 17 August 1968.

28 Fiji Times, 9 September 1968

29 Frank Rennie, The Regular Soldier, 286. 
incommunicado. Even Government House could not contact him. But with 'superb timing' he reappeared on the scene and seized the middle ground, 'stressing the vital importance to independent Fiji of multi-racial development.' It was a style and a tactic that the Alliance leader would use to great effect in later years.

While Mara was on Lakeba, Fiji seemed poised on the brink of racial confrontation. Three days after the results came out, Ratu George Cakobau convened a meeting of some 2,000 Fijians to gauge their response to the latest political developments. The Fijians did not want independence, the meeting heard..$^{30}$ All laws connected with leasing of native land should be tightened, the Indian tenants should be asked to vacate all Fijian land upon expiry of leases, and the Agricultural Landlord and Tenant Ordinance should be abolished. Another meeting in Suva on the following day, again some 2,000 strong, issued a statement that 'the control of the country should be returned to the Fijians, by force if necessary, and resolved unanimously against independence and common roll.' This sentiment was applauded thunderously at Vatukoula on 16 September and a resolution passed that 'ways and means should be sought to deport all Indians from Fiji.' The following day, some 6,000 Fijians attended a meeting of the Fijian Association, headed by William Toganivalu, Sakiasi Waqanivavalagi and Alipate Sikivou, all members of the Legislative Council, which reinforced the sentiments of the other meetings but added specifically that Patel should be deported.

On 27 September, Mara weighed in with his own assessment. The Fijian people, he said, felt 'betrayed and alarmed and intended to have their interests safeguarded.' ${ }^{31}$ Fijians had made so many concessions over land and other issues to the Indian community, at the expense of their own security. 'These moves were all made in the hope that they evoke a response which would compensate them by creating a society of mutual tolerance and respect. The Fijians now feel that their conciliatory attitude over the years will lead eventually to their relegation to the category of second class citizens in their own country. Let there be no violence, but let it be clearly understood that the Fijian people have spoken in no uncertain terms and they cannot and must not be ignored.' Three days later, the same message was conveyed in Ba when western Fijian chiefs, their faces daubed in black paint, led a procession through the sugar town. Waqanivavalagi dramatised the occasion by appearing in black (funeral) attire, 'to bury all his relationship to the Indian people.' Ratu Edward Cakobau regretted the incidents of threatened violence and offered this assessment which captures the dilemma facing the Fijian people in the 1960s succinctly:

30 For reports of these, see the Fiji Times, 12-17 September.

31 News from Fiji, XXI (40), 2 October 1968. 
I do not question the need for change for to stand still means stagnation. What I do suggest is that we have been carried along at too fast a pace-a pace not of our choice; a pace which has not given us time to take accurate bearings; and I suggest that it would not be a bad thing if all of us, Fijians and others, found out exactly where we are; become familiar with our present surroundings and try to chart some of the hazards ahead before pressing too quickly into the unknown. The Fijians have been overtaken by events which moved faster than was ever envisaged. Instead of gradual change, there has been rapid change. Many of the changes have come not in the past 90 years, but in 20 years, and most of them in the last decade. In particular, they have caught the Fijian people economically, educationally and politically unprepared..$^{32}$

Fiji had come as close to the brink of racial confrontation as it ever had, and it is tempting to hold Patel responsible for it. But confronting entrenched habits of thought is never easy or without cost. It took a massive struggle to send the message to the colonial establishment that the Indian community would not acquiesce nor tolerate enforced political subservience. It took enormous courage to take the stand that Patel did. The Indian demand for political equality could not be ignored. But as if to emphasise the point that he personally had nothing against the Fijian people, only against a system that had kept the two groups separated all these years, Patel moved a motion at the first sitting of the Legislative Council after the election, to 'provide ways and means to start the renovation of the island [of Bau] and to preserve its historical relics and monuments.' Mara supported it. It was a symbolic gesture of reconciliation that helped to heal wounds.

The by-election prodded the government to reconsider the timetable for the next constitutional talks. Jakeway encouraged both Mara and Patel to talk among themselves and to develop a common agenda. An Indian emissary, a Mr Hathi, had met all three during the course of a short visit to Fiji, and had encouraged the resumption of dialogue between the two leaders. In a letter to his son Atul on 11 August 1969, Patel wrote: 'I am meeting Mara tomorrow to find out if there is any area of agreement between us. If we come to some understanding, it is not still too late to have a conference in London perhaps in October. But let me not hastily predict. It is all in the laps of gods. Mara is the blue-eyed boy of the British. He is very cunning, as all Fijians usually are, perhaps more so, but our simpletons in Delhi are too obtuse to understand this or too indifferent to find out. Indians in Fiji and other colonies used to get some assistance from the Viceroy in their hour of need but since India has become independent, we 
have received no help or backing from India. From Indira downward, all are selfishly absorbed in the rat race for personal power and God help India! In such circumstances it would be idiotic of us to expect any help from that corner.'

The meeting did take place on 12 August 1969 under the chairmanship of Ratu Edward Cakobau. The Alliance Party was represented by Ratu Mara and Ratu Edward Cakobau, Vijay R. Singh, K.S. Reddy, H.W. Yee, David Toganivalu and W.M. Barrett, and the National Federation Party by Patel and Koya. At that confidential meeting, Patel dominated the discussions and set its tone. He reiterated the points he had been making throughout the 1960s. The constitution had failed, Fiji was ready for complete independence, there should be a strong Bill of Rights in the constitution, election should be on the basis of common franchise with some temporary reservation of seats to allay fears of the different communities; links with Britain should be maintained but an independent country had to secure its own security. Membership of the Commonwealth was no guarantee of permanent defence. 'Even Australia with a link with Britain during the second world war, felt Britain did not help her and after that as far as defence was concerned she looked more to the US.' It was a cordial meeting, an airing of views, though the gulf between the two sides remained. Patel wanted complete independence while Mara wanted 'full internal self-government.' By the time the committee met again on 3 November, Patel had died. 



\section{Chapter 11: The End in Harness}

We can build a grand edifice fit for free men and women to live with dignity, peace and prosperity.
A.D. Patel, 1969
Do not be afraid to face the difficulties ahead of us. When God gave us life, he expected from each one of us to face them, and not run away from them.

\section{A.D. Patel, 1969}

In his 1969 New Year's radio address, Patel spoke of the promises, challenges and opportunities that lay ahead. Fiji was likely to 'see most important political changes in the near future.' The challenge for the leaders and the people was 'to translate the fundamental human rights into a reality for all the people of this country regardless of race, religion, sex or origin,' to 'build a grand edifice fit for free men and women to live with dignity, peace and prosperity.' Another major challenge was to negotiate a contract with the CSR, a contract which, unlike the Eve contract, ensured a fair and just return to the farmers. Resolving these difficulties would not be easy. 'We have to strive to realise our aspirations. We cannot improve our standard of living unless we share what we produce equitably. Even with the most equitable distribution, unless we produce more, we cannot have much to share. Our prosperity largely depends upon purposeful and tireless endeavour on the part of all. It is intelligent work accompanied by thrift which makes individuals as well as nations prosperous. Let us not forget that our destiny is largely in our hands.'

Patel was at the centre of both these debates, indeed the driving force behind them. We have already seen his role in forcing the pace of political change in the colony, culminating in the negotiations which would eventually lead Fiji to full independence. People have speculated about what Patel might or might not have done, and whether the independence constitutional settlement might have been different had he been alive and at the helm of National Federation Party leadership. The question is moot but there can be no doubt that Patel would not have compromised on common roll, an idea to which he was intellectually and politically committed throughout his life. He would have insisted on its introduction, even in a limited form. But that was not to be. After his death, the party he had established and led fractured, factionalism developed, personalities clashed and the political ideology upon which the party was founded disappeared into the background as the politics of ethnicity and communalism dominated the public agenda. 
When Fiji became independent on 10 October 1970, the occasion was celebrated with appropriate dignity and splendour. Foreign dignitaries from several commonwealth countries witnessed Prince Charles hand over the independence instruments to the new Prime Minister, Ratu Sir Kamisese Mara, knighted the previous year. But these dignitaries and other guests did not hear a single word about Patel and his role in the independence movement. They could be forgiven, for the glossy independence brochure, containing the official program of the festivities, made no mention of the NFP leader, although the names and pictures of others, such as Vishnu Deo and Ratu Sir Lala Sukuna, adorned its pages. Neither of these two great leaders, distinguished for their achievement in other fields, had participated directly in the discussions which led to independence. Indeed, by the 1960s, both had departed the political scene. It was left to Ratu William Toganivalu, one of Patel's more persistently hostile political opponents, to ask at the first sitting of the new parliament why Patel's picture had been omitted from the official program. The omission was not an oversight. A decade later, Alliance government minister Ahmed Ali, in a foreword to a short general history of Fiji by Australian academic Deryck Scarr, noted the contribution of many public figures, among them Vishnu Deo and Siddiq Koya, but Patel was once again missing from the gallery of Fiji's notable public figures. Ali's amnesia is understandable in the light of his subsequent public career.

We now turn, finally, to Patel's last battle. Fittingly enough, it was with the CSR. At long last, the government had agreed to the appointment of an independent arbitrator to settle the terms and conditions of the new contract between the growers and the Company. Lord Denning, Britain's Master of the Rolls, was the independent arbitrator. His name was suggested by Patel, who was now the Federation of Cane Growers chief counsel. The CSR was represented by Ronald Kermode and the Kisan Sangh by Gerard Brennan, a brilliant Australian lawyer intimately familiar with the workings of the Queensland sugar industry. According to Karam Ramrakha, who was one of the Federation team of lawyers, along with R.D. Patel and Siddiq Koya, Patel exuded quiet confidence, telling his colleagues, prophetically as it turned out, that this would be his last fight with the CSR.

The arbitration began on 19 August 1969. Denning was asked not only to determine all issues over the new contract between the growers and the millers, but also to settle 'the terms which will be just and equitable and fair to all parties.' Patel went first, which was unusual. In Brennan's view, the CSR should have opened the proceedings for it was they who were defending the old contract. But for Patel, the dispute was as much a contractual matter between two parties as it was a political issue. The two were historically linked. In his submission, Patel put his by now familiar case against the CSR. Patel rejected the Eve contract which he called a 'killer contract,' that was pushing the growers 
deeper and deeper into indebtedness. More bankruptcies had been filed during the life of the Eve contract than ever before. He spoke about the uneven contest between a giant monopoly and largely illiterate and divided growers. He told Denning about the CSR's secretive accounting practices which left the growers completely in the dark about costs of production and related matters. $\mathrm{He}$ wanted an opportunity to examine the company's accounts to verify company deductions and to reveal the 'concealed profit' the CSR was alleged to have been making. And Patel asked for a fairer sharing of the cake between the millers and the growers. The current practice of lump sum, flat price method - which Patel described as the most primitive method in the world - would have to go, replaced by a basic price and sliding scale linked to the price of sugar, including the price of the by-products such as molasses.

Denning agreed with Patel on most matters. The Eve formula was complicated, beyond the comprehension of most lawyers, let alone the poor illiterate grower. The CSR's own lawyer, Kermode, agreed on this point. There was no equal partnership between the millers and the growers. 'The millers had all their costs covered while 'the risk of loss is all on the growers. None at all on the millers; or, at any rate, none to speak of.' Denning could 'see no justification for the way in which the Eve formula treated molasses. It was and is a valuable product from the cane. And in any formula the value of it should be brought in as part of the proceeds.' About costs: 'Suffice it to say that the growers were much aggrieved because they were never given any information and were obliged to accept the "certified proceeds" and "certified costs" without question. I think their grievance was genuine and was justified. The costs were certified at a higher figure than they should have.' Denning pointed to many other areas in which the Company had taken unfair, though properly legal, advantage of the Eve contract: in the re-evaluation of its assets ('It is one thing for a Company, in making up its accounts, to make an allowance of 3 per cent for depreciation of its capital assets. It is quite another thing to take that sum in hard cash and take it out of revenue'); in the way its Head Office expenses were deducted ('The amount to come under this head and under other heads was very ill-defined'), and the way the unit costs of production were dealt with ('I cannot help feeling that they might have done more to reduce the "unit costs" if they had some incentive to reduce costs. But under the Eve formula there was no incentive. They got all their costs anyway out of the proceeds').

Denning rejected the Eve formula, recommending a new contract that gave the growers 65 per cent and the millers 35 per cent of the proceeds of sale, each paying their own costs, instead of the 57.75 to 42.50 ratio of the Eve formula. The sale, Denning said, should include not only sugar but also the proceeds of molasses and other by-products, as the farmers had demanded all along. The growers were also given the power to appoint an independent accountant to examine the 
books and accounts of the millers, something which the company had always successfully resisted. Finally, the growers were to receive a guaranteed minimum price of $\$ 7.75$ per ton of cane, $\$ 5.75$ paid within five weeks of delivery and the remaining $\$ 2$ within six weeks of the end of the crushing season.

Denning was not Eve, as the following passage from his report so clearly indicates:

During all these years the costs of the millers have been recovered, they have received considerable contribution to their capital improvements and, in addition, they have a good reward. They have not gone short. But the growers have. In settling the terms of the new contract, I have tried to restore the balance. I have tried to give the growers the reasonable remuneration which the Commonwealth Sugar Agreement intended that they should have. I hope this will not deter the millers from continuing their good work for Fiji and for the sugar industry in Fiji. The great public companies of today owe a duty, not only to their shareholders to make a profit, but to the people among whom they live and work, to do their best for them. Every responsible shareholder recognises this. If the sugar industry in Fiji is to prosper, the bitterness of the past must be removed. Growers and millers must work together in a spirit of mutual trust and good will-as befits partners.

Partnership, mutual trust and good will, fair remuneration, the social and economic responsibility of the companies: these words reverberate in Patel's speeches. This is what he had been fighting for since the 1940s. There is no doubt that Patel would have been deeply satisfied with, and felt his stance in the sugar industry vindicated by, the Denning report. Certainly Denning was fulsome in his praise of Patel. A man so severely criticised by Trustram Eve as a dangerous self-serving opportunist was praised by Denning who wrote in his report: 'He was an accomplished advocate who presented admirably to me the case of the Federation.' In his letter to me of 20 January 1990, Denning expressed the full extent of his admiration for Patel. Speaking of Patel's influence on the arbitration proceedings, Denning wrote:

Of all the lawyers who appeared before me, A.D. Patel was outstanding. He even out-shone Mr Brennan [now the Chief Justice of Australia]. He was a master of all the facts and problems of the sugar industry in Fiji. He presented them with skill and understanding. It was his persuasive advocacy that led me to my report which was in favour of the growers and against the millers.

These warm words of appreciation would have been reassuring to a man often reviled by his opponents as a greedy Gujarati exploiting illiterate cane growers 
for his own political ends. But Patel did not live long enough for that, nor for the completion of the arbitration proceedings. Patel had been unwell throughout, several times asking Denning permission to remain seated while cross-examining CSR witnesses. He suffered a heart attack on 3 September, two weeks after the arbitration began. It was left to his fellow Federation lawyers Koya, Ramrakha and his younger brother R.D. Patel to sum up the Federation's case.

Patel was admitted to the Lautoka hospital where he remained for the next three weeks. Doctors worked hard to resuscitate his health which suffered from numerous complications, including diabetes, high fever and pneumonia. A very concerned Siddiq Koya was on hand. He and Karam Ramrakha immediately contacted Karam's older physician brother Shiu and briefed him on Patel's medical history. Shiu promised to contact Joe Cassidy, the colony's heart specialist, and Koya wanted Cassidy to come to Lautoka for a second opinion. Koya asked Patel not to get unduly worried about his health. Dr Sorokin had told him that Patel was on the way to full recovery. 'We are all standing by and if there is any further news, we shall let [you] know immediately.'

Messages of sympathy and support from colleagues and friends poured in. Denning himself wrote an informal hand written note to tell Patel that he, 'A.D.' (which was how Denning addressed Patel), had been conducting his case admirably, urging him to take a good rest 'so as to be quite fit again.' Charles Gurd, the colony's Director of Medical Services, wrote as only an old medical friend could write. 'The news is good and you are making a good recovery. I do hope you won't be tempted to take any chances with yourself.' 'Remember that A.D.', he admonished Patel. Justin Lewis, the Attorney General, wrote to Patel enquiring about his availability for forthcoming meetings of the Working Committee on Landlord and Tenant matters, but having himself once suffered from a collapse from overwork, advised Patel to take as long a rest as he needed. Chief Justice Sir Clifford Hammett, too, wrote to Patel two days after he was stricken. It was a touching note from a concerned friend:

Please do take care and rest and do what the doctors advise. You have given your best for your side in the Arbitration and can safely and confidently leave it to your lieutenants to represent your views in the closing stages of the proceedings. You must rest and get well for your counsel and advice and wisdom and restraint will be in much demand in the coming year and you must be fit to meet the demands that will be made on your physical resources.

Other close friends advised the same. His family was naturally distraught. Some of their anguish and frustration is evident in Pratibha Patel's letter which Patel received on 19 September. Pratibha was then a sixth form student in Sherbourne, Dorset. She advised her father to give up politics. 'You have done 
as much as anyone can and no one appreciates it. Why are you killing yourself for them? Take my advice and give it up. You have got your law practice and us five children to look after. That's enough! I wish you would take a long, long holiday somewhere away from Fiji. If only I was at home, I think I would force you to!!' Then she remembered to tell what she had been up to, and the sort of news dad always liked to hear. She had been out with some friends for the school holidays. She was taking A-level History and English and would be restarting with Latin the next term. She was playing badminton this term and expected to play Lacrosse as well. The previous night she had watched the epic Agony and Ecstasy. 'It was a marvellous. I have only read half of the book, but it is wonderful. Don't you think so?' And she remembered the weather, a subject of perennial interest to her father. 'Autumn is definitely here. The leaves are turning red and gold, and of course it's misty and getting cold.' This was the kind of letter Patel enjoyed receiving from his children. But in the end, Pratibha's plea was the same: 'Please, please, give up politics for our sake. If I mean anything to you, please give it up.'

After three weeks at the Lautoka hospital, Patel was discharged on 26 September. He returned to his home in Nadi to recuperate. He wrote to his distraught children to promise them that he would take a long break away from his hectic public life. But even while recuperating, Patel had duties to perform. To a large extent, Patel was the victim of his own success. As an accomplished orator knowledgeable on a variety of subjects, Patel was a much sought after public speaker. People would travel miles to listen to his discourses on culture, religion and philosophy. In 1969, he was asked to speak on the centenary of Mahatma Gandhi's birth at the Old Town Hall in Suva. Ratu Sir Kamisese Mara was to be the other speaker at the function. Mahatma Gandhi was Patel's idol, and so the question of declining the invitation did not arise, the advice of the doctors for a complete bed rest notwithstanding. 'I cannot resist to pay my humble tribute to the Great Father who has guided my footsteps and saved me from many pitfalls in life.'

Patel's tribute is a sombre reflection on humanity. In his New Year's address, Patel had spoken about the strife in Vietnam, Nigeria and the Middle East, lamenting the failure of human beings to match their wonderful achievements in science and technology with the wisdom in their relations with each other. He returns to that theme in this passage:

In spite of great strides which a portion of mankind has made in science and technology, in spite of man becoming a visitor of moons and stars, in spite of some countries' possessing the power to wipe out life from the planet, we are living essentially in the age of great pollution. Our atmosphere is polluted by nuclear fall outs and poisonous discharges which engines and machines are emitting ceaselessly day and night on 
the land, on the seas and in the skies. Our air is polluted, our waters are polluted and so is our land and what grows on it. The machine has become the master and man its slave. In this world of mental, moral and spiritual pollution, Mahatma Gandhi was a great purifier, who had adopted the path of non-violence, advocated social reform to abolish untouchability and the barriers of caste, and who had placed before the people 'his own example of simple living and high thinking and selfless service.'

Patel talked about the Mahatma's many setbacks and disappointments. Nonetheless, he continued to live in the hearts of the oppressed and the downtrodden giving them hope and inspiration and courage to face arrogant oppressive power with their knees unbended and their heads held high.'

A few hours after completing this speech, A.D. Patel had a massive heart attack and died around eleven at night on Wednesday, 1 October. As the news of his death spread through the night, friends and relatives converged on his house in Nadi. The following day nearly all the Indian-owned shops in all the major towns remained closed. On Friday, all primary and secondary schools in the Nadi area were closed. Some schools in other areas also closed and some held prayer meetings before closing. Meanwhile, thousands of people began arriving in Nadi in hired trucks, buses and cars. Unable to find accommodation, people set up open air tents, while others slept in their vehicles near the Wailoaloa crematorium.

Patel's body lay in state at the Nadi Civic Centre from Thursday as people lined to pay their tribute. Prayers were said and speeches made, too, by members of all the faiths, Hindu, Muslim, Sikh, Christians. Throughout the three days the body lay in state, Fijian mourners from a nearby koro kept vigil by beating a Mi regularly at ten minute intervals. One eye witness remembered 'the steady cadence of the Mi' which 'had a powerful psychological effect for, like the peculiar, sombre-looking shrubs growing on chiefly graveyards, it kept reminding [the mourners of] the atmosphere of death,' proclaiming the end of an era.

By mid-day on Sunday, Nadi was packed with a crowd estimated at around twenty thousand, with several thousand more lining the three and a half mile route to the beach-side crematorium at Wailoaloa. Patel had wanted his cortege to be drawn by a pair of bullocks, but that request was now impossible to honour. He would have to make his last journey, draped in the red and green flag of the National Federation Party, on a machine - an open truck piled high with wreath and flowers - about whose polluting effects he had written just before his death. At the crematorium, Fijian pall bearers, dressed in black and white, placed the coffin on a funeral pyre piled high with logs. Bhaskaran Iyer, a Hindu priest, and longtime companion in prayer meetings in Nadi, led the prayers at 
the end of which Atul, Patel's eldest son who had arrived back from England just a few hours earlier, performed the final rites and lit the funeral pyre. The crowd heaved and cried at the end of a remarkable journey of a remarkable man. Patel had died as he would have wished, in harness and in the course of duty.

Patel had lived all his public life in the midst of issues which generated great controversy, especially in the sugar industry and in politics. He was not a man to walk away from a fight if he was convinced that he was right or if a matter of great principle was at stake. All his political opponents felt that Patel was unduly stubborn on the issue of common roll. They all agreed that the idea was fine in principle, but common roll could not be introduced in Fiji immediately because, or so they said, it would lead to Indian political domination. But however much they disagreed with Patel's politics, they all agreed with Ratu Mara that Patel 'had personal qualities deserving of the utmost respect,' a man 'who set a standard of dignity and courtesy worthy of the highest parliamentary traditions.' Sir Vijay R. Singh, perhaps Patel's most bitter political opponent, recalled with admiration: 'The whole of Fiji became his constituency for the last nine or ten years. Mr Patel was one of the most eloquent speakers of the country and it was for me a pleasure to hear him expound his views in his own persuasive inimitable style. We admired the eloquence, the clarity, and the occasional emotion as well as the ready wit that he brought to bear during debates. In the last discussion we had with Mr Patel, he said he desired to see the people of this country of different races united into one nation.'

The need for an overarching national consciousness in a racially divided Fiji, lay at the heart of Patel's political philosophy and struggle. He disagreed with those who wished to construct a political order on the foundations of primordial values of ethnicity and race. For Patel, [Nationalism] is a question of the mind, not a question of the colour. There is one sentence of the Bhagavad Gita which is very appropriate. The sentence says: 'All creatures are bewildered because knowledge is covered with ignorance. Remove the cover of ignorance, and knowledge shines. It is the same with our nation, covered with the ignorance of racialism and sectarianism. Remove the cover and the nation is there.' But in the history of post-colonial Fiji, it was racialism, or communalism to call it by its gentler name, that formed the foundations of the new political order. The independence constitution was basically an extension of the 1966 constitution which Patel had denounced as iniquitous, unfair and unjust. IndoFijians had parity with the Fijians, where each group had twenty two seats, but the General Voters were grossly over-represented, with ten. Communal as well as cross-voting seats were retained, both of which Patel had rejected. And the country went into independence without an election. The National Federation Party had extracted a promise from the Alliance that the electoral arrangement negotiated at independence would be an 'interim solution' to be 
examined by an independent commission which would recommend the best method of election for Fiji. A Royal Commission, headed by Professor Harry Street did make recommendations for Fiji to move towards common roll on the basis of single transferrable vote, but the Alliance was in no mood to listen. The independence constitution had worked for the party and put it in power by a good majority. By then, the NFP, too, had begun to have doubts about common roll. In the upshot, the Street report was not even debated on the floor of the House, something which Patel would have never countenanced.

A part of the problem was Siddiq Koya himself, Patel's successor as the Leader of the Opposition and the NFP leader. The ebullient, chest-thumping orator was not quite able to capture the loyalty and trust of his colleagues and followers. His hold on the party machinery was tenuous, the loyalty of party stalwarts conditional. Personal ambitions aside, Koya's own erratic performance contributed to the problem, in particular his fraught relationship with Mara. Factions developed, egos were wounded, leadership challenge appeared, and disenchanted party faithfuls began looking for other alternatives, the Fiji Labour Party, formed in 1985, being one. The NFP was not the same tightly-run ship it had been under Patel. It was not until the late 1980s that the party managed to regain a semblance of its former unity under the leadership of Jai Ram Reddy.

Meanwhile, the ravages of communalism began to take their toll. Virtually every public issue of significance came to be viewed from a communal angle. Race, it was said, was fact of life. Sadly, it began to become a way of life. Politics polarised along racial lines. The Alliance Party had been in power for a generation, and many of its leaders and supporters began to view government as their natural domain, their natural right. The inevitable happened when the government did change in April 1987. A military coup removed the democratically elected National Federation and Fiji Labour Party Coalition. Three years later, the country was decreed a constitution that entrenched racial segregation in the electoral system, removing all opportunities for cross-racial politics and providing every incentive for ethnic chauvinism and extremism. Fiji was racially polarised as never before.

Had one man's lifelong struggle for a just, fair and non-racial Fiji (One Country, One Nation, One People) come to nought in the cul-de-sac of racial compartmentalisation? Were the people he once led destined for a life of permanent political subservience in the land of their birth? Only time will tell. But, perhaps, the people of Fiji may in time come to appreciate the truth that in the affairs of state, there is often another way especially if, as A.D. Patel used to say in his campaign rallies in the 1960s, responsible leaders of the nation thought less about the outcome of the next election than about the future of the next generation. 



\section{References}

Alley, Roderic 'The Development of Political Parties in Fiji', (Victoria University of Wellington, PhD Thesis, 1973).

Andrews, C.F. and Pearson, W.W. Indian Indentured Labour in Fiji (Calcutta, 1916).

Basham, A.L. The Wonder That Was India (London, 1959).

Belshaw, C.S. Under The Ivy Tree: Society and Economic Growth in Rural Fiji (London, 1964).

Bhandarkar, Sir R.G. Vaisnavism, Saivism and Minor Religious Systems (Varanasi, 1965).

Billimoria, Purusottama 'The Arya Samaj in Fiji: A Movement in Hindu Diaspora', Religions (1985), 15:103-129.

Burns, Sir Alan Report of the Commission of Inquiry into the Natural Resources and Population Trends of the Colony of Fiji (Suva, 1960).

Burton, J.W. The Fiji of Today (London, 1910).

Chapman, J.K. The Career of Sir Arthur Hamilton Gordon: First Lord Stanmore, 1829-1912 (Toronto, 1964).

Davidson, J.W. 'Constitutional Change in Fiji', in Journal of Pacific History (1966), 1:165-182.

de Bary, William Theodore Sources of Indian Tradition (New York, 1958).

Derrick, R.A. A History of Fiji (Suva, 1951).

Eve, Sir Malcolm Trustram Report of the Fiji Sugar Inquiry Commission (Suva, 1961).

France, Peter Charter of the Land: Custom and Colonization in Fiji (Melbourne, 1969).

George, T.P.S. Krishna Menon:A Biography (London, 1964).

Gillion, K.L. Fiji's Indian Migrants: A History to the End of Indenture in 1920 Melbourne, 1962).

Gillion, K.L. The Fiji Indians: Challenge to European Dominance, 1920-1946 (Canberra, 1977). 
A Vision for Change

Hardiman, David Peasant Nationalists of Gujarat (Delhi, 1981).

Kelly, John D. A Politics of Virtue: Hinduism, sexuality and counter-colonial discourse in Fiji (Chicago, 1991).

Kessinger, Tom Vilyatpur: Social and Economic Charge in an Indian Village, 18481948 (Berkeley, 1974).

Kumar, Ravinder Western India in the 19th Century (Canberra, 1968).

Lal, Brij V. 'An Uncertain Journey: The Voyage of the Leonidas', in Journal of Pacific Studies (1982), 8, 55-69.

Lal, Brij V.Girmitiyas: The Origin of the Fiji Indians (Canberra, 1983).

Lal, Brij V. 'Kunti's Cry: Indentured Women on Fiji Plantations', in Indian Economic and Social History Review (1985), 22:1, 55-71.

Lal, Brij V. 'Veil of Dishonour: Sexual Jealousy and Suicide on Fiji Plantations', The Journal of Pacific History (1985), 20, 135-155.

Lal, Brij V. Broken Waves : A History of the Fiji Islands in the 20th Century (Honolulu, 1992).

Lal, Brij V. 'The Odyssey of Indenture: Fragmentation and Reconstitution in the Indian Diaspora,' Diaspora: A Journal of Transnational Studies (1996) 5:2, 167-188.

Legge, J.D. Britain in Fiji, 1858-1880 (London, 1958).

Lowndes, A.G. (ed.) South Pacific Enterprise: The Colonial Sugar Refining Company Limited (Sydney, 1956).

Meller, Norman and James Anthony Fiji Goes to the Polls. The Crucial Legislative Council Elections of 1963 (Honolulu, 1968).

Menon, K.P.S. Many Worlds: An Autobiography (Clarendon, 1965).

Moynagh, Michael Brown Or White? A history of the Fiji sugar industry, 19731973 (Canberra, 1981).

Narsey, Wadan L. 'Monopoly Capital, White Racism and Superprofits in Fiji: A Case Study of the CSR', in Journal of Pacific Studies (1979), 5-106.

Pocock, David Kanbi and Patidar: A Study of the Patidar Community of Gujarat (London, 1972). 
Potts, J.C. An outline of the successful development of the small farm system in the Fiji sugar industry', in Transactions and Proceedings of the Fiji Society, 9 (1962-63), 26-38.

Prasad, Ajodhya Kisan Sangh Ka Itihas (Rajkot, 1962), 2 volumes.

Prasad, Kamal Kanta 'The Gujaratis of Fiji, 1900-1945: A Study of an Indian trader community' (University of British Columbia Ph.D dissertation, 1978).

Ravuvu, Asesela Fijians at War (Suva, 1974).

Rennie, Frank The Regular Soldier (Auckland, 1986).

Rutherford, Noel 'The 1959 Strike', in Peter Hempenstall and Noel Rutherford (eds), Protest and Dissent in the Colonial Pacific (Suva, 1984).

Sanadhya, Totaram Fiji Dvip Men Mere Ikkis Varsh (Delhi, 1915).

Scarr, Deryck Fiji: A Short History (Sydney, 1984).

Scarr, Deryck Ratu Sukuna: soldier, statesman, man of two worlds (London, 1980).

Shepherd, C.Y. The Sugar Industry of Fiji (London, 1945).

Spate, O.H.K. The Fijian People: Economic Problems and Prospects (Suva, 1959).

Tinker, Hugh Separate and Unequal: India and the Indian in the British Commonwealth, 1920-1950 (St Lucia, 1976).

Walters, R.F. Koro: Economic Development and Social Change in Fiji (Oxford, 1969).

Woodruff, Philip The Men who Ruled India (New York, 1954). 



\section{Appendix: Telling the Life of A.D. Patel}

Ambalal Dahyabhai Patel, or 'A.D.', as he was universally known, was the greatest leader of the Indo-Fijian community in colonial Fiji and, arguably, one of the country's most brilliant public intellectuals. Steeped in the Gandhian tradition of politics, at whose dawn he came of age, possessing astute political skills, widely read and far-sighted, at home in several languages, the most outstanding criminal lawyer of his day, he strode the public stage like none other. Often at the centre of the most momentous events in Fiji's post-war history, he was nevertheless unable, in his own lifetime, to realise the vision of a non-racial political culture based on the principle of the common roll. Born in Gujarat in 1905, Patel came to Fiji in 1928 and died there in 1969, a year before the colony became independent.

The most ardent advocate of Fiji's independence is now a forgotten figure in Fiji, remembered, if remembered at all, in a few primary and secondary schools which bear his name and among the fading generation of National Federation Party supporters, the party he founded in 1963. On the other hand, Patel's counterpart among Fijians, Ratu Sir Lala Sukuna, is honoured in public memorials and a national holiday named after him, his legacy of chiefly leadership commemorated in an authorised biography. ${ }^{1}$ In recent years, Sukuna has become somewhat of a national public icon while the public knowledge of Patel's enormous contribution to the political life of his adopted country, and the inclusive non-racial vision he espoused all his life, has receded, a result, no doubt, of a deliberate policy of manicuring reputations and accentuating things Fijian in the broader scheme of things. However great or worthy a non-Fijian, it is unlikely that he or she will be allowed to compete for national limelight with the stars of the Fijian establishment. ${ }^{2}$ Fiji's icons will always remain Fijian.

In 1997, after a decade of interrupted research, I published my biography of A.D. Patel, A Vision for Change: A.D. Patel and the politics of Fiji. ${ }^{3}$ I reflect here on how I came to write the biography, the sources I used and how these helped or hindered my research effort. Ten years on, new sources of information, principally the Colonial Office records at the Public Record Office (PRO) in Kew Gardens, have became available on the most crucial decade of Fiji's political

1 See Deryck Scarr, Ratu Sukuna: soldier, statesman, man of two worlds (London 1980).

2 An authorised, partly taxpayer-funded biography of Ratu Mara is currently being written and negotiations are under way for a Ratu Mara Chair in Fijian Studies at the University of Fiji.

3 Published in 1997 in the 'History of Development Studies Series' by the National Centre for Development Studies, The Australian National University. 
evolution - the 1960s - in which Patel had a major role to play. ${ }^{4}$ Does the new archival material require revision of the conclusions I reached in the book? Does it fundamentally alter the terms of the debate about Fiji's decolonisation? These and related questions form the substance of this chapter.

I do not quite know when I first heard A.D. Patel's name. There was our neighbour, Mr Ram Dayal Singh, an illiterate but wealthy cane farmer and bus-owner, whom we grew up calling Patel. He was nicknamed after A.D., apparently for his ingenious, irrefutable arguments in village meetings to sway decisions in his favour, as A.D. Patel, the canny criminal lawyer, did in the court room. But this connection came to me much later. I must have heard Patel's name during the 1959 strike, prolonged and devastating, causing a shortage of sugar at home and often making us go without it. Patel was the leader of the strike. His name, mentioned in disapproving tones on the radio which had just arrived in our settlement, was at the outer edges of our political consciousness during the 1960s as Fiji hurtled towards independence. Labasa was a rural, isolated backwater then, and politics was never discussed at school except perfunctorily and surreptitiously among teachers and then, too, away from the earshot of students.

It was at university that I first became aware of Patel's role in Fiji's public life. I soon discovered that most official records and recollections, oral and written, either deified or demonised him; frequently the latter among the urban elite who sought to shore up not shake the colonial establishment. The Fiji Times, the only local daily then, portrayed Patel always as a dangerous man bent on wreaking havoc on the country to gain political power at any cost. I realised the full range and scope of Patel's contribution after I had finished my postgraduate studies at The Australian National University, published my dissertation, and, getting interested in the more recent history of Fiji, was on the lookout for a new topic. It was then that A.D. Patel's life suggested itself. Existing references to Patel's ambition and his dubious commitment to Fiji simply whetted my appetite. ${ }^{5}$ There was, on reflection, another reason for my interest in the man. Soon after returning to Fiji, I began to take scholarly interest in contemporary national politics. ${ }^{6}$ The National Federation Party was tearing itself apart over leadership in the 1970s. As I sought to understand why, I got more and more

4 An extensive collection of documents covering the period 1960 to 1970 has been published in Brij V. Lal (ed.), Fiji: British documents on the end of empire, Series B, vol. 10 (London 2006).

5 Thus Deryck Scarr, the historian of the Fijian establishment, in his Sukuna biography, writes disparagingly about Patel's role in the 1943 strike, commenting on his 'new-found patriotism' (Ratu Sukuna, 133). K.L. Gillion, in his The Fiji Indians: challenge to European dominance, 1920-1946 (Canberra 1977), 172, provides an assessment of the strike that repeats almost verbatim the colonial government's view: 'Once again in the history of the Fiji Indians, communalism, factionalism, pettiness and personal political ambition had triumphed over unity and statesmanship'.

6 An early result of this interest was my edited collection Politics in Fiji: studies in contemporary history 
interested in its early history and, as an extension, in the charismatic leadership of its founder. By the 1970s, Patel had become, in the eyes of his supporters, a mythic figure, similar in influence and stature to Ratu Sir Lala Sukuna.

Having resolved to work on Patel, I wrote to his widow, Leela, expressing my wish and seeking her permission to consult Patel's papers (if they existed). The reply never came: people in Fiji do not generally write letters, but permission was generously given when I began the project and approached the family in person. The family cooperated fully, but not once did they ask to see the manuscript when it was completed or seek to know about my lines of enquiry. I was welcomed with open arms and allowed to consult whatever papers I wanted, including Patel's private letters and his diary, his official correspondence. ${ }^{7}$ His children, especially Patel's two daughters, Pratibha and Vasantika, placed at my disposal letters their father wrote, and Leela answered questions about the family scene: the long car rides, the Sunday picnics, the late night games of bridge, the music and singing, the personal quirks of her late husband, his occasional absent-mindedness as he became absorbed in preparing for important court cases, his incessant appetite for reading. In these conversations, Patel came through as a warm, caring father to whom the happiness of his family was paramount. But the timing was wrong. Soon after writing to Leela, I left Suva for Honolulu where I turned my attention to other topics, the coups of 1987 and the modern history of Fiji. For a while Patel faded from my research radar. A heavy teaching load took its own toll on my time and energy. But upon returning to Australia in 1990, and with books on the coup and 20th century history of Fiji written, I returned to Patel, now with purpose and determination to finish a project I had first contemplated a decade ago. ${ }^{8}$

In Canberra, I was fortunate to have two major sources which were to prove highly relevant to my research. One was the Colonial Sugar Refining (CSR) Company archives at the Noel Butlin Archives of Business and Labour. Patel had been at the centre stage of the sugar industry disputes in 1943 and 1960, and the key advocate for the cane growers before the Denning Arbitration in 1969. His role in the disputes was the cause of much controversy, some of it continuing to this day. ${ }^{9}$ The CSR papers, I hoped, would enable a deeper probing of a controversial subject, which they did but not to the degree I had expected. They were useful in providing an insight into the CSR view of things and how the company sought to influence people and events to its advantage. But apart

7 Patel's papers have been microfilmed by the Pacific Manuscripts Bureau and will be made available to bona fide scholars, with the permission of the family (for a limited period of time).

8 My book on the 1987 coup was Power and Prejudice: the making of the Fiji crisis (Wellington 1988, 1990), and my broader history was Broken Waves: a history of the Fiji Islands in the 20th century (Honolulu 1992). 9 See, for instance, the National Farmers Union publication Children of the Indus, 1879-2004: a history of Indians in Fiji portraying the struggles of an immigrant community for justice, equality and acceptance (Suva 2004). 
from the strike papers, I did not find much of direct value to me. The bulk of the archival material deals with the day-to-day operations of the company, correspondence between various mills in Fiji and the CSR headquarters in Sydney. Like the Patel family, the CSR, too, gave me unconditional access to its papers and placed no restriction on what I might or might not see. Clearly, as far as the company was concerned, its days in Fiji were a part of a receding history. It could be magnanimous because for it, the past was truly past.

The other major source in Canberra was the complete set of the weekly journal Pacific Review which Patel started in 1949. In its early years, the Review was remarkably liberal and informative, bringing to Fiji news from around the world that was critical of imperial and colonial practices, news which the Fiji Times would never publish. The weekly died with Patel. Past employees and correspondents of the Pacific Review had told me that in the 1950s, when Patel was out of active politics and to a lesser extent in the 1960s, when he was the centre of it, he wrote most of the editorials. The Pacific Review proved indispensable for my research, providing me access to material, sometimes confidential, that I could not find in the archives. Pacific Review's Hindi counterpart, Jagriti, was less informative but important in gauging the pulse of the Indo-Fijian farming community. Both these newspapers were effective counterweights to the Fiji Times and the Fiji Broadcasting Commission. In 1989 and 1990, I wrote to several former colonial officials who knew Patel and worked closely with him, especially when he was Member of Social Services between 1964 and 1967. I also wrote to former governor Sir Kenneth Maddocks and Lord Denning, whose responses are discussed later on. ${ }^{10}$

By the time I went to Fiji in 1992, I had gathered much material of direct relevance to the project. In Fiji, I was keen to pursue three sources. The first was archival. Much of the material before 1947 I had already seen when researching my BrokenWaves. Unfortunately for the 1960s, the critical period in Fiji's transition to independence, the files were not available under the thirty-year rule. They were available now, but were not of much value. The substance of the most important policy papers was already available in the newspapers or in private collections. I was told by a very senior colonial official about five years ago that much of the sensitive, personal material about prominent leaders had actually been destroyed just before independence, apparently a fairly standard practice at the close of colonial rule. Besides unpublished files, I systematically read all the Hansard for the years Patel was a member of the Legislative Council (1944-1950 and 1963-1969) to gauge his views on controversial public issues of the day. The second mission I had to accomplish in Fiji was to consult Patel's private papers, and the third was to interview people who knew Patel or were in some way associated with him.

10 These letters are in my papers which will be donated to the Pacific Manuscript Bureau in due course. 
By 1994, I began writing the book, and by 1995 had managed to produce a substantial draft. But I was then called to serve on the Fiji Constitution Commission from 1995-1996. The disruption was prolonged and intense. Nevertheless, I used whatever free time I had to write and revise chapters. In one important sense, the timing was fortuitous. Writing and reflecting on Patel's life, often deep into the night, kept the forgotten struggle for a just and fair constitution for Fiji and all its people at the forefront of my mind. I was acutely aware of the missteps and failures of past efforts and keen to move beyond Fiji's constitutional cul-de-sac. An awareness of the past weighed heavily on my mind during these two critical years when we ourselves were charting a new course for Fiji. I had written in my Broken Waves that Fiji's modern history was a history of missed opportunities, and I hoped very much that our work would not take that route.

I will not revisit the central arguments of the biography here. The reception has been warm, both in published reviews as well as in private correspondence. I particularly cherish a private, unsolicited, letter from Peter France, sometime Secretary for Fijian Affairs and the author of the great Charter of the Land: custom and colonisation in Fiji. He wrote on 19 March 1998: '[Y]our book made me feel at the same time a regret that I had not got to know A.D. better and a satisfaction that I had been able to live, for a time, inside his head. You demonstrate superbly that A.D. often spoke and acted, from a position not only of intellectual, but of moral superiority. This was emphatically not widely recognised during his lifetime and we are all in your debt for pointing it out'. But privately, some individuals, usually former politicians bitterly opposed to Patel but who had now joined the National Federation Party after leaving the Alliance Party for a variety of reasons, wrote to me to say that I had grossly exaggerated Patel's role, elevated him to the level of statesman when he was nothing more than a common garden variety politician, a grasping Gujarati feeding off the ignorance of cane growers whose case he claimed to champion. But negative responses were few. Some pointed out, gleefully or helpfully, minor errors which will be corrected in any future edition.

This leads me to the value of private correspondence for my research. Most of these were from British colonial officials who had served in Fiji on lengthy tours of duty, most of them in departments directly dealing with the Fijians. They elucidated points, clarified doubts and suggested other contacts or lines of enquiry. Their value is immeasurable, not least because they provided a counterweight to the Patel papers. I shall illustrate this with a small sample of responses I received. The first is from Sir Kenneth Maddocks, governor of Fiji between 1958 and 1964, a critical time for the colony, coinciding with the industrial disturbance in Suva in 1959 and a strike in the sugar industry in 1960 and the first official move, after nearly thirty years, towards constitutional change 
preparing the way for greater internal self-government. Patel was pilloried in the press and by his critics for his vaulting ambition, his heartless attitude to the suffering of the cane growers he was representing. The Fiji Times wrote about Patel and his followers as 'cowards who hide in cane fields to destroy by fire the fruits of other men's labour...self-seeking, politically ambitious, emotionally twisted grabbers of power by lies and intimidation'. ${ }^{11}$

Maddocks, who had come to Fiji from Tanganyika where he had been governor, saw Patel as a 'very capable, quick-witted and experienced advocate, determined to press his case forcefully and inflexibly'. The strike had antagonised some Fijian cane growers, caused violence and necessitated the declaration of emergency in the sugar belts of Fiji to protect farmers who wanted to harvest or, in effect, break the strike. All that was on the debit side. 'On the other hand', Maddocks continued, 'there is no doubt that he had a case'. But this is not what the governor said at the time or in his correspondence with London. Throughout the sixties, everyone denied that Patel had a case. For its part, the CSR viewed cane growers as a lazy, profligate lot whose sorry fate was entirely their own doing.

The strike was broken, and a commission of enquiry under Sir Malcolm Trustram Eve instituted. The Eve report criticised Patel as an intelligent but misguided man who could, if he wanted to, provide leadership of the 'right kind'. Eve accused Patel and his colleagues of causing disruption in the sugar industry 'in the hope of gaining advantages for themselves and of trying to drive the millers out of Fiji'. The sugar industry had become a vehicle for 'ambitious politicians' ${ }^{12}$ Ambitious politicians: these are almost exactly the same words used to describe the strike leaders in 1943. Privately, Eve respected Patel's integrity, according to Robert Sanders, a senior colonial civil servant who served as Secretary to Cabinet for many years after Fiji became independent and who ghosted Ratu Mara's memoirs. Whatever the differences between himself and Patel, Eve said to Sanders, 'one loyalty he was convinced Mr Patel had was his loyalty to his Inn [Middle Temple]' and 'whatever other misgivings he might have he could rely on this'. Patel's opponents seized on Eve's public condemnation in his report to excoriate him. But in truth, as Patel had divined, the contract based on the Eve report broke many farmers and sent them into bankruptcy. Vijay R. Singh, who had led the anti-Patel faction during the strike, later called Patel the greatest leader the growers had ever had, as did N. S. Chalmers of the rival cane growers' group. Interestingly, when Patel went to London for the 1965 conference, Eve, by then Lord Silsoe, invited Patel for tea at his house, the man he had condemned four years back.

\footnotetext{
11 Fiji Times, 22 Aug. 1960. On 26 August, the newspaper wrote about political demagogues 'who would scramble, scuffle and skirmish for power as soon as the Colony came within the sight of substantial measure of self-government'.

12 See Sir Malcolm Trustram Eve, Report of the Fiji Sugar Inquiry Commission (Suva 1961).
} 
After a decade of grief in the sugar cane growing community, when the Eve contract expired, Lord Denning, Master of the Rolls in the United Kingdom and a highly respected judge in the Commonwealth, was appointed to arbitrate a new contract. ${ }^{13}$ The atmosphere was charged. In 1969, Fiji was just a year away from independence. The war was on for the vote for the Indo-Fijian community in the cane belts of Viti Levu and Vanua Levu. Ratu Mara, keen to bolster his image as a multiracial leader, and encouraged by the members of the Indian Alliance and the Alliance-oriented Kisan Sangh, courted the Indo-Fijian vote assiduously. At the arbitration, the Alliance was represented by the lead counsel Geoffrey Brennan QC, later the Chief Justice of Australia. The Federation of Cane Growers, affiliated to the NFP, was represented by A.D. Patel (and Karam Ramrakha and Siddiq Koya). In his report, Denning confirmed what Patel and others had been saying throughout the sixties about the Eve contract, that it was heavily biased towards the millers and prejudiced against the growers. '[U]nder the Eve formula,' Denning wrote, 'the risk of loss is all on the growers. None at all on the millers: or, at any rate, none to speak of'. Denning regretted Patel's death during the course of the arbitration and praised his advocacy skills: 'He was an accomplished advocate who presented admirably to me the case of the Federation'. But the Alliance went out of its way to claim that Denning's progrower report was the result of its own representation before the arbitration. ${ }^{14}$ It was a popular claim, effective in the 1972 election campaign when the Alliance managed for the first - and the last - time nearly to win a quarter of the IndoFijian votes.

What was the truth? Did Patel's advocacy have any effect at all on the outcome of the arbitration? To find out, I wrote to Lord Denning himself, not really expecting a reply, not knowing whether the good Lord was still alive and active. To my great delight, I received a handwritten letter on House of Lord's stationery on 20 January 1990. 'I remember A.D. Patel well', Denning began. 'Of all the lawyers who appeared before me, A.D. Patel was outstanding. He even out-shone Mr Brennan (now of the High Court of Australia). He was a master of all the facts and particularly of the sugar industry in Fiji. He presented them with skill and understanding. It was his persuasive advocacy that led me to my report which was in favour of the growers and against the millers.' And what about Patel the man himself? 'A.D. Patel was intellectually the most brilliant, as a character the most honourable, and as an advocate, the most persuasive. Quick in mind, fluent in speech, he stood out above all.' But this fact came to light only in 1990, twenty years after Patel's opponents pilloried the man and downplayed his enormous contribution to the sugar industry in Fiji. Denning's priceless letter sets the record straight once and for all on a matter of great political moment in Indo-Fijian history: the beginning of the end of the CSR in

13 See The Award of the Rt. Hon. Lord Denning in the Fiji Sugar Cane Contract Dispute 1969 (Suva 1970).

14 See, for instance, 'The Sugar Contract Scorecard', The Fiji Nation, October 1969. 
Fiji. The value of such private correspondence cannot be overemphasised, nor the importance of luck. Parts of Denning's letter have been quoted in speeches in Fiji, but to no observable effect as far as I can tell.

Between 1964 and 1967, Patel was the Member for Social Services in the colonial government. Ratu Mara was the Member for Natural Resources and John Falvey the Member for Communication. The Membership System was an intermediate step toward full internal self-government later. About this period in Fiji's history, no outsider was a closer observer of events than Leonard Usher, then editor of the Fiji Times. Usher was an unapologetically, energetically, pro-establishment journalist whose assumed air of objectivity was insufficient camouflage for an intense dislike of Patel and his brand of politics. Acting Governor P.D. Macdonald wrote to London on 6 August 1965, criticising Usher who 'slyly hints at the unreasonableness of the attitude of the Federation group, and the rightness of the stand taken by the other groups; he stresses the difficulties and deadlocks at the conference, hinting that these are all the fault of the Federation group rather than encouraging the hope that statesmanship and compromise will prevail' ${ }^{15}$ The Fiji Intelligence Report for December 1965 reported of Usher having 'developed an almost pathological dislike of the Federation Party, and A.D. Patel in particular'. Trafford Smith, Assistant Under-Secretary of State for the Colonies, had a different opinion. 'A charming man to meet, not the bogeyman the Fiji Times makes him out to be'. ${ }^{16}$ I knew of Usher's political leanings and prejudices. The records in London confirmed them in unambiguous terms. But I do not know if the government, knowing the facts about Usher's mischievous role in fanning the anti-Indian flame, ever cautioned him. Probably not, for the propaganda continued unabated.

The pages of the Fiji Times in the 1960s were full of anti-Federation invective. In an interview early in 1990, I asked Usher of his views on A.D. Patel. He praised Patel's intelligence and learning, his mastery of the English language, his rhetorical flourish (as virtually everyone I spoke did), but thought he was stubborn, uncompromising, politically ambitious for himself and his community and dangerous for Fiji. As Member of Social Services, Patel was a disaster, Usher said, because he did not take his responsibilities seriously, coming in late to the office, cursory with his administrative duties. The pattern was predictable. In Usher's mind, Patel was intent on wrecking the Membership System if only to vindicate the view that complete independence was the only answer to Fiji's problems. I asked Gordon Roger about this. Roger, a New Zealander like Usher, was a long-time Director of Education in Fiji, who had served directly under

15 Acting Governor to Secretary of State for the Colonies, 6 August 1965 in CO 1036/1216, E83.

16 CO 1036/1551, no. 1, March 1965. The publisher of the Fiji Times was no less anti-Indian. Writing in the Pacific Islands Monthly in February 1952, he said 'I have little liking for the Indians. In the main, they are arrogant and disloyal and are dishonest in so far as their evasion of taxation is concerned'. 
Patel in the mid-1960s. Roger had a completely different story to tell. According to him, Patel was an ideal mentor for senior civil servants. He differed from his successors in two main ways, Roger said. First, 'he had (or at least he gave the impression of having) no axe to grind. This meant he was able to look at educational ideas and problems in terms of education, not in terms of votes; and because we (his senior staff in the Edn Dept) had been brought up to do likewise there was in fact very little friction between us'. He goes on: 'I doubt whether we really appreciated at the time just what an easy introduction to the future ministerial system A.D. was in fact giving us'. There were differences between Patel and his staff in setting priorities, but Roger says that 'once we started looking at things through his eyes - he was a very persuasive teacher! - our generally negative attitude became much more positive'.

Roger gives an example of the way in which Patel 'handled' his staff. When he and his deputy Max Bay opposed an idea Patel had put up, he summoned the two to a morning tea-time meeting to explain their opposition to his proposal in person. 'It was the first time he'd used this ploy, and it proved very effective, because a hurriedly-convened staff meeting at $8 \mathrm{am}$ had shown me that the idea wasn't in fact nearly as impracticable as it had sounded 20 minutes earlier. When I subsequently told him how near I'd been to saying 'no' again, he smiled engagingly and said, in the nicest possible way, 'You know, Gordon, it's good for all of us to be made to think sometimes". Kenneth Bain, Patel's Permanent Secretary for Social Services, concurs. 'The circumstances of our coming together in this [the Membership System] were unusual and our relationship became one of considerable interest and, I believe, trust'. This, Bain, goes on to say, 'in spite of the fact that my wife stood for election to he Legislative Council as an Alliance-endorsed candidate'. In the circumstances, one must give preference to Roger's and Bain's version, based as it is on direct experience, over Usher's based on hearsay and prejudiced evidence. The extent of harm to race relations and to political negotiations by Usher's jaundiced views is beyond measure.

A constant refrain throughout the 1960s was that Patel was anti-European, which Patel denounced as a 'wicked lie'. How could he be anti-European when his first wife was an English woman? When his young children were attending school in England? 'If A.D. was anti-European', Roger recalled, 'I do not recall his ever showing it in my presence. Personally, I doubt whether he was. But even if he were, why not? There were plenty of Europeans around at the time who made no secret of the fact that they were anti-Indian'. Ray Baker, District Officer in the Fiji in the 1960s, did not think European colonial officials were overtly or deliberately anti-Indian, but it was 'probably true to say that most expatriate administrators were at that time pro-Fijian in the sense that we felt in sympathy with their perception of themselves as the taukei - the owners of most of the land but economically backward and overtaken in population by 
immigrant races'. On this aspect none other than Governor Derek Jakeway was in complete agreement. He said on a visit to Australia in February 1965, just as preparations were under way for the constitutional conference in London in July, that 'it was inconceivable that Britain would ever permit the Fijian people to be placed politically under the heels of an immigrant community'. Jakeway got it wrong. In truth, the Indo-Fijian leaders did not want any community to be dominated; they wanted political equality, and equality of representation. Patel was not anti-European: he was certainly anti-colonial. In the minds of colonial officials the two were one and the same thing.

Those who relied solely on the reports and coverage in the Fiji Times would, unsurprisingly, form a decidedly unpopular impression of Patel and his followers. But A.C. Reid's private recollection suggests another view. Reid was the trusted Secretary of Fijian Affairs and member of the hugely influential Fijian Affairs Board. In 1949, Patel, then a member of the Executive Council, visited Labasa with Swami Rudrananda. Reid then was Commissioner Northern. The official team was invited to the opening of a new school at Tuatua, on the outskirts of the local township. As Reid was walking up from the main road with Patel and Swamiji, they 'were suddenly confronted by one of the guests - annoyed at the flying of the Sangam flag over the gathering. As I remember, the management was Sangam but the school would be expected, under the rules, to fly the Union Jack on official occasions. There was an embarrassing pause until, bearing in mind A.D.'s senior position in the government, I sought his assistance and he turned to the Swami. While I did not know the precise content of what was said, it was clear that A.D. was determined to adhere to the rules, notwithstanding the Swami's glum reaction. I may add that a very new-looking Union flag was brought out of the school and hoisted up the flagpole'. Patel was, first and foremost, a constitutionalist in the rather old-fashioned way, acutely aware of the need to respect certain protocols and conventions.

Private recollections of the type I have quoted above, mostly from people who, at the time, were on the opposite side to Patel, help to complicate a picture of a man reviled in his time. My conversations with people in Fiji provided further insights into how Patel approached politics. He was a born politician who kept his finger squarely on the pulse of the community, finding time to talk to ordinary people about their problems and concerns. Every Saturday, without exception, he would go to the Nadi market to do the family's vegetable shopping - less to buy things than to mingle with the people. Whenever he returned from Suva to his home in Nadi, he would stop his car and buy fruits and vegetables Fijians sold by the roadside. When his wife protested at his extravagance, he would say, 'When that boy returns to his village, he will tell his family and friends that he sold vegetables to Patela. That is free publicity for us'. Whenever Patel addressed rallies, especially in western Viti Levu, he 
would ask the local chairman of the party what was being said on the ground so that he could adjust his speech accordingly. In 1963, Siddiq Koya, a Muslim, stood for election in a predominantly Hindu constituency. His opponent was James Shankar Singh, from a large and powerful Arya Samaj clan in Ba. His supporters, so it was reported, were telling people to vote for Singh and not Koya. When Patel was told this, he began his speech by saying 'It is true that Mr Koya is a Musalman, but at least he has remained true to his faith'. He did not need to mention 'James' Shankar Singh's name to drive home the point about Singh's conversion to Christianity. Religion never again surfaced in the campaign. Stories like this abound in the fading memories of a passing older generation.

When I wrote the biography, I had seen all the records, both open and confidential, under the thirty-year rule at the National Archives of Fiji. But I had not seen the enormous archives at the Public Record Office. These contain dispatches from the governor in Fiji, records of deliberations in Whitehall about the future directions of policy regarding Fiji's independence, conference proceedings, and petitions and letters from Fiji. Would I have written a different book if I had seen the London records? At first, I was naturally nervous as any researcher would be, writing a book without consulting a major repository! What if I got the story all wrong? We historians pride ourselves on doing as exhaustive research as possible before putting pen to paper. We all aspire to some sort of definitiveness, a longer shelf life even though we know how utterly impossible that goal can be. So I was nervous.

But now, having seen all the London records, I honestly do not believe that I would substantially change anything I have written substantially: revisions at the margins, yes, major amendments, no. To be sure, it would have been good to have seen the records before I wrote the biography, if only because they would have deepened and reinforced many of the conclusions I reached. All important policy discussions found their way into print in one form or another, although not always the thinking which led to a particular policy recommendation. I will give just a few examples to illustrate the point. It was common knowledge, as Jakeway and Baker confirmed, that official sympathy lay with the Fijians, and that the United Kingdom government would pay close attention to Fijian aspirations and concerns when formulating policy. Nor was there much sympathy for Patel's advocacy of common roll. Fijians and Europeans were opposed and so too was London. That was common knowledge; the London records show just how pervasive that sentiment was.

The extent of London's concern was stated by Julian Amery, the parliamentary Under Secretary of State for the Colonies, who visited Fiji in 1960 during the sugar cane strike. Upon returning to London, he penned a memorandum whose central concerns echoed in all the major correspondence and political negotiations 
between Suva and London throughout the 1960s. Amery was a well connected, supremely self-confident and given to expressing sharp, unequivocal opinion. ${ }^{17}$ 'The Fijians and Indians are more distinct as communities than Jews and Arabs in Palestine, Greeks and Turks in Cyprus or even Europeans and Bantu in South and Central Africa.' Fijians deeply feared Indian domination, he said, and their confidence in the government had been shaken by reports (Burns and Spate) calling for fundamental overhauling of Fijian institutions and opening up the traditional society to greater individual freedom. He reminded London that it was the Fijians who had been the loyal community, a reference to enthusiastic Fijian participation in the Second World War and in the Malaya campaign in the 1950s. The Fijians provided 75 percent of the colony's armed forces. 'The islands could hardly be governed without them, let alone against them.' In the circumstances, Amery advised London, it was 'impracticable to think if terms of a single Fijian nation of a common roll.'

Amery's views were widely discussed in the Colonial Office. Many accepted that his prognosis was probably correct though his rhetoric heated. Nonetheless, everyone agreed to respect the Fijian position. Even when Fijians were contemplating some minor concession to common roll, London was not keen to nudge them along. As Jakeway put it, 'some gentle selling of the attractions of a limited common roll element in the next constitutional stage has been done with all three (Ratu George Cakobau, Ratu Penaia Ganilau and Ratu Mara) and does not appear to have fallen on entirely unreceptive ground'. In the 1965 conference, London actively sought to engineer an outcome that would put Fijians in control, within the overarching ambit of Westminster-style parliamentary democracy. The conference failed to reach consensus, and the Colonial Office was quick to blame Patel and other members of the Federation Party for the debacle. They started the conference on the 'wrong foot' and spectacularly mishandled their case, as Trafford Smith put it in a confidential letter to Jakeway.

A close and careful reading of the Colonial Office records in fact leads to another conclusion, one which becomes all too obvious when London's thinking is borne in mind. London was concerned to appease the Fijians, and Eireen White, the parliamentary under-secretary and chair of the conference, held private talks with both Ratu Mara and John Falvey, but not with the Indian delegation, to impress upon them the need to meet others halfway. This contradicted the Colonial Office advice that White hold private discussions with all the three parties separately to gauge the extent of compromise each was prepared to make. Trafford Smith was especially critical of the Federation group bringing up the matter of common roll late in the conference proceedings. But the Colonial Office itself had recommended the avoidance of the issue at an early stage to prevent the 'striking of attitudes' which could conceivably lead to a deadlock.

17 His father Leopold Amery was Secretary of State for India in the 1940s. 
To argue later that the Federation group should have declared their hand earlier directly contradicts the Colonial Office advice. Patel told his audiences in Fiji that the London conference was merely a 'rubber stamp' for a constitution already decided by Her Majesty's Government. ${ }^{18}$ He was condemned for saying this, but as the records show, he had spoken the truth. He was also right that London's mind was focused elsewhere - on Aden - when the conference took place.

The London records show clearly how personal chemistry between the principal participants played a role in the way events unfolded. Sir Derek Jakeway, coming from Sarawak as its chief secretary, had developed empathy for the Fijian people, had seen them in action against Chinese communist insurgents in Malaya, and in Fiji he was active behind the scenes trying to get the Fijians and Europeans to organise politically. ${ }^{19}$ The Alliance Party was in fact his brainchild. The Federation Party attacked Jakeway's partisan statements and even petitioned the Colonial Office for his recall. London denied any impropriety in the governor's behaviour, but once again, suspicions about the governor's bias were well founded.

Fijian leaders were chosen to attend specialised courses in London, and many of them formed close friendships with officials in London. Officials from the Colonial Office were assigned to the visitors, sometimes to help them find accommodation and schools for the children, or take them on tours of London. The closeness was reflected in private letters. During the course of an interview with a visiting official from the Colonial Office, an Indian journalist, Krishnamurthy, collapsed and died. In a handwritten letter, Ratu Mara asked Harold Hall, Assistant Secretary and Head of Pacific and Indian Ocean Department at the Colonial Office, to send more such officials. Humour in extremely bad taste, you might say, but this was not uncommon. ${ }^{20}$ Richard Kearsley, a member of the Alliance Party, felt socially close enough to the UK officials at the 1965 conference at Marlborough House to call Patel a 'rat'. John Falvey chimed in 'Of course we all hate the Indians'. The English had a patronising, romantic, affinity for Fijians and things Fijian, ${ }^{21}$ but coolness and distance, perhaps even suspicion and muted hostility, characterised their attitude to the Indo-Fijians, especially their

\footnotetext{
18 CO 1036/1216/E91, Fiji Intelligence Report, 12 December 1965.

19 Jakeway told Nigel Fisher on 17 Jan. 1966 that 'Behind the scenes I have encouraged the Alliance leaders to look for professional advice on party organisation and running an election campaign, and it was I who gave Falvey the name of Sir William Urton well as those of his counterparts in the other occupants of South Square, the Labour and Liberal Offices. This was done with the knowledge and agreement of Trafford Smith, and also Mrs White'. CO 1036/1586, Jakeway to Nigel Fisher, 17 Jan. 1966.

20 Sir Vijay R. Singh told me at a dinner with Praveen Chandra Vijendra Kumar in Brisbane in late 2005 another Mara story. As Patel's funeral pyre was alight and as the plane taking Mara and Singh back to Suva flew over the crematorium, Mara called Singh to his side and said, pointing to the fire, 'Look Vijay, give people what they want and they will flock to you'.

21 The feeling continued. A. Crosbie Walsh, who taught at the University of the South Pacific in the late 1970s, wrote that 'I had a dislike of Indians (a not uncommon attitude held by Europeans seeking to protect
} 
leaders and especially Patel. Many in London and Suva - from Trafford Smith to Sir Robert Foster - expressed open respect for Patel's intellect and integrity, but personal rapport was absent. No Indo-Fijian politician enjoyed the closeness with European officials that Fijians did.

It did not help matters that in one encounter with Jakeway, Patel humiliated the governor and forced him to back down. Sketchy details are available in the Fiji newspapers, but the full extent of the damage was revealed in the PRO papers. As preparations for the 1965 conference intensified in Fiji, garbled versions of private discussions began to appear in the media and on the Fiji Broadcasting Commission (FBC). The latter came under Patel's portfolio as Member for Social Services. In one meeting, Patel said that, having studied at the London School of Economics, he could call himself an 'economist' and he was an 'optimist' about Fiji's future. The Public Relations Office reported that Patel had called himself a 'communist' and an 'opportunist'! The FBC called Federation leaders 'badmash', hooligans. When Patel attacked the Commission for its anti-Federation bias, Jakeway rebuked him and forthrightly asked for his resignation if he could not observe the rules of collective responsibility governing the Membership System. Anything other than a public dissociation from these attacks on the Public Relations Office must bring into question your continued membership of the Executive Council.' Jakeway was determined to get the better of Patel, determined to discipline him once and for all.

Patel replied that he could not be expected to 'defend wrongful acts of civil servants or defend them against public criticism' when he himself, as Member for Social Services, 'had no power to hold officers in his portfolio to account'. He pointedly reminded the governor of the terms and conditions upon which he had accepted his appointment, saying that his present action did not breach them. He had joined the government, he said, 'to serve my people - not to forsake them: and I am not prepared to sell my soul for a mess of pottage'. He offered to resign if that was what the Secretary of State wanted. Jakeway had asked the Colonial Office to take a hard line against Patel. Trafford Smith sympathised with Jakeway, but warned him of the 'serious and far reaching' consequences of not having Patel, the dominant leader of the Indo-Fijian community, in the Executive Council. Expelling Patel would do the government more harm than good. And, after all, Patel did have a case. There was nothing that Jakeway could do but to bite his tongue, accept this advice, retract his ultimatum, and keep Patel in government. London hoped that the 'whole incident has not so seriously undermined the confidence of the other communities in the Indians as to make progress between now and the conference impossible.$^{22}$ It had, and

Pacific indigenes from every race except their own) and I did not want to be like this'. See his 'A scatter of islands: reminiscences from Tonga, Rarotonga, Niue, and Fiji,' in Eric Waddell and Patrick Nunn (eds), The Margin Fades: geographical itineraries in a world of islands (Suva 1993), 106. 
Jakeway had to share a part of the blame for the fiasco. I had an inkling of all this when I was going through the Patel papers and reading the Pacific Review: the London records provided the details and clarified the picture.

The 1965 conference was a triumph for the Fijian and European delegation and utter defeat for the Indo-Fijians. Soon after returning from London, some within the Federation Party began questioning whether its constitutionalist stance was appropriate to extract concessions from the British. I was told of a rift between Siddiq Koya and A.D. Patel, indeed a private, potentially partysplitting confrontation in $\mathrm{Ba}$, when Koya threatened to leave the party. Several people confirmed the episode but none knew precisely the cause of the rift between the two men. I mention the episode in the book, but do not, could not, elaborate. The monthly 'Fiji Intelligence Reports' provide one plausible clue. Koya was 'restless with Patel's autocratic control of the party machine and his apparently passive attitude to the outcome of the London conference'.${ }^{23} \mathrm{He}$ told his colleagues that Patel's approach had failed and that he wanted to form a 'Subhash Party'. This was after Subhash Chandra Bose, the leader of the Indian National Army, who wanted to eject the British from India by force.

Apisai Tora, whom Koya had defended against the charge of arson in the longest running criminal case in Fiji history (burning down the Korolevu Hotel near Sigatoka) and who had converted to Islam (assuming the name of Mohammed), reportedly told someone that he was twice offered two thousand pounds by Koya on behalf of the Federation Party if he would pledge his support for 'certain courses of action'.$^{24}$ What course of action, the police were unable to ascertain, but 'physical persuasion' was mentioned to embarrass the government and to force a commission of enquiry into the workings of the Native Land Trust Board. I am not convinced that the Federation Party sanctioned the approach. In fact, I doubt it. Patel, Gandhian at heart, the strict constitutionalist, the follower of protocol and procedure, the loyal member of the Middle Temple, would never countenance such a course of action.

The London records, as mentioned before, clarify and amplify, confirm tentative conclusions and deepen understanding of official thinking. But they do not, I think, substantially alter the picture I sought to draw in the book. On many points, they simply confirm my line of enquiry. An important reason for this is that on most matters of importance, Patel published his letters and messages. He recalled conversations with both the governor and officials from the Colonial Office in public, and these found their way into print, especially in the pages of the Pacific Review, which Patel founded in 1949 and whose intellectual inspiration he remained throughout. When the 1965 conference broke down,

23 CO 1036/1216, E1/88, Fiji Intelligence Report for September 1965.

24 See CO 1036/1216, E/91 Fiji Intelligence Report for November 1965. 
Patel and his colleagues, 'out of respect' for the Secretary of State for the Colonies, accepted the new constitution under protest, but not before writing a lengthy letter to him outlining their reasons for dismay at the final outcome, and promising to 'oppose these proposals by peaceful and constitutional means'. The letter was published in the Pacific Review. So, too, was Greenwood's reply.

This exchange would not have been available to me under the thirty-year rule even if I had travelled to London to consult the records. The newspaper is full of such disclosures. Patel's case for the common roll, his views on the problems in the sugar industry, his fraught relations with Ratu Mara, ${ }^{25}$ his condemnation of colonialism, his speeches in national and international forums (such as at the 1965 conference in London), the substance of letters people wrote to him, all found their way into the pages of the Pacific Review. Besides this journal, the Hansard was also an important source of information. Patel first entered the Legislative Council in 1944 and remained a member until 1950. He re-entered the Council in 1963 and remained its member until his death in 1969. The words, in cold print now, do not convey the passion and precision with which they were spoken, but they display a mastery of the language and eloquent thoughts on a range of issues of urgent importance to the country.

I was particularly lucky that Patel left behind a rich collection of private papers. Some had been destroyed in the 1972 hurricane, but many survived. Patel was decidedly old-fashioned in preserving his correspondence. He kept personal letters (the oldest being his letter to Swami Avinashananda in 1939), letters others sent him, drafts of speeches, ${ }^{26}$ confidential memoranda he received both as the Member of Social Services and as the Leader of the Opposition, newspaper clippings containing his addresses. Patel's large library contained well-thumbed books on many subjects, but there was a predilection towards philosophy and religion. ${ }^{27}$ Patel was a Vaishnavite, a follower of Swami Vivekananda and vice president of the Ramakrishna Mission in Fiji. Together with Swami Rudrananda, his life-long spiritual confidante, he held regular discourses on the Bhagvada Gita at the Mission ashram (lodge) in Nadi. His political speeches were full of references to Indian philosophical texts. Perusing his papers and his library,

\footnotetext{
25 Mara recalled Patel as a 'brilliant lawyer, an eloquent speaker, a charismatic leader of his party, and a doughty opponent. But it has to be admitted that political negotiation with him had proved difficult, and on occasion impossible. In particular he was irrevocably committed to the policy of common roll as a first step, not as an aim for the future, which we were prepared to concede. Therefore, sad as his death was, and a great loss to the Indian community, it did seem to open up for our negotiations a spirit of compromise that might have been hard to achieve otherwise'. See his The Pacific Way: a memoir (Honolulu 1997), 97.

26 People often told me how Patel could speak for hours scarcely glancing at his notes. The truth was that he carefully composed his speeches, wrote them down and then committed them to memory. Patel had astounding powers of recall.

27 Among the many philosophy books in the Patel library are several by Nicolas Berdyaev such as Slavery and Freedom and The Destiny of Man.
} 
I came away with the firm impression that two of Patel's greatest attributes were his brilliant intellect and his deep faith which sustained him in the many political failures and obstacles he encountered in his career.

The personal letters to his children were the most useful and revealing about the man. Much to his wife's distress, Patel never phoned his children whom he had sent to England for private education. Not that he could not afford it: he was a wealthy lawyer and owner of large freehold properties. But, like the English gentlemen of leisure in the late- $19^{\text {th }}$ and early- $20^{\text {th }}$ centuries, he preferred to communicate with his children through letters. In these letters he advised his children about their course of study, about the need to keep company of good people, meaning those who were determined to make something of themselves. But he also discussed political developments in Fiji. In one letter to his eldest son, Atul, he talked of Mara being the 'blue-eyed boy of the British', and complained about the obtuseness of Indian officials towards political developments in Fiji. In a 1967 letter from the Ocean Island to his tiny daughter Vasantika, he wrote about the iniquity perpetrated by the British Phosphate Commission on the Banaban people whose Chief Legal Counsel he was before the United Nations Committee on Decolonisation. His mastery of the language and fluency of his writing are impressive.

It is ten years ago almost since I published my biography of A.D. Patel, following a decade of interrupted research. Do I still stand by the words I wrote then? Were there things I simply missed, gaps exposed by evidence and papers which have since become available, such as the records at the Public Record Office at Kew Gardens? Can I say with absolute confidence that the broad picture I painted remains intact? Nothing that I have seen since I wrote the book would cause me to change my mind, except on low level details. What the records, which were not available to me when I wrote my book, do is to deepen the picture and sometimes enter qualifications. I wish I had seen them when I wrote the biography, but, fortunately for me, they confirm rather than derogate from the picture I painted then.

Patel has had his critics, and been subject to carping comments from some scholars. But these often say more about the prejudices and intellectual predilections of these individuals than the man they wrote about. Patel was not perfect, as I showed in my book. He could be-often was-stubborn, uncompromising, and haughty towards opponents he considered unprincipled or opportunistic. ${ }^{28}$ The worst that was said of Patel, his harshest criticism by officials, was that he was a practitioner of Gandhian politics, but no one ever spelt out precisely what was wrong with Gandhian politics. People told me that Patel was a hard landlord, demanding full rent on time and requiring the highest

28 As Sir Vijay R. Singh told me in early 2006 
levels of husbandry of his tenants. That was probably true, but in this Patel was following the example set by others, including the CSR. Many in Fiji will agree that lack of professionalism in agriculture is one of the serious problems facing the sugar cane growers of Fiji.

When all is said and done, what remains beyond doubt is that, thirty-seven years after his death, his vision for Fiji remains as relevant as it was when he was alive. Racial compartmentalisation was no way to build a cohesive multiracial society, Patel had argued all throughout his life. Long before it became fashionable, Patel talked about the nation as an 'imagined community'. Nationalism, for him, he said in 1964, was 'a question of the mind, it [was] not a question of the colour [of skin]'. Patel received bad press during his life time because he questioned the values and assumptions which underpinned the colonial order, although privately and much later after he was gone, his critics conceded ground. 'A.D. was a fine man,' Q.V.L. Weston wrote privately after Patel's death in 1969, 'stubborn, sometimes too much for comfort'. Weston knew: he was Commissioner Western, colonial officialdom's principal representative, in the heart of the fiery cane belt in western Viti Levu. But, he added, 'it was through his stubbornness that he got his way'. He continued: 'Mixed societies such as Fiji contain a lot of inborn prejudices, which get out of tune with the times and take the leader of the quality and convictions of A.D. to shift. When the tale is told by historians, it will be usually accepted that his way was right'. 


\section{Index}

Agent General of Immigration 13

Agent, of Government of India 15-16

Agreement 24 July 138-139

Agricultural Bank 143

Agricultural Landlord and Tenant Bill

174-176

Agricultural Landlord and Tenant

Committee 176

Agricultural Landlord and Tenant

Ordinance 237

agricultural production, Second World

War 84

AJC Patel and Company 36

Akhil Fiji Krishak Maha Sangh See Maha

Sangh

Ali, Ahmed 242

All-Fiji Indian conference 192946

Alliance Party 219, 249

: by-election 1967230,236

: formation of 207

: response to Federation Party

manifesto 235

Amery, Julian 143-144, 161

Amery, LS 41

Andrews, CF 11, 28, 38

Anthony, James 129

Archibald, Fred 204

Arya Samaj 12, 33, 37 See also education,

Indian

: Deo's influence 109

: elections 193749

: elections 1963160

: in 1950s elections 111

: prohibition debate 107

Ashford, JE 168

Attorney General 164, 174, 199

Atul Kumar trophy 106

Avinasananda, Swami 34, 54-55

Bain, Kenneth 165

Balaganapathi, MR 116, 117
Bandranaike, SWRD 27

Bannerji, Surendranath 27

Barker, Ray 186 fn

Barrett, WM 239

basic tax 177

Bayly, JP 133, 137, 139

Beattie, Hamilton 38

Ben, Leela 105

Bennett, JM 145

Besant, Annie 28

Bhajan mandalis 119

Bharat Mata Day 110

Bhindi, PK 230

Bill of Rights 199, 206

: in Federation Party manifesto 234

Blunt, Edward 8

Book Box Scheme 168

Bowden, Herbert 226

boycott of Legislative Council, 192939

Brennan, Sir Gerard ix-x, 242

British Council 168

British India Association 13

British Phosphate Commission 224

Brown, Doug xix

Buksh, MS 108

Buksh, Nabi 40

Buli 47

Bull, PJ 142

Burns Commission 220

Burns, Sir Alan 184

Burton, JW 11, 28

bus industry 162

by-election 1967 229-230, 231

: Fijian response 237

: results 236-237

Cakobau, Ratu Edward xv, 203, 227

: constitutional talks 1969239

: on death penalty 179

: opposition to common roll 96

Cakobau, Ratu George 23

: by-election 1967 237-238

: constitutional conference 1964188

: Wakaya Letter 186

Cakobau, Seru 2 
Campbell, RO 118

Cane Experiments Consultative

Committee 77

cane growers, Fijian 136

capital punishment See death penalty

Cargill, William 2

Cassidy, Joe 245

caste, girmitiyas 9-10, 11

censorship, Second World War 81

Central Indian Organisation of Fiji 109

Central Indian War Committee 82

cession 2-3

Chagla, MC 27

Chalmers, NS 139

Chand, Ganesh xix

Chandra, Ami 108

Chandra, Ram 46

Charotar 18-19

: and Gandhi's campaigns 21

: Patidars in 20

Chaudhry, Mahendra 118

Chinese 200

Chinese Association 207

Citizens Federation 158-159, 187 See also Federation Party

civil service 92-93

collective responsibility: Executive

Council 165, 176-177

Colonial Office 42, 60, 62, 92

: constitutional changes 163

: constitutional debate 1967229

: Eve Commission 145

: nomination compromise 46

: Wakaya Letter 186

Colonial Secretary 164, 199

Colonial Sugar Refining Company x, ix, 14, 28, 58-59. 221, 241 See also sugar industry

: 24 July Agreement 138-140

: agreement 194375

: Federation Committee 1960 133-136, 137

: Kisan Sangh 61-62

: land leasing 47

: Shepherd enquiry 77
: smallholder system 59

: strike 1943 69, 71

: strike 1960 129-132, 136-137

: contract with growers 1960 132-136

: criticism of AD Patel 153-154

: Denning arbitration 242-243

: early days 5

: Eve Commission 145-146, 150, 152

: Fiji subsidiary 152

: government proposal 1 September

141-142

: opposition to Indian recruitment 84

: opposition to trade union legislation

60

: Pacific War 65

colonialism xiii, xvi

Commision of Enquiry 1943 65-66

: AD Patel's critique of 72-73

: report of 72

Commission to Review the Fiji

Constitution $\mathrm{xx}$

Commissioner of Labour 87

Commissioner of Lands 47

common name xvi, 124, 222

common roll xvii, 15, 38-39, 45, 93, 205,

209

: constitutional conference 1964 189-

193

: constitutional conference 1965 200-

201

: European opposition 41

: fears of 96

: Fijian opposition 41, 96, 191-192

: first campaign 39-40, 42

: post-independence 241, 248

Commonwealth of India League 28

Commonwealth Sugar Agreement 131,

148

: in Denning report 244

communal representation 40, 191, 206,

207, 248

: results of 249

constitution 93-94, 96-98, 190-191, 186

constitution 1965 200, 226

: Bill of Rights 199 
: Europeans in 203

: Fijians in 203

constitution 1969 elections 248-249

constitutional changes 185

constitutional conference 1964 187, 190-

191

: delegates 188-189

: Federation Party boycott 193-194

constitutional conference 1965 197-198

: compromise proposal 209

: independent observers 208

: Indian viewpoint 201

: results of 203, 204, 207-208

constitutional debate 1967 228-229

constitutional talks 1969 238-239

contract, cane growers 1960 132-133

contracts, indentured labour See girmit

Cook Islands: independence 163, 185

cooperative mills 147, 151, 153

cooperative movement 218-219

costs of production, sugar 149-150, 152,

243

Council of Ministers 227, 234

coup 1987 xvi, 249

Crewe Commission 6-7, 99, 209

Cross, David 2

cross-voting 200, 204, 206, 207, 248

CSR See Colonial Sugar Refining

Company

curfew 81

Daniels, John 118

Davenport, Sarah xix

Dean, XK Nasir 40

death penalty 179-181

Deed of Cession 3, 6, 7, 15, 21

: in Wakaya Letter 185

: Ragg's motion 1946 101-102

Defence (General) Regulation 1942 67, 68

Denning, Lord ix, xiv, 242, 243-244, 245

Deo, Pandit Vishnu 22, 33, 86, 242

: commission 194366

: Fiji Samachar 120

: Kisan Sangh 63

: Central Indian War Committee 82

: common roll campaign 39, 41
: constitutional amendment 194898

: early relationship with AD Patel

32-33

: elections 193748

: elections 1966218

: language education 107-108

: opposition to nomination system 44

: political influence 109-110

: prohibition debate 107

: rift with AD Patel 106, 108

: support for Muslim separatism 112

Deoki, Andrew Inder Narayan xiv, 204

: and AD Patel 183

: Sugar Advisory Board 233

: Central Indian War Committee 82

: constitutional conference 1964188

: constitutional conference 1965 200-

201

: elections 1966218

: National Provident Fund 169

: nomination to Executive Council 164

: on death penalty 180

: opposition to university 172

Deoki, Rev 40

Department of Labour 86

deportation, of Indians 126

Destitute Allowance and Minimum

Living Wage 93

diversification, crop 150-151

Dixon, GM 152

Doctor, Manilal Maganlal 13-14

Dudley, David 40

Dugdale, John 112

Dutt, Romesh Chander 27

East African Indian National Congress 40 education 170-171

: adult education 119

: in Federation Party manifesto 234

: Indian 12

: language 169

: localisation of 92

: Ramakrishna Mission 116-117

: secondary schools 117

: teachers unions 171

Education Advisory Councils 170 
Education Department 117, 167

elections 192939

elections 1963 158, 160

elections 1966 213-218

electoral commission 199

Emperor Gold Mines 224 See also gold industry

Enele Ma'afu 2

enlistment, Second World War 82-85

European Electors' Association 97

Europeans: and Fijians 2, 3, 230

: constitution 1965 203, 204

: elections 1966216

: opposition to common roll 43, 206

Eve Commission 145-150, 158

: report of 151-153, 225

: results of 154-155

Eve contract 242-243

Eve, Sir Malcolm Trustram 145, 151

: criticism of AD Patel xiv, 146, 152153, 154

Executive Committee 174-175

Executive Council 93

: Indian elected member 108-109

: Indian nominated member 164

: Membership system 163-164, 165

Fair Rents Bill 168

Falvey, John 136, 143, 186, 194

: 24 July Agreement 139

: as Member for Communications and

Works 163-164

: constitutional conference 1965 196-

197

: on death penalty 180

: opposition to common roll 191

farmers See Kisan

Federation Committee See Federation of

Cane Growers Associations

Federation of Cane Growers ix, 242

Federation of Cane Growers Associations

133-137

: contract 1960 134-137, 140-141

: Eve Commission 145

Federation Party xii, 187

: and 1965 constitution 227
: boycott 1967 232-233

: by-election $1967230,233,236$

: constitutional conference 1964188

189, 193-194

: constitutional debate 1967229

: elections 1966 213, 214-215, 216

: manifesto 233-234, 235

: nationalising gold mines 224

: recruitment of Fijians 230

Fiji Broadcasting Commission 178, 193

Fiji Indian Congress 38

Fiji Industrial Workers Congress 168

Fiji Labour Party 249

Fiji Men Arya Samaj se Shastrath 33

Fiji Minority Party 207

Fiji Muslim League 12, 43

Fiji Muslim League: in 1950s elections 107, 111

Fiji National Provident Fund xviii, 168

Fiji Samachar 120, 154, 165

Fiji Teachers Union 171

Fiji Times 120, 121, 193, 195

: eulogy for AD xi

: on strike 1960142

: reports on India 122

Fijian administration 184, 220-222

Fijian Affairs Act 95

Fijian Affairs Board 192, 220, 221

: and school integration 171

: Wakaya Letter 185, 186

Fijian Affairs Ordinance See Fijian Affairs Board

Fijian Association xi, 207, 136, 237

Fijian Chamber of Commerce 222

Fijian Democratic Party 196

Fijian Development Fund 221

Fijian land ownership 184, 185

Fijians 4, 83, 158, 184,

: opposition to common roll 96, 191-

192, 205, 206

: and Europeans 230

: independence 237

: self-government 231

: tenancy 175

: changes in 1960s 185

: in constitution 1965203 
: in Federation Party 230

: support for Britain 205

Fijian Teachers Association 171, 172

Financial Secretary 164, 199

Fiscal Review Committee 177

Fisher, Nigel 185, 209

Fletcher, Sir Murchison 39-40, 46

: interview with Patel on nomination

45

: opposition to common roll 41-42

: opposition to trade union legislation 60

Forbes, Alexander Kinloch 18, 20

foreign capital, elections 1966 217-218

Foster, AJC 142

franchise

: Chinese 200

: Fijian 158

: Indo-Fijians 15, 38

: Rotumans 200

free migrants, 1930s 36

free settlers, Indian 12

Gandhi, Mahatma x, 11, 13, 29

: AD's speech 1969246

: common roll campaign 40-41

: first satyagraha campaign 17, 20-21

: in AD's speeches 113

: Rowlatt Campaign 25-26

Ganilau, Ratu Penaia 195, 220

: constitutional conference 1964188

: on death penalty 179

: Wakaya Letter 186

Ganji, Chunilal 36

Garnham, Florence 11

Garvey, Sir Ronald 23, 106

General Electors Association 207

Geneva Conference on Sugar 231-232

Ghadr movement 36

Gibson, Harold 89, 94

Gillion, KL 118

girmit 7-8, 9, 11

girmitiyas: and Gujaratis 8-11, 22 See also

indentured labour

gold industry 223-224
Goldfinch, Sir Philip 43, 62, 64

: on land leasing 47

Gopalan, CM 82, 109, 112

Gordon, Sir Arthur Hamilton 3-5

Governor

: and constitution 93-94

: in Federation Party manifesto 234

Governor-in-Council 89, 90

Govind, KN 235

Govind, RD 230

Gram Sangathan 109

Gram Sangathan Mahila Mandal 33

Gram Sudhar Sabha 33

Grant, John F 39, 40, 107

Great Council of Chiefs 38, 46, 48

: constitution $19654,185,204$

: opposition to franchise 95

: resolution against Indians 41

: strike 1960142

Greenwood, Anthony 196, 201, 202-203, 208

Griffith, EH 84

Gujarat 17-18

: free migrants in 1930s 36, 49 See also

Patidar migrants

: migrants from 1920s 37

Gujarat Mandal 38

Gujaratis: complaints against traders 22, 50,51

Gupta, Behari Lai 27

Gurd, Charles x, 245

Gurdayal 40

Hackett, Jack 118

Hammet, Sir Clifford x, xiv, 245

Hansen, GJT 124

Hardinge, Lord 11

Harvey, C 118

Hasan, Said 22, 69

: commission 194366

: Kisan Sangh 63

: nomination to Council 48

Herber, Bishop 120

Higher Education Mission 173

Hindu-Muslim divisions 37 
Hindus, intra-community divisions 37

Hohli, Harish 218

Housing Authority 167

Hurley, DP 167

Husain, Kifait 107

immigration restrictions 50, 89, 91

indebtedness 150

indentured immigration 5 See also indentured labour

indentured labour, contracts See girmit indentured labour, Indian 6, 7

indentured labour 1, 28, 141

independence 157, 158, 226, 235-236

: at constitutional conference 1965

197

: celebration of 242

: constitution 248

: Cook Islands 163, 185

: Fijian opposition to 184, 237

: in election 1966216

: in Federation Party manifesto 234

: Western Samoa 163, 185

India League $27-28$

India, Government of 6, 15, 21

: and Lord Salisbury's Despatch 99

: land lease pressure 47

: opposition to nomination 46

: support for common roll 42

: support for university 173

India, newspaper reports on 122

Indian Association of Fiji? 38, 44, 49

Indian Central War Committee 84

Indian Chamber of Commerce 38

Indian Civil Service 26-27

Indian enlistment, Second World War 82-85

Indian Labour Union 33

Indian National Congress 21, 105, 110

Indian Platoon 83

Indian Reform League 107

Indians Overseas Association 28

Indo-Fijians 15, 35-36

: Second World War 83-85

: elections 1963158
: intra-community divisions 37,41 , 49-50

: newspaper 120 See also Pacific

Review

: opposition to AD 111

: overseas attention 28,29

infrastructure, postwar reforms 86 International Sugar Agreement 131, 148

International University Council for

Higher Education Overseas 173

Iyer, Bhaskaran 106

izzat 21

Jackson, Sir Henry 5

Jagriti 33, 120

Jai Fiji 165

Jakeway, Sir Derek x, 23, 164, 178

: by-election 1967238

: constitutional conference 1964 187, 188

: on self-government 207

: opposition to common roll 194-195

: Wakaya Letter 186

Jayant, Albert 230

Johnson, WG (Tui) 102

Joseph, Andrew xviii, 31-32

Judd, J 84

Judicial and Legal Services Commission 199

Kadavr 19

Kalidas, Sundarji 106

Kamikamica, Josefata 121

Kanbi 19

Kapadia, RI 218

Karim, Abdul 39

Karsandas, Narotam 36

Kathiawar 36

Kermode, Sir Ronald xix, 69, 206

: and Denning arbitration 242, 243

: constitutional conference 1964188

: Eve Commission 145

Khan, Abdul Aziz 40

Khan, AG Sahu 40, 57-58

Khan, AR Sahu 82 
Khan, Liaquat Ali 27

Khan, Masud xix

Khan, Maulvi Mirza 13

Khan, Mohammed Tawahir 57, 61, 63

Khan, MT 218, 230

Kheda district 17, 18, 20-21

King, Irving 62, 69, 70

Kisan 15, 225

Kisan Mitra: constitutional conference 1964 165, 168. 188

Kisan Sangh 57, 58, 61-65, 106

: 24 July Agreement 139

: commission 194366

: Denning arbitration 242

: Eve report 151

: and Federation of Cane Growers

Associations 133

: elections 1963160

: Eve Commission 145

: opposition to Sugar Board 153

Kohli, Harish Chandra 160

Koloamatangi, Semisi 214

Koya, Moiddin 159

Koya, Shafiq 158-160

Koya, Siddiq xv, 176-177, 232, 242, 245

: and Federation Party 187

: as AD Patel's successor 249

: constitutional conference 1964188

: elections 1966218

: eulogy for AD xi-xii

: Eve Commission 145

: friction with AD 215-216

: growers contract 1960 133, 141

: meeting with Amery 144

: on death penalty 179

kshattriya 19

Kunzru, Pandit Hriday Nath 46

Kuppuswamy, Sadhu 53, 65, 112

labour agreement See girmit

labour, plantations 5

Lakshman, BD 70, 81, 218

: commission 194366

: Central Indian War Committee 82

: opposition to Sugar Board 153

: strike 1960 137, 143
Lalabalavu, Adi Litia 235

land

: Agricultural Landlord and Tenant

Bill 174-175

: at constitutional conference 1965

210

: Fijian 184, 185

: leases up to 193047

: reservations and displaced tenants

124-126

: reserves policy 174

: security of tenure 46-47

Langdale, CL 125

language education 107-108, 169-170

Laski, Harold 27

Lateef, Abdul 230

Latianara, Ratu Marika 139

legislation, minimum wage 87, 93

Legislative Council xv, 46, 85, 179, 189

: AD Patel's election to 81

: boycott 192939

: constitution revision 93-94

: constitution 1965 199-200

: constitutional debate 1967228

: elections 192939

: elections 193748

: elections 1963 158, 161

: Indian representation in 13, 15-16,

38,42

Leonidas 7

Letters Patent 1937 48, 93

Leva 19

Lewis, Justin 23, 174, 245

library service xviii, 32, 115-116, 168

: mobile 119

Lilac Theatre 193, 232

: conference 1938 46-47

lines $7,10,11$

liquor permit 107

liquor restrictions 82 See also prohibition

localisation xviii, 92-93, 234

Lodhia, HM xviii, 29, 106

London School of Economics, Indian students 27

Lord Salisbury 7 
Lord Salisbury's Despatch 6, 39, 99, 209

Luke, Sir Harry 56

MacFarlane, DM 145

Macmillan, AW 101, 126

Maddocks, Sir Kenneth xviii, xiv, 23 : strike 1960 135-137, 140

Madhavan, James 108, 168, 177, 215

: constitutional conference 1964188

: election 1963 158-160

: elections 1966218

: in Executive Council 165

Maha Sangh 65, 66

: and Federation of Cane Growers

Associations 133

: strike 194370

: Eve report 152

Maharaj, Badri 64

Maharaj, JP 36, 107

Maharaj, Pandit Badri 13

Maharaj, Ram Chandar 39

Maharaj, Sadanand 64

Major, RM 186

Mahila Mandal 109

Manilal 83

Mara, Adi Lala 230

Mara, Ratu Sir Kamisese 23, 177, 203, 227

: 24 July Agreement 139

: Alliance Party 207

: as Chief Minister 218

: as Member for Natural Resources

164

: as Prime Minister 242

: by-election 1967 236-237

: common name 223

: common roll 206

: constitutional conference 1964 188, 194

: constitutional conference 1965197

: constitutional debate 1967228

: constitutional talks 1969239

: eulogy for AD Patel xi, 248

: Geneva Conference on Sugar 231-

232

: in Pacific Review 121
: on death penalty 179,181

: on unions 219-220

: on independence 157, 184

: strike 1960143

: support for Britain 205

: Traffic Amendment Bill 162

: Wakaya Letter 186

Marks, Henry 41

Marsack, CC 226

Mataitini, Ratu Etuate 102

matanitu 2

mataqali 4,47

McGusty, Dr 79

Mela, Ratu 65

membership system 163-164, 183

: collective responsibility and 176-177

: end of 178-179

Menon, Krishna 27, 28

military training, Second World War 84

minimum wage legislation 87, 93

ministerial system 199, 227

Ministry of Food 67, 69, 70, 71

minority reports 177 See also Fiscal

Review Committee

Mission Library, Nadi 119

missionaries 2, 11

Mitchell, Sir Philip 78, 83

: and strike 194375

mobile library service 119

Moghuls 19

molasses 146, 152, 243

money lenders 50, 150

Morris, Sir Charles 173

Moynagh, Michael 145, 154-155

Mudaliar, Munsami 41, 44

Mukherji, Girin 82

Muni, Sadhu Basisth 14-15

Muslims: intra-community divisions 37,

51,111

: seat on Legislative Council 42, 43

Nadalo, Iskeli 139

Nadroga, Roko Tui 125

Nai Lalakai 191-192, 230

Naidu, MN 54, 65 
Naivalu, Serupepeli 231

Naqasima, Peniame 230

Narayan, Irene Jai 218

Narsey, Motiram 36

Narshi, Virji 36

National Archives of Fiji xix

National Congress of Fiji 194, 207

National Federation and Fiji Labour Party

Coalition 249

National Federation Party xx, 21, 241, 249

: and Pacific Review 120

: constitutional talks 1969239

National Service Tribunal 86-87

nationalisation of industries 223-224, 225

: in Federation Party manifesto 234

Native Land Trust 185

Native Land Trust Board 48, 125, 174,

184,221

: reservation 124

: resettlement of tenants 126

Native Land Trust Board Ordinance 210

Native Lands and Fisheries Commission 192

Native Lands Ordinance 1940 48, 124

native regulations 4

Nauru 224

Nav Yuvak Sabha 33, 109

Navsari 36

Nawai, Apolosi 4

Nehru, Jawaharlal 21, 105

Nehru, Motilal 26

newspapers, Indian 120

nominated members system 189, 199

nomination system $42-43,44-45$

O'Brien, Sir George 5

Ocean Island 224-225

Pacific Islands Monthly xiv

Pacific Review 33, 120-121, 234

: Fijian version 122-123

: political and social commentary 123-

124

: United Nations General Assembly

Committee on Decolonisation 195
Pacific War 65 See also Second World War

Parke, Aubrey xix, 166

Patel, Amita xvii, 105

Patel, Appabhai Lalubhai 20, 30, 36

Patel, Appabhai 51, 66

Patel, Atul xi, 105

Patel, CA 218

Patel, Chimanbhai 36

Patel, Dahyabhai 24, 29-30

Patel, Dhimant xi, 105

Patel, Haribai 23-25

Patel, HM 27

Patel, Ishwarbhai 24

Patel, Jayanti xix

Patel, Leela xviii

Patel, Manubhai 24

Patel, Margaret xix

Patel, Pratibha 105, 245-246

Patel, Raojibhai 24

Patel, RD xviii, 218

Patel, Shivabhai Bhailalbhai 20, 29, 51, 159

: AD Patel's detaining order 68

: early influence on Indo-Fijian

politics 38

: Fletcher meeting 1929 39-40

: Kisan Sangh 63

: libraries 115

: relationship with AD 32

: strike 194374

: strike 1960 141, 143

Patel, Surajben 24

Patel, Vallabhbhai 26

Patel, Vallabhbhai Jhaverbhai 17, 21

Patel, Vasantika xviii, 105

Patel, Vithalbhai 26

Patel, Vithalbhai Jhaverbhai 21

Patidar 19-20, 21, 30

: migrants 36-37

pay, indentured labour 7

Pearson, JR 16

penalties, in contracts 8,133

Penang Sugar Mill 59

pension, old age 234

phosphate industry 224

Pillay, MK xix, 159 
Pillay, MV 194, 230, 236

plantation economy 5

plantation work 10

Polak, Henry Saloman Leon 28, 29, 44

Police Services Commission 199

political leaders, early Indian 13

political parties 207

population $12,14,35$

postwar reforms $85-86$

Potts, EA 125

Potts, JC 139

Prarthana Sabha 106

Prasad, Ajodhya 33, 57, 61, 63, 106, 204

: 24 July Agreement 137

: elections 1966218

Prasad, Andrew Gaya 218, 230

Prasad, Durga 40

Price Stabilisation Fund 125

Prisons Service 167

prohibition debate 106-107

Public Relations Office 193

Public Service Commission 199

Punjabis 36, 64

Queen Victoria School 117

quotas, sugar 131

Rabukawaqa, Josua 204-205

race relations: and strike 1959129

racial discrimination 82

racialism 249

Ragg, Aime 93-94

: motion 1946 101-102, 104

: motion for extended Council 1948

96-97, 98

: repatriation of Indians 101

: resettlement 126

Ragg, Hugh 98

Raghvanand, B 82

Rahiman 40

Raju, Venkatpati 15

Ramakrishna Mission 33, 34, 54, 116-117

: adult education 119

: amalgamation attempt 1950 112-113

: university 173
Ramakrishna, Sri 53

Ramakrishnan, N 56, 58, 82

Ramakrishnan: Central Indian War

Committee 82

Ramjan, Ilahi 40

Ramrakha, Karam xix, 31, 218, 242, 245

Rao, Kodanda 38

rations, indentured labour 7

Ravai, Joeli 98

Raza, Hasan 43

Reay, Stuart 86

Reddy, Jai Ram xx, 32, 114, 118, 249

Reddy, KS 112, 194, 230, 239

Regan, RL 218

Reid, AC 186

Rennie, Frank 236

reservation, of Fijian land 124-126, 174

Resettlement Committee 125-126

resident, definition of 90

Residential and War Tax Bill amendment 87-89

residential tax See taxation: residential $\operatorname{tax}$

Rewa 2

Rice, Philip 105

Richards, Sir Arthur 55

Robinson, Sir Hercules 2, 3

Robson, RW xiv, 126

Rodger, JG 166-167, 217

Rotuman Association 207

Rudrananda, Swami xix, 33-34, 56, 106, 112

: detaining order 1943 67-68

: elections 1963159

: Maha Sangh 65

: on Kisan Sangh 64

: Ramakrishna Mission 116-117

: strike 194374

: university 173

Sagayam, Deva 39

Saheb, Shaukat Ali 230

Samujh, Ratu Ram 40

Sanadhya, Pandit Totaram 13

Sanadhya, Totaram 28 
Sanatanis 37

Sanders, Sir Arthur 226

Sanders, Sir Robert xv

Sangam 52-53, 54-55, 112-113

: and Kisan Sangh 64

: schools 56, 106

Sapru, PN 27

Sarada Sangam Press 120

Sarativau, S 171

Saulekaleka, Viliame 235

Savu, Viliame 222

schools, integration of 170-171

Scientific Investigation Committee 77

Scott, Maurice 91, 98

Scott, Sir Henry 69, 70

Second World War 81-85

secondary schools 117

Secretary for Fijian Affairs and Local

Government 164

Secretary for Fijian Affairs 199

Secretary of Indian Affairs 16

Secretary of Native Affairs 47

self-government 231, 189

: constitutional conference 1965 197,

198-199

: post-elections 1966218

Sen, BR 27

Seymour, Patricia Catherall 30-31, 51

Shah, Chirag Ali 164, 177, 215

: constitutional conference 1964188

: elections 1966218

Shah, Saiyyid Latif 57

Shantiniketan 31

Sharma, Deo 160, 161

Sharma, DS 137

Sharma, Harish 231

Sharma, Ram Tulsi 111

Sharma, RO 106

Sharma, Tulsi Ram 33, 106, 125, 159

: and Maha Sangh 65

: Central Indian War Committee 82

Shepherd enquiry xiv, 76-78

Shepherd, Lord 152

Sikh Gurudwara Committee 107

Sikivou, Alipate 237
Sikivou Semesa 177, 180, 186, 189

: and AD Patel 183

: constitutional conference 1964188

: on ALT bill 176

Silsoe, Lord See Eve, Sir Malcolm

Trustram

Singh, Babu Mangal 13

Singh, Chandrasenan Chattur 49, 51, 63,

83

: and Kisan Sangh 64

: election defeat 194781

Singh, CP 183, 204

: death penalty 179

: National Provident Fund 168-169

Singh, H Sahodar 82

Singh, James Shankar 160, 218

Singh, Jaswant 218

Singh, KB 41, 218

: Central Indian War Committee 82

: nomination to Council 48

: support for nomination system 42 ,

43-44

Singh, Mahadev 161

Singh, P Anand 49-50

Singh, Padri Mehar 5, 66

Singh, Parmanand 39, 40, 49

Singh, Phuman 107

Singh, Ramjati 218

Singh, Sir Vijay R xiv-xv, 230

: 24 July Agreement 137, 139

: constitutional debate 1967228

: constitutional talks 1969239

: growers contract 1960133

: strike 1960 137, 143

: tribute to AD 248

Singh, Spuran 40

Singh, Udrek 109

smallholder system 59

social security 93, 168

South Indians 22, 52, 56, 83

: and Kisan Sangh 64

: language education 108

: opposition to AD Patel 112

South Pacific Commission 119

South Pacific Sugar Mills Ltd 152 
Southern Cane Growers Association 33

Spate report 184

Sri Vivekananda High School 33, 116-

117, 118-119

Street Commission 249

Street, Harry 249

strike 1943 22, 33, 66-67

: AD Patel's role in $69,71-72,78-79$

: agreement 74-75

: government response 70-72, 76

: growers' demands 72

strike 1959129

strike 1960 22, 129-130, 136-137, 142-143

: 24 July Agreement 140

: commission of inquiry See Eve

Commission

: contract negotiation 133-136

: government proposal 1 September

141-142

subdivision See smallholder system

Sugar Advisory Board 225-226, 233

Sugar Board 77, 130, 153

: CSR opposition 78

: Eve Commission 148, 151

sugar cane price: agreement 1943 73-75

sugar industry 5, 58-60

: 1960 commission of inquiry See Eve

Commission

: labour 59

: late 1930s to early 1940s 65

: late 1960s 223-224, 225

: molasses pricing 146-147, 152

: new contract 1970225

: production costs 149-150

: quotas 131, 148

: Shepherd enquiry 76-77

: strike 1943 73-74

: strike 1960 130-131

: tenants 175-176

Sugar Industry Control Bill 226

Sugar Price Stabilisation Fund 148-149, 151

Sukuna, Ratu Sir Lala xiii, xvi, 48, 221 ,

242

: opposition to localisation 82

: strike 1943 74-76
Sumeran, Pandit Ram 106

Surat 36

Suva Grammar 117, 170-171

Swayam Sevak Dal 33, 109

Tagore, Rabindranath 27

Tagore, Satyendra Nath 27

task work 8, 10

taxation

: basic tax 177

: Fijian and non-Fijian 89

: Residential and War Tax Bill

amendment 87-89

: residential tax 88-89

taxi industry 162-163

The Indian Settler 13

Then India Sanmarga Ikya Sangam 12, 38

Thompson, Ian 176

Thurn, Sir Everard im 5

Toganivalu, David 239

Toganivalu, Ratu David xi, 230, 235

Toganivalu, Ratu George 98

Toganivalu, Ratu Julian 230, 234

Toganivalu, Ratu William xv, 242

: on AD Patel in Council 161

: by-election 1967237

Tongan community, Fiji 2

tonnage quota 132, 133, 136, 152

: in 24 July Agreement 138

Tora, Apisai 129, 230, 231

: constitutional conference 1964188

: resettlement of Indians 196

trade union legislation 61,60

Traffic Amendment Bill 162

Transport Control Board 162, 163

Tuinaceva, Setareki xix

Tuisawau, Ratu George 91, 98

Tuivaga, Timoci 121

unemployment benefit 234

unions 219, 234

United Nations General Assembly

Committee on Decolonisation 195-196

United Nations: resolution against colonialism 158

United Provinces 8 
universal franchise 95, 158, 199 See also common roll

university 172-173

University College of the South Pacific 119

University of the South Pacific xviii, 119, 173

University Tutorial College 173

Vacuum Oil 129

Vaishanavism 25

Vajpai, VP 218

Vakalelewa ni Pasifika 122-123 See also

Pacific Review

Vancouver Sugar Company 12

Vanualevu Farmers' Union 133

Veresikete, Ratu Mosese 230-231, 234, 235

Vishal Sangh 133

Vivekananda, Swami 53, 54

Volagauna 230

: Fijian land ownership 184-185

: independence 157

: resettlement of Indians 196

Vuakatagane, Emosi 230

Vuiyasawa, Ratu Tiale xv, 98

Vunivalu, Ravuama: in Pacific Review $118,121,143.186$

Waiz, Samuel Alfred 111

Wakaya Letter 185-186

Waqanivavalagi, Sakiasi 223-224, 237

Western Regional Library 119

Western Samoa: independence 163, 185

Weston, QVL xii, 141

Wheatley, IS 145

White, Eireen 192-193, 196

Whitehead, CE 125

Wholesale and Retail General Workers Union strike 1959129

Working Committee on Landlord and

Tenant Matters 245

Yee, HW 239

Young India Society 49 


\section{AD Patel Sub-index}

Agreement 24 July 140

Agricultural Landlord and Tenant Bill 175-176

Albert Park speech 1965200

anti-colonialism $\mathrm{xvi}, 123-124,127$

basic tax, opposition to 177

by-election 1967 229-230, 233, 236

Central Indian War Committee 82

commission into cane growing 1943 66, 73-74

commissions of inquiry, views on 135

common name 222-223

common roll, views on 93, 205-206

: at constitutional conference 1964

189-191, 192

communal voting 206-207

constitution 1965, opposition to 226-228

constitutional conference 1964 187-188,

194

constitutional conference 1965 197-199,

201-202, 204-205

constitutional debate 1948 98-99, 100

constitutional debate 1967229

cultural background 17-21

death penalty, views on 180-181

decision to go to Fiji 30

defence of Indian culture 111

delegate to Indian National Congress 105

Denning arbitration 242-243

Deo, Vishnu, early relationship with 3233

Deo, Vishnu, rift with 106-107, 108

Deoki, Andrew 164

detaining order 1943 67-69

development, views on 169 early influence on Indo-Fijian politics 38 editorials in Pacific Review 123-124

education of 25-26

education, views on 116-117, 169, 171,

172

election defeats 1950, 1953106

election to Legislative Council 81

election 192939

election 1937 48-49

election 1963 158-161

election 1966 216-218

Eve Commission, submission to 145-151

Eve Commission report, in 152-153

Eve Commission report, on 154

Executive Council candidature 108-109

extra-marital affairs 31

family background 23-24, 25

family trip 1952105

farmer's advocate 22

Federation Party manifesto 233-234, 235

Fijian administration, on 220-222

Fijian welfare 128

first political campaign 38-39

foreign capital, views on 217-218

Geneva Conference on Sugar 231-232

Governor-in-Council, on 90

growers contract 1960 133, 134-136, 140-

141

Gujarati opposition 51

health 214

heart attack 245

immigration control, postwar 89-91 immigration restrictions, opposition to 50-51

independence, views on 157-158, 236

Indian National Congress 110

Indian nationalist movement 21

inspection of CSR's accounts 1943 69-70

integration of schools 170-172

Kisan Sangh 57-58, 63, 64 
Koya, Siddiq, relationship with 159, 215216

Kuppuswamy 53-54

labour relations 86,87

land exploitation 126-127

landlord, as 22-23

language education, on 107-108

languages, on 170

Leader of the Opposition 218

legal practice in Suva 31

Legislative Council, activities in 161-162

Legislative Council, shortcomings of 9495

letter to Greenwood 202, 208-211

localisation, support for 92-93

London School of Economics 27-28, 29

marriage to Leela Ben 105

Member for Social Services 164-169

membership system, on 166

Muslim opposition 51

nationalisation of industries 223-224, 225

New Years address 1969241

nomination system, opposition to 44-45

nuclear tests 121-122

Open Letter 194367

Pacific Review 120-121

Patel, Appabhai 51

Patel, SB, relationship with 32

Patricia Seymour, relationship with 30-31

personal interests 23

political opposition 110-111

professional life 1950s 105-106

public libraries, support for 115-116

qualification as barrister 29

Ragg's motion 1948 98-99, 102-104

Ramakrishna Mission 116

reading 114-115

reputation as lawyer 213-214 resettlement of farmers 124-125, 126

Residential and War Tax Bill amendment 88

Sangam 52, 53-54, 55, 106

Shepherd enquiry 77

social security 86,93

speeches in 1950s 113-114

strike $194367,76,78-79$

strike 1960 130-132, 136-137, 143

Sugar Industry Control Bill 226

Swami Avinasananda 54

Swami Rudrananda, relationship with

33-34

talent as advocate $31-32$

tenure in Council 95

Traffic Amendment Bill 162

tribute to Gandhi 1969 246-247

unions 219

United Nations General Assembly

Committee on Decolonisation 195-196

universal franchise, support for 95

university proposal 119, 172-173

vision for reforms 85-86

Wakaya Letter 186 
